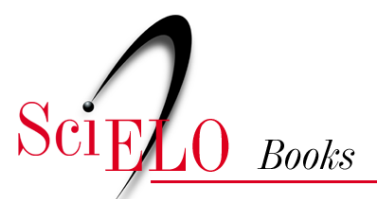

\title{
Álcool e outras drogas diálogos sobre um mal-estar contemporâneo
}

\author{
Sergio Alarcon \\ Marco Aurélio Soares Jorge \\ (orgs.)
}

\section{SciELO Books / SciELO Livros / SciELO Libros}

ALARCON, S., and JORGE, MAS., comps. Álcool e outras drogas: diálogos sobre um mal-estar contemporâneo [online]. Rio de Janeiro: Editora FIOCRUZ, 2012, 346 p. ISBN: 978-85-7541-539-9. https://doi.org/10.7476/9788575415399.

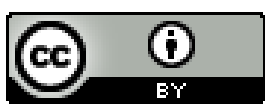

All the contents of this work, except where otherwise noted, is licensed under a Creative Commons Attribution 4.0 International license.

Todo o conteúdo deste trabalho, exceto quando houver ressalva, é publicado sob a licença Creative Commons Atribição 4.0. 


\section{ÁLCOOL e Outras Drogas}

diálogos sobre um mal-estar contemporâneo 


\section{Fundação Oswaldo Cruz - Fiocruz}

PRESIDENTE

Paulo Gadelha

VICE-PRESIDENTE DE ENSINO, INFORMAÇÃO E COMUNICAÇÃO

Nísia Trindade Lima

\section{Editora Fiocruz}

DIRETORA

Nísia Trindade Lima

EDITOR EXECUTIVO

João Carlos Canossa Mendes

EDITORES CIENTÍFICOS

Gilberto Hochman

Ricardo Ventura Santos

CONSELHO EDITORIAL

Ana Lucia Teles Rabello

Armando de Oliveira Schubach

Carlos E. A. Coimbra Jr.

Gerson Oliveira Penna

Joseli Lannes Vieira

Ligia Vieira da Silva

Maria Cecília de Souza Minayo 
Copyright (c) 2012 dos autores

Todos os direitos desta edição reservados à

FUNDAÇÃO OSWALDO CRUZ / EDITORA

A Editora não se responsabiliza pela continuidade ou atualidade dos sites citados neste livro, assim como não garante que os conteúdos nesses endereços estejam válidos e corretos.

Capa,Projeto gráfico e Editoração eletrônica Robson Lima - Obra Completa Comunicação

Supervisão editorial

Janaina de Souza Silva

Revisão e copidesque

Irene Quintáns Liñares

Revisão técnica

Francisco Inácio Bastos

Catalogação na fonte

Instituto de Comunicação e Informação Científica e Tecnológica em Saúde/Fiocruz

Biblioteca de Saúde Pública

C351 Alarcon, Sergio (Org.)

Álcool e outras drogas: diálogos sobre um mal-estar contemporâneo./ organizado por Sergio Alarcon e Marco Aurélio Soares Jorge. — Rio de Janeiro: Editora Fiocruz, 2012.

346p. : il. ; tab. ; graf.

ISBN: 978-85-7541-226-8

1. Drogas Ilícitas. 2. Alcoolismo. 3. Políticas Públicas.. 4. Política Social. 5. Promoção da Saúde. 6. Saúde Mental. I. Jorge, Marco Aurélio Soares (Org.). II. Título.

CDD - 22.ed. - 362.29

2012

EDITORA FIOCRUZ

Av. Brasil, 4036 - Térreo - sala 112 - Manguinhos

21040-361 - Rio de Janeiro - RJ

Tels: (21) 3882-9039 e 3882-9041

Telefax: (21) 3882-9006

e-mail:editora@fiocruz.br

www.fiocruz.br/editora 


\section{Autores}

Alexandre Magno Teixeira de Carvalho I Psicólogo. Doutor em Ciências/Saúde Pública pela Escola Nacional de Saúde Pública Sergio Arouca da Fundação Oswaldo Cruz (Ensp/ Fiocruz). Professor adjunto do Departamento de Saúde Coletiva da Universidade Federal do Estado do Rio de Janeiro (DSC/UniRio) e coordenador do grupo de pesquisa Ciências Humanas, Saúde e Sociedade.

Carolina Fernandes Pombo-de-Barros I Psicóloga. Mestra em Saúde Pública pela Escola Nacional de Saúde Pública Sergio Arouca da Fundação Oswaldo Cruz (Ensp/Fiocruz). Pesquisadora colaboradora da Universidade Aberta da Terceira Idade da Universidade do Estado do Rio de Janeiro (Unati/Uerj).

CRistina Maria Douat Loyola I Enfermeira. Doutora em Saúde Coletiva pela Universidade do Estado do Rio de Janeiro (Uerj), pós-doutora pela Universidade de Toronto, Canadá.Professora titular da Universidade Federal do Rio de Janeiro (UFRJ), coordenadora do Laboratório de Projetos e Pesquisa em Psiquiatria e Saúde Mental (Lappepsm) da UFRJ, consultora da Coordenação de Saúde Mental do Ministério da Saúde (SAS/MS) e secretária adjunta de ações básicas de saúde da Secretaria de Estado da Saúde do Maranhão (SES/MA).

Elize Massard Fonseca I Psicóloga. Doutora em Saúde Pública pela Escola Nacional de Saúde Pública Sergio Arouca da Fundação Oswaldo Cruz (Ensp/Fiocruz), doutora em Política Social pela Universidade de Edimburgo, Reino Unido, pós-doutoranda no Centro de Estudos da Metrópole do Centro Brasileiro de Análise e Planejamento (CEM/Cebrap). Bolsista da Fundação de Amparo à Pesquisa do Estado de São Paulo (Fapesp).

Fabíola Espolador Ramalho I Assistente Social. Especialista em: Terapia de Família pela Universidade Cândido Mendes (Ucam); Violência Doméstica pela Universidade de São Paulo (USP); Segurança Pública, Cultura e Cidadania pela Universidade Federal do Rio de Janeiro (UFRJ). Assistente social do Sistema Penitenciário do estado do Rio de Janeiro, atuando como perita em crimes sexuais e urbanos e assistente social do Caps II de Seropédica.

Fátima Guedes I Licenciada em Medicina. Mestra em Patologia Experimental pela Universidade Federal Fluminense (UFF), doutora em Ciências Médicas pela Universidade do Porto - Portugal. Professora adjunta IV da UFF, professora associada da Universidade Fernando 
Pessoa - Porto e médica da Unidade de Alcoologia do Instituto da Droga e da Toxicodependência (IDT), Portugal.

Francisco InÁcio Bastos I Médico. Doutor em Saúde Pública pela Escola Nacional de Saúde Pública da Fundação Oswaldo Cruz (Ensp/Fiocruz). Pesquisador titular do Centro de Informações Científicas e Tecnológicas (Icict) da Fiocruz.

JuPIARA dos SANTOS I Assistente Social.Especialista em Saúde Mental pela Escola Nacional de Saúde Pública Sergio Arouca da Fundação Oswaldo Cruz (Ensp/Fiocruz). Coordenadora Municipal de Saúde Mental de Seropédica.

Jurema Alves Pereira I Assistente Social. Especialista em Serviço Social e Saúde pela Faculdade de Serviço Social da Universidade do Estado do Rio de Janeiro (FSS/Uerj), mestra em Tecnologia Educacional nas Ciências da Saúde pelo Núcleo de Tecnologia Educacional para a Saúde da Universidade Federal do Rio de Janeiro (Nutes/UFRJ). Assistente social da FSS/Uerj, professora do Curso de Serviço Social da Universidade Castelo Branco (UCB) e ex-integrante da equipe técnica do Caps ad Vanderlei Marins.

Lannia SimÃo Bellizzı I Psicóloga. Especialista em Assistência a Usuários de Álcool e Outras Drogas pelo Programa de Estudos e Assistência ao Uso Indevido de Drogas do Instituto de Psiquiatria da Universidade Federal do Rio de Janeiro (Projad/Ipub/UFRJ). Ex-integrante da equipe técnica do Caps adVanderlei Marins e psicóloga do Caps ad de Resende.

Luciana Caliman I Psicóloga. Pós-doutora em Psicologia pelo Instituto de Psicologia da Universidade Federal do Rio de Janeiro (UFRJ). Professora assistente de Psicologia da Universidade Federal do Espírito Santo (Ufes) e do Programa de Pós-Graduação em Psicologia Institucional do Departamento de Psicologia (PPGPSI) da Ufesc, pesquisadora do Projeto International "Brainhood - the Cerebral Subject" - Brasil/Alemanha.

Luiz Carlos Felício I Psicólogo. Membro do Colegiado Gestor do Programa Municipal de Saúde Mental de Paracambi, coordenador do Caps ad de São Gonçalo e supervisor clínico institucional do Caps ad de Três Rios.

Luíza GARNElo I Médica-sanitarista. Doutora em Antropologia pela Universidade Estadual de Campinas (Unicamp). Pesquisadora do Instituto Leônidas e Maria Deane da Fundação Oswaldo Cruz (ILMD/Fiocruz).

Márcia Anselmo Belchior I Psicóloga. Especialista em Psicopedagogia pela Fundação Técnico Educacional Souza Marques (FTESM). Diretora técnica do ambulatório de saúde mental José Miller em Nova Iguaçu, colaboradora na implantação e coordenadora do Caps ad Vanderlei Marins e psicóloga do Centro Especializado em Doenças Digestivas e do Fígado (Cedifi). 
Marco Aurélio Soares Jorge (Organizador) I Médico psiquiatra. Doutor em Saúde Púbica pela Escola Nacional de Saúde Pública Sergio Arouca da Fundação Oswaldo Cruz (Ensp/Fiocruz). Pesquisador da Escola Politécnica de Saúde Joaquim Venâncio (EPSJV) da Fiocruz e membro da equipe clínico-jurídica do Grupo Tortura Nunca Mais-RJ.

Maria Angélica Salgado Ferraz I Psicóloga. Especialização em: Psicopedagogia pela Universidade Severino Sombra (USS) e Álcool e Outras Drogas pela Universidade Federal de São Paulo (Unifesp). Psicóloga do Caps ad de Paracambi e auriculopunturista.

Marise de Leão RamôA I Psicóloga. Doutora em Psicologia Clínica pela Pontifícia Universidade Católica do Rio de Janeiro (PUC-Rio).Supervisora clínico-institucional do Caps ad de Paracambi pelo Ministério da Saúde até fevereiro de 2012, supervisora do Caps ad de Resende e diretora do Caps ad Mané Garrincha.

Maristela Monteiro I Médica pela Escola Paulista de Medicina da Universidade Federal de São Paulo (EPM/Unifesp). Doutora em Psicofarmacologia e pós-doutora pela Universidade da California (UC), San Diego/EUA. Assessora Regional sobre Abuso de Álcool e Outras Drogas da Organização Pan-Americana da Saúde (Opas).

Maximiliano Loiola Ponte de Souza I Médico psiquiatra. Doutor em Ciências pelo Instituto Fernandes Figueira da Fundação Oswaldo Cruz (IFF/Fiocruz). Pesquisador adjunto do Instituto Leônidas e Maria Deane (ILMD) da Fiocruz, atuando na área de pesquisa em saúde indígena.

Mônica MaLTA I Psicóloga. Mestra em Epidemiologia pela Johns Hopkins Bloomberg School of Public Health, Estados Unidos. Doutora em Saúde Pública pela Escola Nacional de Saúde Pública Sergio Arouca da Fundação Oswaldo Cruz (Ensp/Fiocruz). Pesquisadora do Departamento de Ciências Sociais (DCS) da Ensp/Fiocruz, pesquisadora visitante da Johns Hopkins Bloomberg School of Public Health e membro do corpo editorial do periódico The International Journal on Drug Policy.

Nina Isabel Soalheiro Prata I Terapeuta Ocupacional. Doutora em Saúde Pública pela Escola Nacional de Saúde Pública Sergio Arouca da Fundação Oswaldo Cruz (Ensp/Fiocruz). Pesquisadora do Laboratório de Educação Profissional em Atenção em Saúde da Escola Politécnica em Saúde Joaquim Venâncio (Laborat/EPSJV) da Fiocruz.

Pilar Rodriguez Belmonte I Psicóloga. Doutora em História da Saúde pela Casa Oswaldo Cruz da Fundação Oswaldo Cruz (COC/Fiocruz). Coordenadora de Saúde Mental da Secretaria Municipal de Saúde e Defesa Civil do Estado do Rio de Janeiro (SMSDC-RJ).

Rita de Cássia Cavalcante Lima I Assistente Social. Doutora em Serviço Social pela Universidade Federal do Rio de Janeiro (UFRJ). Professora adjunta da Escola de Serviço Social da UFRJ. 
RodRIGO Luiz Lessa I Enfermeiro. Especialista em Saúde Mental e Psiquiatria pelo Hospital Escola São Francisco de Assis da Universidade Federal do Rio de Janeiro (Hesfa/UFRJ). Enfermeiro do Caps ad de Paracambi.

Sergio Alarcon (Organizador) I Bacharel em filosofia e médico psiquiatra. Doutor em Ciências/Saúde Pública pela Escola Nacional de Saúde Pública Sergio Arouca da Fundação Oswaldo Cruz (Ensp/Fiocruz). Professor do Curso de Especialização em Bioética do Programa de Educação a Distância (EAD/Ensp/Fiocruz) e assessor de saúde mental da Secretaria Municipal de Saúde e Defesa Civil do Estado do Rio de Janeiro (SMSDC-RJ) para o eixo Álcool e Outras Drogas.

Simone Pinheiro da Silva I Nutricionista e Enfermeira. Especialista em Saúde Mental e Atenção Psicossocial pela Escola Nacional de Saúde Pública Sergio Arouca da Fundação Oswaldo Cruz (Ensp/Fiocruz). Enfermeira do Caps III João Ferreira da Secretaria Municipal de Saúde e Defesa Civil do Estado do Rio de Janeiro (SMSDC-RJ).

Tatiana Rangel Reis I Assistente Social. Doutora em Serviço Social pela Universidade Federal do Rio de Janeiro (UFRJ). Professora adjunta da Escola de Serviço Social da Universidade Federal Fluminense (UFF).

Verônica Silva Fernandez I Nutricionista. Mestra em Saúde Pública pela Escola Nacional de Saúde Pública Sergio Arouca da Fundação Oswaldo Cruz (Ensp/Fiocruz). Professora assistente do Departamento de Planejamento em Saúde do Instituto de Saúde da Comunidade da Universidade Federal Fluminense (UFF). 


\section{SUMÁRIO}

$\begin{array}{ll}\text { Apresentação } & 11\end{array}$

1. Os Tratados Internacionais Antidrogas e o Brasil: 15 políticas, desafios e perspectivas

Elize Massard Fonseca \& Francisco Inácio Bastos

2. A Síndrome de Elêusis: considerações sobre as políticas públicas no campo de atenção ao usuário de álcool e outras drogas Sergio Alarcon

3. O Campo de Atenção ao Dependente Químico Sergio Alarcon, Pilar Rodriguez Belmonte \& Marco Aurélio Soares Jorge

4. Higiene e Eugenia: brevíssima genealogia da trama discursiva antialcoólica no Brasil Alexandre Magno Teixeira de Carvalho

5. Drogas Psicoativas: classificação e bulário das principais drogas de abuso Sergio Alarcon

6. Critérios para o Diagnóstico de Dependência Química Sergio Alarcon

7. Rastreamento e Abordagem Terapêutica de Doentes com Problemas Relacionados ao Álcool

Fátima Guedes

8. Políticas Sociais Públicas e a Centralidade da Família: implicações para a assistência na área de álcool e outras drogas Rita de Cássia Cavalcante Lima

9. Empoderamento e Grupos de Mútua Ajuda 
10. Reflexões sobre o Campo da Psicologia e o Uso Abusivo de Drogas

Carolina Fernandes Pombo-de-Barros \& Verônica Silva Fernandez

11. Drogas de Desempenho: a Ritalina e o transtorno do déficit de atenção/hiperatividade (TDAH)

Luciana Caliman

12. Manejo do Paciente Usuário de Drogas Vivendo com HIV/Aids Mônica Malta, Francisco Inácio Bastos \& Maristela Monteiro

13. Relativismo Cultural e Uso de Álcool: contribuições

a partir do campo da saúde indígena

Maximiliano Loiola Ponte de Souza \& Luíza Garnelo

14. Surtado ou Assustado? Algumas considerações sobre violência e cuidado no contexto dos serviços territoriais de saúde mental e atenção psicossocial Nina Isabel Soalheiro Prata

15. Integralidade e Interdisciplinaridade: o movimento de desconstrução da cultura asilar a partir da experiência do Caps ad de Paracambi

Marise de Leão Ramôa, Luiz Carlos Felício, Maria Angélica Salgado Ferraz \& Rodrigo Luiz Lessa

16. Caps ad de Nova Iguaçu: a história de implantação de uma política de álcool e outras drogas

Simone Pinheiro da Silva, Lannia Simão Bellizzi, Jurema Alves Pereira, Márcia Anselmo Belchior \& Cristina Maria Douat Loyola

Sergio Alarcon, Jupiara dos Santos, Fabíola Espolador Ramalho, Márcia Anselmo Belchior, Jurema Alves Pereira, Simone Pinheiro da Silva, Lannia Simão Bellizzi \& Cristina Maria Douat Loyola 


\section{Apresentação}

Este livro é resultado das atividades docentes no Curso de Atualização para a Atenção ao Uso Abusivo de Álcool e Outras Drogas, oferecido anualmente, desde 2006, pela Escola Politécnica de Saúde Joaquim Venâncio da Fundação Oswaldo Cruz (EPSJV/Fiocruz). Fruto de um trabalho de pesquisa e estudos, além de supervisões e capacitações de equipes de saúde mental, realizadas em diversas cidades do estado do Rio de Janeiro pelos profissionais ligados ao Grupo de Trabalho em Saúde Mental do Laboratório de Educação Profissional em Atenção em Saúde (Laborat) da EPSJV/Fiocruz, o curso tem como objetivo democratizar, para os trabalhadores da saúde, em geral, e da saúde mental, em particular, o acesso às polêmicas e aos dilemas que constituem o campo álcool e outras drogas (AD) no Brasil.

Grande parte do corpo docente do curso contribuiu para a elaboração dos capítulos, e também buscamos testemunhos importantes daqueles que estão na linha de frente das práticas de atenção e cuidado ao usuário de AD e seus familiares (e que são a razão de ser do curso). Assim, o que o leitor tem diante de si são textos nascidos da percepção de que era necessário oferecer de modo mais ampliado e sistematizado um conjunto de reflexões e experiências desenvolvidas nas dinâmicas das salas de aula. Aquilo que inicialmente era apenas uma compilação de textos de apoio para o curso de atualização adquiriu maior robustez, ampliando de modo significativo a investigação no que diz respeito ao universo de AD.

É sobretudo importante sublinhar que este livro, apesar de construído para os trabalhadores da saúde, pode ser lido por qualquer outra pessoa interessada pelo assunto, pois as reflexões aqui desenvolvidas estão adequadas ao momento atual no qual a discussão sobre o problema droga, tanto as lícitas quanto as ilícitas, transcende os debates dos especialistas da saúde ou da segurança pública e ganha importância dentro de outros campos do saber, como a economia, as ciências sociais, os estudos sobre violência e direitos humanos etc.

No decurso da leitura, será possível notar que os textos aqui reunidos são heterogêneos, mas possuem algo em comum quando avaliados em conjunto: 
buscam, antes que respostas rápidas categóricas, oferecer ao leitor modos de problematizar o fenômeno complexo das drogas.

É sob um acordo tácito, marcado pelo signo da interrogação contido no diálogo entre diferentes autores que o livro se organizou como uma espécie de mapa, coerente em sua geografia, onde se encontram orientações, direções para pensar o mal-estar atual dos discursos e das práticas sobre as drogas e seus usuários. Encontramos, assim, nesta coletânea, pari passu a esses debates ampliados, análises políticas, filosóficas, antropológicas e assistenciais, que criam uma rede de significações, por vezes inusitadas do ponto de vista do senso comum para o 'problema-droga'.

No capítulo 1, de Elize Massard Fonseca e Francisco Inácio Bastos, são tecidas considerações a respeito da emergência das políticas proibicionistas no mundo e sua influência para a construção das políticas brasileiras sobre drogas. Na trilha desse tema, Sergio Alarcon formula, em "A síndrome de Elêusis", um breve ensaio sobre as contradições nas políticas públicas de atenção aos usuários de $\mathrm{AD}$, enfatizando as escolhas ético-políticas possíveis, geradas pela polissemia que o termo técnico 'redução de danos' adquire em sua história.

No capítulo 3, intitulado "O campo de atenção ao dependente químico", Sergio Alarcon, Pilar Rodriguez Belmonte e Marco Aurélio Soares Jorge discutem os acordos e desacordos nos setores de segurança e de saúde, áreas públicas que se entrechocam no ponto tangencial das drogas.

Alexandre Magno Teixeira de Carvalho nos expõe, no capítulo 4, as tramas - em todos os sentidos do termo - demarcadas pelas relações entre higiene, eugenia, alcoolismo e capitalismo no Brasil.

Sergio Alarcon colabora ainda com dois capítulos, ambos voltados para auxiliar o leitor na compreensão da ideia do que seriam as drogas, na identificação daquelas mais comuns, abordando as questões do dia a dia da assistência. No capítulo 5 fala sobre a classificação e os tipos de drogas mais usadas para recreação e sobre o uso prejudicial; no capítulo 6, discorre a respeito dos critérios diagnósticos da dependência.

Relacionado a questões de tratamento, no capítulo 7, Fátima Guedes expõe um dos protocolos possíveis para o cuidado ao dependente de álcool. No capítulo seguinte, Rita de Cássia Cavalcante Lima apresenta a importância do acolhimento à família nos meandros dos tratamentos ofertados pela saúde pública. Já no capítulo 9, Tatiana Rangel Reis faz um estudo que nos abre a oportunidade para entender e utilizar, no sistema público de saúde, soluções nascidas como apoio social no âmbito privado das comunidades. 
No capítulo 10, Carolina Fernandes Pombo-de-Barros e Verônica Silva Fernandez descortinam o potencial da psicologia para o tratamento das farmacodependências. As autoras buscam, sobretudo, alertar sobre a importância de referências teórico-práticas que privilegiem pesquisas capazes de fazer convergir a formação da subjetividade no mundo moderno, as reformas sanitária e psiquiátrica, a promoção social da saúde e o uso de drogas psicotrópicas - convergência que é o grande desafio para a inserção proativa da psicologia nas políticas públicas específicas para a área, eticamente coerentes com a necessidade de construção de justiça social no nosso país.

No capítulo 11, Luciana Caliman discute como a recente conexão entre os estudos sobre a desordem da atenção e do controle do comportamento e a pesquisa cerebral fazem emergir a descoberta (ou invenção?) de patologias (no exemplo do texto, o chamado transtorno do déficit de atenção/hiperatividade - TDAH) que legitimam a medicina a prescrever as chamadas 'drogas de desempenho', como é o caso da Ritalina.

Mônica Malta, Francisco Inácio Bastos e Maristela Monteiro nos oferecem, no capítulo 12 , uma aula sobre o manejo de pacientes usuários de drogas vivendo com HIV/Aids.

Maximiliano Loiola Ponte de Souza e Luíza Garnelo fazem, ao longo do capítulo 13, um contraponto entre o 'beber como problema' em meio urbano e os modos de beber nas comunidades indígenas. A partir dessa polifonia antropológica, os autores propõem novas ações nos serviços na área de AD, enfatizando a importância da construção de uma lógica diagnóstica que pense o geral a partir do particular, e não o inverso, como é tradicional no ensino da clínica.

No capítulo 14, de Nina Isabel Soalheiro Prata, é exposta a vulnerabilidade das instituições de saúde mental à violência do entorno, o que aparenta ter relação direta não apenas com a guerra às drogas, mas também com a fragilidade na organização dos processos coletivos e com o abandono, pelas equipes dos serviços territoriais, da problematização dos laços sociais que se fazem a partir da convivência. Segundo a autora, "o modelo Caps/casa vem sucumbindo à complexidade da realidade urbana, da miséria e da cultura de rua, nos aproximando perigosamente da violência e do caos".

Na sequência, foi dada voz aos representantes das equipes de alguns serviços públicos de AD dos municípios do estado do Rio de Janeiro, cujos trabalhadores de alguma forma puderam se beneficiar com as aulas do curso de atualização. Obviamente, por uma questão de espaço, não foi possível reunir toda a gama de contribuições significativas disponíveis. 
Do Caps ad de Paracambi, Marise de Leão Ramôa, Luiz Carlos Felício, Maria Angélica Salgado Ferraz e Rodrigo Luiz Lessa discorrem, no capítulo 15, sobre como, a partir do trabalho territorial e interdisciplinar próprio aos centros de atenção psicossocial (Caps), é possível promover o desmonte da cultura asilar, ainda hegemônica quando se pensa em tratamento para usuários de AD.

Do Caps ad de Nova Iguaçu, Simone Pinheiro da Silva, Lannia Simão Bellizzi, Jurema Alves Pereira, Márcia Anselmo Belchior e Cristina Maria Douat Loyola descrevem, a partir do ponto de vista do trabalhador de saúde mental, as vicissitudes, possivelmente nada incomuns, para a implantação de um serviço antimanicomial voltado ao usuário de AD.

Por fim, no Anexo, escrito por diversos autores, é apresentada a sugestão de um instrumento diagnóstico interdisciplinar, baseado na ideia de que o diagnóstico do uso prejudicial de drogas não pode derivar apenas das observações parciais de uma profissão ou especialidade, mas conforme o conjunto irredutível de perspectivas envolvidas na atenção (incluindo a do próprio usuário), cujo sentido vai além da simples soma dessas visões.

Este livro é, em muitos aspectos, um esforço contra o tédio do chamado pensamento único, contra a banalidade das superstições, nas quais antigas políticas públicas, transformadas em modelos para o cuidado e o tratamento se repetem, sem cessar, nos vícios instituídos. Contudo, nossa sociedade, incluindo os dependentes, não consegue se livrar facilmente dessa visão 'viciada' e ainda não percebe toda a extensão dos prejuízos dos quais é vítima. Esperamos que a leitura desta obra possa oferecer ao menos momentos de maior lucidez.

Aproveitamos a oportunidade para agradecer àqueles sem os quais esta publicação seria impossível, a saber: à direção da EPSJV, a Francisco Inácio Bastos e a Pilar Rodriguez Belmonte, a Maria Eliana Labra, Fermin Roland Schramm, Janaína de Souza Silva e João Canossa.

Os organizadores 


\title{
Os Tratados Internacionais Antidrogas e o Brasil: políticas, desafios e perspectivas'
}

\author{
Elize Massard Fonseca \\ Francisco Inácio Bastos
}

O uso de substâncias psicoativas (como as bebidas alcoólicas e as substâncias que hoje denominamos drogas, como a tintura de ópio) é de conhecimento geral, ao que parece, desde a pré-história. Estados de embriaguez e outras formas de alteração da percepção e do comportamento não são exclusividade das sociedades humanas, pois diferentes animais ingerem, de forma proposital, frutos e raízes que alteram seus comportamentos (Jonas \& Jonas, 1980).

Há farta documentação referente ao consumo do ópio por parte dos antigos egípcios, gregos e romanos, com finalidade religiosa e recreativa (Duarte, 2005; Bellis, 1981). Os médicos romanos e árabes, e, séculos mais tarde, os ingleses, utilizavam amplamente a tintura de ópio (extraída da papoula) para tratar afecções, como as disenterias e outras síndromes diarreicas (no que não diferem em nada de nós, que utilizamos até hoje produtos à base da tintura de ópio, como o elixir paregórico, com a mesma finalidade).

\footnotetext{
1 A revisão de literatura deste estudo foi realizada na biblioteca da University of Michigan, Estados Unidos, durante o estágio de doutorado em 2006-2007 e financiado pelo Programa de Doutorado com Estágio no Exterior da Coordenação de Aperfeiçoamento de Pessoal (PDEE/Capes), Ministério da Educação. A revisão final do texto foi realizada no Centro de Estudos da Metrópole/ Centro Brasileiro de Análise e Planejamento (CEM/Cebrap) em São Paulo, com apoio financeiro da Fundação de Amparo à Pesquisa do Estado de São Paulo (Fapesp). Os autores gostariam de agradecer a Jairo da Matta, mestre em Políticas Públicas e Saúde da Fundação Oswaldo Cruz (Fiocruz), pelos comentários ao texto.
} 
No século XVI, o uso medicinal do ópio estava solidamente estabelecido em diversos países da Europa, especialmente na Inglaterra (Berridge \& Edwards, 1981), e até o início do século XIX acreditava-se que o consumo da substância não causava qualquer malefício. O ópio era utilizado de forma regular por intelectuais, como o escritor norte-americano Edgard Allan Poe ou o escritor inglês Thomas De Quincey. No seu famoso relato autobiográfico, Confessions of an English Opium Eater, publicado pela primeira vez em 1822, De Quincey descreve os prazeres, as alucinações e as dores provocadas pelo consumo contínuo de grandes quantidades de ópio (De Quincey, 1998).

No mesmo período, outra substância com poderes anestésicos e estimulantes começava a circular na Europa - a cocaína. Tal substância (e outros alcaloides da coca) era há muito utilizada pelas populações nativas da região andina da América do Sul (no que hoje seria o território ocupado pelo Peru, Bolívia e Colômbia), sendo originalmente consumida sob a forma de folhas de coca mascadas ou infusões (chás) de folha de coca. A coca foi levada para a Europa em pequenas quantidades pelos conquistadores espanhóis, ao longo dos séculos XVII-XIX. Em 1863, o químico francês Angelo Mariani criou o Vinho Mariani, uma mistura de vinho e infusão de coca, que rapidamente se tornou popular em toda a Europa (Allen, 1987). Por essa mesma época, a companhia química e farmacêutica Merck sintetizou a cocaína em pó a partir de folhas de coca maceradas e purificadas (Byck, 1975).

As propriedades anestésicas da cocaína (nos dias de hoje empregadas amplamente sob a forma de seus derivados, como a xilocaína, anestésico utilizado em odontologia e diversas outras cirurgias de pequeno porte) foram descobertas por um médico russo, Vassili von Anrep, em 1880, quando este percebeu a perda de sensibilidade no local da injeção após a administração da droga. Anrep era professor de Sigmund Freud, porém, à época, o interesse principal do Pai da psicanálise não se dirigia às propriedades anestésicas locais da cocaína, mas sim ao seu potencial estimulante. Um contemporâneo e colega de Freud, Karl Koller, acabou por introduzir a cocaína na cirurgia oftálmica (Byck, 1975).

Freud fez uso da cocaína em diversos momentos e, entre 1884-1885, publicou uma série de artigos sobre o tema, relatando os efeitos benéficos da substância no tratamento da fadiga, impotência e depressão. A fama da coca atravessou o Atlântico e, em 1886, John Styth, nos Estados Unidos, desenvolveu uma bebida estimulante à base de infusão de coca e cafeína, conhecida como Coca-Cola - que, desde 1901, contém diferentes alcaloides, mas não mais a cocaína (Allen, 1987). 
Como demonstram os exemplos históricos mencionados, até meados do século XIX, a produção, a comercialização e o consumo de substâncias hoje classificadas como drogas, como a cocaína e o ópio e seus derivados, eram amplamente difundidos.

Como uma substância tão largamente consumida, como o ópio, com benefícios amplamente reconhecidos pela medicina (tanto que, até hoje, os opiáceos continuam a ser os principais analgésicos utilizados na prática médica e cirúrgica no manejo de dores de grande intensidade), tornou-se um problema?

Berridge e Edwards (1981) afirmam que a questão de modo algum se limita às propriedades da(s) substância(s) em si (afinal, suas propriedades farmacológicas se mantêm idênticas ao longo dos séculos), mas sim ao contexto social e econômico e aos usos específicos (frequentemente, com finalidades contrastantes) das diferentes substâncias, hoje consideradas lícitas ou ilícitas. As mortes associadas ao uso inadequado e à adulteração dos derivados do ópio constituem uma das razões que fizeram com que os médicos ingleses, pela primeira vez, questionassem o livre consumo dessas substâncias. Mas não resta dúvida de que as razões de Estado prevalecem na proibição subsequente do ópio e seus derivados, e de outras substâncias psicoativas, como veremos a seguir.

\section{A Regulação Internacional sobre Drogas}

\section{A gênese dos tratados internacionais}

O primeiro grande conflito relacionado ao comércio de drogas ficou conhecido como a 'guerra do ópio'. À época, a Inglaterra mantinha um intenso contato com a China, comercializando o ópio trazido basicamente da Índia. O ópio, em 1839, representava metade das exportações inglesas para a China. O governo chinês, em resposta à elevada importação e consumo de ópio, publicou um decreto proibindo a importação do produto e mandou queimar 20 mil caixas apreendidas de comerciantes ingleses que operavam ilegalmente. Essas ações resultaram em duas guerras entre esses países, em 1834-1843 e 1856-1858.

A China, derrotada em ambos conflitos, foi obrigada a fazer profundas concessões. Em 1842, foi assinado o Tratado de Nanquin, que obrigou o país asiático a abrir seus portos para a entrada do ópio (e outras mercadorias) trazido da Índia e da Turquia e a entregar a Ilha de Hong Kong, que permaneceu sob domínio inglês 
até 1997 (Berridge \& Edwards, 1981). Os desdobramentos desses conflitos deram lugar a uma tentativa de regulação da produção, comercialização e consumo do ópio, e se constituíram em um marco dos futuros tratados internacionais de regulação das substâncias hoje denominadas drogas.

Como mostra o pesquisador alemão Sebastian Scheerer (1993), o então denominado 'problema do ópio', gradualmente, sob forte pressão dos países hegemônicos na Liga das Nações, transformou-se no 'problema das drogas', com a sucessiva proibição da produção, comercialização e consumo de mais e mais substâncias, sucessivamente incluídas nos acordos internacionais.

De acordo com Scheerer (1993), até setembro de 1910 não havia acordo entre as duas potências então hegemônicas - Inglaterra e Estados Unidos da América (EUA) - sobre como regular a comercialização do ópio, coexistindo dois tratados de natureza distinta, ambos de abrangência regional: a Comissão Filipina do Ópio, de 1903, sob a égide norte-americana, e a Comissão de Changai, de 1909, que ratificava as decisões decorrentes da vitória inglesa na Guerra do Ópio. Uma das particularidades do conflito entre as duas potências era decorrente do esforço norte-americano para quebrar o monopólio neocolonial inglês do ópio e de outros produtos do Commonwealth (com destaque, no caso do ópio, para a Índia).

Ainda segundo Scheerer (1993), o propósito primeiro, portanto, da convocação de uma Conferência Internacional sobre o Ópio, por parte dos EUA, formulada em 1909, era aparar as arestas entre as duas potências hegemônicas, basicamente tornando internacionais as convenções, até então regionais, sobre o ópio. À Inglaterra interessava um controle brando sobre o ópio (sobre o qual detinha um controle monopolista) e um controle rígido sobre a morfina (derivado do ópio) e, particularmente, sobre a cocaína que, como vimos, era fabricada por indústrias farmacêuticas, como a Merck e outras companhias de capital alemão, país que era o grande rival da Inglaterra no continente europeu. A contraproposta inglesa à convocação norte-americana, formulada em setembro de 1909, foi finalizada um ano depois e enviada, em setembro de 1910, à diplomacia norte-americana.

Ao deslocar o foco da conferência do comércio monopolista do ópio (embora, ao longo do processo, tenha cedido quanto a esse ponto) para a produção farmacêutica de morfina e cocaína, a Inglaterra aplicou um golpe de mestre no contexto da diplomacia internacional, passando de vilã neocolonialista à guardiã da temperança, ameaçada pela produção desenfreada de morfina e cocaína e pelo consumo abusivo de ambas as substâncias. A guerra 
contra a cocaína movida pela Inglaterra vinha ainda ao encontro dos esforços norte-americanos de controlar o seu uso, que até então se materializava com a proibição da comercialização e uso da cocaína no âmbito de várias legislações estaduais norte-americanas.

A Conferência Internacional ocorrida em 1912 na cidade de Haia, na Holanda, contou com 12 países. O entrechoque das formulações da Inglaterra daí em diante com o apoio enfático dos EUA - em contraposição à posição do Império alemão - com o apoio de países sob sua órbita de influência e países com uma postura mais liberal, como a França - fez com que as deliberações da Conferência de Haia não fossem ratificadas pelos países-membros da Liga das Nações se não a partir da convocação de sucessivas reuniões subsequentes, num período que se estendeu por nove anos. A ratificação completa e definitiva da Convenção de Haia, que incluía a proibição da produção, comercialização e consumo de diferentes substâncias, como a cocaína e a morfina (excluindo o uso médico, quanto a esta última), só ocorreu de fato em 1919, já no contexto do Tratado de Versailles, após a derrota da Alemanha e seus aliados na I Guerra Mundial (Scheerer, 1993). Nascia a partir daí o atual sistema de controle de diferentes drogas, sob a hegemonia inconteste da Inglaterra e dos EUA, e, em um momento posterior, sob a hegemonia absoluta e praticamente exclusiva dos EUA.

\section{Os tratados internacionais}

Os protocolos conhecidos como as convenções de drogas da Organização das Nações Unidas (ONU) - a Convenção Única de Narcóticos, de 1961, a Convenção de Drogas Psicotrópicas, de 1971, e a Convenção contra o Tráfico Ilegal de Narcóticos e Substâncias Psicotrópicas, de 1988 - guiam e atrelam a política de drogas mundial à força das convenções internacionais, e, em boa medida, subordinam as políticas nacionais referentes às drogas daí em diante ditas ilícitas. Essas convenções se revestem de grande força e autoridade, uma vez que foram ratificadas por 160 nações. Os acordos impõem limites sociais, culturais e mesmo morais ao comércio e consumo das substâncias psicoativas, definindo as linhas que distinguem o que é lícito e ilícito.

CONVENÇão ÚNICA DE NARCóticos (1961) - esta convenção definiu duas formas de controle das drogas. A primeira delas tem por objetivo limitar a posse, o uso, o comércio, a distribuição, a importação, a manufatura e a produção de drogas exclusivamente para uso médico e científico. A segunda normatiza o 
combate ao tráfico de drogas por meio da cooperação internacional, visando a desencorajar e, se possível, impedi-lo. Esta convenção definiu as substâncias a serem controladas, tomando por base o grau de perigo ou abuso, potencial dependência e uso médico das diferentes substâncias (o que é objeto de críticas importantes de profissionais da área que, frequentemente, discordam dos critérios adotados e das evidências em que estes se baseariam). As substâncias incluídas no Grupo, entre elas, a heroína, a cocaína e a maconha, estão sujeitas a todas as medidas de controle previstas na convenção. O Grupo II compreende substâncias habitualmente utilizadas com finalidade médica e que requereriam um controle menor, pois apresentariam um potencial de abuso menor. A codeína (analgésico, antitussígeno e opiáceo), isto é, produto empregado em xaropes contra a tosse, por exemplo, está incluída neste segundo grupo. O Grupo III contempla as exceções, como, por exemplo, uma série de substâncias farmacêuticas preparadas com resíduos químicos passíveis de abuso, e, portanto, com baixo potencial danoso. O Grupo IV inclui as substâncias essenciais à prática médica e à investigação cientifica. Além disso, nessa convenção foi instituído o International Narcotics Control Board (INCB), órgão que tem por responsabilidade supervisionar a implementação das convenções de controle das drogas.

Convenção de Drogas Psicotrópicas (1977) - estabeleceu o sistema de controle internacional para outras substâncias psicotrópicas, como os barbitúricos, o ácido lisérgico (LSD) e as anfetaminas. Esta convenção teve por objetivo discutir a diversificação e a expansão do abuso de drogas no mundo e introduzir o controle sobre as drogas sintéticas, de acordo com o seu potencial de abuso e valor terapêutico.

Convenção contra o Tráfico Ilegal de Narcóticos e Substâncias PsicotróPICAS (1988) - o crescente problema do tráfico de drogas ao longo dos anos 70 e 80 motivou a convocação de uma nova reunião das Nações Unidas visando a estabelecer medidas abrangentes para lidar com essa questão. Esta convenção estabeleceu novas medidas contra o comércio de drogas, lavagem de dinheiro, produção e comercialização de precursores químicos utilizados na fabricação de diferentes substâncias psicoativas. Todos os países signatários dessa convenção devem definir como crime a posse ou o cultivo de narcóticos ou drogas psicotrópicas para consumo pessoal. O ato de estimular outra pessoa a consumir drogas também é definido como crime.

O propósito das duas primeiras convenções foi estabelecer uma regulamentação internacional sobre quais substâncias poderiam ser utilizadas com finalidade médica e científica e quais deveriam restringidas em função do 
seu potencial de abuso e dependência. Ficou a cargo da Organização Mundial da Saúde (OMS), a agência das Nações Unidas com poder normativo na área da saúde, avaliar cada uma das substâncias psicoativas e orientar a Comissão de Drogas Narcóticas (CDN) sobre a classificação das diferentes substâncias nos diferentes grupos compreendidos nas Convenções de 1961 e 1971 (Bewley-Taylor, 2003).

Essas convenções foram uma resposta a questões sociais e políticas relacionadas ao uso de drogas em momentos determinados da história. A necessidade de estabelecer um código comum que harmonizasse a resposta das diferentes nações ao problema do consumo de drogas, de marcar os limites para o seu uso medicinal e científico e de criar medidas de controle do tráfico de drogas integra os esforços de sedimentação de uma ordem global. Porém, basicamente ao longo dos anos 80 , as políticas supranacionais antidrogas entraram em crise. Levine (2003) aponta três fatores críticos que contribuíram para isso: a emergência e a expansão do movimento de 'redução de danos', ${ }^{2}$ em resposta, especialmente, à crescente epidemia de Aids entre usuários de drogas injetáveis; a crescente oposição às políticas de drogas de cunho essencialmente coercitivo e punitivo, que criminalizam o usuário de drogas; a incapacidade das políticas proibicionistas para limitar o cultivo e o consumo da maconha, droga que ganha grande aceitação social nos anos 60 e 70.

\section{Convenções internacionais e saúde pública: diálogo e contradição}

Como foi visto anteriormente, as duas primeiras convenções precederam a emergência da epidemia de Aids, tendo sido a terceira convenção aprovada antes que se consolidasse o conhecimento de que o uso de drogas injetáveis poderia representar um problema relevante na dinâmica global da epidemia (Wolfe \& Malinowska-Sempruch, 2004).

Em países como a China e em toda a região do Leste Europeu a epidemia de HIV/Aids foi fortemente influenciada pela disseminação do HIV entre usuários de drogas injetáveis. Em 2005, o uso de equipamentos de injeção contaminados nos países do Leste Europeu esteve associado a quase dois terços (63\%) dos novos casos da doença quando a informação sobre o modo de transmissão

\footnotetext{
2 O movimento de redução de danos emerge nos anos 80 como uma resposta pragmática à epidemia de Aids entre usuários de drogas injetáveis, embora tenha raízes bem mais antigas, que datam do Relatório Rolleston, publicado na década de 1930, na Inglaterra.
} 
já estava disponível (EuroHIV, 2005). Os dados de 2005 apontam que a epidemia de Aids entre usuários de drogas injetáveis na China atingiu proporções alarmantes. Quase a metade (44\%) das pessoas vivendo com HIV na China foram infectadas em função do uso de seringas e agulhas contaminadas (Unaids, 2006; WHO, 2006). Além disso, cerca de um milhão e meio de pessoas infectadas vivem hoje nos Estados Unidos, e 13\% delas são usuários de drogas injetáveis (Unaids, 2006; CDC, 2006).

Em contrapartida, pensava-se até pouco tempo atrás que o uso de drogas injetáveis não desempenhava um papel relevante na epidemia em curso na África subsaariana, mas trabalhos recentes mostram que esta visão é incorreta (Beckerleg, Telfer \& Sadiq, 2006; McCurdy et al., 2006).

Em resposta à disseminação da epidemia de Aids entre usuários de drogas injetáveis, diversas estratégias de saúde pública foram desenvolvidas. Defensores dessas ações enfatizam o papel central da adoção, em momento o mais precoce possível, de medidas de saúde pública com adequada cobertura, como programas de troca de seringas e, mais recentemente, a expansão de salas para usuários de drogas injetáveis (Kerr et al., 2005). Além disso, ativistas defendem uma política de drogas mais tolerante e menos coercitiva.

As epidemias que envolvem patógenos de transmissão sanguínea e/ou sexual e que têm no compartilhamento de seringas e outros equipamentos de injeção um componente essencial caracterizam-se por uma disseminação particularmente rápida e extensa (Rhodes et al., 2002).

A estigmatização e a marginalização dos usuários de drogas injetáveis fazem com que eles se isolem e evitem o contato com serviços sociais e de saúde; isso, somado ao permanente risco de detenção, estimula a autoadministração de drogas em locais ermos e sem nenhuma higiene, o que favorece a não desinfecção dos equipamentos de injeção/uso exclusivo de material estéril e o compartilhamento inseguro de seringas potencialmente contaminadas.

As imposições legais impedem o desenvolvimento de medidas de saúde pública em diferentes locais - como a não implementação de programas de manutenção com metadona na Rússia ou a proibição, revogada apenas na administração Obama, do uso de recursos federais no financiamento de programas de troca de seringas nos EUA -, essenciais ao adequado manejo de usuários de drogas com quadros graves de dependência e sob particular risco de se infectar por diferentes patógenos e de overdose. A terapia de manutenção por metadona é até hoje proibida em países como a Rússia - tendo em vista que essa se encontra entre as substâncias incluídas no Grupo I da Convenção de 1961 -, a despeito 
de amplas evidências científicas em prol do uso da substância na prevenção da disseminação do HIV/Aids (Kerr et al., 2004).

Feito este retrospecto histórico, discutiremos as principais características das forças que atuam no sentido de constranger a adoção de políticas públicas mais flexíveis e pragmáticas no que diz respeito ao problema das drogas, a partir de duas perspectivas:

A. Existe na literatura um consenso de que os Tratados Internacionais Antidrogas limitam a ação individual dos países. Pretendemos discutir alguns fatores envolvidos na formulação de políticas (policy-making) da Comissão de Narcóticos das Nações Unidas.

B. Políticas, quaisquer que sejam elas, não são implementadas num vácuo, mas sim no contexto político-institucional de cada país. Cabe discutir em que medida os marcos institucionais de uma dada nação podem constranger ou facilitar a adoção das estratégias de redução de danos. Discutiremos brevemente como algumas características da formulação de políticas em nível internacional têm influenciado a política de drogas no atual cenário brasileiro e vice-versa.

\section{Considerações sobre a Formulação de Políticas no Contexto da UNODC e a Participação do Brasil}

As convenções antidrogas têm por objetivo regular o uso de diferentes substâncias químicas para uso medicinal e, ao mesmo tempo, estabelecer normas visando a prevenir e a controlar o abuso em relação ao uso de algumas dessas substâncias. Quase todos os países signatários adotaram leis restritivas ao consumo de drogas, alinhando suas políticas nacionais às normas internacionais. Para melhor compreender como se opera, na prática, o processo político envolvido na formulação e na aplicação da legislação supranacional, discutiremos três pontos relevantes: a estrutura de veto adotada pelas Nações Unidas, a burocracia institucional do Escritório de Combate ao Crime e Drogas (UNODC) e a alocação de recursos em rubricas predefinidas por parte dos países-membros (através do financiamento de ações específicas). 


\section{As decisões políticas}

As decisões no âmbito da Comissão de Narcóticos são tomadas por meio de consenso, assim como ocorre na Assembleia Geral da ONU. Na forma como é acordado pelas Nações Unidas, o consenso tem por objetivo estimular o processo de negociação e o debate em torno de um determinado tema, sem a necessidade de recorrer à votação. Se algum membro da comissão se opuser a uma resolução em particular, esta deverá ser negociada pelo tempo necessário até que se chegue a um denominador comum. Não raro, é possível encontrar relatos de chefes de delegações que afirmam cooperar com o consenso, mas que prefeririam abster-se, caso as decisões pudessem ser votadas. Afirmativas como essa sublinham os pontos fracos desse tipo de negociação e eventual acordo (Osmanczyk, 1990).

Uma vez que as decisões sejam efetivamente tomadas, só poderão ser alteradas com base em um novo consenso. Isto se aplica literalmente às convenções antidrogas. Caso se deseje alterar as normas regulatórias propostas pelos três tratados, hoje vigentes, todos os países signatários deverão estar de acordo.

A maioria dos países-membros das Nações Unidas têm, ao longo dos anos, se colocado como contrários a mudanças na legislação supranacional antidrogas. Países com orientação majoritariamente conservadora, como os Estados Unidos, a Suécia e o Japão apoiam a manutenção (quando não a escalada proibicionista) do status quo, ao passo que o Reino Unido (não de forma sistemática, sob a administração Tony Blair e Gordon Brown) e a Holanda têm habitualmente se situado em polo oposto.

O Brasil tem tido uma participação importante nas reuniões das Nações Unidas e em outros fóruns internacionais correlatos. Por ocasião da $49^{\circ}$ Sessão da Comissão de Narcóticos, em 2006, representantes do governo brasileiro apresentaram um documento, a partir de uma proposta sugerida pelo Programa Nacional de DST/Aids (PN DST/Aids) e pela Coordenação de Saúde Mental do Ministério da Saúde, relatando a experiência com as ações de redução de danos no país (PN DST/Aids, 2006). No ano seguinte, por ocasião da $50^{\circ}$ Sessão, o representante do governo do Reino Unido e presidente da Associação Internacional de Redução de Danos (IRHA), Gerry Stimson (2007), apresentou um documento à comissão, com evidências que comprovavam a disseminação da Aids entre usuários de drogas injetáveis em diversos países em desenvolvimento. Foi também mencionado o apoio técnico e financeiro que o Reino Unido 
tem fornecido à China, Rússia, Quênia, países da Ásia Central e ao Vietnã, visando ao controle da epidemia (Declaração de Viena, 2006).

Para complicar ainda mais o debate, algumas delegações que representam os países são compostas exclusivamente por profissionais não especializados, geralmente representantes dos ministérios das relações exteriores de cada país e diplomatas com pouco ou conhecimento específico sobre o tema. Esse é mais um dos fatores que perpetuam a inércia da comissão (Fazey, 2003).

As reuniões que formularam os três tratados antidrogas hoje vigentes representaram 'janelas de oportunidade', através das quais teria sido possível mudar o rumo das políticas de drogas no mundo, caso houvesse vontade política para tal. As motivações políticas (politics) subjacentes às decisões adotadas pelos representantes dos países-membros no contexto das sessões de discussão da Comissão de Narcóticos - referentes à regulação do consumo e do comércio -, assim como aos marcos que norteiam a prevenção, resultaram na atual política (policy) de drogas. Uma vez traçados os rumos dessa política, os custos e as dificuldades envolvidos no sentido de alterá-las mostram-se particularmente elevados, fazendo-se necessário aguardar um momento estratégico para que o problema volte à pauta dos debates na arena política decisória (Kingdom, 1995).

\section{A administração das decisões da Comissão de Narcóticos}

As decisões políticas da Comissão de Narcóticos são formalmente supervisionadas pelo staff de profissionais que trabalham no Escritório de Combate ao Crime e Drogas (United Nations Office on Drugs and Crime - UNODC), em Viena, Áustria. A UNODC tem por objetivo apoiar e assistir os países-membros na implementação e ratificação dos acordos firmados no âmbito da Comissão de Narcóticos e na formulação e aplicação da legislação doméstica em drogas, crime e terrorismo (UNODC, 2007a). A literatura internacional mostra que a formulação e a implementação das políticas são bastante dependentes das ações da burocracia institucional (Page, 1985; Allison \& Zelikow, 1999). Segundo pesquisadores, o staff que administra as decisões políticas não tem uma postura neutra e desempenha um papel importante, principalmente na orientação dos gastos públicos relativos às políticas de drogas.

O quadro organizacional e institucional descrito por Fazey (2003) mostra que os especialistas da UNODC sofrem um forte constrangimento quando se fala em reformular a organização institucional e em propor políticas inovadoras. A falta de estabilidade do vínculo empregatício e a diversidade cultural desses 
profissionais (incluindo a falta de fluência nos idiomas oficiais da instituição) impedem um funcionamento mais eficiente da organização. Além disso, o fato de mais de $80 \%$ dos recursos do fundo da UNODC serem destinados a projetos com finalidades específicas impede que o seu diretor executivo proponha projetos alternativos àqueles formulados pelos países doadores desses recursos.

As políticas efetivamente adotadas são determinadas não apenas pela Comissão de Narcóticos, mas também pelos países-membros, de forma individual, à medida que são direcionados recursos para projetos específicos. A título de exemplo, observa-se que, ao longo de muitos anos, os recursos destinados pelos Estados Unidos à organização não podiam ser utilizados para financiar, por exemplo, programas de troca de seringas.

Uma forma encontrada para contornar imposições dessa natureza foi financiar os projetos de redução de danos por meio de 'pacotes' de ações voltadas para a prevenção e educação em Aids. O projeto brasileiro de controle da Aids, financiado parcialmente pelo Banco Mundial e pela UNODC, lançou mão dessa estratégia na implementação de suas ações de redução de danos (Fazey, 2003). O papel desses recursos se mostrou fundamental no financiamento dos programas de troca de seringas brasileiros (Fonseca et al., 2006).

Além disso, o escritório da UNODC no Brasil vem desenvolvendo projetos que contemplam ações abrangentes de prevenção à Aids e ao uso de drogas. Essa meta representa o maior investimento do escritório, no Brasil, no período 2006-2009 (Quadro 1). Esses dados evidenciam um forte incentivo às ações de redução de danos e prevenção à Aids entre usuários de drogas, em contraposição a ações de cunho repressivo vigentes em contextos políticos anteriores.

Quadro 1- Dados de financiamento UNODC/Brasil - 2006-2009*

\begin{tabular}{|l|r|}
\hline Objetivo & TOTAL \\
\hline Promover a prevenção ao uso de drogas e HIV/Aids & 18.300 .700 \\
\hline $\begin{array}{l}\text { Contribuir com os esforços nacionais para controlar o crime organizado } \\
\text { e o tráfico de drogas }\end{array}$ & 14.324 .200 \\
\hline $\begin{array}{l}\text { Contribuir com a prevenção à violência e ao crime urbano no nível } \\
\text { comunitário }\end{array}$ & 1.800 .000 \\
\hline $\begin{array}{l}\text { Cooperar com o governo brasileiro na redução de práticas de corrupção } \\
\text { e seu impacto no desenvolvimento do país }\end{array}$ & 3.305 .400 \\
\hline TOTAL & 37.730 .300 \\
\hline
\end{tabular}

Fonte: UNODC, 2006a.

* Dados referentes ao total de despesas (fundos assegurados e a serem levantados). 


\section{0 financiamento dos projetos}

Aproximadamente 90\% do orçamento da UNODC é oriundo da doação voluntária de recursos por parte dos países-membros, ao passo que apenas 10\% se refere ao orçamento regular, repassado pelas Nações Unidas. Os recursos provenientes dos países-membros podem ser compostos por doações com finalidade específica (earmarked) - direcionadas a determinados projetos - e por recursos com propósito mais amplo - investidos de acordo com as orientações do diretor executivo do órgão (Fazey, 2003; UNODC, 2007a).

Os dados que constam do Gráfico 1 indicam uma tendência crescente, com mais de $50 \%$ do orçamento global da instituição destinada de antemão a finalidades específicas. No ano de 2006 , mais de $80 \%$ do orçamento do órgão foi direcionado para projetos escolhidos pelos doadores. Isso evidencia o limite operacional imposto aos gestores da UNODC, no sentido de tentar flexibilizar suas inversões financeiras e projetos.

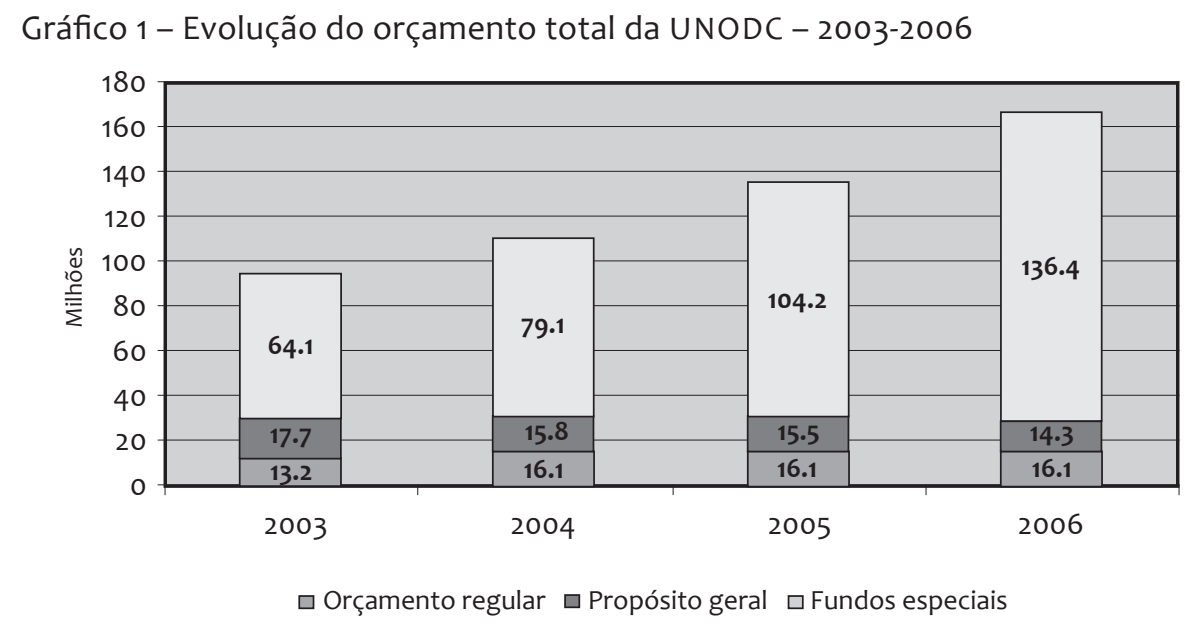

Fonte: adaptado do UNODC, 2006b.

Atualmente, figura entre os doadores principais da UNODC a União Europeia, e, entre os países individuais, a Suécia, os Estados Unidos e o Reino Unido, respectivamente (Tabela 1). O grupo dos 'principais doadores' é constituído por 21 países, ao passo que o grupo dos 'doadores emergentes' é constituído por 38 países, correspondendo a, respectivamente, $62 \%$ e $32 \%$ do orçamento global do órgão. Um achado especialmente relevante refere-se ao fato de o Brasil ter 
doado, em 2006, US\$ 36 milhões ao fundo para projetos específicos de combate às drogas. Esse valor ultrapassa as contribuições mais importantes dos principais doadores tradicionais.

Tabela 1 - Ranking das doações ao fundo contra drogas e crime da UNODC por grupo de países, 2006

\begin{tabular}{|c|c|c|c|c|c|}
\hline & Doador & $\begin{array}{c}\text { Fundos } \\
\text { específicos }\end{array}$ & $\begin{array}{c}\text { Propósito } \\
\text { geral }\end{array}$ & TOTAL & $\%$ \\
\hline \multirow{5}{*}{$\begin{array}{l}\text { Principais } \\
\text { doadores }\end{array}$} & 1. União Europeia & 15.843 .519 & & 15.843 .519 & 17.1 \\
\hline & 2. Suécia & 10.959 .126 & 2.268 .306 & 13.227 .432 & $14 \cdot 3$ \\
\hline & 3. USA & 11.145 .536 & 1.000 .000 & $12.145 \cdot 536$ & 13.1 \\
\hline & 4. Reino Unido & 10.856 .569 & & 10.856 .569 & 11.7 \\
\hline & TOTAL DO GRUPO & 80.439 .006 & 13.290 .888 & 93.729 .894 & \\
\hline \multirow{4}{*}{$\begin{array}{l}\text { Doadores } \\
\text { emergentes }\end{array}$} & 1. Brasil & 36.767 .671 & & 36.767 .671 & 75.7 \\
\hline & 2. Colômbia & 6.198 .810 & & 6.198 .810 & 12.8 \\
\hline & 3. Mexico & 1.487 .333 & 100.000 & 1.587 .333 & $3 \cdot 3$ \\
\hline & TOTAL DO GRUPO & 47.292 .843 & 1.026 .615 & 48.319 .458 & \\
\hline
\end{tabular}

Fonte: adaptado do UNODC, 2007.

Em última instância, os tratados internacionais ditam as regras do jogo quanto à regulação das drogas medicinais e narcóticos. Como mostrado anteriormente, mudar o status quo exige obter um consenso entre todos os países-membros, tarefa extremamente complexa e de execução particularmente morosa. Porém, algumas alternativas poderiam vir a ser adotadas pelos países que pretendem adotar políticas de drogas mais flexíveis.

Uma alternativa radical seria dissociar ('romper') as políticas nacionais dos tratados internacionais, o que deixaria os formuladores nacionais de políticas de drogas inteiramente livres para direcionar a política local no sentido que lhes parecer mais apropriado. Essa alternativa é claramente radical e pode dar lugar a consequências imprevisíveis para a ordem política global. Os acordos multilaterais são importantes no sentido de estabelecer um consenso sobre determinados assuntos. Uma vez quebrada a aliança, isso pode ter consequências para a credibilidade do país em outras áreas. Além disso, o mais das vezes, os políticos e técnicos locais não têm um interesse firme no sentido de defender e arcar com os custos políticos e econômicos potencialmente associados a um tema tão polêmico como o consumo e o comércio de drogas. 
Os tratados antidrogas não são autoaplicáveis. Isso significa que as convenções impõem restrições à formulação das leis nacionais, porém os países contam com alguma margem de manobra quanto à formulação de suas políticas domésticas. Alguns países argumentam, nesse sentido, que controlar a epidemia de Aids entre usuários de drogas é uma questão mais premente do que o combate ao consumo abusivo de drogas per si. Alinham-se nessa posição países como o Reino Unido, o Canadá e a Holanda. A política de drogas holandesa distingue claramente a comercialização e o consumo da maconha do comércio e consumo das drogas ditas 'pesadas' (como a cocaína e a heroína), e permite o uso da maconha em cafés, nos quais o usuário não necessariamente adquire a droga (algumas coffee shops também comercializam a maconha), mas pode usá-la sem restrições. Outros exemplos são o da Austrália e do Canadá, que disponibilizam salas de uso mais seguro para usuários de drogas injetáveis, e, ainda uma vez, o Canadá, que autorizou o uso medicinal da maconha. Na Suíça e Espanha é permitido aos médicos prescrever heroína a pacientes que apresentem quadros graves de dependência dessa substância e não respondam adequadamente à terapia de manutenção com a metadona (March et al., 2006).

Todas essas iniciativas foram criticadas pelo INCB. Porém, ao contrário do que habitualmente se pensa, esta agência não tem o poder de arbitrar interpretações conflitantes das convenções (Bewley-Taylor, 2003). Além dos constrangimentos internacionais, uma variável importante e que deve ser levada em consideração é o contexto político-institucional em que essas políticas são implementadas. Essas variáveis permitem aos países adotar políticas diferenciadas, mesmo sob um regulamento internacional único.

\section{Políticas, Desafios e Perspectivas de Mudança no Brasil}

Os tratados internacionais de drogas não são implementados em um vazio institucional. Como visto, os países apresentam diferentes alternativas para lidar com a regulação das drogas, variando de um extremo proibicionista, como o modelo norte-americano, a um extremo liberal, como o holandês e o britânico (Fonseca \& Bastos, 2005). O processo por meio do qual uma política é discutida, aprovada e implementada tem impacto sobre a natureza das políticas públicas adotadas. Esse processo molda e tem profundo impacto na falha ou no sucesso de qualquer política. A formulação de políticas é complexa e resulta da interação 
de múltiplos atores, com diferentes poderes, objetivos e interesses. Existe ainda uma variedade de arenas onde as decisões são tomadas e com diferentes regras que determinam o modo "como o jogo é jogado" (Stein et al., 2005: 7). Discutiremos a seguir alguns impasses e os avanços enfrentados no contexto da reformulação da política de drogas no Brasil.

\section{0 sistema político}

Recentemente, o governo brasileiro empreendeu duas reformulações na sua política nacional antidrogas, em substituição à antiga lei n. 6.368, de 1976 (Brasil, 1976), que criminalizava o uso de drogas. Segundo a legislação aprovada em 2002 (lei n. 10.409), o usuário de drogas era punido com até dez distintas modalidades de penas alternativas ou dois anos de prisão (Brasil, 2002). Essa primeira alteração na legislação abriu um precedente para que uma nova proposta, sancionada pelo presidente Luis Inácio Lula da Silva quatro anos mais tarde, emergisse (lei n. 11.343/06). A nova legislação estabelece uma distinção clara entre a posse e uso de pequenas quantidades de drogas e o tráfico de drogas (Brasil, 2006). Sob essa perspectiva, o usuário de drogas será punido com penas alternativas e não mais com o encarceramento. Essa alteração pode ser considerada um avanço relevante, pois descriminaliza o uso de drogas e permite uma intervenção menos ativa do direito penal sob a conduta individual, diminuindo o contingente da população carcerária (Bastos et al., 2007).

Mudar uma legislação, seja no Brasil ou em qualquer outro país, especialmente em um país grande e heterogêneo, não constitui tarefa fácil. O funcionamento de um Estado federalista é complexo e não necessariamente harmônico. Existem diversos atores em cena, com diferentes interesses e diferentes capacidades de impor veto às propostas de mudança mais controversas. Mudanças na legislação brasileira exigem a obtenção da maioria nas duas casas legislativas e a sanção do presidente da República. A fragmentação do sistema partidário no Brasil representa um dos maiores obstáculos à formação de coalizões consistentes e sólidas que tenham como objetivo implementar quaisquer mudanças. Somado a isso, o presidente, no Brasil, tem um papel preeminente na definição da agenda política e na formulação de propostas (poderes proativos: pode legislar através de decretos-lei, tem poder sobre o orçamento e pode designar os ministros; e poderes reativos: pode vetar parcialmente os projetos de lei (Costa, 2004; Stein et al., 2005). 
Assim, para aprovar uma legislação ousada como a que propõe reformulações da política de drogas, um conjunto de atores deve estar de acordo com essas mudanças. O primeiro discurso do presidente Lula sobre o crime organizado e a segurança pública foi recebido com otimismo pelos ativistas em prol de uma política de drogas menos repressiva. Além disso, o ministro da Justiça, alguns dias antes do discurso do presidente, havia declarado a um comitê no Congresso ser favorável à descriminalização do uso de drogas (Narconews, 2003). Este, assim como outros fatores discutidos mais adiante, favoreceram a aprovação da nova legislação.

Um projeto de lei federal n. 1.279/99 (Brasil, 1999), que dispõe sobre o fornecimento de seringas e agulhas descartáveis e esterilizadas em centros e entidades de tratamento e recuperação de usuários de drogas, foi arquivado pela mesa diretora da Câmara dos Deputados em 2007 (no momento em que redigimos este capítulo, julho de 2011). Este projeto aguarda uma janela de oportunidade para que seja reaberto e votado em plenário.

Alguns estados e municípios brasileiros já contam com leis que regulamentam as ações de redução de danos em suas respectivas jurisdições. Em princípio, os estados e municípios são autônomos quanto a conduzir as suas políticas de saúde, educação, meio ambiente, transporte etc. - ainda que, habitualmente, precisem do apoio e concordância do governo federal para desenvolver políticas consistentes, a exemplo do funcionamento do Sistema Único de Saúde (Costa, 2004). Fato é que, valendo-se da competência para legislar sobre as ações de proteção e defesa da saúde (artigo 24 da Constituição Federal), estados como São Paulo, Santa Catarina, Rio Grande do Sul, Mato Grosso do Sul, Espírito Santo, Minas Gerais, e municípios como Vitória, São Paulo, entre outros, aprovaram em suas respectivas legislações as atividades de redução de danos como uma forma de controlar a epidemia de Aids. Essas leis têm o papel fundamental de integrar as ações de redução de danos às políticas públicas de saúde e de garantir aos profissionais que trabalham 'na ponta' (na cena de uso) respaldo legal para desenvolverem essas ações, sem a interferência da polícia (Karam, 2003).

\section{Burocracia institucional}

O esforço para mudar a política de drogas no Brasil conta ainda com dois atores-chave: a burocracia institucional e o movimento social. Estes podem ser considerados os motores que impulsionaram o processo de reformulação da política de drogas no Brasil. A burocracia institucional desempenha um papel impor- 
tante no sistema democrático e na aplicação das decisões políticas (Page, 1985; Allison \& Zelikow, 1999). Os burocratas são o que Kingdom (1995) denominou "comunidades de especialistas", que fornecem aos agentes executivos informações e estatísticas a respeito dos problemas merecedores de prioridade e maior atenção na agenda pública. Segundo o autor, a fonte de influência desses agentes se deve, particularmente, à longevidade da carreira pública (enquanto os políticos se alternam no poder, os burocratas permanecem), e à sua expertise (especialização em determinada área), além de sua relação com o Congresso e os grupos de interesse.

A burocracia no Brasil é, em grande parte, autônoma e especializada. Composta por um quadro permanente de servidores públicos recrutados pelo mérito e incorporados ao Estado com planos de carreira e incentivos que favorecem o desempenho profissional (Stein et al., 2005). Essas características da burocracia institucional brasileira em certas áreas, como saúde e ciência e tecnologia, facilitaram a sensibilização dos gestores estaduais (principalmente em São Paulo, Rio de Janeiro, Bahia e Rio Grande do Sul) e federais para a adoção de uma resposta pragmática e de saúde pública diante da então crescente epidemia de Aids entre usuários de drogas injetáveis, em meados da década de 1990. Os estudos e pesquisas, financiados, inicialmente pela OMS, constituíram a linha de base para a ampla implantação de Programas de Troca de Seringas nos anos 90 e da década seguinte.

Derivam daí algumas questões importantes. Em primeiro lugar, há que se saber que, apesar de o recrutamento e de a seleção dos funcionários da administração pública serem feitos com base em critérios meritocráticos, existem outras formas de ingresso no serviço público, especialmente em caráter temporário. Por exemplo, a ampla composição do quadro de profissionais do PN DST/Aids é oriunda do movimento de organizações não governamentais (ONGs), de profissionais de saúde e pessoas vivendo com HIV/Aids que tinham interesse direto na implantação de programas de redução de danos no Brasil. Os funcionários do antigo Programa Nacional de Doenças Sexualmente Transmissíveis e Aids (PN Aids) ${ }^{3}$ são geralmente contratados como profissionais que atuam na assessoria técnica e exercem funções pontuais, remunerados com recursos dos acordos de empréstimo internacional. A contratação de um corpo técnico envolvido com as questões de drogas e Aids levou os grupos de interesse para o centro das instâncias decisórias e favoreceu a alocação de recursos específicos para essas ações. ${ }^{4}$ Em segundo lugar, apesar de ainda não contar

Atualmente Departamento de DST, Aids e hepatites virais.

4 Para uma discussão mais detalhada desses tópicos, ver Nunn (2007). 
com uma lei federal que regule as ações de redução de danos no Brasil, o Ministério da Saúde editou uma portaria (antecipando-se à possível aprovação dessa lei) que autoriza a distribuição de insumos de prevenção à Aids para usuários de drogas injetáveis (Brasil/MS, 2005). Essa medida não solucionou em definitivo o problema, mas contribuiu para tirar da informalidade programas que vinham funcionando há mais de dez anos, e que constantemente sofriam com a repressão policial ou eram acusados de colaborar com o uso de drogas. Em terceiro lugar, o PN DST/Aids, por meio do acordo de empréstimo com o Banco Mundial, financiou amplamente as ações dirigidas aos usuários de drogas no Brasil, criando uma coalização de interesses que mais tarde se tornaria fundamental no redirecionamento das políticas públicas de drogas. Um estudo anterior aponta que os programas de redução de danos no Brasil são fortemente dependentes desse recurso para desenvolverem suas ações (Fonseca et al., 2006). Entre 2000 e 2002 houve um crescimento constante no número de projetos financiados para a população de usuários de drogas (Gráficos 2 e 3). Em 2002, foram financiados 119 projetos, num total de R\$ 3 milhões de recursos investidos. Com a descentralização de recursos do PN DST/Aids, em 2003, esses projetos passaram e ser de responsabilidade das secretarias estaduais e municipais de saúde (Fonseca et al., 2007).

Gráfico 2 - Evolução do número de projetos para população de usuários de drogas financiados pelo PN DST/Aids* por ano de execução. Brasil, dados referentes a 498 projetos $-1999-2006$

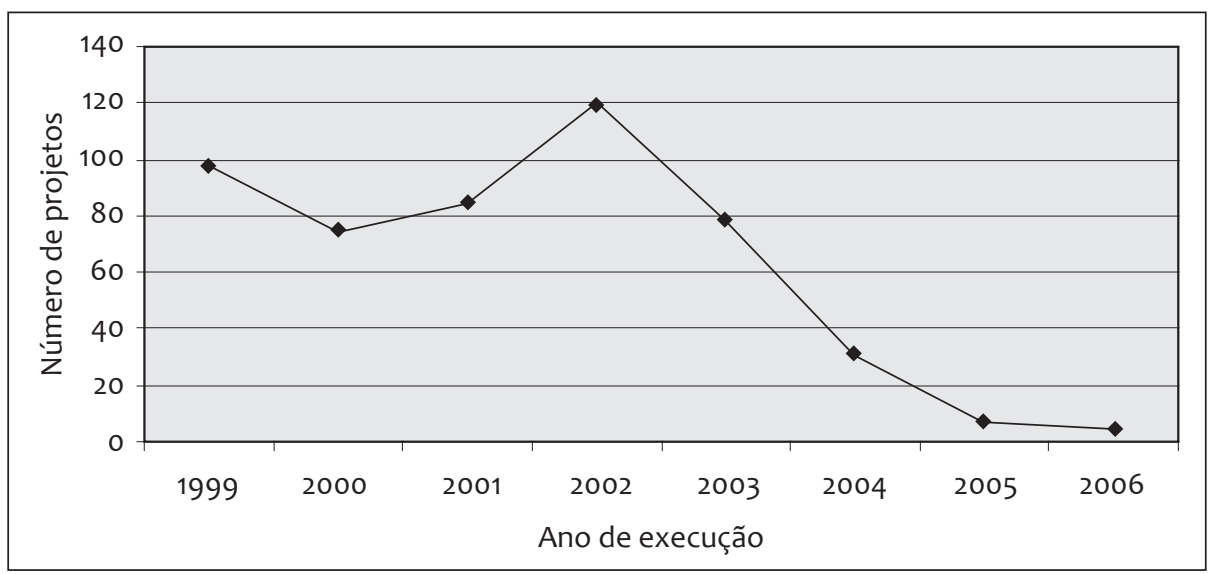

Fonte: PN DST/Aids, 2006.

*Exclui projetos financiados para órgãos governamentais. 
Gráfico 3 - Evolução dos gastos com projetos para população de usuários de drogas financiados pelo PN DST/Aids* por ano de execução. Brasil, dados referentes a 498 projetos $-1999-2006$

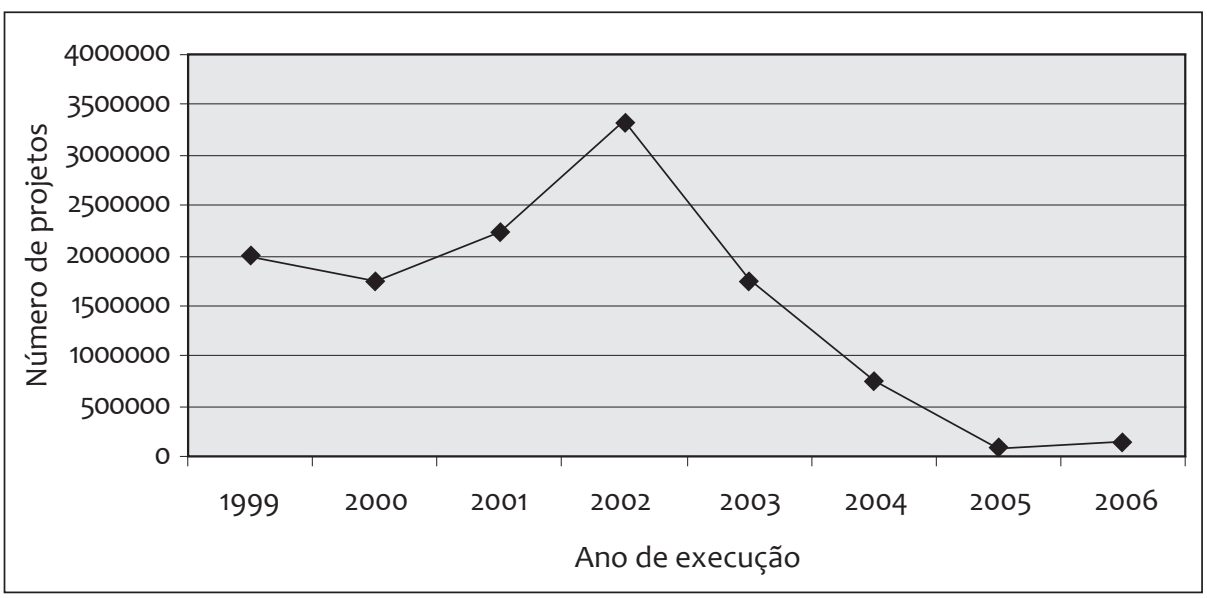

Fonte: PN DST/Aids, 2006.

*Exclui projetos financiados para órgãos governamentais.

O Brasil foi um dos primeiros países do mundo a receber ajuda externa do Banco Mundial para desenvolver ações de prevenção à Aids (World Bank, 2005). Com base em uma agenda de maximização do custo-efetividade, os economistas do Banco Mundial desenvolveram uma estratégia de alocar recursos para populações específicas, centrais à dinâmica de epidemias concentradas, como a brasileira, como os usuários de drogas injetáveis e os profissionais do sexo, particularmente vulneráveis à disseminação do HIV. Em contrapartida, os financiadores internacionais se recusavam a disponibilizar financiamento para as ações de tratamento, diagnóstico e aquisição de medicamentos para Aids (World Bank, 1999). Era mais vantajoso prevenir novas infecções do que investir no dispendioso tratamento para os doentes. A dupla fonte de recursos do PN DST/Aids permitiu aos gestores alocar os recursos da fonte Tesouro Nacional nas ações de diagnóstico e aquisição de medicamentos, ao passo que a fonte de recursos do acordo de empréstimo permitiu desenvolver ações de fortalecimento das ONGs e implementar estratégias de prevenção junto a populações específicas.

O PN DST/Aids e o Ministério da Saúde desempenharam um papel importante no financiamento do movimento de redução de danos e na capacitação de ativistas e técnicos. A partir dessas evidências, podemos afirmar que 
a coalizão de interesses em prol da redução de danos formou um núcleo em torno do PN DST/Aids e dele se nutriu. Esse apoio influenciou fortemente a agenda da política pública de drogas no Brasil, como veremos a seguir.

\section{Movimento social}

Os grupos de interesse são compostos por indivíduos que se organizam entre si para compartilhar interesses comuns e influenciar as políticas públicas e as decisões econômicas. Eles clarificam e articulam as preferências dos cidadãos, alertam os formuladores de políticas sobre a prioridade de suas propostas e sugerem formas de tornar as políticas mais aceitáveis ou aconselham a respeito de seus danos potenciais. Alguns exemplos de grupos de interesse são: as companhias farmacêuticas e suas associações de classe, as associações médicas, os sindicatos e as organizações da sociedade civil. Os grupos de interesse são importantes também para educar seus membros e a população quanto a determinadas questões e ajudá-los a implementar uma agenda pública apropriada. Eles monitoram a atividade pública e privada e alertam a sociedade quando uma ideia prejudicial (segundo a sua perspectiva) é proposta. Assim como os partidos políticos, estes grupos promovem uma ligação entre os cidadãos e o governo (Weissert \& Weissert, 2002).

Os primeiros movimentos de redução de danos no Brasil surgiram no final dos anos 90. Nessa época, já havia alguns projetos-piloto de intervenção, financiados a partir de um estudo multicêntrico realizado pela OMS. A Associação Brasileira de Redução de Danos (Aborda), a Rede Brasileira de Redução de Danos (Reduc) e a Rede Latino-Americana de Redução de Danos (Relard) têm desempenhado um papel relevante na formação e no treinamento de profissionais para atuar nas atividades de campo, na sensibilização dos gestores locais para a implementação de estratégias e na pressão sobre políticos e gestores públicos visando à adoção de uma legislação de drogas menos repressiva. Além disso, existem aproximadamente 14 associações regionais, com finalidades similares, que dão suporte aos programas estaduais e municipais.

Diversos encontros são realizados todos os anos, reunindo os membros dessas associações, visando a discutir os rumos da política de drogas e a trocar experiências sobre diversas iniciativas desenvolvidas em todo país. Em 2001, um encontro promovido pelo PN DST/Aids e pelo escritório da UNODC Brasil, conhecido como Arena de Redução de Danos, reuniu vários especialistas e representantes da sociedade civil para discutir, entre outras questões, a necessidade 
de uma nova legislação sobre drogas. No mesmo ano, a Secretaria Nacional Antidrogas (Senad) aprovou o Plano Nacional Antidrogas, incluindo um capítulo sobre a importância das ações de redução de danos, e recursos do Fundo Nacional Antidrogas (Funad) foram alocados para a prevenção à Aids entre usuários de drogas (Interamerican Observatory on Drugs, 2002).

Os ativistas da redução de danos tiveram ainda uma participação importante na aprovação de diversas leis estaduais e municipais. A aprovação da primeira lei estadual teve lugar em São Paulo. Em 1997, um projeto que regulamentava as ações foi aprovado na Assembleia Legislativa, mas ficou aguardando a sanção do então governador Mario Covas, por seis meses. O período de realização da IX Conferência Internacional de Redução de Danos, em São Paulo, em 1998, que contou com a presença de profissionais, pesquisadores e do movimento de redução de danos internacional, foi o momento oportuno para pressionar o governador a aprovar a legislação:

Passamos as semanas anteriores à conferência pressionando o governador para que ele assinasse a lei. E reservamos o Palácio do Governo para a cerimônia de abertura da conferência. A conferência estava marcada para ter início no sábado à noite. O governador assinou a lei algumas horas antes, no sábado pela manhã. (Mesquita, 2003)

No ano seguinte, as ações de redução de danos foram regulamentadas no estado de Santa Catarina. Segundo Mesquita (2003), o governador de Santa Catarina estava sendo acusado de corrupção e aparecia constantemente na mídia:

Ele precisava de algo para distrair a mídia. Alguém [dando a impressão que ele mesmo, Fabio] sugeriu ao governador que se ele aprovasse uma lei que protegesse as ações de redução de danos e a troca de seringas para usuários de drogas, as pessoas e a mídia falariam disso por duas ou três semanas.

\section{Constrangimentos}

Há, no Brasil (como em diversos outros países), fatores que dificultam a adoção de políticas mais flexíveis e pragmáticas, por exemplo: a política de segurança pública (ao enfatizar a vertente de repressão), os movimentos de base religiosa e a violência estrutural que atemoriza os moradores dos centros urbanos, dificultando sobremaneira a proposição de uma agenda pública mais reflexiva e equilibrada dirigida às drogas. Apesar dos avanços, ainda existem 
(e muito provavelmente sempre existirão) defensores de uma política fundamentalmente ou exclusivamente repressiva.

As políticas de segurança nacional e estadual nem sempre estão de acordo com as proposições orientadas pela proteção e promoção da saúde pública. Por exemplo, o governo do Estado do Rio de Janeiro, durante a gestão do Secretário de Segurança Anthony Garotinho, em 2002, tinha uma posição conservadora com relação à questão. Mas, a despeito das diferentes medidas adotadas durante seu mandato, o problema da violência e do consumo de drogas não diminuíram no Estado.

A violência prejudica e mesmo impede a implementação de ações de redução de danos. Rhodes e colaboradores (2002) discutem o papel do contexto em que as ações de redução de danos são (ou não) implementadas. O argumento central dos autores é de que é preciso ir além da dimensão individual de avaliar os riscos e de que as estratégias para minimizá-los passam, necessariamente, pela dimensão contextual e social. Nesse sentido, Bastos e colaboradores (2007) relatam a dificuldade de implementar ações de saúde pública em favelas do Rio de Janeiro em face dos constantes conflitos entre facções rivais e entre facções criminosas e a polícia.

Além disso, a Igreja Católica, no Brasil, permanece como uma instituição de referência, capaz de propor valores no campo social e de promover ativamente suas posições. As ações de defesa dos direitos humanos, de luta em favor dos pobres, indígenas e marginalizados the confere grande credibilidade na sociedade, mesmo para os não católicos (Andrade, 2004), outorgando peso às suas posições sobre o aborto, o controle da natalidade e outros pontos polêmicos. Do mesmo modo, as ações desenvolvidas pela comunidade de evangélicos se mostram crescentemente influentes na sociedade brasileira. A posição explícita dessas instâncias a respeito das medidas de prevenção à Aids e a fração expressiva do eleitorado que apoia esses pontos de vista constituem um incentivo para que os políticos brasileiros defendam posições conservadoras como uma forma de angariar as simpatias e os votos desses eleitores.

\section{Conclusão}

Os tratados internacionais representaram uma resposta social e política dos países para a regulação do uso de drogas em um determinado período da história. A necessidade de se estabelecer uma ordem supranacional e de que 
se harmonizasse a questão culminou na aprovação das três convenções antidrogas. Uma vez traçado o rumo da política global, os custos implicados no rompimento das regras pactuadas ou mesmo na modificação dessa legislação podem ser muito elevados. A necessidade de se obter um consenso entre todos os países-membros da Comissão de Narcóticos das Nações Unidas torna ainda mais moroso esse processo.

Com a emergência da epidemia de Aids e a organização dos usuários de drogas, um novo cenário veio à tona na agenda política internacional. Diversos países enfrentaram e enfrentam epidemias que têm no uso compartilhado de drogas injetáveis elemento central à sua dinâmica, o que implica a adoção de medidas de saúde pública, desencorajadas e mesmo limitadas pelas convenções em vigor.

O Brasil tem tido uma participação importante nas arenas de debate internacional. Em particular, o Programa de Aids tem sido um importante formulador de sugestões inovadoras visando a contornar os limites impostos pelas regras internacionais. Ao longo dos últimos anos, o Brasil passou de receptor de ajuda a fornecedor de recursos e novas propostas. A doação do governo brasileiro, em 2006, ao Fundo Especial de Combate às Drogas e Crime foi a maior entre as de todos os doadores (principais e emergentes). Além disso, o escritório da UNODC no Brasil, em parceria com o Ministério da Saúde, tem investido amplamente nas ações de prevenção à Aids junto a usuários de drogas.

As convenções internacionais permitem aos países uma razoável margem de manobra. As principais instâncias definidoras da agenda das políticas públicas de drogas menos repressoras no Brasil têm sido o PN DST/Aids e o Ministério da Saúde de um modo geral (com papel relevante da Coordenação de Saúde Mental). O fato de contar com uma burocracia especializada e sensível aos riscos e danos associados ao compartilhamento de equipamentos de injeção potencialmente contaminados facilitou a adoção de medidas pragmáticas de saúde pública por parte dos gestores do Ministério da Saúde. A inserção de grupos de interesse nas instâncias decisórias do PN DST/Aids e o empréstimo contraído junto ao Banco Mundial permitiram o financiamento de ações de redução de danos em todo o país. O PN DST/Aids teve também grande influência na consolidação de uma coalizão de interesses em prol da redução de danos, que vem desempenhando um papel fundamental na aprovação de leis estaduais e na nova legislação federal sobre drogas.

Apesar dos avanços inegáveis da política nacional de drogas, ainda há muito para ser conquistado. Ainda tramita na Câmara dos Deputados o projeto 
de lei que regulamenta as ações de redução de danos. Há uma série de constrangimentos a serem vencidos, como resistências locais à plena implementação das políticas de redução de danos, provavelmente associados a descontinuidades e a recuos detectáveis no contexto da descentralização dessas ações (Fonseca et al., 2007).

Alguns fatores relevantes para a análise das políticas de drogas não foram discutidos aqui em detalhe, mas têm importância fundamental no funcionamento do sistema político e na implementação ou não de políticas públicas: a atuação dos diferentes partidos políticos, o Judiciário e o aparato policial, a opinião pública e a mídia. Por exemplo, o Partido dos Trabalhadores (PT) tem funcionado como um dos principais apoios das políticas de redução de danos. Porém, existem fissuras ideológicas relevantes no âmbito do próprio partido quanto a esses temas.

As possíveis mudanças da política de drogas constituem uma questão fundamental no mundo contemporâneo. O consumo de drogas é um 'problema' que gira em torno de questões morais controversas. Assim como a obesidade e o fumo, e de forma mais marcadamente moral, lidar com estilos de vida é sempre uma questão complexa e potencialmente polêmica. Apesar da ratificação, pelo conjunto das nações, das convenções das Nações Unidas, existem atualmente diferentes respostas para lidar com a questão das drogas - oscilando entre polos libertários e polos bastante conservadores. Quais os fatores envolvidos na adoção concreta dessas políticas em cada contexto? Quais as variáveis-chave a serem analisadas? De que maneira as políticas de drogas emergem na agenda política atual? O marco teórico-metodológico da ciência política contemporânea oferece uma gama de possibilidades a serem exploradas (Kingdom, 1995; Haas, 1992; March \& Olsen, 1989; DiMaggio \& Powell, 1991; Steinmo, Thelen \& Longstreth, 1992). O objetivo do presente texto foi tão somente lançar luz sobre esse complexo debate e propor novas linhas de investigação no Brasil. Muito há por se fazer, seja no campo da pesquisa, seja no campo das urgentes reformas de cunho prático e abrangência social.

\section{Referências}

ALLEN, D. The Cocaine Crisis. New York: Plenum Press, 1987.

ALLISON, G. \& ZELIKOW, P. Essence of Decision: explaining the Cuban missile crisis. 2. ed. New York: Longman, 1999. 
ANDRADE, P. A Igreja católica e o Estado brasileiro. In: AVELAR, L. \& CINTRA, A. (Orgs.). Sistema Político Brasileiro: uma introdução. Rio de Janeiro: Fundação Konrad-Adenanuer-Stiftung; São Paulo: Fundação Unesp, 2004.

BASTOS, F et al. The children of mama coca: coca, cocaine and the fate of harm reduction in South America. International Journal of Drug Policy, 18: 99-106, 2007.

BECKERLEG, S.; TELFER, M. \& SADIQ, A. A rapid assessment of heroin use in Mombasa, Kenya. Substance Use Misuse, 41(6-7): 1.029-1.044, 2006.

BELLIS, D. Heroin and Politicians: the failure of public policy to control addiction in America. Connecticut: Greenwood Press, 1981.

BERRIDGE, V. \& EDWARDS, G. Opium and the People. New York: Allen lane/St Martin`s Press, 1981.

BEWLEY-TAYLOR, D. Challenging the UN drug control conventions: problems and possibilities. International Journal of Drug Policy, 14: 171-179, 2003.

BRASIL. Lei 6.368, 21 out. 1976. Dispõe sobre medidas de prevenção e repressão ao tráfico ilícito e uso indevido de substâncias entorpecentes ou que determinem dependência física ou psíquica, e dá outras providências. Diário Oficial da União, Brasília, 1976.

BRASIL. Lei 10.409, 11 jan. 2002. Institui o Código Civil. Diário Oficial da União, Brasília, 2002.

BRASIL. Lei 11.343, 23 ago. 2006. Institui o Sistema Nacional de Políticas Públicas sobre Drogas - Sisnad; prescreve medidas para prevenção do uso indevido, atenção e reinserção social de usuários e dependentes de drogas; estabelece normas para repressão à produção não autorizada e ao tráfico ilícito de drogas; define crimes e dá outras providências. Diário Oficial da União, Brasília, 2006.

BRASIL. Projeto de lei federal n. 1.279. Dispõe sobre o fornecimento de seringas e agulhas descartáveis e esterilizadas em centros e entidades de tratamento e recuperação de usuários de drogas credenciados. Câmara dos Deputados, Brasília, 1999.

BRASIL/MINISTÉRIO DA SAÚDE. Portaria n. 1.028, 4 jul. 2005. Determina que as ações que visam à redução de danos sociais e à saúde, decorrentes do uso de produtos, substâncias ou drogas que causem dependência, sejam reguladas por esta Portaria. Diário Oficial da União, Brasília, 2005.

BYCK, R. (Ed.). The Cocaine Papers by Sigmund Freud. Nova York: Plume, 1975.

COSTA, V. Federalismo: as relações intergovernamentais. In: AVELAR, L. \& CINTRA, A. (Orgs.). Sistema Político Brasileiro: uma introdução. Rio de Janeiro: Fundação Konrad-Adenanuer-Stiftung; São Paulo: Fundação Unesp, 2004. 
DE QUINCEY, T. Confessions of an English Opium-eater. Oxford:Oxford University Press, 1998.

DECLARAÇÃO DE VIENA. Redução de danos como estratégia de saúde pública: intervenção brasileira. In: Sessão de Viena - 13 a 17 mar., 49, 2006, Viena. Disponível em: $<$ www.aids.gov.br/data/documents>. Acesso em: 13 mar. 2006. (Documento apresentado na Comissão de Drogas Narcóticas)

DIMAGGIO, P. \& POWELL, W. (Eds.). The New Institutionalism in Organizational Analysis. Chicago: University of Chicago Press, 1991.

DUARTE, D. Uma breve história do ópio e dos opioides. Revista Brasileira de Anestesiologia, 55(1): 135-146, 2005.

EUROPEAN NETWORK FOR HIV/AIDS SURVEILLANCE (EUROHIV). HIV/Aids Surveillance in Europe: end-year report 2005. Saint-Maurice: Institut de Veille Sanitaire, 2005. (Endyear Report, 73)

FAZEY, C. The Commission on Narcotic Drugs and the United Nations International Drug Control Programme: politics, policies and prospect for change. International Journal of Drug Policy, 14: 155-169, 2003.

FONSECA, E. \& BASTOS, F. Políticas de redução de danos em perspectiva: comparando as experiências americana, britânica e brasileira. In: ACSELRAD, G. (Org.). Avessos do Prazer: drogas, Aids e direitos humanos. 2. ed. Rio de Janeiro: Fiocruz, 2005.

FONSECA, E. et al. Syringe exchange programs in Brazil: preliminary assessment of 45 programs. Cadernos de Saúde Pública, 22(4): 761-770, 2006.

FONSECA, E. et al. Descentralização, Aids e redução de danos: a implementação de políticas públicas no Rio de Janeiro, Brasil. Cadernos de Saúde Pública, 23(9): 21342144, 2007.

HAAS, P. Introduction: epistemic communities and International Policy Coordination. International Organization, 46(1): 1-37, 1992.

JONAS, D. F. \& JONAS, A. D. A bioanthropological overview of addiction. In: NATIONAL INSTITUTE ON DRUG ABUSE (NIDA). Research Monograph, 30: 269-277, 1980.

KARAM, M. L. Redução de danos, ética e lei. In: SAMPAIO, C. \& CAMPOS, M. (Orgs.). Drogas, Dignidade \& Inclusão Social: a lei e a prática de redução de danos. Rio de Janeiro: Aborda, 2003.

KERR, T. et al. Opioid substitution and HIV/Aids treatment and prevention. The Lancet, 364(9.449): 1.918-1.919, 2004.

KERR, T. et al. Safer injection facility use and syringe sharing in injection drug users. The Lancet, 366(9.482): 316-318, 2005. 
KINGDOM, J. Agendas, alternatives and public policies. 2. ed. New York: Harper Collins College Publishers, 1995.

INTERAMERICAN OBSERVATORY ON DRUGS. Fortalecimento institucional/estratégia nacional antidrogas - 2002. Disponível em: <www.cicad.oas.org/OID/Countries/Brasil/ MEM/Brasil01-02PORT.pdf>. Acesso em: 29 maio 2007.

JOINT UNITED NATIONS PROGRAMME ON HIV/AIDS (UNAIDS). Report on the Global Aids Epidemic. Geneva: Unaids, 2006.

LEVINE, H. Global drug prohibition: its uses and crises. International Journal of Drug Policy, 14: 145-153, 2003.

MARCH, J. \& OLSEN, J. Rediscovering Institutions: the organizational basis of politics. New York: Free Press, 1989.

MARCH, J. C. et al. Controlled trial of prescribed heroin in the treatment of opioid addiction. Journal of Substance Abuse and Treatment, 31(2):203-211, 2006.

MCCURDY, S. A. et al. HIV/Aids and injection drug use in the neighborhoods of Dar es Salaam, Tanzania. Drug Alcohol Depend, 82 (Suppl 1):S23-27, 2006.

MESQUITA, F. Fabio Mesquita no limiar da vitória. Narconews, 2003. Disponível em: <www.narconews.com/Issue30/artigo780.html> Acesso em: 27 maio 2007.

NARCONEWS. Lula: a guerra das drogas é uma guerra de classes. Narconews, 29 abr. 2003. Disponível em:<www.narconews.com/Issue30/artigo773.html>. Acesso em: 29 maio 2007.

NUNN, A. The Politics of Life and Death: historical institutional analysis of antiretroviral drug policy in Brazil, 2007. Tese de Doutorado, Boston: Harvard School of Public Health, Harvard University.

OSMANCZYK, E. The Encyclopedia of the United Nations and International Relations. 2. ed. London:Taylor \& Francis, 1990.

PAGE, E. Political Authority and Bureaucratic Power: a comparative analysis. Knoxville: University of Tennessee Press, 1985.

PROGRAMA NACIONAL DE DST E AIDS (PN DST/AIDS). Brasil reafirma eficácia da política de redução de danos como estratégia de saúde pública, 2006. Disponível em:<www. aids.gov.br/data/Pages/LUMISE77B47C8ITEMIDD447BD52D2FE4FD493F5F7E0CEB8309FPTBRIE.htm>. Acesso em: 29 maio 2007.

RHODES, T. et al. Explosive spread and high prevalence of HIV infection among injecting drug users in Togliatti City, Russia. Aids, 16(13): F25-31, 2002.

SCHEERER, S. Estabelecendo o controle sobre a cocaína. In: BASTOS, F. I. \& GONÇALVES, O. D. (Orgs.). Drogas: é legal? Um debate autorizado. Rio de Janeiro: Imago Editora, 1993. 
STEIN, E. et al. The politics of policies: economic and social progress in Latin America. New York: Inter-American Development Bank, 2005.

STEINMO, S.; THELEN, K. \& LONGSTRETH, F. (Eds.). Structuring Politics: historical institutionalism in comparative perspective. Cambridge: Cambridge University Press, 1992.

STIMSON, G. UN Commission on Narcotic Drugs: 50th session. UK intervention on agenda item 5(b): world situation with regard to drug abuse. Disponivel em: <www.ihra. net/uploads/downloads/NewsItems/CND2007SpeechGStimson.pdf>. Acesso em: 29 maio 2007.

UNITED NATIONS OFFICE ON DRUGS AND CRIME (UNODC). Marco Estratégico-UNODC Brasil - 2006-2009. ago. 2006a. Disponível em:<www.unodc.org/pdf/brazil/portugues_final2.pdf>. Acesso em: 29 maio 2007.

UNITED STATES CENTERS FOR DISEASE CONTROL AND PREVENTION (CDC). Twenty-five years of hiv/aids - United States, 1981-2006. Morbidity and Mortality Weekly Report, 55(21): 588-605, 2006b.

UNITED NATIONS OFFICE ON DRUGS AND CRIME (UNODC). About us. <www.unodc.org/ unodc/en/about.html>. Acesso em: 29 maio 2007a.

UNITED NATIONS OFFICE ON DRUGS AND CRIME (UNODC). Annual Report - 2006. Disponível em:<www.unodc.org/pdf/annual_report_2007/AR06_fullreport.pdf>. Acesso em: 29 maio $2007 \mathrm{~b}$.

WEIR, E. Raves: a review of the culture, the drugs and the prevention of harm. Canadian Medical Association Journal, 162(13): 1.843-1.848, 2000.

WEISSERT, C. \& WEISSERT, W. Governing Health: the politics of health policy. 2. ed. Baltimore:The Johns Hopkins University Press, 2002.

WOlFE, D. \& MALINOWSKA-SEMPRUCH, K. Illicit Drug Policies and the Global HIV Epidemic: effects of UN and National Government Approaches. New York: Open Society Foundations, 2004.

WORLD HEALTH ORGANIZATION (WHO). World Health Report. Geneva: WHO, 2006.

WORLD BANK. Confronting Aids. New York: Oxford University Press, 1999.

WORLD BANK. Committing to Results: improving the effectiveness of HIV/Aids assistance. Washington DC:World Bank, 2005. 


\title{
A Síndrome de Elêusis:
}

\section{considerações sobre as políticas públicas no campo de atenção ao usuário de álcool e outras drogas}

\author{
Sergio Alarcon
}

\begin{abstract}
Atrás das coisas há algo 'inteiramente diferente': não seu segredo essencial e sem data, mas o segredo que elas são sem essência, ou sua essência foi construída peça por peça a partir de figuras que Ihe eram estranhas. (...) 0 que se encontra no começo histórico das coisas não é a identidade ainda preservada da origem - é a discórdia das coisas, é o disparate.
\end{abstract}

Michel Foucault

Há mais de dois mil anos, o templo de Elêusis, na antiga Grécia, era o centro espiritual e místico mais importante da cultura helenística. Nele celebravam-se os mistérios dedicados a três deuses ctônicos - Deméter e o ciclo da vida e da morte; Dionísio e a transgressão dos prazeres do corpo; e Orfeu e o desejo de purificação e ascese da alma.

Etimologicamente, mistério significa 'coisa secreta', 'ação de calar a boca', e o pouco que se sabe a respeito dos mistérios de Elêusis se refere, em especial, ao uso das chamadas 'plantas mágicas'. Além do ópio (do grego opion, suco), recolhido das sementes da papoula branca - planta que, aliás, ornava as estátuas de Deméter -, vários psicoativos eram consumidos nos ritos de iniciação que banharam em êxtase toda a espiritualidade do mundo clássico.

Dos ritos sabe-se também que eram ensinamentos que permitiam aos adeptos repetirem o caminho do trágico e pungente eterno retorno das forças vitais que germinam a terra e que era revelado apenas aos que juravam mantê-lo em segredo. No templo de Elêusis, por milhares de anos, a emanação invisível da vida e da morte foi intuída na sintaxe inebriante das drogas.

Nos dias de hoje, as 'plantas mágicas' (e seus derivados sintéticos) se mantêm como suporte de mistérios - de vida e morte; prazeres e ascese; e, em todos os espaços, sejam eles públicos ou privados, as drogas motivam discussões 
apaixonadas sobre sua proscrição ou aquiescência. Trabalhos científicos tentam avaliar o crescimento do consumo, a magnitude dos malefícios, a redução dos riscos e danos, a faixa etária em que o uso prevalece etc. Programas de repressão, cada vez mais sofisticados, procuram extinguir a circulação de certas drogas, ao mesmo tempo que elegias ao mundo das viagens enteógenas ${ }^{1}$ clamam pela paz e por uma regulação racional (Esteban, 2007).

É certo que, de muitas formas e na maioria das vezes, perde-se o fio da meada e deixa-se de ter o domínio sobre as causas que sustentam o modo com que determinadas relações com as drogas são expressas na sociedade. A perda da capacidade de agir sobre essas causas favorece distorções que condicionam o recrudescimento dos efeitos dramáticos do uso de drogas, em especial quando nos deparamos com aqueles aos quais chamamos de dependentes químicos. O fato é que temos, no âmbito da saúde pública, que agregar esforços para tornar possível uma resposta satisfatória aos malefícios engendrados pelo 'problema-drogas' - termo utilizado aqui para que não resumamos as relações com as drogas simplesmente aos danos que elas podem causar no organismo humano em virtude do eventual uso inadequado, mas também aos danos produzidos por todas as consequências inerentes às políticas antidrogas, à cultura da violência que lhe é subjacente e que perdura, paradoxalmente, em nome da saúde da população.

Sobre as intervenções do setor saúde em relação às drogas, sabemos que se baseiam essencialmente na certeza dos danos provocados pelo seu uso, tendo como modelo universal as demandas produzidas pelos efeitos da dependência química. Essa certeza, por sua vez, é baseada na hegemonia de uma perspectiva que parece não admitir a possibilidade do uso de drogas como parte de um estilo individual e privado compatível com o incremento da qualidade de vida. Isso fica claro, por exemplo, quando nos deparamos com as ações preventivas que, via de regra, utilizam palavras de ordem 'antidrogas', visando a reduzir a demanda.

Da mesma forma, tomar como modelo universal a dependência química é reduzir as relações possíveis com as drogas a um tipo de acontecimento em geral incomum e minoritário, distorcendo a magnitude dos agravos decorrentes do uso. No entanto, sabe-se que as 'evidências' a respeito dos agravos são demarcadas por determinações jurídico-policiais, ou seja, derivadas

\footnotetext{
Palavra de origem grega que quer dizer "tornar divina a própria interioridade" mediante o êxtase induzido pelo uso de substâncias modificadoras da consciência.
} 
de pontos de vista excêntricos à constituição de verdadeiras evidências epidemiológicas. Em que pesem as histórias de vida infame associadas aos 'drogados' serem reais, essa realidade não pode ser considerada unicamente com base nos efeitos farmacológicos colaterais produzidos pelo uso de drogas, assim como essa realidade não pode ser dissociada do próprio contexto das relações entre o setor saúde e a lógica proibicionista. ${ }^{2}$ Por certo, são justamente as relações entre o setor saúde e o de segurança (tecidas pela lógica proibicionista) que se mantêm como um segredo ${ }^{3}$ mais bem guardado que os mistérios eleusianos. Relações que confundem a formulação de novas políticas sanitárias que busquem reduzir a potência venenosa ou tóxica não apenas das moléculas farmacológicas, mas, em especial, das relações nas quais essas moléculas são inseridas.

Tentar desvendar esse mistério equivale a achar um tesouro escondido, uma chave que destranca a saída para uma série de contradições. Certamente não se trata de tarefa simples, nem teríamos a pretensão de realizá-la aqui. Para se ter uma ideia de sua dimensão, teríamos que proceder a estudos genealógicos diferenciais, como um olhar sobre a geopolítica internacional configurada a partir do século XVIII, sobre as lutas pela conquista de mercados, o velho e o novo imperialismo. Teríamos que nos deter também sobre as novas tecnologias de produção de corpos dóceis e úteis ao trabalho, determinadas pelo capitalismo nascente (Foucault, 1985). Enfim, seria necessário percorrer todo um labirinto macro e micropolítico de pouco menos de duzentos anos, onde está guardado e escondido o fio de Ariadne que nos encaminharia na direção dos interesses de cada movimento realizado desde o início por alguns países centrais, que esperaram antes de tudo lucrar com essa peculiar tendência humana de investir no desejo e obter prazer pelo atalho das drogas. De forma imprecisa, podemos dizer, apenas para começar a tatear pelo caminho secreto de Ariadne, que foi a partir das consequências inerentes à Revolução Burguesa e Industrial, conjugadas em especial ao boom das indústrias farma-

\footnotetext{
2 Entenda-se por 'proibicionismo' o uso da força simbólica e direta do Estado para terminar ou estancar determinado tipo de comportamento em nome de tradições moralistas e em detrimento de princípios básicos do direito, como o de prudência e o da proporcionalidade (Dores, 2004).

3 Em História da Sexualidade I: a vontade de saber (1985), Foucault pergunta-se, a certa altura, como seria possível ao poder de interdição - que ele denomina jurídico-discursivo - produzir com eficácia os efeitos de obediência. Aventa, então, a hipótese da função tática geral do segredo. O segredo é o limite traçado à liberdade pelo poder jurídico-discursivo e envolve o próprio funcionamento das táticas de adesão das consciências ao seu discurso niilista (que desqualifica, por exemplo, a liberdade do outro, tornando-a um 'risco').
} 
cêuticas e ao início da produção maciça de psicoativos - eventos ocorridos entre os séculos XVIII e XIX -, que o padrão ancestral, comunitário e ritualístico de uso de drogas encontrou condições materiais para transformar (ou melhor dizendo, inventar') essas relações que foram denominadas, talvez de forma apressada, "toxicomanias de massa" (Koutousis \& Perez, 1996).

Diante de tal cenário, já é possível entrever a suspeita de que a repressão globalizada não está diretamente relacionada com os reais interesses em salvaguardar a saúde dos indivíduos e das populações. Com base nessa suspeita, é justo supor que o proibicionismo se sustenta por seu duplo elo, constituído, de um lado, pelo discurso sanitário, e, de outro, pelo discurso criminológico. Em outras palavras: o proibicionismo sustenta-se, ao mesmo tempo, pela busca 'moralizada' de saúde (a saúde a qualquer preço), pela 'desmoralização' jurídico-policial do usuário de drogas e, com maior intensidade ainda, pela 'demonização' da substância em si (termo médio que faz a ligação lógica entre um elo e outro).

\section{Proteção à Saúde e Proibicionismo}

A motivação sanitária desde muito tempo tem sido o principal subterfúgio para a implantação de leis proibicionistas em relação à utilização de certas drogas, ${ }^{4}$ constituindo-se, ainda hoje, no primeiro argumento daqueles que defendem a manutenção dessas mesmas leis. Contudo, uma das questões mais embaraçosas do problema-drogas está no dilema expresso na dimensão intrínseca aos eventuais danos (orgânicos) produzidos pelo uso de psicotrópicos quando comparados aos danos provocados pelos mecanismos de gestão de riscos, expressos especialmente no combate ao comércio ilegal de drogas e ao uso de drogas ilícitas.

De antemão, sabemos que o risco se relaciona à possibilidade de que um evento possa ocorrer, enquanto o dano deve ser visto como a ocorrência do pró-

\footnotetext{
4 As drogas são proibidas não por sua natureza, mas por decisão política. No Brasil, é o Executivo que determina, por intermédio do Ministério da Saúde, quais são essas substâncias, em consonância com as normas emanadas pelos acordos internacionais sobre a questão. Drogas como o THC (Delta 9-tetrahidrocanabinol) da Cannabis sativa (maconha, haxixe), o cloridrato de cocaína (2-beta-carbometoxi-3-betabenzoxitropano) e o MDMA ou ecstasy (3,4-metilenodioximetanfetamina) continuam proibidas em virtude da adesão do Brasil aos tratados internacionais que consideram essas drogas portadoras de risco de dano à sociedade.
} 
prio evento e seus efeitos/desdobramentos. Ou seja, em uma situação de risco nem sempre ocorre necessariamente um dano, e no controle dos riscos não está implícita a sua anulação, na medida em que a noção de risco é, em geral, apenas a projeção pessimista de um incerto acontecimento futuro. Na verdade, o que uma prática de controle de riscos prescreve, na maioria das vezes, são ações capazes de diminuir ao máximo a probabilidade de um evento danoso acontecer. Mas quando esse controle busca apenas, de maneira inflexível, anular os riscos sob a pretensão de extinguir completamente os danos, o seu caráter necessariamente incerto pode tornar-se, ao mesmo tempo, uma obsessão pelo controle total. Observa-se aqui a construção do que pode ser chamado de 'moral neopreventivista', que almeja nada menos que o controle absoluto de seu objeto: um tipo de higienismo que promove a saúde por não suportar a mera possibilidade dos danos e que, no final das contas, sustenta as políticas de gestão de riscos, conhecidas comumente como 'antidrogas', que são preferencialmente de combate e repressão. Essa moral neopreventivista carrega consigo, para legitimar a pertinência do controle absoluto, a crença de que existe uma suposta necessidade causal na relação entre uso de drogas e danos, de maneira que, ao identificar a causa do risco à existência das drogas, supõe também ser possível extinguir os danos eliminando a causa desses riscos, ou seja, eliminando as drogas.

Por isso, o foco do controle recai preferencialmente sobre a droga 'em si', que, de ente inanimado, é elevada à categoria de 'agente' de riscos para a sociedade (portanto, é apenas de forma secundária e acessória que se pensa sobre as causas complexas que motivam o seu uso e a eventual dependência).

Assim, geralmente encontramos como principal argumento e motivo para as medidas restritivas e repressivas a proteção à saúde, seja do corpo individual, seja do corpo social. Esse argumento geral circula de forma incontestável tanto entre especialistas quanto no corpo das leis internacionais que instituíram (através de leis nacionais) a proibição de certas drogas nos diversos países signatários da Convenção Única de 1961 sobre Estupefacientes (ou seja, quase todas as nações do planeta). A essência desse argumento é a suposição de que as drogas ilícitas oferecem não apenas riscos, mas necessariamente danos. O advérbio 'necessariamente' é o não dito retórico que nos faz esquecer do caráter casual (intraduzível em termos probabilísticos) ${ }^{5}$ desse argumento. Trata-se

\footnotetext{
5 Na medida em que a possibilidade de risco não é passível de rigorosa mensuração, obedecendo apenas o princípio da precaução, onde a incerteza do risco é que determina as decisões
} 
apenas de um efeito discursivo cujo moralismo implícito ajudou a torná-lo a 'verdade' incontestável da antiga Lei de Entorpecentes n. 6.368, sancionada em 21 de outubro de 1976 (em plena ditadura militar), vigente por trinta anos, que criminalizou o tráfico de entorpecentes (artigo 12 - considerado crime hediondo segundo a lei n. 8.072/90, punindo o porte para uso pessoal (artigo 16). A nova Lei de Entorpecentes (lei n. 11.343/2006), sancionada em meados de 2006, mesmo tendo acabado com a prisão para usuários de drogas, que passaram a ser submetidos a penas alternativas, como advertência e prestação de serviços, continua criminalizando usuários e dependentes químicos, mantendo-os sob vigilância e tutela punitiva.

\section{O Mistério Encoberto pelo Imperativo Sanitário}

No caso da hipótese de risco de dano à sociedade, o mais direto e o de maior impacto dramático deveria se referir à possibilidade de óbitos por overdose. No Brasil, não há dados quantitativos confiáveis para se aferir a gravidade e a magnitude desse evento danoso, o que nos obriga a buscar alhures parâmetros para a avaliação do risco.

Segundo relatório do Observatório Europeu das Drogas e da Toxicodependência (OEDT, 2003), nos dez anos anteriores ao da publicação da pesquisa em 2003, o número total anual de óbitos por intoxicação aguda relacionada ao consumo de drogas reportado por países da União Europeia e Noruega oscilou entre sete e nove mil pessoas. Esses números incluem a intoxicação por heroína, responsável por cerca de $70 \%$ desses óbitos - droga cujo uso é estatisticamente irrelevante no caso brasileiro. Ou seja, a julgar pelos dados europeus (que são grandes consumidores mundiais de psicoativos e que possuem uma população cerca de duas vezes superior à brasileira), a mortalidade diretamente vinculada ao uso de drogas ilícitas não é, como se pensa comumente, catastrófica, especialmente se a compararmos com outras causas de morbimortalidade que a saúde pública elenca como relevantes.

Quanto à aferição do quantitativo de pessoas que ao longo da vida experimentaram drogas, ou sobre o consumo recente de substâncias psicoativas, o Brasil está entre os países de menor consumo relativo de psicoativos do planeta, como mostra o World Drug Report divulgado em 2004 pelo Escritório das

e os cálculos de probabilidade não almejam nada de bom, apenas se escapar do pior. 
Nações Unidas contra Drogas e Crime (UNODC). Enquanto a droga mais consumida no mundo, a maconha, é utilizada no Brasil por 1\% da população, na Espanha essa taxa é de 9,7\%, no Reino Unido, de 10,6\% e nos Estados Unidos, de $11 \%$. O Brasil, segundo o relatório, é também um dos países onde menos se consome cocaína, mesmo sendo o país vizinho do único espaço terrestre onde a folha de coca pode ser cultivada (os Andes e seus vales). De acordo com o mesmo relatório, $0,4 \%$ da população brasileira utiliza esse tipo de droga, enquanto na Espanha - em termos relativos, a maior consumidora mundial - essa taxa é de 2,6\%, e, nos Estados Unidos, fica em 2,5\%. Assim, mesmo com os incrementos constatados a partir das décadas de 1980 e 1990 quanto ao consumo de maconha e cocaína, o Brasil não figura entre os países de maior consumo de drogas ilícitas (UNODC, 2003).

Com relação à identificação das substâncias proibidas como entidades produtoras de situações criminosas, é senso comum afirmar que o aumento da violência nas grandes cidades brasileiras se deve especialmente ao incremento do uso de drogas. Sobre isso, em 2002, o Instituto Brasileiro de Geografia e Estatística (IBGE) divulgou estudos afirmando que, entre 1980 e 2000 - mesmo período no qual o Brasil se tornou 'rota' do tráfico internacional de drogas e consolidou esse papel (Misse, 2003) -, a taxa de mortalidade por homicídios aumentou 130\%, chegando a seiscentos mil óbitos - quase o dobro do total de vítimas letais nas três décadas em que durou a guerra civil angolana (IBGE, 2002). Contudo, antes de associar diretamente a causa da violência ao uso, o próprio UNODC (2003) reconhece implicitamente a importância de se avaliar, no caso brasileiro, as relações entre o tráfico de drogas e o de armas, reafirmando os dados divulgados pelo IBGE que registram em torno de trinta mil homicídios anuais no país. Calcula-se que esse número, somado aos casos presumidos não registrados, resultaria em uma cifra aproximada de cinquenta mil mortes em 2001, número três vezes superior à média mundial.

A esse respeito, é reveladora a declaração de Giovanni Quaglia, representante do UNODC, afirmando que aproximadamente quinze mil jovens brasileiros perdem suas vidas anualmente por causa da guerra decorrente do tráfico de drogas (Quaglia, 2008a, 2008b). Como as drogas, apesar de certo alarmismo, não são responsáveis diretamente pela posse e pelo uso de armas, e como o uso de drogas também não possui vínculo causal necessário com a produção da violência física - especialmente as organizadas endemicamente -, a motivação que produz a morte de quinze mil jovens, em média, por ano, deve ser buscada 
alhures, talvez em um processo insidioso de extermínio de uma população específica, sob o pretexto de salvaguardar a saúde dessa mesma população, o que está diretamente relacionado às ações de repressão à oferta e demanda de drogas tornadas ilícitas. Verificando minimamente a viabilidade dessa suposição, observa-se nas pesquisas que o perfil das vítimas preferenciais dessa violência confirma, por sua vez, os dados de Quaglia: o grupo mais afetado é composto por indivíduos do sexo masculino (proporção de 3:1 em relação às mulheres), geralmente negros ou pardos, das classes populares, na faixa etária entre 15 e 29 anos, moradores das regiões metropolitanas e favelas dos grandes centros urbanos (IBGE, 2002).

Há realmente fortes indícios de que a violência comumente vinculada ao problema-drogas afeta de modo inequívoco adolescentes e jovens pobres ou, em outras palavras, aqueles para os quais as ações do poder público são restritas e, em geral, também violentas - em uma equação que conjuga o mito da 'certeza da impunidade' (na verdade, o Brasil possui a maior população carcerária do hemisfério Sul e a segunda maior do planeta) com uma distribuição racista do que nossa sociedade entende por direitos humanos (Coimbra, 2003).

De imediato podemos nos perguntar, em primeira análise, o que justificaria a quantidade de homicídios no Brasil diretamente vinculada à guerra às drogas se não somos nem grandes produtores nem grandes consumidores. Questão cuja resposta parece não poder ser tão facilmente referida ao simples uso de drogas, especialmente se compararmos nossa situação com a da Europa e dos EUA, lugares em que se consome uma quantidade infinitamente maior de psicoativos - inclusive os ilegais -, mas onde não se morre nem se mata tanto por causa da guerra às drogas. Tudo isso nos obriga a mostrar, em uma segunda análise - seguindo os dados do IBGE e do UNODC -, a urgência de se atentar para as relações entre comércio ilícito, sua repressão e as legislações que 'instituem' a ilicitude como uma das principais causas da atual violência urbana brasileira, motivada por pressões estrangeiras, vinculadas diretamente às legislações internacionais antidrogas. Como essas legislações são histórica e politicamente sustentadas por países da Europa Ocidental e dos EUA, é como se cada um desses governos nos houvesse declarado uma guerra em segredo, sem que nos apercebêssemos do que se trata além das consequências em termos de danos. Ou, pior ainda, é como se, masoquistas e suicidas, nos aliássemos a nossos predadores para exterminarmos a nós mesmos, pois, mesmo que se diga que os tratados foram emanados de corpos diplomáticos - que jamais consultam os reais interessados, nem como cidadãos nem como técnicos da área -, tudo acontece como se, inermes, 
fôssemos incapazes, como sociedade, de produzir qualquer resistência à "tolice"6 das crenças proibicionistas.

\section{Círculo Vicioso das Políticas Públicas}

Regida pelo espectro do controle internacional antidrogas, toda uma subcultura se desenvolveu no Brasil, unindo uma gama de ações aparentemente contraditórias, mas no fundo dependentes umas das outras, que transformaram as drogas no ponto central de sua racionalidade. Nessa subcultura podemos incluir uma série de acontecimentos, como o tráfico de armas, a criminalização da pobreza, a produção de insegurança, a obsessão por segurança, além, é óbvio, do sistema da dependência abjeta, "dependência com relação ao produto, à posse, às produções fantasmagóricas, dependência com relação ao fornecedor" (Deleuze, 1991:65).

Especificamente, no âmbito da saúde pública, a cada dia torna-se mais premente agregar esforços para tornar possível uma resposta satisfatória às questões engendradas pelo problema-drogas. No entanto, a incapacidade de agir sobre as verdadeiras causas (o proibicionismo seria aqui causal) favorece distorções que condicionam o recrudescimento dos efeitos dramáticos do uso abusivo e da dependência de psicoativos. Produz-se, então, um círculo vicioso no qual um acontecimento com base factual escassa ou equivocada (a interpretação corrente de que existem drogas más) é provado, reafirmado e mantido como um fantasma aterrador pelo próprio mecanismo produtor do suposto fato.

6 No sentido dado ao termo, por Gilles Deleuze, em Diferença e Repetição (2006): o grande problema para o pensamento não é de fato o erro ou as condições de possibilidade do juízo verídico, mas a tolice, da qual deve constantemente fugir para tornar possível pensar o novo. No nosso caso, trata-se aqui de se avaliar até que ponto as ações proibicionistas, ainda que sustentadas por afirmações lógica e cientificamente verdadeiras, não resultam, mesmo assim, em iniquidades. Por exemplo, se é certo que, do ponto de vista farmacológico, a cocaína pode favorecer riscos, disso não se pode concluir serem esses riscos nem absolutos, nem incontroláveis. A supervalorização de uma verdade, ou seja, os riscos inerentes ao uso da cocaína por um indivíduo, traduz-se então em uma tolice: a proibição total do uso. Como resultado, não se observa a proteção do indivíduo exposto ao risco, mas sim a constituição de um mercado negro e incontrolável, do tráfico, cuja violência é diretamente proporcional à repressão, e a criminalização daquele usuário, motivo da ação pretensamente protetiva. É a tolice - e não o erro - que sustenta a passagem do controle do risco individual para o dano social como resultado. Parodiando Melville, posto que a tolice se nutre do coração e não do cérebro, nenhum grau de inteligência oferece garantia contra ela... 
Assim, em se tratando, por exemplo, das relações entre a política pública sustentada pelo Ministério da Saúde para a atenção ao usuário de álcool e outras drogas (Brasil/MS, 2003) e da legislação de entorpecentes aplicada pelo setor de segurança pública, pode-se dizer que a criminalização do usuário acaba por se refletir em um campo de atenção ao dependente químico que é conflitivo e paradoxal. Se por um lado, na perspectiva da saúde pública, o controle dos efeitos danosos do uso abusivo e patológico é a única forma de combate às drogas, uma vez que o seu uso não pode ser abolido por decreto, por outro lado o setor de segurança acaba induzindo medidas que têm como horizonte o ideal de uma sociedade sem drogas, privilegiando o combate ao comércio ilegal e tornando secundário o controle sobre os efeitos de um uso eventualmente inadequado. Nessa perspectiva, confere-se mais importância às ações de redução da demanda, gerando, por exemplo, a crença de que o único tratamento possível é o que prescreve a abstinência total. Mas, se aqui se percebe, superficialmente, uma dicotomia e até uma contradição, na verdade, ao perscrutarmos as profundezas dessas relações intersetoriais (saúde-segurança), verificaremos a existência de um acordo secreto, que mantém as drogas como entidades metafísicas, maléficas em todo caso, fazendo-nos, consequentemente, esquecer de que, como já dizia Paracelso, ${ }^{7}$ o veneno está na dose, e não na substância 'em si': "dosis sola facit venenum".

Portanto, se é óbvio que o setor segurança combate as drogas para extingui-las, o setor saúde, de certa maneira, também assume, em diversos momentos, o mesmo papel de 'combate' às drogas. Vê-se isso, por exemplo, nas campanhas publicitárias lançadas em 2009 pelo Ministério da Saúde 'contra' o crack, ${ }^{8}$ que, insidiosamente, repetem os bordões antidrogas, ao invés de propor uma nova abordagem do problema visando à construção de uma paideia ${ }^{9}$ para as relações possíveis com as drogas (mesmo apesar das aporias inerentes à dependência química). Esse tipo de campanha, cuja estratégia é dramatizar os efeitos danosos produzidos pelo uso equivocado, tende a incitar, como colocam Bucher e Oliveira (1994), a "cruzada antidrogas", cuja

\footnotetext{
7 Médico e alquimista da época renascentista, considerado o fundador da bioquímica.

8 A campanha teve início dia 16 de dezembro de 2009 e foi veiculada em jornais, revistas, emissoras de TV e cinemas até o dia 31 de janeiro de 2010. Teve como slogan o mote "Nunca experimente o crack. Ele causa dependência e mata". Em um dos comerciais, havia uma locução com um fundo preto e branco, pedindo a atenção dos telespectadores e repetindo o slogan mencionado. Em outro comercial, era contada a história de um rapaz que roubou a própria família para consumir o crack.

9 No sentido de um "aprendizado".
} 
beligerância contribui decisivamente para a expansão do fenômeno de uma repressão implacável, restrita às drogas ilícitas, embora se saiba serem as substâncias lícitas as mais consumidas e as mais fortes geradoras de abusos e dependências no Brasil. Não seria então mera conjectura admitir que essa disposição condenatória das drogas influencia a redução da complexa clínica da toxicomania ao mero assistencialismo e acaba por tornar também restrita (pois concebida ipsis litteris) a política de redução de danos anunciada pelo próprio setor saúde.

O que se critica aqui não é, obviamente, certa ideia de redução de danos, mas o fato de a política pública estar sendo implantada aparentemente sem problematizar as diversas maneiras de relação possíveis (saudáveis ou não) entre o homem e suas drogas. O risco, sem trocadilhos, é levar ao pé da letra a crença hegemônica de que, em relação às drogas, só nos restam ações de redução de danos, como se ao uso de drogas correspondesse, necessariamente, o dano. Desse ponto de vista, entende-se por dano uma entidade transcendente, ou seja, irredutível, e da qual não se escapa ao se fazer uso de drogas. Nesse caso, o risco é a legitimação inadvertida (pela via paradoxal da redução de danos concebida por essa ótica restrita) do discurso neopreventivista que legitima o proibicionismo.

\section{A Lógica Ampliada de Redução de Danos: adequando a perspectiva para uma prática libertária da assistência}

A ideia de redução de danos, quando relacionada ao uso de drogas, tem duas vertentes. Uma nascida na Grã-Bretanha, no início do século XX, motivada pelos problemas decorrentes do uso da heroína, que advém do estudo conhecido como Relatório Rolleston, de 1926. Esse estudo concluiu que os abusadores de opiáceos poderiam, com ajuda especializada, reduzir os danos provocados mesmo mantendo-se o uso da droga (O'Hare, 1994). A outra vertente nasceu na Holanda, na década de 1970. Nessa época, o governo holandês, diante do desafio de levar a cabo uma política de drogas cuja eficácia superasse o 'fracasso' das políticas dos países vizinhos - todos atrelados à repressão à oferta e demanda -, encomenda dois estudos científicos sobre o assunto: nascem, assim, o Relatório Baan, de 1972, e o Relatório Cohen, de 1975 (Cohen, 1994). 
Em ambos os trabalhos, e apesar de a Holanda ser signatária da Convenção Única de 1961 sobre Estupefacientes, ${ }^{10}$ sugeriu-se como política pública mais razoável a legalização da Cannabis. Contudo, é preciso ter em conta que, na época, parecia incontornável (assim como continua aparentando ser hoje) contrariar as convenções internacionais que impõem a proibição da aquisição de certas drogas. Então, em virtude da necessidade humanitária e lógica de se contornar a impossibilidade política e irracional da legalização, os holandeses criam como linha de fuga as estratégias de redução de danos. Assim, a primeira medida estratégica surge em 1978, quando o governo holandês cria, através de legislação específica, a distinção (meramente formal) entre drogas leves e drogas pesadas para, dessa maneira, e de forma mitigada, justificar ética e juridicamente (mesmo no contexto de vigência dos acordos internacionais) a permissão para a posse e a venda de Cannabis (que, dentre as drogas ilícitas, no caso holandês, era a de maior prevalência). Essa droga não passou a ser considerada 'liberada' (pelo menos não formalmente, caso contrário seria um ato de transgressão à Convenção de 1961), mas sua posse e uso passaram a ser apenas 'uma ofensa menor' por ser uma droga 'leve'. A venda de pequenas quantidades de Cannabis nos coffeeshops e nos clubes de jovens passou, por fim, a ser permitida em certas condições.

É importante perceber também que, diferente da abordagem britânica, o principal objetivo da política holandesa não seria, em primeiro lugar, reduzir os danos causados propriamente pelo uso de drogas, mas afastar os usuários habituais de Cannabis dos riscos oferecidos pelo mercado negro - incluindo o uso de produtos adulterados e o contato com a criminalidade derivada da proibição da própria Cannabis e de outras drogas. Ou seja, tanto a ideia original de redução de danos para os holandeses (o termo 'redução de danos', como conceito, é antes holandês do que britânico) quanto a invenção da hierarquia entre drogas leves e pesadas ${ }^{11}$ integram uma ampla e complexa

10 Segundo o Instituto Giovanni Falconi, a Convenção Única de Nova York, de 1961, introduziu a linha norte-americana da militarização, da proibição e da criminalização do porte e do consumo de drogas, preconizando-se penas privativas de liberdade severas nos preceitos secundários das leis penais nacionais. Assim, pensa-se que a ameaça contida na lei vai obrigar o consumidor, ainda que faça emprego lúdico-recreativo, a estabelecer, na orientação da sua conduta, uma inibidora relação de custo-benefício. Disponível em: <http://ibgf.org.br/index.php?data\%5Bid_ secao\%5D=4\&data\%5Bid_materia\%5D=123>. Acesso em: set. 2008.

11 Modo de pensar posteriormente 'roubado' por certa facção cientificista médico-moral. Na verdade, nenhuma droga pode ser, em si mesma, leve ou pesada. O único julgamento pertinente é o derivado do encontro entre substância e corpo, que pode ser considerado, caso a caso, adequado ou inadequado, conforme as regras da farmacodinâmica e da farmacocinética. 
estratégia que visava a reduzir os efeitos colaterais do proibicionismo. Apenas secundariamente, como tática acessória, inclui-se o ponto de vista médico de redução dos danos físicos e psicológicos ligados ao uso crônico e abusivo dos produtos químicos. Tal visão tornou-se paradigmática, em especial, por ter sido utilizada para auxiliar a frear a epidemia de Aids nas décadas de $1980-1990 .{ }^{12}$

O sucesso das medidas adotadas pela Holanda tornou o país um exemplo mundial de política 'razoável' no que diz respeito ao fenômeno das drogas - embora não se possa esquecer de que se trata de um sucesso relativo, dada a escalada crescente dos danos provocados pelo proibicionismo mundial. Além disso, tais medidas estão limitadas ao contexto holandês, que não é necessariamente exportável a outros países. ${ }^{13}$

Posteriormente à implantação da experiência holandesa, o quadro legal de integração regional que viabilizou a constituição da União Europeia, notadamente o Acordo de Schengen, ${ }^{14}$ se fez exigindo também a ratificação das convenções das Nações Unidas e, portanto, proibindo explicitamente os Estados signatários de desenvolverem políticas relativas à droga que prejudiquem as políticas mais restritivas adotadas pelos demais Estados.

Longe do Acordo de Schengen e da estratégia holandesa, e mais próxima da vertente britânica e dos tratados da ONU, a proposta de uma lógica ampliada de redução de danos feita pelo Ministério da Saúde brasileiro (Brasil/MS, 2003, 2004) parece mirar apenas os efeitos colaterais do uso das drogas na vida do organismo (cirrose, encefalite, pancreatite, polineurite) e nos aspectos da vida social (violência doméstica, acidentes de trânsito). Abandona, entretanto, na obscuridade que lhe é própria (por ser um ‘segredo' que lhe favorece a sobrevida), os malefícios do próprio proibicionismo, deixando de ser, na verdade,

12 Os holandeses também são os 'inventores' da redução de danos para o controle da epidemia da Aids.

13 Merece consideração o fato de que a decisão de 'separar' a Cannabis do mercado negro tem valido à Holanda perpétua censura de órgãos mundiais vinculados à guerra às drogas, em especial o Órgão Internacional de Controle de Estupefacientes (Oice). Ou seja, as críticas e os reiterados anúncios de fracasso das políticas holandesas não são provenientes de uma avaliação de resultados negativa, mas de uma campanha ideológica oriunda dos organismos internacionais alinhados ao proibicionismo (Abraham, Cohen \& Dirk, 2001). Tais críticas são constantemente desmentidas pelos vários governos holandeses pelos anos a fora - incluindo nota de desagravo aprovado por resolução do Parlamento Europeu em 2004. Disponível em: <www.senliscouncil. net/>. Acesso em: 13 abr. 2007. Não vemos como países menos dotados econômica e politicamente que a Holanda suportariam tamanha pressão externa.

14 As medidas relativas ao Acordo de Schengen preveem a abolição dos controles nas fronteiras internas dos seus estados-membros. 
uma lógica ampliada, para ser uma restrição que, em última análise, favorece o acordo formal da guerra às drogas com a 'redução de danos'.

Para uma crítica que se quer radical e que, por isso, clama ser um exercício capaz de questionar até as próprias crenças e desejos, é necessário considerar que, como sugerida até o momento, a redução de danos pode, em sua polissemia, resultar em um aggiornamento dos processos antigos, medicalizados e moralistas de atenção à saúde do farmacodependente, ainda que sob uma roupagem progressista. Mesmo que se concorde com a necessidade, em termos de uma política pública de saúde, da construção de uma lógica ampliada efetiva (uma radicalização) da redução de danos, é preciso discutir claramente de que redução de danos se trata e do que na verdade necessitamos segundo nossa realidade. Deveríamos antes nos perguntar, então, o que realmente seria mais interessante para nós: adequar a matriz de redução de danos anglo-saxã ${ }^{15}$ centrada na ideia de que o uso de drogas é um problema de saúde, ou utilizar, de forma radicalizada, o modelo holandês contra os efeitos deletérios do proibicionismo. Ou ainda, se deveríamos inventar um amálgama entre ambas as perspectivas, inglesa e holandesa.

De qualquer forma, sem a chave que abre a caixa de Pandora para deixar escapar o seu segredo, sem a formulação correta dos problemas e da elaboração de suas soluções, não há como excluir a possibilidade de que a implantação da política pública para as drogas torne-se apenas mero aggiornamento tolerante e piedoso do proibicionismo reinante. Este sempre insistiu, para se autolegitimar, na ideia de que as drogas são um problema de saúde pública, e, portanto, antes de mais nada, também de segurança pública. Não há resistência alguma às consequências do proibicionismo ao se reivindicar o problema-drogas para a área da saúde, mantendo-se a ideia de saúde para o dependente químico atrelada apenas à ausência ou ao controle de danos médico-psicológicos (retomada da ideia de saúde como ausência de doença, o que não necessariamente impede que se pense as drogas numa perspectiva de qualidade de vida, mas certamente limita as possibilidades das ações de promoção da saúde como qualidade de vida).

A questão é primeiro desmistificar as drogas como entes maléficos e essencialmente produtores de danos para, caso a caso, planejar qualquer controle preventivo, seja em termos de saúde, seja em termos de segurança.

15 Os canadenses, por exemplo, fazem questão de afirmar que a sua política enfatiza os danos, sendo sua primeira prioridade diminuir as consequências negativas do uso de drogas para o próprio indivíduo e para os outros (CCSA, 1994). 


\section{Conclusão}

No Brasil, o maior consumo concentra-se nas drogas legalizadas (como o álcool, o tabaco e os calmantes), em alguns produtos de uso industrial (como a cola de sapateiro) e outros de fabricação caseira. São estes que causam os maiores danos por abuso ou uso indevido.

O último levantamento sobre o uso de drogas entre adolescentes brasileiros, apresentado em 2005, apenas confirma os dados levantados em 2001 no I Levantamento Domiciliar Sobre Uso de Drogas no Brasil (Carlini et al., 2002), ambos publicados pelo Centro Brasileiro de Informações sobre Drogas Psicotrópicas (Cebrid). A análise dos números reitera que a maconha é a única das drogas ilícitas, entre as cinco mais frequentemente consumidas no país, com uma prevalência substancialmente mais baixa do que aquela referente às drogas legalizadas (em especial, álcool, tabaco e solventes). Além disso, o estudo demonstra que o uso de drogas no país, apesar de merecer atenção pelas tendências de incremento em anos recentes, não tem a magnitude que se imagina. A maioria da população nunca usou drogas ilícitas, e dentre aqueles que as utilizaram a maior parte o fez apenas a título de experimentação.

O estudo comprova, no entanto, a facilidade com que a população geral tem acesso às drogas, o que é um indicador da falência dos meios utilizados nos últimos anos para a prevenção e o combate à oferta no país. O problema é que, na evidência desse fracasso, o que se propõe frequentemente não é o abandono do ponto de vista 'demonizador', que vem caracterizando as medidas preventivas e o combate ao uso de drogas, mas o seu recrudescimento, ou pior, a cessação de toda iniciativa de problematização da lógica do proibicionismo, tornando tal ponto de vista mais potente mediante a sutil incorporação da redução de danos ao arcabouço estratégico do combate às drogas. No Brasil, esse processo, que mantém e amplia a hegemonia do proibicionismo, se expressa no discurso jurídico-político consagrado pelo realinhamento das políticas públicas para as drogas, consubstanciado pela nova Lei de Entorpecentes de 2006, que, ao mesmo tempo, intensifica as medidas de interdição à demanda e oferta de drogas e ameniza as ações contra os usuários. Assim, deixa-se de analisar causas e efeitos que conduzam ações adequadas para, ao contrário, reiterar as soluções baseadas em um tipo de senso comum que produz cada vez mais iniquidade. Senso comum que insiste em tingir com alarmismo apocalíptico as drogas, investindo-as de um caráter metafísico maléfi- 
co que estão longe de possuir. Deixa-se de se perceber, dessa maneira, que muitos dos problemas com as drogas derivam da proeminência avaliativa dos princípios do Direito sobre os fisiológicos e bioquímicos, ou seja, que a magnitude e dramaticidade das consequências sociais resultantes do uso de drogas não são explicáveis apenas pelos efeitos possíveis das drogas sobre a fisiologia humana, nem por seus princípios bioquímicos, mas principalmente pela demonização das drogas e pela cultura do medo subjacentes à repressão militarizada induzida em cada país pelos tratados internacionais antidrogas. Como diz Escohotado (1998), a natureza farmacológica das drogas em nossas sociedades é apenas uma função do regime jurídico e, dessa maneira, não pode ocultar a estratégia de poder que está em jogo.

\section{Referências}

ABRAHAM, M. D.; COHEN, P. D. A. \& DIRK, J. B. Letter to the editors. The British Journal of Psychiatry, 179: 175-177, 2001.

BRASIL. Lei de Entorpecentes n. 6.368, 21 out. 1976. Disponível em: <www.planalto. gov.br/ccivil_03/leis/L6368.htm>. Acesso em: 29 jul. 2009.

BRASIL. Lei de Crimes Hediondos 8.072, 25 jul. 1990. Disponível em: <www.planalto. gov.br/ccivil_03/LEIS/L8072.htm>. Acesso em: 29 jul. 2009.

BRASIL. Ministério da Saúde. A Política do Ministério da Saúde para a Atenção Integral a Usuários de Álcool e Outras Drogas. Brasília: Ministério da Saúde, 2003.

BRASIL. Ministério da Saúde. A Política do Ministério da Saúde para a Atenção Integral a Usuários de Álcool e Outras Drogas. 2. ed. revista e ampliada. Brasília: Ministério da Saúde, 2004.

BRASIL. Lei de Entorpecentes n. 11.343, 18 ago. 2006. Disponível em: <www.planalto. gov.br/ccivil_03/_Ato2004-2006/2006/Lei/L11343.htm>. Acesso em: 29 jul. 2009.

BUCHER, R. \& OLIVEIRA, S. R. M. O discurso do "combate às drogas" e suas ideologias. Revista de Saúde Pública, 28(2): 137-145, 1994.

CANADIAN CENTRE ON SUBSTANCE ABUSE (CCSA). National Working Group on Policy. Ottawa: CCSA, 1994.

CARLINI, E. A. et al. I Levantamento Domiciliar sobre o Uso de Drogas Psicotrópicas no Brasil: estudo envolvendo as 107 maiores cidades do país. São Paulo: Centro Brasileiro de Informações sobre Drogas Psicotrópicas, Universidade Federal de São Paulo, 2002. 
COHEN, P. The case of the two dutch drug policy commissions: an exercise in harm reduction 1968-1976. In: 5TH INTERNATIONAL CONFERENCE ON THE REDUCTION OF DRUG RELATED HARM, 7-11, mar. 1994, Toronto. Anais... Toronto: Addiction Research Foundation, 1994. (Revised in 1996)

COIMBRA, C. Produzindo o mito da "guerra civil": naturalizando a violência. In: BAPTITA, M.; CRUZ, M. S. \& MATIAS, R. (Orgs.). Drogas e Pós-Modernidade 2: faces de um tema proscrito. Rio de Janeiro: Editora da Uerj, 2003.

DELEUZE, G. Duas questões. SaúdeLoucura, 3. São Paulo: Hucitec, 1991.

DELEUZE, G. Diferença e Repetição. São Paulo: Edições Graal, 2006.

DORES, A. P. A. Proibicionismo - contribuições para um debate sobre as finalidades sociais da justiça. Sociedades Contemporâneas - Reflexividade e Acção, I: 64-75, 2004.

ESCOHOTADO, A. Historia General de las Drogas. Madrid: Editorial Espasa, 1998.

ESCRITÓRIO DAS NAÇÕES UNIDAS CONTRA DROGAS E CRIME (UNODC). Perfil de País: Brasil. Brasília: UNODC, 2003.

ESTEBAN, J. El Direcho a la Ebriedad: manifesto libertário contra la prohibición. Madrid: Ediciones Amargord, 2007.

FOUCAULT, M. História da Sexualidade I: a vontade de saber. Rio de Janeiro: Edições Graal, 1985.

INSTITUTO BRASILEIRO DE GEOGRAFIA E ESTATÍSTICA (IBGE). Síntese dos Indicadores Sociais. Brasília: 2002. Disponível em: <www2.ibge.gov.br/pub/Indicadores_Sociais/ Sintese_de_Indicadores_Sociais_2003>. Acesso em:22 jul. 2007.

KOUTOUSIS, M. \& PEREZ, P. Atlas Mondial des Drogues. Paris: PUF, 1996.

MISSE, M. O movimento: a constituição e reprodução das redes do mercado informal ilegal de drogas a varejo no Rio de Janeiro e seus efeitos de violência. In: BAPTITA, M.; CRUZ, M. S. \& MATIAS, R. (Orgs.). Drogas e Pós-Modernidade 2: faces de um tema proscrito. Rio de Janeiro: Editora da Uerj, 2003.

OBSERVATÓRIO EUROPEU DA DROGAS E DA TOXICODEPENDÊNCIA (OEDT). Relatório Anual 2003: a evolução do fenômeno da droga na União Europeia e na Noruega. Luxemburgo: Serviço das Publicações Oficiais das Comunidades Europeias, 2003.

O'HARE, P. Redução de danos: alguns princípios e a ação prática. In: MESQUITA, F. \& BASTOS, F. I. (Orgs.). Drogas e Aids: estratégias de redução de danos. São Paulo: Hucitec, 1994.

QUAGLIA, G. O tráfico de drogas como motor da violência. In: ALARCON, S. O Diagrama das Drogas: cartografia das drogas como dispositivo de poder na sociedade 
brasileira contemporânea, 2008a. Tese de Doutorado. Rio de Janeiro: Escola Nacional de Saúde Pública Sergio Arouca, Fundação Oswaldo Cruz. (Mimeo.)

QUAGLIA, G. Os jovens e as drogas: a importância da prevenção e do tratamento. In: ALARCON, S. O Diagrama das Drogas: cartografia das drogas como dispositivo de poder na sociedade brasileira contemporânea, 2008b. Tese de Doutorado. Rio de Janeiro: Escola Nacional de Saúde Pública Sergio Arouca, Fundação Oswaldo Cruz. (Mimeo.) 


\title{
3
}

\section{O Campo de Atenção ao Dependente Químico}

\author{
Sergio Alarcon \\ Pilar Rodriguez Belmonte \\ Marco Aurélio Soares Jorge
}

O 'campo de atenção ao dependente químico' é a expressão de lutas e relações de atores sociais que procuram, cada qual a seu modo, impor sua perspectiva. Entende-se por atores sociais aqueles capazes de gerar estratégias ou propostas para a resolução de questões explícitas de reprodução social (Bourdieu, 1990). Por isso, para se tentar minimamente entender a realidade da atenção pública ao dependente químico, temos que, em primeiro lugar, definir quais são os atores que delineiam o campo para, em segundo lugar, definir os trunfos de que cada um lança mão para dominar o jogo em disputa. $\mathrm{Na}$ verdade, estando o jogo em aberto, está também em aberto a legitimidade do próprio campo. Citando Pierre Bourdieu, o campo de atenção ao dependente químico é "o lugar de uma luta pela definição, isto é, a delimitação das competências, competência no sentido jurídico do termo, vale dizer, como delimitação de uma alçada" (Bourdieu, 1990: 120).

A seguir, apresentamos um mosaico genealógico, construído a partir da perspectiva da saúde pública e de alguns elementos diretamente associados ao discurso jurídico-político, como substrato para uma análise crítica sobre a emergência desse campo de realidade e lutas. Campo este que se manteve unívoco desde a lei n. 6.368/76 (Brasil, 1976) e se desarticulou momentaneamente, durante o espaço de tempo entre a entrada em vigor da lei da reforma psiquiátrica (em 2001) até a promulgação, em 2006, da nova lei de entorpecentes (Brasil, 2006). 


\section{A Hegemonia dos Modelos Unicausais no Tratamento da Dependência Química}

No Brasil, antes da implantação do Sistema Único de Saúde (SUS), pelo termo saúde entendia-se, basicamente, o bem-estar físico acompanhado por ausência de doença. Esta era uma ideia de saúde já antiga, tributária da hegemonia do modelo biomédico, baseado no mecanicismo que se desenvolveu a partir das revoluções científica e industrial - entre os séculos XVI e XVIII - e que foi a condição de possibilidade para o surgimento da medicina científica, em fins do século XVIII (Foucault, 1988a). Esse modelo considerava a doença como um transtorno eventual ou permanente de uma peça ou da relação entre as peças da engrenagem do corpo humano. Curar a doença equivalia, nessa perspectiva, à reparação da engrenagem.

Ainda que o mecanicismo filosófico-científico tenha se tornado uma condição para a medicina moderna, sua disseminação hegemônica deu-se apenas graças a uma série de eventos não científicos, que surgiram por motivação política e/ou econômica, e cujo resultado na organização da educação em saúde e nos equipamentos sanitários comumente é denominado 'poder-médico'. Sobre alguns componentes historicamente marcados do poder-médico, podemos citar, por exemplo, a institucionalização da profissão médica pelo Estado moderno, o controle da higiene e da salubridade pública e o controle da população pobre. Por institucionalização da medicina deve-se entender o controle pelo Estado dos programas de ensino e atribuição de diplomas, subordinação da prática médica a um poder administrativo superior, adoção do médico como 'administrador' da saúde etc. Por salubridade pública, entenda-se o estado das coisas, do meio e de seus elementos constitutivos, que permitem a melhor saúde possivel para um determinado grupo ou população - é correlativamente a ela que, por exemplo, surge a noção de higiene pública, técnica de controle e de modificação dos elementos materiais do meio que podem favorecer ou, ao contrário, prejudicar a saúde. A higiene pública - que surge no século XIX como noção essencial da medicina social francesa - é a responsável pelo controle político-científico desse meio (Foucault, 1988a). Por fim, o controle da população pobre deve ser entendido como toda a sorte de intervenções - que incluem a verificação de vacinas, o registro de doenças e as ações em locais considerados insalubres - a partir das quais uma espécie de cordão sanitário autoritário é estendido no interior das cidades, promovendo a separação entre ricos e pobres: 
"os pobres encontrando a possibilidade de se tratarem gratuitamente ou sem grande despesa e os ricos garantindo não serem vítimas de fenômenos epidêmicos originários da classe pobre" (Foucault, 1988b: 56).

Pode-se dizer que esse processo, nas sociedades ocidentais, foi desigual no tempo e no espaço, tornando, da mesma forma, desigual nos Estados a aplicação do modelo mecanicista cartesiano difundido pela ciência e por parte constituinte do poder-médico. Aqui, afirma-se que esse modelo foi universalizado no meio acadêmico ocidental apenas após a reforma flexneriana, ocorrida no ensino médico norte-americano no início do século passado e difundida mundialmente após a Segunda Guerra Mundial.

A reforma flexneriana foi implantada por volta de 1910, com base no relatório elaborado pelo educador Abraham Flexner. Sobre isso, Nassif (2006) afirma que

no início do século passado, mais precisamente em 1906, os Estados Unidos e o Canadá passavam por uma situação constrangedora no ensino médico. Tinham 160 faculdades de medicina quase todas mal equipadas, sem currículo regulamentado, corpo docente fraco e carente. A maioria comercializava o ensino médico, preocupada apenas com o lucro. Dezenas de milhares de médicos eram por elas diplomados anualmente, número bem acima do necessário, aliado a um impressionante percentual de profissionais despreparados. Durante quatro anos, de 1906 a 1910, Flexner visitou cada uma das 160 escolas - todas sem exceção - e elaborou um extenso e minucioso relatório, publicado no Boletim n. 4 da Fundação Carnegie em 1910.

Seus parâmetros, transformados em política pública, induziram à fusão e ao fechamento de 94 escolas de medicina. A essência do modelo flexneriano está concentrada nos aspectos curativos - face à valorização que confere ao diagnóstico e à terapêutica -, corroborados pelo conhecimento dos processos anatômicos e fisiopatológicos que, aliados à microbiologia pasteuriana, revolucionaram as práticas médicas - constituindo uma ruptura essencial com a perspectiva da medicina medieval - e caracterizaram o nascimento da anatomoclínica (Foucault, 1985). Por conseguinte, a hegemonia daquilo que ficou conhecido como poder-médico solidificou-se apenas a partir da internacionalização da reforma de Flexner, contaminando a totalidade das outras disciplinas vinculadas direta ou indiretamente à institucionalização da medicina pelo Estado moderno. Ou seja, o poder-médico não deve ser entendido, em primeiro lu- 
gar, como o poder de um indivíduo ou corporação, mas principalmente como a hegemonia do modelo biomédico, institucionalizado pelo Estado, que organizou a racionalidade do ensino, da pesquisa e da assistência à saúde em todos os níveis e em todas as profissões posteriormente capazes de conexão direta com a medicina (serviço social, psicologia, odontologia, fisioterapia, enfermagem etc.).

Acredita-se que a hegemonia biomédica das práticas da saúde tenha, por um lado, trazido grandes benefícios para a resolubilidade da assistência, mas tenha, por outro, também desenvolvido a tendência de compreensão reducionista do processo saúde/doença, visto exclusivamente em uma dimensão unicausal (em geral, biológica). Como seria de se esperar, a omissão que o modelo biomédico faz dos processos de individuação e subjetivação (mesmo que se possa dizer que o poder-médico seja um dos componentes do processo de individuação contemporâneo) é consistente com as definições de saúde e doença a ele conotadas.

A longa duração do paradigma unicausal e sua definição negativa de saúde (como ausência de doença) facilitaram a disseminação quase universal da ideia de que apenas a abstinência total significaria um horizonte possível para o tratamento da dependência química. A crença na adequação entre tratamento e abstinência, ao mesmo tempo que é resultante da ideia puritana que torna as drogas a encarnação do mal, está em sintonia com o discurso jurídico-político proibicionista de 'erradicação' das drogas da sociedade por estas se constituírem em um risco à saúde e à segurança do indivíduo e da população.

Essa comunhão saúde/segurança fez com que as estratégias de intervenção sanitária aos dependentes químicos concentrassem seus objetivos unicamente na aquisição do estado de abstinência total, sem promover o desenvolvimento de estratégias intermediárias nas quais a abstinência fosse menos que um marco moral, menos que um dever, considerando-a, em geral, desejável. Assim, nenhuma contradição se fez entre as condutas clássicas médico-psicológicas de intervenção (que invariavelmente interpretavam a dependência química como falha genética, falta inconsciente ou fraqueza moral) e as intervenções religiosas baseadas nos modelos norte-americanos de lastro puritano. E muito menos houve qualquer descontinuidade aparente entre a perspectiva jurídico-política, baseada na repressão e combate às drogas, e os modelos assistenciais disponíveis na sociedade como um todo e no setor público em particular.

Ainda hoje, a memória dessa época encontra forte eco no Brasil, de tal maneira que alguns estados da federação institucionalizaram essas 'soluções' tradicionais - notadamente o governo do estado do Rio de Janeiro, que desde 2000 sustenta um projeto de intervenção sanitária fora do setor saúde (na pasta da 
assistência social, com gerência de organizações não governamentais (ONGs) ligadas a religiões protestantes), ${ }^{1}$ e o governo do estado do Rio Grande do Sul, que adotou como ‘solução' a chamada justiça terapêutica. ${ }^{2}$

\section{Os Princípios das Ações Públicas de Saúde após a Reforma Sanitária}

Ainda que, como nos coloca Foucault (1988a), a medicina científica tenha nascido como medicina social, o modelo biomédico pós-reforma flexneriana enfatizou a predominância da assistência médica hospitalocêntrica, curativa e individual e não a predominância da assistência e do entendimento negativo da saúde, interpretada como um estado físico e mental "ausente de doença" (OMS, 1978). No Brasil, é do sanitarista Sergio Arouca uma das principais críticas a esse modelo. Arouca elencou aspectos em que o modelo flexneriano (ou curativista) mostrou-se ineficiente, dentre os quais pode-se destacar três: o curativismo, que se centralizou na intervenção terapêutica, descuidando-se da prevenção da ocorrência e levou ao encarecimento da

Trata-se do projeto "Clínicas Populares". Esse projeto surge de uma política de governo advinda da vitória, no estado do Rio de Janeiro, nas eleições de 1998, da coligação de esquerda PDT/PT, que se inseria não em uma política de saúde, mas em uma particularidade da política de segurança pública relacionada ao controle do tráfico de drogas ilícitas e suas consequências. Inicialmente sob a responsabilidade da Secretaria de Estado de Justiça, o projeto sofreu mudanças, sendo realocado para a Secretaria de Estado de Ação Social. Os pontos fracos do projeto incidiam principalmente, a nosso ver, não em um suposto ecletismo metodológico nas condutas terapêuticas, nem em uma tendência a preferir o modelo Minnesota à clínica da toxicomania ou qualquer outra vertente científica ou protocientífica, mas nos seguintes tópicos: 1 - desvinculação com o setor saúde e abertura de consequente brecha para o não cumprimento dos princípios do SUS; 2 - escolha de comunidades terapêuticas (CT), todas de cunho religioso, para gerir a contratação e administração dos recursos humanos; 3 - riscos provenientes dessa terceirização, com a possibilidade de contratação de pessoal não qualificado; 4 - risco de invasão, na área pública, de formas de tratamento particularistas - resumidas basicamente pelo assistencialismo/messianismo religioso, na medida em que cada CT formalmente não estava impedida de construir o projeto terapêutico baseando-se em seus próprios interesses privados (Alarcon, 2008).

2 A justiça terapêutica visa à aplicação de uma das penas previstas ao usuário de droga proibida, através da sua inserção em tratamento a ser ministrado por uma equipe colegiada integrada por médicos, psicólogos e assistentes sociais, entre outros, que se tornam 'auxiliares' dos profissionais do direito na condução e aplicação do procedimento. Trata-se de um tipo de abordagem de inspiração norte-americana (Drug Courts), legitimado por um ponto de vista que define, de forma sumária, o usuário como o principal provedor e motivo de existência do narcotráfico. Por isso, supõe ser possível conter com maior eficácia a oferta (o tráfico), combatendo concomitantemente a 'demanda' (o usuário). 
atenção médica e à redução do seu rendimento; a indução a uma educação médica voltada para as especialidades - esse aspecto fez com que o homem fosse cada vez mais reduzido a órgãos e estruturas, perdendo-se a noção de sua totalidade, fato que levou ao desaparecimento do humanismo médico; a medicina curativa que, realizada dentro de um contexto de interesses puramente individualistas, desvinculou-se dos reais problemas de saúde da população (Arouca apud Czeresnia \& Freitas, 2003).

Sem querer entrar no mérito sobre a pertinência dessas críticas - especialmente por não abalarem o chamado poder-médico, mesmo propondo certa desmedicalização das ações de saúde -, o fato é que tanto a reforma sanitária quanto a reforma psiquiátrica brasileiras se apoiaram nas diferentes críticas aos efeitos considerados excludentes da organização flexneriana da medicina, sendo sua principal consequência teórica provavelmente a adoção de outra corrente de pensamento que propunha a inflexão do que antes caracterizava a ideia de saúde como ausência de doença. Essa modificação na preferência teórica trouxe para a política de saúde no país, de certa maneira, a relativização da importância dos atos curativos - em geral vinculados às ações da assistência médica segundo o modelo unicausal das doenças - e a valorização das estratégias e dos aparelhos promotores de saúde, tornados interdisciplinares e intersetoriais, tributários de uma complexidade distinta daquela predominantemente 'especialística'. ${ }^{3}$

Nesse contexto, desenvolveu-se no Brasil, por influência do estabelecido na Conferência de Saúde de Alma-Ata (OMS, 1978) e sob o notável viés do modelo sanitário canadense (Czeresnia \& Freitas, 2003), a ideia de saúde como qualidade de vida. Essa definição de saúde implicou a ampliação da perspectiva sobre o processo saúde-doença para além dos enfoques unicausais e a consequente reorientação das políticas públicas do setor em suas estratégias de incorporação de questões sociais, econômicas e ambientais. A nova visão do processo saúde-doença forçou o reconhecimento de que os equipamentos da rede pública - caracterizados por estruturas medicalizadas (curativas), que respondiam primordialmente às demandas espontâneas da população, além de obedecerem a uma organização setorialmente isolada - não conseguiam enfrentar os múltiplos determinantes das condições de saúde. Ênfase maior passou a ser conferida às ações locais, mais próximas da realidade efetivamente

3 É importante fazer-se a ressalva de que nem a reforma sanitária nem a psiquiátrica, em nenhum momento, preconizaram o fim da medicina científica ou da medicina mental, mas o fim da hegemonia de seus pontos de vista sobre a organização dos serviços públicos de assistência. 
vivenciada pelos indivíduos. Ao mesmo tempo, percebeu-se a necessidade de se organizar serviços mais dinâmicos e porosos às múltiplas demandas comunitárias, que não são facilmente respondidas apenas com ações curativas ou preventivas. Por isso, tornou-se questão primordial definir, nos diferentes ambientes sociais e culturais, como as pessoas entendem as causas do adoecimento e como se comportam em relação aos tratamentos possíveis e disponíveis em seu meio. E, mais importante, criou-se a expectativa de que essa comunidade, atuando de forma corresponsável, fosse capaz de interferir a ponto de reinventar os dispositivos para esses tratamentos e cuidados, no horizonte da promoção social da qualidade de vida.

Ao definir a saúde tomando-se por base seus princípios e doutrinas, ${ }^{4}$ o SUS colocou a promoção social da qualidade de vida como a perspectiva estruturante dos seus dispositivos de ação (conforme o conceito de integralidade e o conceito de saúde como qualidade de vida). Essa inflexão em relação ao modelo anterior, bipartido entre o 'preventivismo' e o 'curativismo' fez emergir ações de cunho político-social, capazes de provocar efeitos diferenciais tanto na prevenção quanto na estrita 'recuperação' ou 'cura'. Isso significa que, em termos de parâmetros para o início ou o fim das ações sanitárias, não basta estar livre de doença para se ter saúde; saúde esta que deixa de ser apenas uma questão de assistência puramente médica. ${ }^{5}$

A ideia de saúde ampliada (como qualidade de vida) por si mesma não significou o fim daquilo que anteriormente caracterizamos como poder-médico. Pelo contrário, há o risco de que uma medicalização muito mais intensa e microfísica se processe, na medida em que, em virtude da associação entre duas ideias polissêmicas como saúde e qualidade de vida, os mecanismos de controle sanitário tendam a se tornar ubíquos (tudo é saúde, já que tudo almeja

\footnotetext{
4 O SUS tem por princípios a universalidade, a equidade e a integralidade, tendo ainda como diretrizes de organização a descentralização e a participação da sociedade.

5 Resumindo, a reestruturação do setor saúde privilegia: o atendimento primário, no quadro dos sistemas locais de saúde, com o objetivo de facilitar a promoção de modelos alternativos, centrados na comunidade e dentro de suas redes sociais (estratégia saúde da família e reforma psiquiátrica) e a revisão crítica do papel hegemônico e centralizador do hospital na prestação de serviços. Além disso, os recursos, cuidados e tratamentos devem salvaguardar a dignidade pessoal e os direitos da cidadania, estar baseados em critérios racionais e tecnicamente adequados e propiciar a permanência do enfermo em seu meio comunitário. As legislações dos estados e municípios devem ajustar-se para assegurar o respeito aos direitos humanos e civis dos doentes e promover a organização de serviços comunitários de saúde que garantam seu cumprimento. A capacitação dos recursos humanos em saúde deve fazer-se apontando para um modelo cujo eixo passa pelo serviço de saúde comunitário, tomando como exceção a internação nos hospitais gerais, de acordo com os princípios que regem e fundamentam essa reestruturação.
} 
melhorar a qualidade de vida), agindo no tempo-espaço de cada indivíduo e da população, de uma maneira geral, de forma perene almejando todas as suas valências causais possíveis.

Assim, ao promover estratégias de intervenção dessa maneira abrangente, a promoção social da qualidade de vida pode se transformar em uma máquina (não necessariamente intencional) voltada para o melhor governo da vida, no sentido biopolítico do termo, ${ }^{6}$ o que inclui as condições econômicas, sociais e afetivas de estar no mundo. A promoção social da qualidade de vida não significa, por si só, uma barreira à hegemonia do poder-médico implícito no modelo flexneriano. Se mal-entendida pode abrir a possibilidade de aggiornamento $^{7}$ e ampliação da medicalização da sociedade ao mesmo tempo que amplia a 'função-médico'.

Se o médico era antes o responsável pela saúde do corpo, capaz apenas de agir sobre determinadas coordenadas que, em última instância (mesmo aquelas que tangenciam a sociedade e o ambiente), são determinadas pelos limites biológicos, passa, com a ampliação da ideia de saúde, a ser também corresponsável pela 'saúde social', agindo indistintamente sobre todos os aspectos que pretensamente possam influir na qualidade de vida do indivíduo e da população. Torna-se difícil agora distinguir não apenas aquele personagem egresso das faculdades de medicina e aqueles egressos das outras profissões obedientes ao poder-médico, mas também distingui-los do conjunto de profissionais conectados intersetorialmente pelo valor saúde, já que a todos é atribuída um quantum da função-médico. Em outras palavras, a função-médico

\footnotetext{
${ }_{6}$ Para Foucault (1985), a medicalização da sociedade se dá quando o valor saúde passa a dominar não apenas o pequeno mundo do hospital, mas toda a sociedade. Foucault chama essa perspectiva avaliadora que medicaliza nossos corpos e almas de biopoder. Com efeito, até o século XVIII, as forças do poder político eram as da morte, ligadas ao exercício da soberania. O poder político só intervinha no campo social para matar. O biopoder, ao contrário, é o poder de produzir vida - a saúde torna-se por isso o valor dominante da nossa sociedade. Foucault então distingue duas fases do biopoder: uma, ligada ao corpo individual, que ele chama de anatomopolítica, e outra, mais recente, que engloba a anterior, ligada à invenção do conceito de população: a biopolítica da espécie. A biopolítica trata de questões como: relação natalidade /mortalidade; normalização das relações pais/filhos (desaparece a família patriarcal, surge a família conjugal e o interesse em colocar a criança mais próxima da mãe; consequente separação do corpo das crianças e o dos serviçais - fim da ama de leite); sexualidade (passagem do dispositivo da aliança, ligada à reprodução, ao dispositivo da sexualidade, ligada ao prazer) etc. 7 Aggiornamento é uma palavra italiana que, ao pé da letra, significa 'atualização'. Foi utilizada para sintetizar o Concílio Vaticano II e, por isso, virou moda nos anos 60. Robert Castel a utiliza para enfatizar a possibilidade de fracasso na reforma psiquiátrica quando esta se reduz a um processo de recuperação do velho - de uma reforma no sentido lato que acaba por legitimar, ao invés de desconstruir, as velhas formas criticadas da psiquiatria (Castel, 1976).
} 
propriamente dita amplia sua potência simbólica, torna-se 'médico-social', e a sombra do poder-médico atinge outros setores além do setor saúde.

Nesse caso, a medicalização da sociedade independe do resultado das lutas corporativas - travestidas como se fossem lutas 'éticas' - entre as entidades representativas dos médicos e aquelas que representam as demais profissões que, de fato, surgiram à sombra do poder-médico, e que, queira-se ou não, continuaram sua evolução técnico-científica vinculada a esse mesmo modelo. Isso não significa que os próprios médicos, assim como outros profissionais da saúde, não produzam críticas ao poder-médico, mas significa ser ainda o poder-médico hegemônico na determinação do sentido do valor saúde, que se reforça e pode se alastrar caso a ideia de saúde como qualidade de vida não seja devidamente problematizada. Foucault entende o poder-médico como um caso do poder disciplinar, e é nesse sentido também que ele acaba avaliando as práticas da clínica 'psi' (psicológicas, psicanalíticas ou médicas) como práticas biopolíticas (Foucault, 1985).

Mediante essa hipótese, a promoção da saúde corre o risco de ser meramente a expansão da medicalização da sociedade, pontuando as determinações da biopolítica como critério para a avaliação da qualidade de vida, mantendo todos os discursos cada vez mais aderidos ao poder-médico, sem possibilidade de escape.

\section{A Reforma Psiquiátrica}

A reforma psiquiátrica, apesar de sua especificidade, de modo geral está de acordo - como não poderia deixar de ser - com os referenciais teóricos da reforma sanitária. Propõe 'desconstruir' o modelo assistencial anterior, baseado no entendimento biomédico dos transtornos mentais, e construir um novo estatuto social para o portador de 'sofrimento psíquico', incluindo-o como ator de sua própria inserção na cultura cívica da sociedade. A reforma não pretende acabar com o tratamento clínico e muito menos com a psiquiatria, mas sim eliminar os efeitos deletérios da prática de institucionalização do sujeito. Para tanto, elabora a substituição das estruturas manicomiais pela implantação progressiva de uma rede de serviços territoriais (comunitários) de atenção psicossocial. Nesse modelo de cuidado, há a pretensão de oferecer aos usuários dos serviços equipes organizadas de forma interdisciplinar para o acompanhamento individual. Há também o interesse de tornar os usuários agentes 
do próprio tratamento, com o direito de se organizarem em associações que, em tese, poderiam se conveniar a diversos serviços comunitários, favorecendo assim a inserção social de seus membros.

Com a reforma psiquiátrica, o tratamento das chamadas 'doenças mentais' não envolve simplesmente um processo de diagnóstico e cura, como pretendia a psiquiatria clássica, ansiosa por ser tributária do modelo biomédico. O sistema de atenção previsto pela reforma supõe 'cuidar' do portador de transtornos mentais sem reduzir a complexidade do sujeito humano aos sinais e sintomas de uma pretensa 'doença' sem etiologia. Portanto, tem o objetivo de atender às pessoas que necessitam de apoio tanto em suas relações mínimas para o cuidado de si quanto em suas relações com o meio social, econômico e político.

A lei federal n. 10.216 (Brasil, 2004), sancionada em 6 de abril de 2001, constitui a política de saúde mental oficial para o Ministério da Saúde, bem como para todas as unidades federativas. Sobre ela e a correspondência mantida com a reforma sanitária, pode-se dizer que: seus pressupostos são coerentes com a ideia de que a saúde não se reduz à ausência de doença (analogamente, a reforma psiquiátrica utiliza a epoché basagliana. Epoché - suspender, colocar entre parênteses - é um termo oriundo da filosofia, que significa em seu sentido grego original a posição de não aceitar nem negar uma determinada proposição ou juízo. A suspensão do juízo sobre a verdade ou falsidade da doença mental - colocar a doença mental entre parênteses -, empregada por Franco Basaglia, tem o objetivo de ampliar o horizonte ético-político do cuidado para além dos procedimentos médico-psicológicos, colocando a doença entre parênteses, com o objetivo de fazer emergir, em meio ao reducionismo dos sinais e sintomas nosológicos, a 'territorialidade' que caracteriza o sujeito como singularidade; a doença (mental) entre parênteses conduz à necessidade de se construir formas mais complexas de lidar com o sofrimento psíquico (atenção psicossocial, com base territorial, substitutivo ao modelo manicomial); essas ações complexas se traduzem, resumidamente, nos vários dispositivos que compõem um serviço territorial de saúde mental - os centros de atenção psicossocial (Caps), os clubes de convivência e de lazer assistidos, as cooperativas de trabalho protegido, as oficinas de geração de renda, as residências terapêuticas etc.; há analogia e coerência entre os pressupostos da reforma psiquiátrica e a ideia de saúde como qualidade de vida adotada pelo SUS.

O fenômeno da dependência química - identificada pelo modelo biomédico como transtorno mental - apenas recentemente foi submetido às transformações críticas da psiquiatria moderna, ou seja, atravessado por uma série de 
discursos que tendem a colocar em questão o papel da medicina mental (e/ou de qualquer outro proveniente das profissões conexas) como único produtor da verdade da 'doença' (Foucault, 1988a). Uma das críticas 'antipsiquiátricas' centra-se na iatrogenia derivada do hospitalocentrismo, identificando, tanto nas estruturas diretamente ligadas à psiquiatria quanto naquelas instituições regidas pela mesma racionalidade de fundo (ainda que aparentemente 'desmedicalizadas'), limitações inerentes ao conceito de saúde/doença unicausal (seja biológico, moral, psicológico ou do inconsciente) -, o que favoreceria determinadas relações de poder em nome das exigências da ordem social e das necessidades terapêuticas que pediam o isolamento dos doentes.

É nesse sentido que os espaços fechados de tratamento ao dependente químico, como as instituições hospitalares e as comunidades terapêuticas, e suas demandas por 'cura', passam a ser consideradas como espaços nos quais aparecem as relações de dominação daquele que exerce seu poder 'terapêutico' e de 'adestramento' sobre um cidadão subitamente tornado sem direitos, abandonado à arbitrariedade institucional. Essa identificação está no cerne das ações de desinstitucionalização, características da reforma psiquiátrica. Institucionalizar alguém tornou-se, em outras palavras, o artifício utilizado para anular uma subjetividade até fazê-la o seu correlato lógico (ou seja, até torná-la mero objeto), como aquele que, sem liberdade, apenas sofre a ação de um outro: sendo esse outro, justamente, a própria instituição.

Contudo, desinstitucionalizar não significa apenas desospitalizar, mas principalmente conjurar tanto os processos quanto os efeitos reducionistas da institucionalização (Alarcon, 2008). As críticas feitas aos hospitais psiquiátricos quanto ao tratamento de loucos e dependentes químicos se estendem, por isso, a outras instituições que nasceram à sombra de sua racionalidade, como as comunidades terapêuticas, as clínicas privadas e até mesmo os grupos de mútua ajuda - pois todos em princípio entenderiam a saúde pela simplificação unicausal e institucionalizariam o sujeito.

\section{Serviços de Atenção Psicossociais Comunitários ou Territoriais}

Coerente com os princípios do SUS, a política de atenção integral a usuários de álcool e outras drogas do Ministério da Saúde (Brasil/MS, 2003) foi elaborada em consonância com a lei n. 10.216/01, a III Conferência Nacional de 
Saúde Mental e a portaria n. 336/02, e se mantém coerente ainda hoje, após a IV Conferência Nacional de Saúde Mental.

O texto da lei n. 10.216, marco legal da reforma psiquiátrica, ratificou as diretrizes básicas que constituem o SUS. A lei procura garantir aos usuários de serviços de saúde mental - e, consequentemente, aos que sofrem de transtornos decorrentes do consumo de álcool e outras drogas - a universalidade de acesso e direito à assistência, bem como a sua integralidade, e valoriza a descentralização do modelo de atendimento, determinando a estruturação de serviços mais próximos do convívio social de seus usuários.

O relatório da III Conferência Nacional de Saúde Mental (dezembro de 2001) evidencia, reafirma e reelabora as estratégias e propostas para efetivar e consolidar um modelo de atenção aos usuários de álcool e outras drogas que garanta o seu atendimento pelo SUS e, ao mesmo tempo, considere o seu caráter multifatorial, não reduzindo essa questão a uma problemática exclusiva do sistema de atenção à saúde.

Já a portaria GM/336, de 19 de fevereiro de 2002 (Brasil/MS, 2002), define normas e diretrizes para a organização de serviços que prestam assistência em saúde mental, como no caso dos Caps - incluídos aqui os voltados para o atendimento aos usuários de álcool e drogas, os Caps ad. Por fim, a portaria SAS/189, de 20 de março de 2002 (Brasil, 2004), regulamenta a portaria GM/336, criando, no âmbito do SUS, os serviços de atenção psicossocial para o desenvolvimento de atividades em saúde mental para pacientes com transtornos decorrentes do uso prejudicial e/ou dependência de álcool e outras drogas.

A rede de assistência a pessoas que apresentem problemas decorrentes do uso de álcool e outras drogas é, de modo geral, centrada na atenção comunitária associada à rede de serviços de saúde que tenha ênfase na reabilitação e reinserção social dos seus usuários. De maneira específica, as ofertas de cuidados têm como base dispositivos extra-hospitalares de atenção psicossocial, devidamente articulados à rede assistencial em saúde mental e ao restante da rede de saúde. Tais dispositivos devem fazer uso dos conceitos de território e rede e da lógica ampliada de redução de danos. Devem ainda estar integrados ao meio cultural e à comunidade em que estão inseridos os usuários dos serviços. Além disso, e de acordo com os princípios da reforma psiquiátrica, devem estimular ações intersetoriais.

Segundo o Ministério da Saúde, um Caps ad tem como objetivos: oferecer atendimento à população, respeitando uma área de abrangência definida e dispondo de atividades terapêuticas e preventivas para a comunidade, buscando 
prestar atendimento diário aos usuários dos serviços, dentro da lógica ampliada de redução de danos; gerenciar os casos, oferecendo cuidados personalizados; oferecer atendimento nas modalidades intensiva, semi-intensiva e não intensiva, garantindo que os usuários de álcool e outras drogas recebam atenção e acolhimento; oferecer condições para o repouso e desintoxicação ambulatorial de usuários que necessitem de tais cuidados; oferecer cuidados aos familiares dos usuários dos serviços; promover, mediante diversas ações (que envolvam trabalho, cultura, lazer, esclarecimento e educação da população), a reinserção social dos usuários, utilizando para tanto recursos intersetoriais, ou seja, de setores como educação, esporte, cultura e lazer, montando estratégias conjuntas para o enfrentamento dos problemas; trabalhar, junto com usuários e familiares, os fatores de proteção para o uso e dependência de substâncias psicoativas, buscando ao mesmo tempo minimizar a influência dos fatores de risco para tal consumo; trabalhar a diminuição do estigma e preconceito relativos ao uso de substâncias psicoativas mediante atividades de cunho preventivo/educativo.

Os Caps ad atuam de forma articulada a outros dispositivos assistenciais em saúde mental (ambulatórios, leitos em hospitais-gerais, hospitais-dia) e a dispositivos assistenciais da rede de atenção básica de saúde, como o Programa Saúde da Família (PSF) e o Programa de Agentes Comunitários de Saúde (Pacs).

Também está explícita em seu projeto a articulação em torno dos dispositivos de suporte social já existentes nas comunidades, configurando redes flexíveis de cuidados, que possam responder por um determinado território populacional, e que se remodelem de forma dinâmica, mediante a necessidade de inclusão/exclusão de novos serviços e formas de cuidado, de forma pareada pela demanda assistencial.

Ao conseguir adquirir a característica de serviço aberto e comunitário sob a lógica da redução de riscos e danos, o Caps ad pode, em teoria, oferecer programas terapêuticos de recuperação de dependentes químicos com um grau menor de exigência no que diz respeito às modificações no estilo de vida e à adoção da abstinência, tornando-se, também em teoria, disponíveis para uma quantidade maior de pessoas da comunidade.

\section{Realinhamento das Políticas Públicas}

Se na época em que foi promulgada a lei n. 6.368/76 (Brasil, 1976), os tratamentos possíveis para o uso abusivo ou a dependência química de álcool e 
outras drogas eram unicausais, baseados no modelo hospitalocêntrico ou nos tratamentos morais, e não produziam contradições com a aplicação da lei antidrogas vigente, desde a Constituição de 1988 as condições para definir esse tratamento sofreram mudanças consideráveis, ao menos na esfera pública.

Após a implantação do SUS, surgiu algum desconforto entre os setores saúde e segurança quanto ao problema-drogas. Enquanto a tendência do setor segurança é de intensificar e tornar mais sutil e sofisticado o sistema de interdição às drogas, o setor saúde tende a propor abordagens mais flexíveis e, em geral, mais educativas do que punitivas ou restritivas.

A nova definição de saúde (como qualidade de vida) tornou complexas as abordagens possíveis, conduzindo à ampliação do entendimento do uso de álcool e outras drogas, que, no entanto, não foi acompanhado de forma imediata e profilática por uma reforma da legislação antidrogas.

Esse contexto ajudou a produzir um breve momento dissociativo nas perspectivas pelas quais o poder público tentava basear suas ações para conjurar os efeitos nocivos produzidos pelo uso de álcool e outras drogas. Além dos modelos de atuação na assistência, o que estava em causa era também o modelo legal que deveria sustentar as ações, seja em termos de segurança pública, seja em termos de saúde pública. Um dos resultados dessa dicotomia foi a criação, em 1998, da Secretaria Nacional Antidrogas (Senad), que originalmente era uma agência diretamente vinculada ao Gabinete de Segurança Institucional da Presidência da República (atualmente está vinculada ao Ministério da Justiça), cujo desenho institucional foi baseado na norte-americana Drug Enforcement Administration (DEA). Ao criar a Senad como cópia ideológica da DEA, o governo brasileiro iniciou e concluiu a construção de uma política pública na área da redução da demanda e da oferta de drogas mais alinhada à radicalidade do proibicionismo inerente aos resultados da Conferência de 1961 (a Política Nacional Antidrogas foi instituída em 26 de agosto de 2002, por meio do decreto n. 4.345).

A DEA tem como missão ${ }^{8}$ cuidar para que as leis proibicionistas sejam aplicadas conforme os interesses geopolíticos dos EUA. Historicamente, são

\footnotetext{
8 A missão da Drug Enforcement Administration (DEA) é fazer cumprir as leis e regulamentos para substâncias controladas dos Estados Unidos e encaminhar para o sistema de justiça criminal e civil dos Estados Unidos, ou qualquer outra jurisdição competente, as organizações e os principais membros de organizações, envolvidos no crescimento, fabrico ou distribuição de substâncias destinadas ao tráfico ilícito nos Estados Unidos; e de recomendar e apoiar a execução de programas destinados a reduzir a disponibilidade de substâncias ilícitas nos mercados nacional e internacional. Disponível em:<www.usdoj.gov/dea/agency/mission.htm>. Acesso em: 21 mai 2008. Tradução livre.
} 
os EUA os principais interessados na manutenção das políticas proibicionistas aceitas no mundo, assim como são os patrocinadores da ampla militarização do controle da oferta e da demanda desde as décadas de 1960-1970 (Dudouet, 1999). Porém, se por um lado, para fins de estratégia geopolítica, a militarização do combate às drogas produziu diversos ganhos aos EUA (invasão do Panamá, interferências na Colômbia e Nicarágua etc.), por outro lado é a responsável por uma série de atentados aos direitos do homem, à democracia e ao meio ambiente, especialmente nos países produtores pobres, sejam eles periféricos ou semiperiféricos, como os da Ásia e América do Sul. A interdição às drogas e a sua manutenção através da militarização do processo repressivo alimentaram os lucros das organizações criminosas que financiam e distribuem as drogas no atacado e diversificaram suas atividades, incluindo o tráfico de armas, de seres humanos, de espécies animais e vegetais, de objetos preciosos etc.

Paralelamente à criação da Senad e da Política Nacional Antidrogas (PNA), os técnicos do Ministério da Saúde, baseados nos princípios da reforma sanitária e psiquiátrica, lentamente construíram estratégias para a implantação de serviços para a atenção ao usuário de álcool e outras drogas, acolhendo como filosofia os modelos não alinhados com o proibicionismo.

A partir de 2003, propostas concretas e específicas para a atenção ao portador de transtornos decorrentes do uso de álcool e outras drogas culminaram com a divulgação das diretrizes do Ministério da Saúde, privilegiando a lógica ampliada da redução de danos, inspirada em programa análogo de combate à disseminação do vírus da Aids em população de usuários de drogas injetáveis. A partir da divulgação do plano de diretrizes, a adequação entre a legislação proibicionista e as formas de tratamento se distanciou, ocasionando clara disparidade ético-política entre os pressupostos oriundos das políticas proibicionistas, centrados na droga ilícita e sua proscrição, com aqueles do Ministério da Saúde, centrados no sujeito e sua autonomia.

No bojo dessa dissociação, foi colocado na pauta de discussões políticas o realinhamento entre a PNA e a legislação brasileira sobre drogas. O embate em torno das questões concluiu-se com vantagem para os partidários do proibicionismo. O propalado avanço caracterizado pela eliminação da pena restritiva de liberdade para os usuários de drogas configurou-se, de modo geral, em vitória de Pirro.

A legislação brasileira sobre drogas manteve-se não apenas proibicionista, mas agora aparentemente imune às resistências que antes se colocavam pelo movimento dos redutores de danos. A lei n. 11.343/06 (Brasil, 2006), atualizada pelo Congresso Nacional e sancionada pelo presidente Luiz Inácio Lula da 
Silva, em 23 de agosto de 2006, ao mesmo tempo que enfatiza a adesão ao proibicionismo internacional, instituindo o endurecimento das penas pelo tráfico dessas substâncias (o texto aumenta o tempo de prisão para os traficantes, passando de 3 a 15 para 5 a 15 anos de detenção), trata de aspectos relativos à prevenção, atenção, reinserção social do usuário e dependente de drogas, fagocitando a redução de danos como um aspecto da legislação proibicionista. Embora determine o fim do tratamento obrigatório para dependentes, ao contrário do que se tem divulgado, a nova lei não descriminaliza qualquer tipo de droga. O porte continua caracterizado como crime, estando usuários e dependentes sujeitos a medidas socioeducativas aplicadas pelos juizados especiais criminais. Além disso, institui o Sistema Nacional de Políticas Públicas sobre Drogas, com o objetivo estratégico de garantir que a articulação, integração, organização e coordenação das atividades de prevenção, tratamento e reinserção social de usuários e dependentes de drogas, bem como as de repressão ao tráfico, mantenham-se claramente alinhadas com a Política Nacional sobre Drogas (PND), ou seja, com os compromissos do país com o proibicionismo internacional.

O realinhamento legal manteve o status quo das drogas como mal social, como portadoras de riscos ao indivíduo e à população, e, o que é pior, torna a política de redução de danos do Ministério da Saúde apenas um aspecto coerente de sua formulação, minimizando a potência problematizadora da redução de danos ao convertê-la a mero esforço assistencialista.

\section{Conclusão}

No Brasil, as mesmas premissas que sustentaram uma legislação criminalizante e uma interpretação 'policialesca' do uso de determinadas drogas colocaram-se por trás da constituição de toda uma série de equipamentos de saúde (privados e públicos) coerentes com os objetivos de uma sociedade sem drogas - onde a abstinência total se colocava como único horizonte possível para o tratamento da toxicomania. Sem contradições no início, especialmente durante o período da ditadura militar, as relações entre o setor saúde e o setor segurança permaneceram coerentes até muito tempo depois do início da implantação das reformas sanitária e psiquiátrica. No entanto, as reformas permitiram o desabrochar de uma aparente distensão entre saúde e segurança, exigindo de parte a parte uma abordagem do problema-drogas mais ampla que a simples avaliação 
'especialística' (seja ela do ponto de vista da saúde, da segurança, da sociologia etc.) tomada isoladamente.

As diferenças entre os dois atores, segurança e saúde, podem ser resumidas da seguinte maneira: o setor segurança tem como fundamento para suas ações a legislação antidrogas; como objetivo, uma sociedade sem drogas; como instrumentos para atingir os objetivos, a repressão à oferta, cujo resultado é a guerra ao narcotráfico, e a repressão à demanda, cujo resultado é a criminalização do usuário (cúmplice do traficante); e como modo de ação, o combate antes que o controle (penalização e justiça terapêutica = abstinência total). $\mathrm{O}$ setor saúde tem como fundamento de suas ações os princípios das reformas sanitária e psiquiátrica - portaria n. 336/2002 e diretrizes do Ministério da Saúde para Atenção ao Usuário de Álcool e Outras Drogas (Brasil/MS, 2003); como objetivos, a saúde como qualidade de vida e a cidadania (respeito aos direitos da pessoa); como instrumentos para atingir os objetivos, os dispositivos extra-hospitalares de atenção psicossocial especializada (Caps ad) e territoriais, articulados à rede assistencial em saúde mental e ao restante da rede de saúde; como modo de ação, o controle sendo a única forma de combate, pois o uso de drogas é universal e não pode ser extinto por decreto (lógica ampliada de redução de danos).

A indefinição quanto a uma política pública (unificada) para a questão do dependente químico manteve o campo de atenção indefinido por algum tempo, diante de tensões entre os que preconizavam uma política de abstinência total e os que preconizavam uma política ampliada de redução de danos. Apenas em 2005, com o realinhamento das políticas públicas sobre a questão, firmou-se a PND, que, de certa maneira, minimizou as diferenças entre saúde e segurança, mediante um acordo que reconheceu, apesar das diferenças, certo grau de homogeneidade entre os setores. Assim, a nova PND enfatizou o consenso saúde/ segurança, propondo como orientação geral a promoção de estratégias e as ações de redução de danos voltadas para a saúde pública e direitos humanos, realizadas de forma articulada inter e intrassetorial, visando à redução dos riscos, das consequências adversas e dos danos associados ao uso de álcool e outras drogas para o usuário, a família e a sociedade. Como diretriz, a nova PND propôs reconhecer a estratégia de redução de danos, amparada pelo artigo 196 da Constituição Federal, ${ }^{9}$ como medida de intervenção preventiva, assistencial, de promoção da saúde e dos direitos humanos.

\footnotetext{
9 O artigo 196 da Constituição de 1988 diz que "A saúde é direito de todos e dever do Estado, garantido mediante políticas sociais e econômicas que visem à redução do risco de doença e de outros agravos e ao acesso universal e igualitário às ações e serviços para sua promoção, proteção e recuperação".
} 
Essas medidas permitiram amenizar a lógica ampliada da redução de danos como antípoda do proibicionismo, tornando-a parte do instrumento legal promulgado como lei n. 11.343/06 (Brasil, 2006). Essa lei instituiu o Sistema Nacional de Políticas Públicas sobre Drogas (Sisnad), cuja finalidade é

articular, integrar, organizar e coordenar as atividades de prevenção, tratamento e reinserção social de usuários e dependentes de drogas, bem como as de repressão ao tráfico, mantendo um perfeito alinhamento com a Política Nacional sobre Drogas e com os compromissos internacionais do país [ou seja, com a legislação proibicionista].

Esse realinhamento refaz o antigo acordo entre saúde e segurança vigente no período militar, antes da implantação de um sistema de saúde que deixasse de privilegiar a unicausalidade das doenças. A breve escaramuça que se estendeu entre a promulgação da Constituição de 1988 e a promulgação da lei n. 11.343/06 (Brasil, 2006) não conseguiu encorpar uma real dissidência em relação à visão eminentemente proibicionista. Há de se reconhecer que essa dissidência entre os atores saúde e segurança, na verdade, sempre foi aparente, pois, mesmo que se possa falar hoje de uma mitigação quanto às penas impostas aos usuários das drogas ilícitas e de uma 'evolução' dos tratamentos - que, em termos de política pública, desconsideram a antiga abordagem inflexível para favorecer outra flexível em relação à abstinência -, manteve-se intacto o principal acordo proibicionista, a saber: as drogas continuam sendo consideradas um mal a priori e, como tal, um risco não apenas à segurança, mas principalmente à saúde pública (Alarcon, 2008).

\section{Referências}

AlARCON, S. O Diagrama das Drogas: cartografia das drogas como dispositivo de poder na sociedade brasileira contemporânea, 2008. Tese de Doutorado, Rio de Janeiro: Escola Nacional de Saúde Pública, Fundação Oswaldo Cruz.

BOURDIEU, P. A dissolução do religioso. In: Coisas Ditas. São Paulo: Brasiliense, 1990.

BRASIL. Lei de Entorpecentes, n. 6.368, 21 out. 1976. Disponível em:<www.planalto. gov.br/ccivil_03/leis/L6368.htm>. Acesso em: 29 jun. 2009.

BRASIL. Lei de Entorpecentes, n. 11.343, 18 ago. 2006. Disponível em:<www.planalto. gov.br/ccivil_03/_Ato2004-2006/2006/Lei/L11343.htm>. Acesso em: 29 jun. 2009. 
BRASIL. Ministério da Saúde. Portaria n. 336/GM, 19 fev. 2002. Brasília: Ministério da Saúde, 2002.

BRASIL. Ministério da Saúde. A Política do Ministério da Saúde para a Atenção Integral a Usuários de Álcool e Outras Drogas. 2. ed. revista e ampliada. Brasília: Ministério da Saúde, 2003.

BRASIL. Ministério da Saúde. Legislação em Saúde Mental 1990-2004. 5. ed. ampliada. Ministério da Saúde, 2004.

CASTEL, R. L'Ordre Psychiatrique: l'age d'or de l'alienisme. Paris: Les Editions de Minuit, 1976.

CZERESNIA, D. \& FREITAS, C. M. (Orgs.). Promoção da Saúde: conceitos, reflexões e tendências. Rio de Janeiro: Editora Fiocruz, 2003.

DUDOUET, F-X. La Formation du Contrôle International des Drogues. Déviance et Société, 23(4): 395-419, 1999.

FOUCAULT, M. História da Sexualidade I: a vontade de saber. Rio de Janeiro: Graal, 1985.

FOUCAULT, M. O nascimento da medicina social. In: Microfísica do Poder. Rio de Janeiro: Graal, 1988a.

FOUCAULT, M. Sobre a história da sexualidade. In: Microfísica do Poder. Rio de Janeiro: Graal, 1988b.

KEMP, A. \& EDLER, F. C. A reforma médica no Brasil e nos Estados Unidos: uma comparação entre duas retóricas. História, Ciências, Saúde - Manguinhos, 11(3): 569-585, set.-dez. 2004.

NASSIF, A. C. N. Projeto Flexner brasileiro. 2006. Disponível em:<www.escolasmedicas. com.br/artigos.asp?cmd=view\&articleid=22>. Acesso em: 6 out. 2007.

ORGANIZAÇÃO MUNDIAL DA SAÚDE (OMS). Declaração de Alma-Ata. In: CONFERÊNCIA INTERNACIONAL SOBRE CUIDADOS PRIMÁRIOS DA SAÚDE. Alma-Ata, URSS, 6-12 de setembro de 1978. 


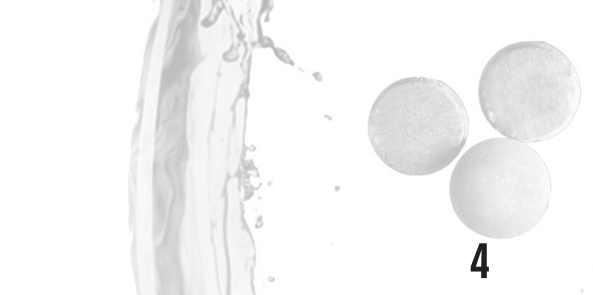

\title{
Higiene e Eugenia: \\ brevíssima genealogia da trama discursiva antialcoólica no Brasil
}

\author{
Alexandre Magno Teixeira de Carvalho
}

O corpo só se torna força útil se é ao mesmo tempo corpo produtivo e corpo submisso

Michel Foucault

\section{Alcoolismo e o Alcoolista}

Segundo Souza (2004), a cachaça (catuta, meles, remédio, restilo, vinhos etc), nascida em terras brasileiras pelas mãos dos portugueses durante o período colonial e muitas vezes usada como moeda nas trocas do tráfico negreiro,

consolidou-se como um produto de baixo status não apenas em termos de consumo, mas também de produção. Sua própria distribuição e venda se deu, muitas vezes, às margens da lei ou em pequenos estabelecimentos, agregando, em síntese, os desclassificados e marginalizados do sistema. ${ }^{1}$ (Souza, 2004:2)

Dessa forma, são relativamente escassos os documentos que se referem a casos de embriaguez entre os membros das elites. O consumo de bebidas alcoólicas pelas elites coloniais não era 'condenável'. Ao contrário, seu emprego era

\footnotetext{
1 De qualquer forma, pode-se dizer que a cachaça teve um papel de relativa importância no sistema econômico ligado à produção de açúcar, mais conhecido como ciclo da cana-de-açúcar, com destaque para a produção de regiões como Campos e Parati (Scwhartz, 1994).
} 
considerado medicinal, de forma coerente com as teorias miasmática e humoral ${ }^{2}$ que orientavam o saber médico de então. O 'alcoolismo' socialmente condenado durante os períodos do Brasil Colônia e do Brasil Império era o 'alcoolismo' (os excessos e os perigos) dos pobres, dos escravos, dos homens do povo.

Há de se perguntar o leitor: por que a palavra alcoolismo aparece entre aspas no parágrafo anterior? Simplesmente porque não havia, como se concebe hoje em dia, a ideia de alcoolismo. A leitura de textos de historiadores permite inferir, sem dúvida, que o problema do alcoolismo, nas épocas colonial e imperial, não era uma questão eminentemente médica. Tampouco havia a figura do alcoólatra. O 'alcoólatra' é um sujeito inventado. 'Alcoolista' era o termo mais usado pelos neuro-higienistas. No Brasil, esse sujeito social foi construído durante as primeiras décadas da República. Portanto, a figura do alcoólatra contemporâneo não se confunde com a figura do beberrão, por exemplo. Do ponto de vista contemporâneo, o alcoolismo é uma doença, e o alcoólatra, um doente. Contudo, essa concepção, do ponto de vista histórico, é bastante recente, ou seja, foi há pouco mais de cem anos que o alcoolismo se tornou um problema médico, ${ }^{3}$ e o alcoólatra, um potencial paciente, alvo de ação da medicina.

Em 1923, o médico e deputado federal Carlos Penafiel argumentava: "10) O alcoolismo é uma doença moral e seu remedio está na educação; $2^{\circ}$ ) o alcoolismo é uma doença social e seu remedio está na ordem" (LBHM, 1925a: 151). ${ }^{4}$ A enunciação desses princípios expressava uma passagem da questão alcoólica da esfera dos costumes para a dimensão de um saber médico-moral. Essa passagem foi, igualmente, fruto de um processo de intervenção crescente da medicina no campo social. ${ }^{5}$ Em 1929, Juliano Moreira definia o alcoolismo

\footnotetext{
2 A cachaça, acreditava-se, continha 'humores quentes', que, combatendo os males dos humores frios segregados pelo corpo, seriam benéficos à saúde. Esse conhecimento se baseava nas ideias hipocráticas, cujas origens remontam ao século $V$ a.C., e segundo as quais a doença correspondia a uma perturbação do equilíbrio da natureza (physis). A doença fazia parte da natureza do homem, não lhe era exterior. A boa saúde, nessa concepção, dependia do equilíbrio dinâmico dos humores: sangue, fleuma, bile amarela e bile negra.

3 Henrique Roxo, em 1925, dizia que "tres grandes factores [são] salientes nas genesis de doenças mentaes: a syphilis, o alcoolismo e o espiritismo" (Roxo, 1925: 2). Curioso, não? Mas esta é uma outra história...

4 Texto originalmente publicado no Jornal do Commercio, em 16 de dezembro de 1923 (LBHM, 1925a: 147).

5 A medicina social que nasceu no Brasil tinha como modelo a higiene pública francesa, pela qual a higiene mental brasileira nutria especial apreço. Certamente não foi por acaso a escolha de Belo Horizonte, primeira utopia urbanística da nação, planejada por uma equipe de engenheiros e sanitaristas nos moldes do esquadrinhamento urbano francês, para sediar
} 
como "doença social" e"endemia social"6 (Moreira, 1929). Além do mais, deve-se considerar que, na década de 1920, a teoria do contágio, embalada pelo sucesso 'microbiano' de Pasteur, vencera, depois de séculos, a teoria miasmática e estava a desbancar a teoria humoral que vigorava desde Hipócrates. Antes potencialmente terapêutica e benéfica, um verdadeiro remédio, a cachaça tornava-se um veneno e um malefício.

$\mathrm{Na}$ "Bibliographia brasileira do alcoolismo", organizada por Ernani Lopes (1925a), o texto médico mais antigo ${ }^{7}$ sobre alcoolismo data de 1884:"Do alcoolismo chronico e suas consequencias", tese de Loureiro Alves. O seguinte, na ordem cronológica, data de 1897. Porém, foi durante as décadas de 1910 e 1920 que houve uma intensa produção de textos médicos sobre o alcoolismo. ${ }^{8}$ Destes, selecionamos os presentes nos Archivos Brasileiros de Hygiene Mental (ABHM), durante a década de 1920. Ao longo desse período, todos os artigos mencionavam o problema do alcoolismo. Higiene mental no Exército, higiene escolar, legislação sobre imigração, epilepsia, melhoria da prole, trabalho humano etc, não importava o tema lá estava sempre presente, com mais ou menos ênfase, a questão antialcoólica. Ademais, havia nos ABHM uma única "Secção permanente": "CONTRA O ALCOOLISMO: EM FAVOR DA HYGIDEZ MENTAL", cujas primeiras linhas diziam o seguinte:

A "Liga Brasileira de Hygiene Mental" não podia deixar de preoccupar-se desde o seu inicio com a questão do alcoolismo, sabidos como são os multiplos maleficios do terrivel veneno inebriante sobre o systema nervoso, em particular sobre a mentalidade. (LBHM, 1925a: 147)

Como veremos, o combate ao alcoolismo, que consagrou no interior da LBHM e no meio médico a expressão "luta anti-alcoolica", ${ }^{9}$ fundava-se nos princípios (pretensamente universais e necessários) da higiene mental e da eugenia.

o $2^{\circ}$ Congresso Brasileiro de Hygiene (CBH), em 1924. Nesse congresso, a higiene mental foi incluída "como um dos themas officiaes" (LBHM, 1925b: 193). Esposel (1925) também considerava o $2^{\circ} \mathrm{CBH}$ como um marco para a higiene mental no Brasil.

6 "(...) uma das mais damninhas endemias sociaes: o alcoolismo" (Moreira, 1929: 61).

7 A despeito de ser realmente o 'mais antigo', trata-se efetivamente do primeiro a ser registrado nos anais da LBHM.

$875 \%$ dos textos que constam da bibliografia organizada por Ernani Lopes datam das décadas de 1910-1920.

9 Em 1929, a "secção de anti-alcoolismo" da LBHM contava, entre outros, com os nomes de Miguel Couto, Afranio Peixoto, Fernando Magalhães, Evaristo de Moraes, Erasmo Braga e Moncorvo Filho. Quase todos, hoje, emprestam seus nomes a ruas e/ou unidades hospitalares do Rio de Janeiro. 
Segundo Farani, "A eugenia é a segunda etapa das aspirações da hygiene. A primeira ficou constituida pela melhoria do individuo, graças à prevenção das doenças; a eugenia visa a melhoria da especie" (Farani, 1925: 39). Renato Kehl definia a eugenia como a "sciencia da bôa geração" que "para a consecução de seus desígnios seleccionistas estabelece a selecção dos genitores":

À eugenia incumbe pois, a puericultura ante-concepcional e intra-uterina, como à agricultura se impõe, principalmente, a selecção e protecção das sementes, como à zootechnia se impõe, inicialmente, a escolha dos reproductores e a segregação dos que não conveem. (Kehl, 1925: 70)

Desse ponto de vista, o álcool e o alcoolismo eram considerados fatores "deseugenisantes" das espécies a serem combatidos. Para que essa ideia vingasse foi necessária uma forte propaganda, pois, "mesmo entre a classe medica, a maioria dos profissionaes" ignorava a "importância dos ensinamentos anti-alcoólicos" (LBHM, 1925a: 148-150), bem como "o magno problema da creação da elite eugenica" (Kehl, 1925: 71).

\section{A Liga Brasileira de Hygiene Mental: texto e contexto}

Ao fim da I Guerra Mundial, o Brasil era um país abalado pelas profundas transformações nas relações político-econômicas internacionais (nas quais o evento da Revolução Russa desempenhou importante papel) ${ }_{10}^{10}$ pelas disputas no interior das próprias oligarquias dominantes ${ }^{11}$ e pelo crescimento do número de estabelecimentos industriais e consequente incremento da população urbana. Nesse contexto, ganharam novo vigor os ideais de ordem, progresso, nacionalismo e grandeza que embalavam o sonho republicano.

No grupo de países menos desenvolvidos do ponto de vista industrial, as relações capitalistas se expandiam, ao mesmo tempo que as formações econômico-sociais pré-capitalistas ${ }^{12}$ se debilitavam, passando a burguesia a disputar participação efetiva no poder.

10 O risco de internacionalização do regime soviético que surgiu a partir da Revolução de Outubro acabou deflagrando ações enérgicas da burguesia mundial.

11 Albuquerque (1986) chama a atenção para a importância "das rivalidades oligárquicas" como expressão de conflitos políticos generalizados, em meio a um quadro de instabilidade econômica e financeira.

12 Sobre o conceito de "formações econômico-sociais pré-capitalistas", considerar as definições de Marx (1986) e as contribuições de Hirano (1988) e Albuquerque (1986). 
Segundo Albuquerque (1986: 442),

a partir das transformações produzidas na Formação Social Brasileira pela Primeira Guerra Mundial (1914-18), a dominância dos setores agrários começou a declinar em benefício da burguesia industrial e financeira, cuja hegemonia se tornou incontestável a partir da Revolução de 1930.

Na década de 1920, a crise do projeto constitucional de uma república democrático-representativa e federativa já era evidente diante de uma realidade política oligárquica voltada, essencialmente, aos interesses econômicos imediatos de uma elite agrícola. A rigor, a estrutura democrático-liberal da Primeira República não passava de um poderoso instrumento político destinado a resguardar os interesses específicos da economia cafeeira. ${ }^{13}$

No entanto, além das forças conservadoras e das forças econômicas emergentes - defensoras de uma nova ordem sustentada por um "progresso renovador dos princípios e dos métodos de ação” (Lindolfo Collor apud Silva, 1965:448) -, agitavam-se forças ditas ‘subversivas'. Em 1922, realizara-se a Semana de Arte Moderna, abrindo novas possibilidades de pensar e agir a partir de uma revolução ético-estética e cultural. ${ }^{14}$ Era também o ano de fundação do Partido Comunista. ${ }^{15}$

Ao caldo de cultura brasileiro acrescentar-se-iam, além das forças citadas, as características de uma formação social mesclada e complexa que, segundo Carvalho, bem sabia que

\footnotetext{
13 A intervenção do poder público na economia, mesmo sob a égide de um Estado que se propunha liberal, era frequentemente requisitada de acordo com os interesses privados, principalmente em se tratando de valorização de monoculturas, de política imigratória, tarifária e cambial (Carvalho, 1997).

14 Para Albuquerque, "tal como ocorreu em outros setores, as opções políticas dos modernistas também se manifestaram posteriormente. Se a maioria aceitou as mudanças conformando-se com o direcionamento de direita que lhes foi imprimido, outros, como Oswald de Andrade, optaram por um encaminhamento da questão social em termos teóricos marxistas" (Albuquerque, 1986: 557). Já para Tristão de Ataíde (apud Lima, 1976: 339), "o movimento estético 'modernista' está ligado ao movimento político 'tenentista'. O mesmo anseio secreto - já inicialmente patente - de mudanças das estruturas literárias e plásticas ocorre com as estruturas políticas. A República Velha aproxima-se do fim, como se prepara a demolição da Arte Velha. O crepúsculo de ambas caminha pari-passu. O ambiente civil está maduro para uma mudança radical de estruturas" (Tristão de Ataíde apud Lima, 1976: 339).

15 Apesar de se verificar, a partir de 1920, segundo Lobo, "um declínio das organizações e do movimento operário, se for visto apenas pela ótica do número de greves, manifestações de rua e das instituições, geralmente atribuído pelos analistas como decorrente do enfraquecimento dos anarquistas, da divisão provocada pela formação do PC e do aprofundamento da repressão devido às ameaças à segurança nacional representadas pelas revoltas tenentistas de 1922 e 1924" (Lobo, 1992: 22-23).
} 
o formal não era sério. Não havia caminhos de participação, a República não era para valer. Nessa perspectiva, o bestializado era quem levasse a política a sério, era o que se prestasse à manipulação. Num sentido talvez ainda mais profundo que o dos anarquistas, a política era tribofe. Quem apenas assistia, como fazia o povo do Rio por ocasião das grandes transformações realizadas a sua revelia, estava longe de ser bestializado. Era bilontra. ${ }^{16}$ (Carvalho, 1996: 160)

Para Oswald de Andrade, um dos principais articuladores da Semana de Arte Moderna,

a situação 'revolucionária' desta bosta mental sul-americana apresentava-se assim: o contrário do burguês não era o proletário - era o boêmio! (...) Com pouco dinheiro, mas fora do eixo revolucionário do mundo, ignorando o Manifesto Comunista e não querendo ser burguês, passei naturalmente a ser boêmio (...). Do meu fundamental anarquismo jorrava sempre uma fonte sadia, o sarcasmo. Servi à burguesia sem nela crer. Como o cortesão explorado cortava as roupas ridículas do regente (...). O brasileiro à-toa na maré alta da última etapa do capitalismo. Fanchono. Oportunista e revoltoso. Conservador e sexual. Casado na polícia. Passando de pequeno-burguês e funcionário climático a dançarino e turista (...) Eu prefiro simplesmente me declarar enojado de tudo. E possuído de uma única vontade. Ser, pelo menos, casaca de ferro na Revolução Proletária. (Andrade, 1973: 111-114)

Sérgio Buarque de Holanda, em 1936, analisando a herança ibérica de nossa cultura, afirmava a existência de uma "alma comum, a despeito de tudo quanto nos separa" e assinalava:"o que predomina é a concepção antiga de que o ócio importa mais do que o negócio e de que a atividade produtora é, em si, menos valiosa que a contemplação e o amor" (Holanda, 1993: 10).

Renato Kehl, ${ }^{17}$ fundador da Sociedade Eugênica de São Paulo, inspetor sanitário do Departamento Nacional de Saúde Pública (DNSP) e conselheiro executivo da LBHM, por sua vez, assim se pronunciava:

\footnotetext{
16 Bilontra: espertalhão, velhaco, gozador, tribofeiro.

17 Para se ter uma ideia do prestígio de Renato Kehl, basta dizer que foi merecedor de um verbete no Lello Universal, dicionário enciclopédico luso-brasileiro produzido em associação com a Livraria Larousse e "sôbre moldes inteiramente eguaes aos do Larousse Universal": "Medico e publicista brasileiro, n. em 1889. Fundou em S. Paulo a primeira Sociedade Eugenica creada na America do Sul. A sua obra scientifica e litteraria é muito extensa" (Lello Universal, s.d.: 1.443).
} 
no Brasil há muito que ponderar, eugenicamente, a bem do futuro da nacionalidade. Paiz de intensa mestiçagem e immigração, ambas processadas à la diable, encontra-se hoje numa confusa situação racial e social, nada brilhante. (Kehl, 1931:96)

Contra a modernidade voluptuosa do grupo Pau Brasil (Oswald de Andrade, Tarsila do Amaral, entre outros não menos antropófagos), a modernidade científica, ordenada e eugênica dos neuro-higienistas, dispostos a realizar, conforme os artigos $1^{\circ}$ e $2^{\circ}$ dos estatutos da LBHM,

um programma de Hygiene Mental e de Eugenetica no domínio das actividades individual, escolar, profissional e social", atuando "junto aos poderes publicos federaes, estadoaes e municipaes, suggerindo medidas e obtendo realizações. ${ }^{18}$ (LBHM, 1925d: 223).

Em uma sociedade industrial emergente,

a extensão do campo da psiquiatria à normalidade tenta viabilizar esse novo projeto através do conhecimento das causas da doença mental e da anormalidade, e de medidas de combate à doença mental, ao grande contingente de improdutivos e à alta taxa de criminalidade dela derivados, compreendidos como empecilhos para a implantação da nova ordem social, através da higiene mental. (Portocarrero, 1980: 154)

Foi nesse contexto, portanto, que surgiram a LBHM e os seus textos - os ABHM. De acordo com diversos autores (Costa, 1976; Engel, 1993, 1995; Reis, 1994; Carvalho, 1999), a LBHM, fundada em 1923, ${ }^{19}$ foi a instituição mais expressiva da produção psiquiátrica higienista da época. Gustavo Riedel, seu primeiro presidente, fora "incumbido" por Clifford Beers ${ }^{20}$ "de fundar na America do Sul a

\footnotetext{
18 O quadro de membros honorários da LBHM foi construído estrategicamente. Esse grupo contava, além do presidente da República Arthur Bernardes, com três ministros de Estado (Felix Pacheco, João Luiz Alves e Pires e Albuquerque, dois senadores, (Conde de Frontin e José Euzébio, dois deputados (Carlos Maximiliano e Clementino Fraga), o prefeito do Distrito Federal (Alaor Prata), dois conselheiros municipais (Cesário de Mello e Mario Piragibe), um representante do funcionalismo público (Pereira Jr.) e três representantes da indústria e do comércio (Guilherme Guinle, Affonso Vizeu e Antônio Gomes Pereira).

19 A Câmara dos Deputados, pelo decreto n. 4.778, de 27 de dezembro de 1923, reconheceu a LBHM como de utilidade pública (LBHM, 1925d:223).

20 Atribui-se a Clifford Beers a criação da higiene mental, nos Estados Unidos, mais precisamente em Connecticut, em 1908.
} 
primeira Associação de Medicina Social (...) com a denominação de Liga Brasileira de Hygiene Mental" (LBHM, 1925c: 210). Os ABHM, publicações periódicas inauguradas em 1925, circulavam em todos os estados, "levando a todos os recantos do Brasil a opinião, os appellos e conselhos dos nossos mais eminentes neuro-hygienistas". Além disso, exerciam "uma função confraternisadora internacional (...) estabelecendo permutas e intensificando relações com as principaes bibliothecas e sociedades scientificas do mundo" (LBHM, 1929). Órgão oficial da LBHM, principal instrumento para "consecução dos seus objetivos (...), destinado sobretudo a orientar os que desejem collaborar na campanha pela hygiene mental", constituindo "não só um repositorio do que se publique em nosso meio, ou alhures, mas tambem, si possivel, um nucleo de atracção de proselytos, no amplo dominio dessa Hygiene Mental, que com justo direito aspira tornar-se a moral universal de ámanhã" (LBHM, 1925e).

O editorial de outubro de 1929 era ainda mais incisivo:

Os 'Archivos', como órgão official da Liga Brasileira de Hygiene Mental, têm uma grande e nobre missão a realizar: órgão de doutrina e de combate, elles se propõem a abrir, em nosso meio, a senda por onde possam enveredar, crescer e frutificar os ideaes de hygiene mental e eugenia que consubstanciam o programma d'aquella Instituição. (LBHM, 1929:57)

\section{Eugenia e Alcoolismo}

Durante a I Guerra Mundial e imediatamente após o seu término, surgiram, no contexto internacional, movimentos que, problematizando a noção de nacionalidade, enfatizavam a questão racial e atribuíam às condições de saúde das populações papel relevante. No Brasil, esses movimentos se organizaram sob a forma de ligas, ${ }^{21}$ reunindo representantes da elite intelectual e política do país. Nesse processo de construção de uma nova ordem nacional, a ciência e, mais especificamente, a medicina, desempenharam papel fundamental ${ }^{22}$

21 Por exemplo, Liga de Defesa Nacional (1916), Liga Nacionalista de São Paulo (1917), Propaganda Nativista (1919), Liga Pró-Saneamento (1919) e Ação Social Nacionalista (1920).

22 Segundo Lima e Hochman (1996:25), "o papel atribuído ao médico não pode ser dissociado da crítica à República, especialmente dirigida à adoção do federalismo na Carta Constitucional de 1891. O federalismo teria propiciado, na perspectiva de importantes intelectuais do período, a oligarquização da política, consistindo numa solução artificial e incompatível diante do que entendiam ser a realidade brasileira. (...) Atribuir à ciência, mais especificamente à medicina, 
(Lima \& Hochman, 1996). Muito mais do que um fenômeno isolado, portanto, o surgimento da LBHM concretizou um front a mais incorporado a diversos movimentos nacionalistas que eclodiram no país entre as décadas de 1910-1920.

A eugenia, entretanto, ainda que ajustemos as lentes da história, não deixa de ser uma forma de racismo cientificista. Desse ponto de vista, concorda-se plenamente com Wallerstein (2001:69), quando sustenta que "o racismo foi um pilar cultural do capitalismo histórico".

Embora as ideias higienistas e eugenistas aparecessem geralmente sobrepostas nos textos da época, havia divergências no interior desses movimentos elitistas. De um lado, uma 'preocupação social', filantrópica, como seria de se esperar de homens de 'boa indole' e de 'boa vontade', emergia na superfície do discurso, forçando o afastamento do discurso eugênico puro. Nem por isso as estratégias de intervenção seriam brandas:

Poder-se-hia, entretanto, com ou sem auxilio dos poderes públicos, attenuar uma parte dos effeitos do mal. Primeiro retirando os filhos dos pais notoriamente ébrios contumazes, tal qual propoz Henri Monod. Fundar-se-hiam, para esse fim, sociedades ou ligas com o intuito de entregar as crianças a familias honestas, sobrias e laboriosas. É uma das iniciativas mais urgentes. (LBHM, 1925a: 147)

Além disso, era recomendável "a creação de asylos para os bebedores incorrigiveis, pelo feitio de Ellikon, pelo feitio de Frelox, e de tantos outros estabelecimentos congeneres" (LBHM, 1925a: 147). Os países mais desenvolvidos economicamente davam régua e compasso. Apesar de serem os resultados sabidamente duvidosos, valia a pena em nome da nova ordem social:

É exacto que o resultado obtido por estes asylos, tanto na Suissa como na America do Norte, não tem sido grande cousa, pois vale mais ou menos pelo seguinte: doentes curados, um terço; sahidas com risco de recahidas, um terço; doentes que sahem incurados, outro terço (...). Em todo caso trata-se dum bom palliativo, a que no interesse collectivo e dos proprios doentes a sociedade precisa recorrer. (LBHM, 1925a: 147)

o papel-chave numa nova organização nacional, parece sugerir ainda um novo elemento de oposição. De fato, no discurso da elite médica do período, era comum o descontentamento com a subordinação das áreas de educação e saúde ao Ministério da Justiça e Negócios Interiores, visto como uma agência dominada pelos políticos e pelos bacharéis". 
Alguns, baseados na ideia de seleção natural, erguerão a voz contra a 'filantropia' (que, desse ponto de vista, apenas favorecia a perpetuação dos "inaptos" e "degenerados", atrapalhando o processo de desenvolvimento do "paiz") e defenderão a eliminação dos menos aparelhados para o social e "saudavel" convívio, propondo a máxima e radical eugenia. Esposel propunha que "tomadas as coisas no tempo, poderia incluir a Liga de Hygiene Mental pugnar com mais vehemencia pela incapacidade matrimonial dos degenerados (...) cuja herança é conhecida e conduz à formação de familias desequilibradas" (Esposel, 1925: 103).

Farani, ao defender a "prophylaxia ante-concepcional", argumentava que depende exclusivamente dos antecedentes paternos o futuro do producto concepcional (...) de modo que torna-se necessário escolher procreadores bons. A eugenia encarrega-se justamente de prevenir os maleficios das uniões indevidas, hygienicamente falando, por meio de uma serie de preceitos sobejamente conhecidos. A eugenia encarrega-se de collocar em presença cellulas germinativas sãs (...) capazes de alterar, por sua juncção o producto concepcional. (Farani, 1925: 39)

Kehl defendia a "esterilização dos degenerados e criminosos". A lista incluía, além dos "degenerados alcoolistas", também os "leprosos, loucos, idiotas, epilepticos, cancerosos, nephriticos tuberculosos, prostitutas, vagabundos". O fundador da Sociedade Eugênica de São Paulo tinha certeza de que seria um dia "adoptada a esterilização como já o foi em certos Estados da União Americana" (Kehl, 1925) e definia:

A esterilização dos degenerados e criminosos constitue uma das medidas complementares da politica eugenica, a qual estabelece, precipuamente, o exame de sanidade pre-nupcial, o impedimento à paternidade indigna, à procreação, em summa, de cacoplastas e desgraçados. (Kehl, 1925: 70)

Não foi, todavia, a eugenia radical que se tornou hegemônica. Além das resistências internas, havia forças sociais ideologicamente contrárias. Sobre as resistências, assim se pronunciava Kehl:

Há rijos preconceitos que desafiam a ponderação como as pyramides pharaonicas resistem às depredações do tempo (...). Quando se levanta a hypothese ou se suggere a necessidade de revogar um principio tradicional, substituindo-o por outro moderno, consentaneo com o progresso da epoca, 
trovejam, por parte de intolerantes, invectivas condemnatorias e, por parte de indifferentes, signaes de descrença ou de pouco caso. (Kehl, 1925:69)

Como se pode notar, o 'moderno', o científico, o novo eram evocados em nome do progresso, em favor de uma nova ordem e contra as resistências, designadas 'tradicionais' e até mesmo 'intolerantes'. A rica composição étnica e sociocultural do povo brasileiro era outro fator que dificultava a defesa das ideias de eugenia radical - até mesmo pelo prejuízo potencial ao processo de produção do capital. No entanto, apesar das condições adversas ao discurso eugênico radical, a ideologia do "embranquecimento" persistiu (Costa, 1976).

\section{Alcoolismo, Trabalho e Capital}

Tão importante quanto o papel do alcoolismo na gênese das doenças mentais, era, para a LBHM, a questão do alcoolismo entre os trabalhadores pobres, em virtude de seu potencial desestabilizador da ordem social e das forças produtivas. Aquele que se desviava da 'ordem', ainda que não de forma organizada, era potencialmente perigoso para o 'progresso' da nação. Ernani Lopes, visando o indivíduo alcoolista "degenerado", argumentava: "contra esses pobres seres a unica therapeutica é a de ordem assistencial: reclusão durante certo prazo e depois liberdade vigiada, durante outros periodos" (Lopes, 1929: 15).

Para combater a "degenerescencia", no entanto, era preciso estudar as "predisposições hereditarias" associadas aos "disturbios mentaes" e suprimi-las pela ação da "eugenetica". Valorizava-se o papel da "educação geral do publico", processo pedagógico que incluía considerações gerais sobre o modus vivendi "mais indicado aos predispostos" (alcoolistas, sifilíticos, pequenos psicopatas, enfim, "mentaes" de toda ordem). Isso pressupunha intervenção na "vida collectiva", nos interstícios da sociedade, afinal,

são, de facto, numerosos os casos de psychopathas que não sabem que o são, ou que o são, mas não o confessam, ou que simplesmente não têm energia para ir à consulta de um medico. São esses casos que o serviço social de informações tem o dever de descobrir nas familias, nas escolas, nas fabricas, etc., afim de os encaminhar, por uma "doce violencia", à presença do psychiatra. (Lopes, 1925b: 170) 
Henrique Roxo defendia que

Os disturbios mentaes, se reconhecidos em seus primordios, são mais facilmente curaveis e nos ambulatorios frequentados pelos predispostos poderão ser elles mais prematuramente surprehendidos. Se não ha uma legislação que impeça o casamento de degenerados, no entanto deveriam os medicos de cada familia aconselhar que se inquirisse do estado de saude dos noivos, a evitar que se creasse uma familia de psychopathas. No periodo da gestação deve o clinico ministrar conselhos que evitem a ingestão de toxicos e poupem as causas de ordem moral que acarretem a degeneração da prole. Na vida profissional deve haver uma selecção experimental dos que se votarem a cada qual, sendo utilizaveis psychologos praticos que investiguem a capacidade intellectual, a facilidade de attenção, a iniciativa, as funcções sensoriaes, a resistência à fadiga, o gráo de suggestibilidade, etc. Deveria haver serviços officiaes de psychologia experimental, a que recorreriam os chefes de serviço na racional selecção dos seus auxiliares. Não se trata unicamente de melhor os adaptar a cada serviço, mas tambem de evitar que se enervem num esforço improficuo e de comprehender os menores disturbios psycho-neurosicos que os condicionem como psychopathas. (Roxo, 1925: 7)

Juliano Moreira vinculou a psiquiatria brasileira ${ }^{23}$ à corrente alemã, incrementando a discussão sobre a etiologia das doenças mentais e promovendo um deslocamento epistemológico da esfera moral para a da biologia. Segundo Amarante, "o biologicismo, tendência predominante da tradição alemã, passa a explicar não só a origem das doenças mentais, mas também muitos dos fatores e aspectos étnicos, éticos, políticos e ideológicos de múltiplos eventos sociais" (Amarante, 1994: 77-78).

Ernani Lopes, diretor presidente da LBHM em 1929, compartilhava dessa referência discursiva. Em discurso proferido em reunião da seção de antialcoolismo (reunião essa, aliás, presidida por Juliano Moreira), na qual abordou a relação entre alcoolismo e saúde física e mental dos trabalhadores pobres, acentuava que era preciso "mostrar o erro dos que desprezam o criterio biologico, na preoccupação unilateral de um economismo incapaz de explicar todas as questões sociaes" (Lopes, 1929: 14). A formulação das concepções de "anormali-

23 Até então, mais afeita aos franceses (Carvalho, 1997). 
dade patológica" e de "potencialidade de degeneração" reforçava esse ponto de vista. Contudo, de acordo com Portocarrero,

a concepção de 'anormalidade' corresponde, mais do que à questão da causalidade, à necessidade de se combater, preventiva e profilaticamente, os problemas sociais decorrentes do comportamento indisciplinável dos indivíduos que não podiam ser considerados loucos propriamente, nem tampouco normais. (Portocarrero, 1980: 151)

Não se tratava mais, portanto, apenas de asilar e excluir (embora a forma do asilo permanecesse viva e mesmo sofisticada, por meio da criação da colônia agrícola e do manicômio judiciário), ${ }^{24}$ mas também de disciplinar e de produzir indivíduos para um novo espaço-tempo econômico e social.

Juliano Moreira, que também era membro fundador da LBHM, em artigo sobre o alcoolismo, acentuava a importância da proteção à "bôa saude mental, fonte de energia productiva" (Moreira, 1929: 61) que estaria na base da modificação radical da antiga concepção social da loucura e dos distúrbios mentais, levando à transformação das diretrizes na "assistencia aos psychopathas". Nessa perspectiva, o trabalho deveria ser, simultaneamente, meio e fim do processo terapêutico e profilático:

O sanatório especial deve ser construido de modo a ser um verdadeiro reformatorio, com installações proprias a manter os internados em actividade laboriosa (...). Officinas varias para os que tiverem maior aptidão para os trabalhos manuaes ou para os que para isto tiverem predilecção. Essas Officinas serão a um tempo um centro de orientação profissional e uma verdadeira escola de aptidão a tal officio (...). Auxiliaremos os esforços dos poderes publicos para attenderem ao problema cada vez mais premente da melhora da capacidade profissional dos nossos artifices e trabalhadores do campo. (Moreira, 1929:62)

A metáfora que assemelhava o homem a uma máquina psicofísica que deveria atingir um funcionamento ótimo era recorrente, como se pode notar nas palavras de Carlos Penafiel: "O homem não trabalha, sinão muito raramente, como um motor physico na agitada e constante vida das fabricas:

24 Segundo Jurandir Freire Costa, entre 1912 e 1920 "são inaugurados a Colônia do Engenho de Dentro, a Colônia de Jacarepaguá e o Manicômio Judiciário” (Costa, 1976: 25). 
trabalha e operará cada vez mais como um apparelho psyco-physiologico" (Penafiel, 1925: 11).

A "conducta" correta, mecanicamente produzida com fins de adaptação à ordem social que se impunha, estava na base do conceito de "saude mental”. Saúde mental, naquele momento, não significava um campo de saberes e práticas, mas sim um estado ou condição mental que constituir-se-ia pela disciplinarização dos indivíduos. Para Fontenelle, inspetor do Departamento Nacional de Saúde Pública (DNSP) e membro da LBHM, "o problema de hygiene mental considera os dois elementos que se relacionam: a estructura psychica do individuo, não raramente deficiente e imperfeita, dependendo em grande parte da hereditariedade; e o meio physico e sócial" (Fontenelle, 1925: 2).

Assim sendo,

O raciocinio justo e deliberação correcta podem desenvolver-se pelos mesmos processos que aperfeiçoam a dextreza manual (...). A mentalidade desenvolvida correctamente, e actuando por meio de reacções convenientes, traduz-se no comportamento mais adequado ao ajustamento do indivíduo ao meio physico e social, exhibindo o que se póde chamar a saude mental.

(Fontenelle, 1925:3)

Portanto, ajustar o indivíduo ao meio físico e social era transformá-lo em um trabalhador forte e dócil. Tecnologia política sustentada por 'avançadas' concepções teórico-morais: estavam lançadas as bases 'ortopédicas' ${ }^{25}$ para uma boa disciplina do corpo e da alma. De acordo com Foucault, o investimento político do corpo se relaciona, de forma complexa e recíproca, à sua utilização econômica. Um corpo só se constitui como força de trabalho quando inserido em um sistema de sujeição:"o corpo só se torna força útil se é ao mesmo tempo corpo produtivo e corpo submisso" (Foucault, 1987:28).

Ao propor uma ação 'profilática' na sociedade, sobretudo sobre os "pequenos psychopathas", categoria na qual se encaixava o alcoólatra, o discurso da Higiene Mental idealizava um duplo movimento do ponto de vista econômico: diminuição do número de ingressos nos manicômios - diminuindo os custos do Estado - e crescimento econômico das nações, fosse impedindo a interrupção de "carreiras" fecundas e "productivas", fosse trabalhando na "producção de

25 'Ortopédico' em alusão aos termos "ortopedia social" e "sociedade da ortopedia generalizada”, cunhados por Michel Foucault em Vigiar e Punir (1987). 
energias uteis". A sociedade - pensada como somatório de indivíduos - se organizaria a partir do funcionamento ideal de seus componentes:

Na organização social deve haver perfeito synchronismo no esforço de todos os seus componentes, [pois] a deficiencia de uns repercute sobre o conjuncto, resultando d'ahi um minoramento na producção de energias uteis. Por isso a psychopathia é uma grande causa de deficit economico das nacionalidades. (Lopes, 1925b: 168)

O discurso médico-moral do primeiro período republicano sobre a questão alcoólica era uma questão contraditória e de classe, ${ }^{26}$ como se pode notar no texto de Octavio Freitas, datado de 1915 (apud Lopes, 1925a: 163):"Muito embora seja este producto genuinamente nosso, constituindo por si só uma das nossas principaes fontes de riqueza e prosperidade industrial, é preciso combater o alcoolismo por todos os meios, por todos os modos".

A luta antialcoólica encerrava embaraçosa contradição: sendo a luta contra o alcoolismo um dos carros-chefe de ação da LBHM, como resolver o problema da relação com os fabricantes e comerciantes de bebidas alcoólicas? Como colocar o aparato técnico, médico-psicológico, "a serviço do Commercio e da Industria moderna” (como propunha Penafiel, em 1925), nesse terreno específico, sem ferir os princípios eugênico-higienistas? O texto de Ernani Lopes expunha a dificuldade:

Tem a nossa Liga pela nobre classe commercial o mais subido apreço e acatamento. Se divergimos do ponto de vista dos commerciantes de bebidas alcoolicas, nada tem isto que vêr com os outros ramos de negocios não prejudiciaes à saude da collectividade, e reconhecemos, aliás, que os proprios alcoolizadores têm em seu favor a attenuante de já terem vindo encontrar consolidado pelas forças da tradição um estado de coisas na verdade difficilmente modificavel. Não tenho duvida, aliás, no intimo, todos os commerciantes dão razão à nossa campanha, porque sei que os animam os mesmos sentimentos que nos levam a combater os males degeneradores da raça, para beneficiar a nossa pátria. (Lopes, 1929: 15-16)

26 Segundo Luz e colaboradores (1982: 22), "os médicos (...) são, objetiva e historicamente, os primeiros intelectuais orgânicos da ordem burguesa e seus setores dominantes no Brasil”. 
O trecho anterior se refere a uma seção realizada no Conselho Municipal que abordava o problema do alcoolismo e acenava com a expectativa de uma vigorosa "repressão legal do vício, na capital do Brasil" (Lopes, 1929: 13). Nessa seção, um membro do Partido Comunista, Octavio Brandão, fez uma crítica da alienação e assinalou a relação de dependência entre Estado capitalista e indústria do álcool. Ernani Lopes retrucou, deixando bem clara sua opção de classe e motivação econômica:

A proposito, poderiamos perguntar aos communistas como explicam elles que Henry Ford e tantos outros representantes a mais não ser legitimos do capitalismo norte-americano - tão atacado pela communa - sejam os mais ardorosos enthusiastas da lei secca, ${ }^{27}$ cuja excellencia proclamam, justamente por obterem, depois della, melhor e maior producção dos seus operários. (Lopes, 1929: 14-15)

Penafiel, em crítica aos socialistas, dizia ser a questão alcoólica mais moral e biológica do que econômica e exortava:

É preciso contar com os operarios, com os seus agrupamentos mais intelligentes, para que as sociedades de classe, obtendo melhores condições de trabalho, elles proprios segreguem os retardados, os inadaptaveis, os degenerados, o 'residuo' que a lucta pelo progresso vae deixando à margem do caminho (...). É preciso formar, primeiro a alma de uma democracia nova e pura, para a sociedade resolver o problema do alcoolismo. (LBHM, 1925a: 150-151)

É possível perceber que, no caminho da construção de uma sociedade eugênica e higienizada, fundada no valor do trabalho subsumido ao capital, havia obstáculos a opor ética e economia. Para seguir à risca cada passo do processo de higienização da sociedade, mantendo a coerência interna do discurso, o embate com as forças do capital seria uma consequência racional inevitável. Esse confronto, no entanto, nunca se deu na história: atacar um aliado ou tê-lo por inimigo poderia fazer ruir todo o projeto. Mas havia uma espécie de consciência

27 Lei seca era um assunto controverso, mesmo no interior da Liga. Embora houvesse inúmeros defensores, entre os quais Gustavo Riedel e Miguel Couto, havia também os que a questionavam, entre eles Carlos Penafiel, considerando-a "inadaptavel ao meio brasileiro, cujas leis constitucionaes pelo seu espirito liberal a repellem, e prematura de mais para o gráo que attingimos em materia de costumes e habitos" (LBHM, 1925a: 149). 
tranquilizadora a excluir da ampla categoria dos degenerados os representantes do 'capitalismo alcoólico':

Os peritos sabem perfeitamente que entre os industriaes e commerciantes de bebidas alcoolicas existem cidadãos exemplares, a todos os respeitos, não sendo portanto, a estes, que se devem endereçar quaesquer advertencias, tanto mais se trata de industria e commercio lícitos. (LBHM, 1925f: 163)

As campanhas da LBHM prosseguiram com seus discursos monótonos, sem grandes conflitos internos: um brado aqui, outro acolá a favor da lei seca ou do aumento da carga tributária sobre o álcool - debalde - e o investimento constante sobre o alcoólatra (em geral, o trabalhador pobre), considerado um 'degenerado'. De forma enviesada, o discurso utilizado era o de que nem todos os que faziam uso de bebidas alcoólicas deveriam ser estigmatizados pela degeneração racial: haveria a categoria dos "moderados", o que demarcava não um problema estritamente racial, mas, sobretudo, uma distinção de classe social.

Todavia, se depois de análises críticas, o discurso da LBHM parece reacionário e vencido, até mesmo fascista, e se a concretude de suas palavras por vezes parece ter se desmanchado no tempo, talvez não se deva cantar vitória: se não logrou, na história, concretizar o seu projeto de nação higiênica e eugênica, conseguiu fazer vingar na sociedade uma representação médico-moral de alcoolismo e do alcoólatra que, até hoje, vigora em nossas mentes e nos aterroriza com as imagens mais sombrias.

\section{Referências}

\section{Fontes}

ESPOSEL, F. Idéas geraes sobre hygiene mental. Arquivos Brasileiros de Higiene Mental (ABHM), I(1): 101-107, 1925.

FARANI, A. Cirurgia e hygiene mental. Arquivos Brasileiros de Higiene Mental (ABHM), I(2): 37-68, 1925.

FONTENELLE, J. P. Hygiene mental e educação. Arquivos Brasileiros de Higiene Mental (ABHM), I(1): 1-10, 1925.

KEHL, R. A esterilização dos grandes degenerados e criminosos. Arquivos Brasileiros de Higiene Mental (ABHM), I(2): 69-74, 1925. 
KEHL, R. A campanha da eugenia no Brasil. Arquivos Brasileiros de Higiene Mental (ABHM), IV(2): 93-96, 1931.

LEllo Universal. Novo Diccionario Encyclopedico Luso-Brasileiro. Porto: Lello Irmãos, s.d., 1443.

LIGA BRASILEIRA DE HIGIENE MENTAL (LBHM). Contra o alcoolismo: em favor da hygidez mental. Arquivos Brasileiros de Higiene Mental (ABHM), I(1): 147-161, 1925a.

LIGA BRASILEIRA DE HIGIENE MENTAL (LBHM). A contribuição da hygiene mental no $2^{\circ}$ Congresso Brasileiro de Hygiene. Arquivos Brasileiros de Higiene Mental (ABHM), I(1): 193-201, 1925b.

LIGA BRASILEIRA DE HIGIENE MENTAL (LBHM). Actas e trabalhos da LBHM. Arquivos Brasileiros de Higiene Mental (ABHM), I(1):210-213, 1925c.

LIGA BRASILEIRA DE HIGIENE MENTAL (LBHM). Estatutos da Liga Brasileira de Hygiene Mental. Arquivos Brasileiros de Higiene Mental (ABHM), I(1):223-234, 1925d.

LIGA BRASILEIRA DE HIGIENE MENTAL (LBHM). Editorial. Arquivos Brasileiros de Higiene Mental (ABHM), I(1), 1925e.

LIGA BRASILEIRA DE HIGIENE MENTAL (LBHM). Trabalhos da LBHM. Arquivos Brasileiros de Higiene Mental (ABHM), I(2): 151-185, $1925 \mathrm{f}$.

LIGA BRASILEIRA DE HIGIENE MENTAL (LBHM). Editorial. Arquivos Brasileiros de Higiene Mental (ABHM), II(2): 57-60, 1929.

LOPES, E. Bibliographia brasileira do alcoolismo. Arquivos Brasileiros de Higiene Mental (ABHM), I(1): 161-166, 1925a.

LOPES, E. Resenha de "Prophylaxia Mental". Arquivos Brasileiros de Higiene Mental (ABHM), I(1): 167-181, 1925b.

LOPES, E. Trabalhos de anti-alcoolismo. Arquivos Brasileiros de Higiene Mental (ABHM), II(1): 12-16, 1929.

MOREIRA, J. Reformatorios para alcoolistas. Arquivos Brasileiros de Higiene Mental (ABHM), II(2): 61-63, 1929.

PENAFIEL, C. O elemento psychico no trabalho humano: a Liga Brasileira de Hygiene Mental e os novos horizontes da hygiene publica. ABHM, I(2): 11-24, 1925.

ROXO, H. Hygiene mental. Arquivos Brasileiros de Higiene Mental (ABHM), I(2): 1-9, 1925.

\section{Referências}

AlbuQuerque, M. M. Pequena História da Formação Social Brasileira. Rio de Janeiro: Graal, 1986. 
AMARANTE, P. D. Asilos, alienados, alienistas: uma pequena História da Psiquiatria no Brasil. In: AMARANTE, P. (Org.). Psiquiatria Social e Reforma Psiquiátrica. Rio de Janeiro: Editora Fiocruz, 1994.

AndRADE, O. Serafim Ponte Grande. Rio de Janeiro, São Paulo: José Olympio, Civilização Brasileira, Editora Três, 1973.

Carvalho, A. M. T. O Elemento Psychico no Trabalho Humano. A Liga Brasileira de Higiene Mental e o Processo de Produção Discursiva do Campo Trabalho e Higiene Mental no Brasil entre 1925 e 1934, 1997. Dissertação de Mestrado, Rio de Janeiro: Escola Nacional de Saúde Pública Sergio Arouca, Fundação Oswaldo Cruz.

CARVALHO, A. M. T. Trabalho e higiene mental: processo de produção discursiva do campo no Brasil. História, Ciências, Saúde - Manguinhos, VI(1): 133-156, 1999.

CARVAlho, J. M. Os Bestializados: o Rio de Janeiro e a República que não foi. São Paulo: Companhia das Letras, 1996.

COSTA, J. F. História da Psiquiatria no Brasil: um corte ideológico. Rio de Janeiro: Documentário, 1976.

ENGEL, M. G. Fontes para uma História das Concepções acerca da Loucura na Cidade do Rio de Janeiro (1830-1930). Rio de Janeiro: Universidade Federal Fluminense, Conselho Nacional de Desenvolvimento Científico e Tecnológico, 1993. (Relatório de pesquisa)

ENGEL, M. G. A Loucura na Cidade do Rio de Janeiro: ideias e vivências (1830-1939), 1995. Tese de Doutorado, São Paulo: Instituto de Filosofia e Ciências Humanas, Universidade Estadual de Campinas.

FOUCAULT, M. Vigiar e Punir. Petrópolis:Vozes, 1987.

HIRANO, S. Pré-capitalismo e Capitalismo. São Paulo: Hucitec, 1988.

HOLANDA, S. B. Raízes do Brasil. Rio de Janeiro: José Olympio, 1993.

LIMA, H. F. História Político-Econômica e Industrial do Brasil. São Paulo: Companhia Editora Nacional, 1976.

LIMA, N. T. \& HOCHMAN, G. Condenado pela raça, absolvido pela medicina: o Brasil descoberto pelo movimento sanitarista da Primeira República. In: MAIO, M. C. \& SANTOS, R. V. (Orgs.). Raça, Ciência e Sociedade. Rio de Janeiro: Editora Fiocruz, 1996.

LOBO, E. M. L. Rio de Janeiro Operário: natureza do estado, conjuntura econômica, condições de vida e consciência de classe: 1930-1970. Rio de Janeiro: Access, 1992.

LUZ, M. T. et al. Medicina e Ordem Política Brasileira: políticas e instituições de saúde (1850-1930). Rio de Janeiro: Graal, 1982. 
MARX, K. Formações Econômicas Pré-capitalistas. Rio de Janeiro: Paz e Terra, 1986.

PORTOCARRERO, M. Juliano Moreira e a Descontinuidade Histórica da Psiquiatria, 1980. Dissertação de Mestrado, Rio de Janeiro: Pontifícia Universidade Católica do Rio de Janeiro.

REIS, J. R. F. Higiene Mental e Eugenia: o projeto de "Regeneração Nacional" da Liga Brasileira de Higiene Mental (1920-1930), 1994. Tese de Mestrado, São Paulo: Instituto de Filosofia e Ciências Humanas, Universidade Estadual de Campinas.

SCWHARTZ, S. "Fabrico do açúcar". In: SILVA, M. B. N. (Org.). Dicionário da História da Colonização Portuguesa no Brasil. São Paulo:Verbo, 1994.

SILVA, H. 1926: A Grande Marcha. Rio de Janeiro: Civilização Brasileira, 1965.

SOUZA, R. L. Cachaça, vinho, cerveja: da Colônia ao século XX. Estudos Históricos CPDOC/FGV, 33: 1-22, 2004.

WALlerstein, I. Capitalismo Histórico e Civilização Capitalista. Rio de Janeiro: Contraponto, 2001. 


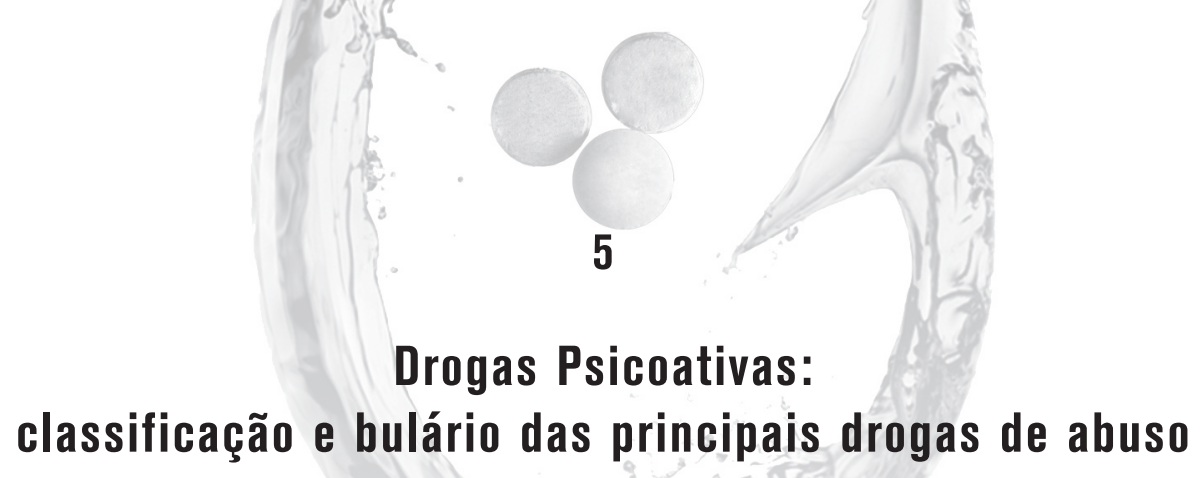

Sergio Alarcon

Há certa controvérsia com relação à origem do termo 'droga'. Considera-se, em geral, que seu significado seja proveniente do holandês medieval droog, que significa seco. O termo parece ter se expandido na época das grandes navegações, cuja hegemonia foi durante muito tempo disputada entre os europeus, com eventual vantagem para os holandeses, graças ao sucesso da Companhia Holandesa das Índias Orientais (VOC - Vereenigde Oost-Indische Compagnie) no monopólio de algumas rotas de mercadorias asiáticas, em especial as chamadas 'folhas secas'. Estas, na verdade, representavam apenas uma parte dessas mercadorias, também denominadas 'especiarias'. Tratavam-se de produtos de origem vegetal, como a canela, o sândalo, a noz moscada, a pimenta, a baunilha, o gengibre, o açafrão, o cânhamo e o ópio, cujo cultivo e/ou extração apenas era possível nos países com climas distintos daqueles encontrados na Europa (Alarcon, 2008).

Autores como Fernand Braudel (1961) ou Antonio Escohotado (2002) revelam uma variação temporal, não tanto da qualidade dos produtos bioquímicos, nem do termo que os designa, mas do significado desse termo. Assim, percebe-se que o significado de 'droga'é historicamente polissêmico, tendo sido utilizado, tanto para aquilo que se ingere como alimento quanto para o que se ingere como não alimento - e, até mesmo, em algum instante, para substâncias absolutamente indigestas. O açúcar, o mate e o chocolate já foram considerados 
drogas, tanto nesse sentido genérico que hoje em dia poderíamos associar ao termo inglês commodities quanto no que também hoje em dia associamos ao 'mal'. O chocolate (que contém uma metilxantina estimulante chamada teobromina), por exemplo, chegou a ser proibido a mulheres e crianças na Espanha da era mercantilista (Carneiro, 2005).

Com o tempo, o significado do termo foi variando levemente, até que, finalmente, na era das ciências positivas, passou-se a designar pelo termo droga todas as substâncias utilizadas em farmácia e com ação farmacológica, ou seja, capazes de, quando introduzidas em um organismo, modificar-lhe as funções.

Aqui, procuraremos registrar e classificar apenas uma pequena porção dessas drogas: as psicoativas, ou seja, aquelas que agem alterando o funcionamento do cérebro. Utilizaremos critérios ligados aos seus principais efeitos, além de oferecermos ao leitor um bulário no qual as principais drogas serão rapidamente apresentadas, enfatizando tanto seus aspectos sedutores quanto seus aspectos venenosos.

\section{Critérios Classificatórios}

As drogas psicotrópicas ou psicoativas podem ser classificadas de diversas formas, segundo diferentes critérios, como, por exemplo, o tipo de alteração farmacológica que efetuam no sistema nervoso central (SNC) e no comportamento do usuário (Quadro 1); a origem, se naturais ou sintéticas (Quadro 2); ou o estatuto jurídico, se lícitas ou ilícitas (Quadro 3). De maneira geral, quando falamos cotidianamente sobre drogas, utilizamos esses critérios associados. Em termos médicos e de assistência, a classificação mais difundida por sua simplicidade e praticidade é aquela estabelecida por Louis Chaloult (1971), que leva em conta o tipo de ação ou efeito farmacológico que as drogas causam no cérebro, dividindo-as em três grupos distintos.

O primeiro grupo reúne as drogas capazes de, primordialmente, diminuir ou deprimir a atividade do cérebro e que por isso são chamadas de drogas depressoras da atividade do SNC. O protótipo desse tipo de droga é o álcool, mas há também o grupo dos soníferos ou hipnóticos, como os barbitúricos (fenobarbital, fenitoína etc.); o grupo dos ansiolíticos, como os benzodiazepínicos (diazepam, bromazepam, lorazepam etc); os opiáceos ou narcóticos, que aliviam a dor e dão sonolência, como a morfina e seus derivados (heroína, codeína, meperidina etc); e os inalantes ou solventes, como colas, tintas e removedores. 
O segundo grupo de drogas psicotrópicas reúne aquelas que atuam aumentando a atividade cerebral, motivo pelo qual recebem a denominação de drogas estimulantes da atividade do SNC. São exemplos de drogas psicotrópicas a cocaína, as anfetaminas e derivados (incluindo alguns anorexígenos usados em fórmulas para emagrecimento como a dietilpropriona e o femproporex) e o tabaco.

O terceiro grupo é constituído por drogas que agem modificando a qualidade do funcionamento cerebral. Por essa razão, são denominadas drogas perturbadoras da atividade do SNC. Representam esse grupo as drogas chamadas alucinógenas, como a mescalina (do cacto mexicano), a maconha ou THC (tetrahidrocanabinol), a psilocibina (cogumelos), o lírio (trombeteira, zabumba ou saia branca), o LSD, o ecstasy e os anticolinérgicos.

Quadro 1 - Classificação de acordo com os efeitos farmacológicos no SNC

1. Depressoras da Atividade do SNC ou Psicolépticos: álcool; soníferos ou hipnóticos; ansiolíticos; opiáceos; inalantes ou solventes.

2. Estimulantes da Atividade do SNC ou Psicoanalépticos: cocaína (e seus derivados como crack e merla); anfetaminas; tabaco.

3. Perturbadoras da Atividade do SNC, Alucinógenas ou Psicodislépticas: mescalina (do cacto mexicano); maconha ou THC (tetrahidrocanabinol); psilocibina (cogumelos); lírio (trombeteira, zabumba ou saia branca); LSD; MDMA (ecstasy); anticolinérgicos.

Quadro 2 - Classificação segundo a origem

\begin{tabular}{|l|l|l|l|}
\hline Drogas & Depressoras & Estimulantes & Perturbadoras \\
\hline \multirow{2}{*}{ Naturais } & $\begin{array}{l}\bullet \text { Álcool } \\
\bullet \text { Opiáceos }\end{array}$ & $\begin{array}{l}\bullet \text { Cocaína } \\
\bullet \text { Cafeína } \\
\text { - Nicotina }\end{array}$ & $\begin{array}{l}\text { - Maconha } \\
\text { Ayahuasca }\end{array}$ \\
\hline \multirow{2}{*}{ Sintéticas } & $\begin{array}{l}\text { - Ansiolíticos/Sedativos } \\
\bullet \text { Inalantes }\end{array}$ & $\bullet$ Anfetaminas & $\bullet$ \\
\hline
\end{tabular}

Quadro 3-Classificação segundo o estatuto jurídico

\begin{tabular}{|c|c|}
\hline Lícitas & Ilícitas \\
\hline Álcool & Cocaína \\
Tabaco & Maconha \\
Cafeína & LSD \\
Solventes & MDMA (Ecstasy) \\
& Heroína \\
\hline
\end{tabular}




\section{Bulário das Principais Drogas de Uso e Abuso}

\section{Álcool}

O álcool é consumido no Brasil desde antes da colonização europeia. É imemorial o costume tupinambá de produzir o cauim, nome de uma bebida fermentada feita através da mastigação e salivação da mandioca. Além da mandioca, o cauim também podia ser preparado com frutas como o caju, o abacaxi, a jabuticaba etc. Em geral, apenas as mulheres jovens e consideradas bonitas podiam prepará-lo, mascando a raiz ou a fruta e misturando-lhe a saliva para provocar a fermentação. Sua utilização era destinada a rituais e festas, segundo regras determinadas pela cultura indígena, como nas comemorações pelo nascimento de uma criança, nos rituais de 'maioridade' ou em orgias canibalescas.

O tipo de álcool presente nas bebidas como o cauim, a cachaça, a cerveja ou o vinho é próprio para o consumo humano: o álcool etílico. Trata-se de uma substância química produzida mediante a fermentação do açúcar encontrado em vários produtos de origem vegetal (cana-de-açúcar, frutas, arroz, mandioca etc.). Essa fermentação é realizada por fungos unicelulares (leveduras - Figura 1) que, ao se alimentarem desses produtos, não realizam a digestão completa como a que é feita por animais superiores (mamíferos, aves e répteis). A digestão incompleta dos açúcares gera como sobra o álcool etílico, que é então excretado no meio ambiente.

Figura 1 - Estruturas da levedura Saccharomyces cerevisiae responsável pela produção da cerveja

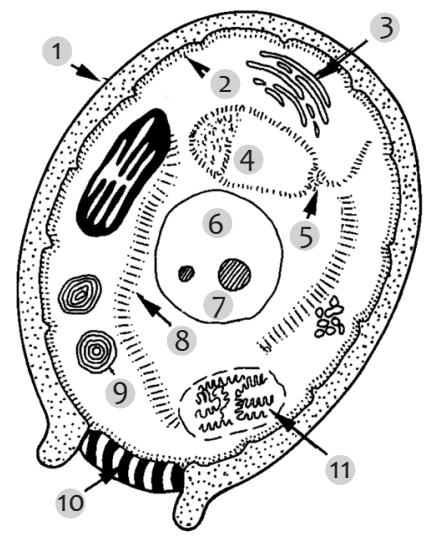

1. Parede

2. Membrana

3. Aparelho de Golgi

4. Núcleo

5. Centríolo

6. Vacúolo

7. Polifosfato

8. Retículo endoplasmático

9. Liposomo

10. Cicatriz de brotamento

11. Mitocôndrias 
Sabe-se, hoje em dia, que a ingestão de álcool em doses baixas diminui o risco de doenças cardiovasculares. Alguns autores acreditam que os limites de um beber seguro podem ser mensurados levando-se em conta uma série de fatores, como as relações entre quantidade e tempo, associadas às características biológicas encontradas nas diferenças entre os gêneros, os biótipos etc.

Para ajudar na determinação aproximada para um beber seguro, criou-se o conceito de unidade de álcool. Uma unidade de álcool significa a ingestão de mais ou menos 10 gramas de álcool puro e varia em cada tipo de bebida. Assim, uma unidade de álcool é o que se encontra aproximadamente em um copo de cerveja de $250 \mathrm{ml}$, ou em uma taça de vinho de $90 \mathrm{ml}$, ou em uma dose de destilado de $25 \mathrm{ml}$. Como a capacidade média do corpo para metabolizar o álcool é de $25 \mathrm{ml}$ a $40 \%$ por hora, para um beber seguro recomenda-se, em primeiro lugar, manter uma quantidade de ingestão entre sete e 14 unidades semanais para as mulheres e entre 14 e 21 unidades semanais para os homens; em segundo lugar, recomenda-se não exceder esses valores em uma unidade de tempo muito pequena, ou seja, não consumir toda essa quantidade, por exemplo, em um único dia (Quadro 4).

Quadro 4 - Relação aproximada de ingestão alcoólica/quantidade/tempo para o beber seguro

\begin{tabular}{|l|l|}
\hline HOMENS & $\begin{array}{l}\text { Beber seguro = ingestão de até } 21 \text { unidades de álcool em sete dias (em } \\
\text { média seriam três copos de } 250 \mathrm{ml} \text { de cerveja/dia, ou três taças de } 90 \mathrm{ml} \\
\text { de vinho/dia ou três doses de } 25 \mathrm{ml} \text { de destilados/dia). }\end{array}$ \\
\hline MULHERES & $\begin{array}{l}\text { Beber seguro = ingestão de até } 14 \text { unidades de álcool em sete dias (em } \\
\text { média seriam menos de dois copos de } 250 \mathrm{ml} \text { de cerveja/dia, ou menos } \\
\text { de duas taças de } 90 \mathrm{ml} \text { de vinho/dia ou menos de duas doses de } 25 \mathrm{ml} \text { de } \\
\text { destilados/dia). }\end{array}$ \\
\hline
\end{tabular}

A metabolização de padrões de consumo maiores que os citados não é tarefa fácil para o organismo humano. Esse fator, associado à própria capacidade de agressão do álcool às células do corpo, produzirá as doenças e os distúrbios relacionados ao uso nocivo e à dependência.

O álcool etílico guarda em si um alto poder calórico, mas um baixo valor nutritivo. Dependendo da quantidade de álcool ingerido, o organismo humano terá que se desdobrar para transformar essa substância em algo útil para o corpo. Cerca de $90 \%$ do álcool absorvido é metabolizado no fígado, os outros $10 \%$ 
são eliminados de forma inalterada pelos pulmões e rins. As enzimas hepáticas responsáveis pela metabolização do álcool são a álcool desidrogenase (ADH) e a aldeído desidrogenase (ALDH). Se, por uma característica individual, determinada pessoa tem menos ADH que o normal em seu fígado, será formado em maior quantidade um composto chamado acetoaldeído, que é um produto tóxico. O fígado das mulheres, em geral, tem essa característica, o que faz com que se intoxiquem mais facilmente com o álcool do que os homens.

Pessoas habituadas a uma ingestão elevada de álcool adquirem a capacidade de metabolizá-lo com mais rapidez, ou seja, os efeitos da intoxicação alcoólica demoram mais tempo para aparecer, fazendo com que o usuário gradativamente vá aumentando a quantidade ingerida para produzir o efeito desejado. A isso se dá o nome de 'tolerância'.

Como o álcool é uma substância solúvel em água, com grande poder de difusão pelo organismo, todos os órgãos do corpo, sem exceção, podem ser afetados pelo seu uso. Ao ser absorvido pelo estômago e pelos intestinos, o álcool penetra na circulação sanguínea e daí é distribuído para todas as células, ainda que algumas sejam mais afetadas por seus efeitos do que outras. As células mais afetadas estão no fígado, no pâncreas, nas glândulas em geral, no coração e vasos sanguíneos e no tubo digestivo.

Na prática, comumente é no fígado que se observam as primeiras manifestações deletérias do uso desregrado e crônico do álcool. Quando a corrente sanguínea faz chegar a esse órgão álcool de forma contínua e em quantidade acima de sua capacidade de metabolização, inicia-se uma série de eventos visando à conversão da substância em algo útil - que acabam por lesionar as células hepáticas. Sobre essas lesões, verifica-se, primeiramente, um fenômeno conhecido como esteatose hepática, ou seja, o acúmulo anormal de gordura entre as células do fígado. Essa gordura acumulada representa, tão somente, a incapacidade do organismo em 'digerir' todo o álcool ingerido. A gordura acumulada por entre as células hepáticas, com o tempo, pode iniciar um processo de morte celular e consequente fibrose, ou seja, a formação de cicatriz. Esse processo é conhecido como cirrose hepática. ${ }^{1} \mathrm{O}$ fígado torna-se rígido (cirrose é uma palavra derivada do termo grego kýrrhos, 'pedaço de pedra') em virtude da extensão da fibrose. Em decorrência da cirrose, o sangue encontra dificuldades para percorrer o fígado em direção aos pulmões, e essa alteração secundária

1 Sabe-se, hoje em dia, que não é entre os alcoolistas, mas entre as pessoas portadoras de hepatite $\mathrm{C}$, que se encontra a maior incidência de cirrose hepática. 
no fluxo normal do sangue vai comprometer as veias do estômago e do esôfago (parte do tubo digestivo que vai da boca ao estômago), produzindo verdadeiras varizes, que são, normalmente, a causa dos sangramentos digestivos que os grandes consumidores de álcool manifestam. Esses usuários, por apresentarem alterações na função normal do fígado, têm menos fatores de coagulação (que são substâncias também produzidas pelo fígado), o que acaba por facilitar a manutenção desses sangramentos, podendo levar à morte por choque hipovolêmico, isto é, pela diminuição do volume de sangue no corpo.

O fígado é uma verdadeira fábrica de substâncias a serviço do organismo. Hormônios, vitaminas, proteínas, fatores de coagulação sanguínea e substâncias imunologicamente ativas são reduzidas nesse importante órgão. Da mesma maneira, substâncias inúteis ao organismo são, no fígado, inativadas e transformadas em compostos inofensivos ou, até mesmo, convertidas em novas substâncias, agora úteis ao metabolismo normal. A falência desse órgão significa a morte de todo o organismo.

Com relação aos efeitos no sistema cardiovascular, como já salientado, o consumo de álcool (especialmente os vinhos tintos, que possuem uma substância antioxidante e adstringente chamada tanino) ${ }^{2}$ parece diminuir os riscos de aparecimento de doenças. No entanto, quando da existência de um uso abusivo cronificado, verifica-se o risco aumentado de hipertensão arterial, arteriosclerose, infarto do miocárdio e derrames cerebrais. Também pode ocorrer o surgimento de miocardiopatia, que é uma doença na qual a função do coração fica comprometida, havendo dilatação das cavidades cardíacas e diminuição no bombeamento do sangue.

Os efeitos do uso desmedido de álcool no pâncreas, por sua vez, incidem sobre a digestão e desregulam o controle das taxas do açúcar no sangue, podendo mesmo levar ao diabetes, visto que cabe ao pâncreas organizar essas duas funções. Uma condição aguda, conhecida como pancreatite, ou seja, a inflamação do pâncreas, causa insuficiência pancreática aguda, que é grave e potencialmente fatal.

Também o sistema imunológico pode ser afetado pelo uso frequentemente imoderado do álcool. Com isso, um fenômeno natural conhecido como vigilância imunológica, ou seja, o estado de constante alerta que o sistema imunológico manifesta contra a invasão de micro-organismos produtores de infecção

\footnotetext{
2 Substância extraída da casca e das sementes das uvas e também da casca do carvalho com que são feitos os tonéis utilizados para a maturação da bebida.
} 
e contra perigos surgidos dentro do próprio organismo (como, por exemplo, células capazes de produzir câncer) fica comprometido. A ingestão constante e abusiva do álcool aumenta estatisticamente a incidência de câncer de boca, esôfago, garganta, estômago e intestino. É importante salientar que o câncer de fígado, conhecido como hepatocarcinoma, tem incidência aumentada nos indivíduos que ingerem álcool de forma crônica e imoderada.

No cérebro, o álcool não age sobre um ou outro receptor molecular específico, como ocorre com a maioria das outras substâncias psicoativas. Tendo a capacidade de se difundir nos líquidos orgânicos (como já mencionado anteriormente, por ser solúvel em água, e a água ser o constituinte principal do organismo humano), acaba por interferir em todas as interações químicas dos neurônios, que são as principais células do sistema nervoso. Com isso, o pensamento, a capacidade cognitiva (de aprendizado) e as ordens que o cérebro envia para os músculos ficarão drasticamente afetados. Em especial, pode ocorrer uma encefalite (inflamação do encéfalo) em virtude da carência nutricional crônica de vitamina B1, já que a ingestão de bebidas alcoólicas reduz a absorção intestinal da vitamina ao mesmo tempo que aumenta a excreção renal de magnésio. Como a vitamina B1 e o magnésio são indispensáveis para o metabolismo das células do cérebro, sua redução ou ausência altera a capacidade das células de absorverem os nutrientes, o que causa sua morte. Trata-se de uma grave disfunção cerebral caracterizada pelo aparecimento abrupto de oftalmoplegia, ataxia e confusão mental (situação conhecida como encefalopatia de Wernicke). Quando esses sinais e sintomas vêm acompanhados por amnésia retrógrada e anterógrada, tem-se a chamada síndrome de Wernicke-Korsakoff. O tratamento dessa encefalite requer a abstinência total do álcool e a administração intramuscular de tiamina. O prognóstico é ruim, com cerca de 80\% dos casos evoluindo para um quadro irreversível de demência.

O sono e o comportamento podem ser também francamente alterados pelo uso abusivo do álcool. O efeito depressor produzido é inicialmente muito semelhante ao dos barbitúricos e benzodiazepínicos (compostos químicos sintéticos indutores de sono). Por isso, é senso comum pensar que o álcool ajuda e melhora o ciclo sono-vigília. Porém, na verdade, as fases 'repousantes' do sono diminuem, e o indivíduo tende a acordar cansado.

A gestante que costuma usar álcool pode ter abortamento, e o feto pode apresentar lesões orgânicas e neurológicas. As crianças podem nascer com um conjunto de sinais e sintomas denominado Síndrome Alcoólica Fetal (SAF), que é reconhecida como a maior causa de retardo mental no Ocidente. Essa 
síndrome é caracterizada por déficit de crescimento, dismorfismo facial (que pode se evidenciar por microcefalia, micro-oftalmia e/ou fissura palpebral pequena, filtro nasal hipoplásico com lábio superior fino e hipoplasia de maxilar), além de anormalidades no desenvolvimento do SNC.

De todas as drogas, o álcool é a única que possui uma bem demonstrada relação causa-efeito com práticas de violência (Chermack et al., 2000), em particular, a violência doméstica, tanto física quanto psicológica, tanto contra mulheres quanto contra homens - embora os homens sejam os principais agressores e as mulheres as principais vítimas (Moreira, 2008).

Por fim, conhecendo-se os mecanismos pelos quais o álcool produz seus efeitos prazerosos, assim como os diversos tipos de danos que o seu uso pode acarretar, pode-se prescrever ações educativas para a prevenção de problemas, tais como ingestão, concomitante ao álcool, de água e líquidos não alcoólicos, e, no caso de uso crônico, de vitaminas do complexo B, especialmente a tiamina (vitamina B1) - o que, apesar de importante, não substitui, obviamente, uma nutrição adequada. Em especial, recomenda-se manter a utilização do álcool limitada à possibilidade de se contar com a companhia de alguém sóbrio, que possa ajudar no caso de qualquer eventualidade.

\section{Tabaco}

O tabaco é, provavelmente, a droga de consumo mais disseminada no mundo contemporâneo. Considera-se, hoje em dia, que pelo menos um terço da população mundial é tabagista. Embora os efeitos da dependência que a nicotina exerça já fossem conhecidos há algumas décadas, só no final da década de 1980 é que foram reunidas, cientificamente, evidências inquestionáveis sobre como a nicotina, além de causar dependência, produz danos irreversíveis à saúde. Segundo a Organização Mundial da Saúde (OMS), o tabaco seria o responsável por cerca de cinco milhões de mortes por ano em todo o mundo, o que faz dessa droga a maior causadora de óbitos dentre todas as drogas, lícitas ou ilícitas (Carneiro, 2005).

A nicotina, um dos milhares de compostos químicos contidos nos cigarros, é sua principal substância psicoativa e a que provoca a dependência. Mas além da nicotina, muitas dessas substâncias liberadas pela queima do cigarro têm a capacidade de produzir uma série de lesões no organismo, que ocorrem especialmente nos pulmões, manifestando-se sob a forma de bronquite, asma, infecções de repetição e câncer. 
A relação entre o câncer e o cigarro é bem conhecida e não se restringe ao câncer de pulmão. As lesões podem ser encontradas em praticamente todos os órgãos do corpo humano. No início, não são lesões macroscópicas, ou seja, só podem ser observadas com o auxílio do microscópio. Aparecem, normalmente, em decorrência de lesões isoladas na microcirculação sanguínea, nos capilares, que são os vasos sanguíneos menores, aqueles que ao entrarem em contato com as células individualmente levam-lhes os nutrientes necessários e delas recolhem os produtos (o lixo biológico) que o corpo não utilizará mais. Quando as toxinas liberadas pelo cigarro passam para o pulmão e ganham a corrente sanguínea, ao chegarem nos capilares, acabam impedindo as trocas normais entre estes e as células. Com isso, acumulam-se no organismo os chamados radicais livres, responsáveis, com o passar dos anos, pela produção de lesões, que progressivamente tornam-se maiores.

Sobre o uso do tabaco na gestação, é reconhecido que os filhos de mães tabagistas apresentam menor peso ao nascerem. Além disso, o uso do tabaco durante a gravidez é responsável por um aumento da mortalidade fetal e neonatal, maior frequência de abortos espontâneos e malformações fetais.

É importante salientar o sucesso com que a contrapropaganda e a legislação, aglutinadas à construção social de uma cultura de uso consequente, têm feito retroceder, no Brasil, os malefícios citados.

\section{Anfetaminas}

Pode-se dizer que o principal risco do mau uso das anfetaminas esteja diretamente relacionado com a obsessão pelo emagrecimento que afeta algumas sociedades. Em virtude da disseminação de uma cultura que associa simbolicamente a lipofobia e a androgenia, ocorreu a estimulação e o culto de tipos físicos exageradamente magros, que se tornaram o padrão de beleza imposto para todos, mas, em especial, para as mulheres, que assumiram o lugar de principais vítimas das doenças da beleza.

Enquanto a magreza, para o homem, em geral faz realçar seus caracteres físicos percebidos em nossa sociedade como típicos da masculinidade (quadril estreito em relação aos ombros, realce da musculatura de membros e tórax etc.), nas mulheres, ao inverso, há supressão do fenótipo típico feminino, determinado geneticamente pelo depósito natural de gorduras na região dos seios, quadris e coxas. Claro que não se quer dizer aqui que haja uma maneira, em princípio, certa ou errada, determinada pela natureza biológica ou fisiológica, 
de ser homem ou mulher. No entanto, as construções sociais dos atributos que farão a feminilidade ou a masculinidade de um corpo podem denotar determinadas formas de opressão, de aprisionamento do corpo e da alma, como a associação da beleza à magreza e desta a estereótipos morais, que de imediato interpretam como imoral o inverso. Por isso, torna-se desejável um padrão físico 'androfílico' em detrimento de outro, 'ginecofílico', como sintoma da dominação de um gênero sobre o outro, de tal maneira que prevalece a ideia de um tipo de 'feminilidade' cujas práticas corporais andrógenas discriminam perspectivas diferenciais de se vivenciar o feminino. Como resultado do culto à magreza exagerada, ${ }^{3}$ disseminou-se a ideia de que sob o aspecto andrógeno e, de certa forma, subdesenvolvido para os caracteres sexuais secundários (mantendo a mulher adulta ainda com um aspecto pré-púbere - daí também o sucesso das 'ninfetas' ou 'Lolitas'), ${ }^{4}$ residia não apenas a beleza, como também a saúde da mulher 'senhora de si', moderna, independente do homem etc. Essa crença se fez de tal forma bem articulada que foi percebida por boa parcela da população em geral como parte da própria natureza da mulher, de maneira que cada uma, se confrontada com os motivos de sua intenção em 'emagrecer', podia afirmar sem pudores estar tratando de seu 'bem-estar', conjugando nessa crença as ideias de independência, beleza e saúde. Com o propósito de manter o feminino caracterizado não simplesmente pelo fenótipo, mas principalmente por suas roupas e tinturas, a ditadura da aparência esguia, artificial em seu exagero, colocou as mulheres por décadas à mercê das anfetaminas, produzindo uma legião de anoréxicas e bulímicas pelo mundo afora, sob os auspícios dos costumes, da moda e da própria medicina, esta última supostamente a guardiã da relação ideal entre benefício e dano na relação de um fármaco e um indivíduo.

No Brasil, país onde uma ancestral miscigenação racial inventou corpos com formas acentuadamente curvilíneas e cores diferenciais, as mulheres tornaram-se as maiores vítimas do totalitarismo da magreza. Ainda hoje, quando

\footnotetext{
3 Moda em certa época associada ao aspecto 'cadavérico' dos viciados em heroína, sendo, a partir daí, chamada também de heroin chic, e cujo principal 'modelo' foram as modelos profissionais, como Kate Moss.

4 Lolita é o título do famoso romance do escritor russo Vladimir Nobokov. Deu origem a duas gírias (ninfeta e Lolita) utilizadas para caracterizar, sob o ponto de vista da pedofilia, o corpo de meninas pré-púberes. Daí, podermos acrescentar, também, a pedofilia (apesar da paradoxal repulsa que a sociedade demonstra nos casos literais) como mais um termo (junto com a androfilia e a lipofobia, já citados) da determinação cultural para a produção de corpos femininos exageradamente magros.
} 
o padrão de beleza no mundo tende a migrar do simples corpo seco para a robustez dos músculos hipertrofiados (dando sobrevida à androgenia dominante), o horror feminino ao corpo curvilíneo (curvas mais acentuadas, em geral, no caso das brasileiras) derivou em uma epidemia anfetamínica sem precedentes.

Segundo o relatório anual da Junta Internacional de Fiscalização de Entorpecentes (Jife), braço independente do Escritório das Nações Unidas contra Drogas e Crime, divulgado em 1ำ de março de 2007, a taxa de consumo per capita de anfetaminas no Brasil era, na época, 39,2\% superior à dos Estados Unidos da América (EUA): 12,5 por mil habitantes, entre os brasileiros, contra 4,9 dos americanos (Jife, 2006). Como resposta, a Resolução da Agência Nacional de Vigilância Sanitária (Anvisa), publicada no Diário Oficial da União de 10 de outubro de 2011, veda no Brasil a importação, exportação, fabricação, comércio, distribuição, prescrição de remédios que contenham as substâncias anfepramona, femproporex e mazindol. O Quadro 5 apresenta as principais anfetaminas de uso médico e não médico até 10 de outubro de 2011.

Quadro 5 - Anfetaminas de uso médico e não médico

\begin{tabular}{|l|l|}
\hline \multicolumn{1}{|c|}{$\begin{array}{c}\text { Uso médico } \\
\text { (anorexígeno, anti-TDAH) }\end{array}$} & \multicolumn{1}{c|}{\begin{tabular}{c}
\multicolumn{1}{c|}{ Uso não médico } \\
(recreativo, desempenho)
\end{tabular}} \\
\hline $\begin{array}{l}\text { Fenproporex (Desobesi }{ }^{\circledR} \text { ) } \\
\text { Dietilpropiona (Dualib }{ }^{\circledR} \text { ) }\end{array}$ & $\begin{array}{l}3,4 \text { metilenedioximetanfetamina (MDMA - ecstasy) } \\
\text { Metanfetamina (ice) }\end{array}$ \\
Metifenidato (Ritalina $\left.{ }^{\circledR}\right)$ & Derivado metanafetamínico (crystal) \\
\hline
\end{tabular}

As anfetaminas são drogas euforizantes, derivadas da efedrina, da classe das feniletilaminas, sintetizadas pela primeira vez em 1887 na Alemanha. Inicialmente, foram usadas no tratamento de doenças pulmonares obstrutivo-crônicas, como a asma. Apenas décadas mais tarde, perceberam-se suas propriedades psicoestimulantes e anoréxicas, semelhantes àquelas proporcionadas pela cocaína. Agem no SNC, induzindo a liberação de dopamina e noradrenalina, responsáveis por efeitos sobre o humor. Enquanto os níveis desses neurotransmissores se mantêm altos, a sensação é de euforia, atenção redobrada, autoconfiança e diminuição do apetite (anorexia); quando os neurotransmissores são reabsorvidos (mais ou menos oito horas após o uso em dose baixa/moderada), a sensação é de cansaço e leve depressão. 
Cristais de metanfetaminas, como o ice ou o crystal (incomuns no Brasil), são geralmente fumados em cachimbos de vidro (mas podem também ser injetados ou inalados). O efeito é prolongado (dependendo da quantidade, em torno de 24 horas), e os sintomas euforizantes e estimulantes são intensos.

O fator de tolerância às anfetaminas é excepcionalmente alto. A insensibilização para os efeitos euforizantes pode durar em média três ou quatro dias após o uso da dose prescrita para o efeito anorexígeno. $\mathrm{O}$ uso abusivo provocado pela tolerância produz efeitos deletérios que culminam na chamada psicose tóxica anfetamínica, caracterizada por hiperexcitabilidade e sintomas delirantes e alucinatórios. Já a cessação repentina do uso regular provoca intensa depressão, proporcional à quantidade utilizada, e é caracterizada por letargia, fadiga, insônia ou hipersonia, baixa energia, baixa autoestima, podendo ocorrer até ideação suicida.

Os efeitos orgânicos do uso crônico são severos e perigosos, similares (embora mais graves) aos provocados pela cocaína quando usada em doses análogas. Incluem lesões, que podem ser irreversíveis, em receptores dopaminérgicos e/ou serotoninérgicos, induzindo quadros psicóticos permanentes, com paranoia e heteroagressividade, e também lesões em órgãos como os rins, fígado e coração, produzindo, por exemplo, miocardite ou aumento da pressão arterial. Assim como no caso da cocaína, o uso crônico das anfetaminas pode produzir arritmias e morte súbita por colapso cardiovascular.

\section{Benzodiazepínicos}

Os benzodiazepínicos são uma variante dos remédios conhecidos na medicina como tranquilizantes menores (os tranquilizantes maiores são os neurolépticos, muito utilizados no controle de eventos psicóticos). São indicados para minimizar os efeitos de formas de conduta e pensamento cuja qualidade essencial possa ser categorizada como 'neurótica'. Admitindo que seja a ansiedade, por sua vez, o denominador comum do ânimo neurótico (Escohotado, 2002), essas drogas são preferencialmente utilizadas visando ao efeito ansiolítico. São eficazes também como hipnoindutores (indutores do sono), anticonvulsivantes, miorrelaxantes (relaxam a musculatura) e pré-anestésicos.

O primeiro benzodiazepínico foi o clordiazepóxido, desenvolvido em 1959, e, logo depois, foi sintetizado o diazepam. Atualmente, pode-se encontrar no mercado mais de trinta tipos diferentes dessa classe de drogas. Tornaram-se os mais populares tranquilizantes e soníferos da atualidade, sendo que a quantidade 
anual de suas prescrições corresponde a aproximadamente metade de todos os psicofármacos utilizados no planeta.

Embora os diversos fabricantes e seus aliados resistam a admitir a capacidade aditiva dos benzodiazepínicos, seu uso abusivo é comum, sendo a quarta causa de farmacodependência no Brasil (Carlini et al., 2001). A maneira como o uso abusivo e a dependência se instalam acontece pela conjugação de alguns motivos ainda obscuros, na medida em que é um remédio acessível apenas sob prescrição médica, sendo as hipóteses mais prováveis as que se relacionam com uma medicalização indevida, que ocorre mediante a crença, tanto de prescritores (não tão bem preparados) quanto dos usuários, de que é possível, com o uso, obter-se um efeito preventivo sobre a ansiedade cotidiana e a efetiva existência de um sofrimento cotidiano crônico e insuportável, amiúde em grandes centros urbanos, especialmente nas favelas e periferias, onde a guerra (às drogas e/ou a simples 'guerra' pela sobrevivência) acontece na sua forma mais dramática e cruel.

No caso de dependência, a interrupção do uso deve ser lenta e progressiva. No entanto, a abstinência pode causar efeitos desagradáveis variados, que alguns autores relatam serem mais intensos que os da heroína (Quadro 6), tais como ansiedade de rebote, ataxia, tremores, hipertensão sistólica, sudorese, desconforto epigástrico, irritabilidade, delirium e convulsões tônico-clônicas (como as epiléticas). As principais diferenças entre os diversos benzodizepínicos se dão tanto pelo tempo de meia-vida, ou seja, o tempo que a droga leva para ser eliminada pelo organismo (sendo o tempo de duração do efeito diretamente proporcional ao maior tempo da meia-vida), quanto pela potência.

Quadro 6 - Sinais e sintomas da síndrome de abstinência por BDZ

\begin{tabular}{|l|l|}
\hline Físicos & Psíquicos \\
\hline Dores musculares & Disforia \\
Cefaleia & Irritabilidade \\
Sudorese & Inquietação \\
Tremores & Pesadelos \\
Palpitações & Perda de memória \\
Náuseas & Insônia \\
Vômitos & Dificuldade de concentração \\
Convulsões & Delirium \\
\hline
\end{tabular}


Os quadros mais graves de abstinência são observados com benzodiazepínicos cuja meia-vida é de curta duração, como o clonazepam, o alprazolam ou o lorazepam. Quanto aos de longa duração, um cuidado especial deve ser observado durante o primeiro trimestre de gravidez, já que os benzodiazepínicos podem produzir má-formação fetal, mesmo quando retirados antes da concepção, em virtude da sua capacidade de se manter em altas concentrações plasmáticas por um tempo relativamente longo (Quadro 7).

Quadro 7 - Benzodiazepínicos e respectivas meias-vidas

\begin{tabular}{|c|c|}
\hline $\begin{array}{l}\text { MEIA-VIDA DE CURTA E MÉDIA DURAÇÃO } \\
(\mathrm{T} / 2<30 \text { horas) }\end{array}$ & $\begin{array}{l}\text { MEIA-VIDA DE LONGA DURAÇÃO } \\
(\mathrm{T} / 2=30-100 \text { horas })\end{array}$ \\
\hline 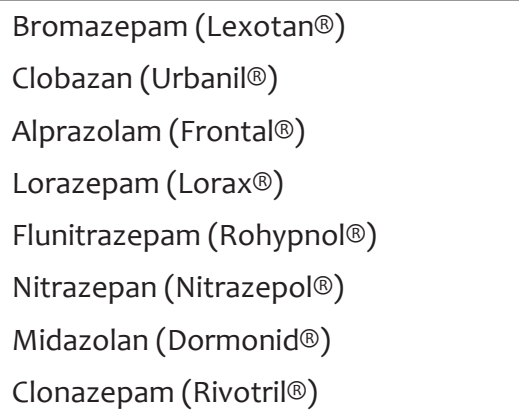 & $\begin{array}{l}\text { Diazepam (Valium }{ }^{\circledR}, \text { Dienpax }^{\circledR} \text { ) } \\
\text { Clordiazepóxido (Psicosedin }{ }^{\circledR} \text { ) } \\
\text { Clorazepato (Tranxilene }{ }^{\circledR} \text { ) } \\
\text { Flurazepam (Dalmadorm }{ }^{\circledR} \text { ) }\end{array}$ \\
\hline
\end{tabular}

\section{Maconha}

Pode-se considerar a planta do gênero Cannabis como uma das mais importantes para os homens de quase todas as culturas, épocas e civilizações. Graças à Cannabis sativa (cânhamo), por exemplo, os europeus do século XIV puderam realizar as chamadas 'grandes navegações'. Isso porque a fabricação dos cabos e velas apropriados às viagens marítimas de longa duração foi possível apenas pela utilização das fibras dessa planta. Antes da fibra de cânhamo, nenhum material havia suportado, pelo tempo necessário à maioria das viagens intercontinentais, a ação corrosiva da maresia. Não seria, portanto, exagero debitar na conta da Cannabis a 'descoberta' do Brasil.

A Cannabis não era utilizada apenas pela área naval. Suas sementes produziam óleo para alimentação e iluminação pública, além de tintas e vernizes. Na medicina, era usada para aliviar dores, e suas folhas e flores eram fumadas com objetivos religiosos e recreativos. Do seu caule fabricava-se papel de qualidade superior, cuja durabilidade era cerca de cem vezes maior do que o papel derivado de outros produtos. 
Atualmente, a política proibicionista que pesa sobre algumas drogas psicoativas, patrocinada pelos EUA e a ONU, incluiu a Cannabis entre os produtos tornados ilegais para o comércio mundial, fato este que fez com que o seu secular uso benéfico para a humanidade fosse não apenas obscurecido mas também invertido.

Existem três espécies de Cannabis: sativa, indica e ruderalis. As três espécies possuem o princípio ativo THC (tetrahidrocanabinol), responsável pelos seus efeitos farmacológicos. O THC advêm de dois produtos para o uso recreativo: um extraído de sua folha, chamado marijuana ou maconha (com cerca de $5 \%$ de concentração de THC) e outro retirado de sua resina, também conhecido como haxixe (em torno de 30\% de concentração de THC).

Os EUA são o principal produtor mundial e também o primeiro mercado consumidor dos derivados psicoativos da Cannabis. Apenas na Califórnia, principal produtor, e onde o consumo e o cultivo da erva para fins terapêuticos está legalizado, o valor comercial das plantações chegou a US\$ 6,7 bilhões em 2006. Esse valor é três vezes superior às estimativas de arrecadação, no mesmo período, do narcotráfico colombiano (Gettman, 2007).

Em termos biológicos, o gosto disseminado pelos efeitos psicoativos do THC explica-se, em parte, pela existência, nos seres humanos, de receptores cerebrais para substâncias endógenas análogas, chamadas endocanabinoides. Aparentemente, a função dos endocanabinoides é relaxante, sendo por isso considerados protetores contra os efeitos danosos de uma excessiva exposição ao estresse. Ao se ligar a esses receptores, o THC ativa o sistema de recompensa cerebral, produzindo sensação de bem-estar e felicidade, seguido de relaxamento e sedação. Quando os usuários se encontram em grupo, ocorrem risos espontâneos, e a sedação é menos acentuada. Essa capacidade de motivar e de transformar positivamente os encontros sociais pode ser considerada a principal característica do prazer associado à droga.

O fato de haver endocanabinoides, ou seja, o fato de o organismo utilizar substâncias análogas ao THC (já foram descobertos quatro canabinoides endógenos) para a autorregulação de várias funções físicas e psíquicas faz supor, evidentemente, que o THC também pode ser usado como medicamento. Um estudo publicado na revista Archives of General Psychiatry (Watson, Benson \& Joy, 2000) mostra pesquisas em andamento para o uso de THC no tratamento de quadros de desnutrição; no controle de espasmos musculares em casos de traumatismo raquimedular; no controle de movimentos desordenados causados por parkisonismo; no controle de crises convulsivas na epilepsia; no tratamento do 
glaucoma etc. Em alguns países, a Cannabis já é utilizada como medicamento. É o caso, por exemplo, do Canadá e da Holanda. Os canadenses foram os pioneiros a reintroduzir a Cannabis como medicamento, e os médicos holandeses desde 2003 receitam THC para pacientes portadores de artrite, esclerose múltipla, síndrome de Gilles de la Tourette, dor crônica, náuseas decorrentes de quimioterapia, distúrbios alimentares (anorexia) etc.

No Brasil a maconha ainda não é um medicamento, mas um produto ilegal, contrabandeado, cuja qualidade é suspeita, podendo produzir, por isso, mais prejuízos ao usuário crônico do que benefícios. Além disso, alguns estudos indicam que é a própria ilegalidade o principal vetor do mau uso do THC, que pode induzir, entre outros problemas, a dependência química.

A dependência dos efeitos psicoativos da maconha pode causar síndrome de abstinência no caso de cessação abrupta do uso. Os sintomas da síndrome de abstinência incluem agitação, insônia, irritabilidade, náusea e cãibras.

$\mathrm{O}$ aumento de incidência de casos de bronquite devido ao uso da maconha está comprovado, e especula-se a possibilidade de aumento de incidência de câncer de pulmão, como ocorre com o uso imoderado de tabaco.

\section{Cocaína}

Em sua forma vegetal e sem tratamento químico, a Erythroxelum coca é um produto originário de terras tropicais, utilizado de forma benéfica pelo homem há milhares de anos. Quando utilizada in natura, seus efeitos psicoativos são suaves, além de ser uma planta de adaptação restrita à região andina, sendo até hoje praticamente impossível o seu cultivo em outro clima do planeta. Por isso, foi apenas após a síntese do alcaloide cocaína (cloridrato de cocaína), em 1862, pela indústria farmacêutica alemã (mais especificamente pelos químicos Albert Nieman e Wilhelm Lossen), que a coca tornou-se a matéria-prima de uma das drogas psicoativas mais usadas e cobiçadas no mundo todo.

Pouco tempo após a síntese do cloridrato de cocaína, já havia a venda de múltiplos produtos à base de folha de coca na Europa e nos EUA, em forma de elixires, pastilhas, vinhos (entre os quais o vinho Mariani) e o famoso refrigerante Coca-Cola, que misturava, além da coca, também a cafeína extraída da noz de cola.

A cocaína, por mais de vinte anos, esteve disponível em todas as farmácias e entrepostos comerciais da Europa e dos EUA. Até a década de 1920, laboratórios alemães, holandeses e japoneses fabricavam centenas de toneladas de cocaína todos os anos. Durante certo tempo, suas propriedades fisiológicas fo- 
ram estudadas pelo jovem Freud, que era um de seus entusiastas. A descoberta das propriedades anestésicas da cocaína abriu as portas para o seu uso clínico na medicina, tendo sido o primeiro anestésico local utilizado, já em 1884, pelo médico Carl Koller, na cirurgia oftalmológica.

De panaceia utilizada para todos os males e prazeres, a cocaína com o tempo transformou-se naquilo que hoje compõe sua imagem negativa no imaginário popular. A campanha contra a cocaína começou no início do século XX, capitaneada pelos EUA e Reino Unido, em função de seus interesses comerciais (os alemães, principais concorrentes dos ingleses na época, eram os maiores produtores de cocaína). As conferências de Xangai, em 1909, Haia, em 1912, além da segunda conferência sobre o Ópio, em 1925, são marcos da campanha proibicionista contra drogas psicoativas como a cocaína, que culminam com a total proibição internacional após a conferência de 1961, em Nova Iorque.

Hoje em dia, parece ser evidente o absoluto fracasso do proibicionismo. A cocaína é utilizada, mundialmente, mais do que nunca, sendo veiculada nas sociedades por um tráfico que movimenta fabulosas quantias de dinheiro, mas que oferece um produto sem nenhum controle de qualidade, muitas vezes adulterado com vidro moído, talco, pó de mármore etc, que acaba por multiplicar muitas vezes os danos produzidos pelos efeitos do uso patológico. Na maioria das amostras colhidas dos produtos apreendidos ao comercio ilegal, verificou-se que mais da metade do pó, que se julgava ser cocaína pura, era composto por essas substâncias adicionadas.

Na América do Sul, única região produtora da folha de coca (os três principais produtores são Peru, Bolívia e Colômbia), o proibicionismo resulta em uma guerra catastrófica, que faz perecer por assassinato milhares de vítimas anualmente, além de mergulhar os aparelhos de estado latino-americanos na corrupção endêmica e de ser igualmente o subterfúgio para constantes ameaças contra a soberania desses países e efetiva invasão por parte da potência norte-americana, como o caso Noriega, ${ }^{5}$ no Panamá, e o plano Colômbia. ${ }^{6}$

\footnotetext{
5 Manuel Noriega foi Ditador do Panamá e Agente da Central Intelligence Agency (CIA). Teve um papel destacado no caso Irã-Contras, em que figuras-chave da CIA facilitaram o tráfico de drogas internacional, assim como o tráfico de armas para o Irã que, na época (década de 1980), estava sob embargo internacional. O objetivo principal era financiar a dissidência na Nicarágua sandinista. Ao vir à tona sua vinculação com o governo americano, os Estados Unidos invadiram o Panamá, prendendo Noriega sob a acusação de narcotráfico.

6 O plano Colômbia, criado em 2000 pelo governo norte-americano, inclui estratégias para combater o tráfico de drogas e a guerrilha colombiana. Acredita-se que, de fato, trata-se de uma intervenção geopolítica que mira as riquezas naturais amazônicas.
} 
Em termos médicos, o cloridrato de cocaína, além de seu efeito anestésico local, é um euforizante anorexígeno de melhor desempenho e bem menos tóxico que os habitualmente utilizados, como os derivados anfetamínicos (Escohotado, 2002). Ainda em comparação com as anfetaminas, o cloridrato de cocaína é uma droga cara, justamente por depender da produção da folha da coca, cultivada em região restrita (Andes, vales andinos e vale amazônico), o que, economicamente, por si só já justificaria a sua 'demonização' pelos países centrais, especialmente EUA e Inglaterra, como de fato vem ocorrendo há um século.

O uso recreativo abusivo da cocaína, em sua forma inalada ou intravenosa, pode produzir, entre outros inconvenientes, transtorno de humor, transtorno do sono, dores de cabeça e alterações na motricidade. Essas alterações gerais são encontradas também com o uso de compostos a ela relacionados, como o crack e a merla.

Uma lesão direta produzida pelo uso inadequado da droga em sua atual condição de ilegalidade é a congestão e a inflamação nasal, com aparecimento de úlceras e perfuração do septo nasal verificadas com o uso por inalação. Essas mesmas lesões, que são percebidas mais intensamente com o uso de crack, podem chegar à traqueia, brônquios e pulmões.

Os efeitos mais agudos (cerca de uma hora depois do uso abusivo ou mesmo durante o consumo) se dão por constrição dos vasos sanguíneos que irrigam o coração e o cérebro - vasoconstrição causada diretamente pela cocaína e seus derivados (Goodman \& Gilman, 1996). Como consequência, infarto agudo do miocárdio e derrames cerebrais podem ocorrer em pessoas jovens sem nenhuma doença previamente identificada.

Normalmente, lesões menores, que não matam, podem passar despercebidas, mas são lesões que comprometem, aos poucos, a capacidade intelectual do indivíduo, tornando tarefas de estudos, trabalhos e relacionamentos cada vez menos valorizados. Tarefas que eram executadas de maneira simples tornam-se cada vez mais difíceis. Contudo, uma vez verificada a lesão cerebral, ainda há possibilidade de recuperação, graças a um fenômeno presente no cérebro humano conhecido como plasticidade cerebral. Assim, um neurônio pode assumir a função do outro, se este morrer ou perder a capacidade de desempenhar suas funções. Esse fenômeno de plasticidade cerebral faculta ao indivíduo a capacidade de ter suas capacidades cerebrais recuperadas quando da interrupção do uso da cocaína. 
Por ser um euforizante, a cocaína aumenta o interesse sexual, no entanto, ao ser utilizada de forma repetida e abusiva, provoca disfunção e piora o desempenho sexual.

O uso de cocaína por via intravenosa pode causar, em virtude do compartilhamento das seringas com outras pessoas, uma série de doenças infecciosas graves, sendo a Aids apenas uma delas. A hepatite B e a hepatite C podem se tornar, muitas das vezes, mais graves que a própria Aids e são transmitidas por essa via. Tromboses nas pernas e braços e embolia pulmonar também são agravadas com essa prática.

Os riscos de ocorrerem abortos e lesões orgânicas e neurológicas no feto também são aumentados quando do uso de cocaína por gestantes. Doenças infecciosas como Aids, hepatites etc. também podem ser transmitidas ao feto, se a via de utilização da substância for injetável.

Para evitar os riscos do uso abusivo da cocaína, visando à redução de danos aos usuários com dificuldades de abstinência, pode-se prescrever a ingestão de muita água concomitante ao uso; a aquisição de equipamento próprio para cheirar ou se injetar (seringa só individual e limpa); o fracionamento das doses para evitar overdose; o uso de água destilada para a diluição da substância no preparo de doses injetáveis; a higienização das mãos precedendo a inoculação da dose; o cuidado de injetar lentamente a droga para avaliar o efeito e também para prevenir o risco de overdoses etc.

\section{Crack}

O nome crack é derivado do ruído produzido pelas pedras de cocaína de base livre quando volatilizadas através do calor. O crack, portanto, não é uma droga distinta da cocaína: é a própria cocaína transformada em um composto disponível para o consumo através do fumo. A invenção do crack deu-se na década de 1980, e seu sucesso está relacionado aos baixos custos para a sua produção e aquisição (em 1989, nos EUA, uma porção de crack valia em torno de 15 vezes menos que a mesma porção de cocaína em pó). Assim, essa droga disseminou-se pelos estratos economicamente mais baixos da população norte-americana, impedida de adquirir a cocaína em pó, em razão do seu alto custo, em virtude das dificuldades impostas pelas políticas de repressão à oferta e à demanda não apenas do cloridrato de cocaína em si, mas especialmente das substâncias necessárias para o seu preparo, como o éter e a acetona. O baixo preço da droga deve-se à pequena quantidade de cloridrato de cocaína utilizada na sua formulação. 
No processo de síntese do cloridrato de cocaína, é necessário, inicialmente, transformar as folhas de coca em uma pasta, misturando-as com querosene e macerando, logo em seguida, a mescla em ácido sulfúrico diluído. Essa pasta-base converte-se em cloridrato de cocaína ao ser purificada, acrescentando-se éter, ácido clorídrico e acetona. Se diluído em água e acrescido de bicarbonato de sódio, ou amônia, o cloridrato de cocaína se transforma em crack após ser aquecido. A diferença entre crack e freebase é que, no preparo deste último, se usa também, além de água e do bicarbonato de sódio, um solvente para a retirada das impurezas dissolvidas na água.

O crack é um preparado sólido e volatilizável, insolúvel em água, fato que impede sua absorção por outra via senão a fumada. O vapor derivado da queima do crack produz intenso efeito euforizante entre 10 a 15 segundos após sua inalação (enquanto o cloridrato de cocaína em pó, ao ser inalado, demora de 10 a 15 minutos para surtir o mesmo efeito). O complexo de sensações obtidas com o uso dessa base bicarbonada de coca pode durar de 5 a 15 minutos (enquanto o cloridrato dura entre 30 e 40 minutos). Como essas sensações são sentidas mais rapidamente que aquelas produzidas pelo 'pó', e como sua duração é fugaz, o usuário tende a fumar a droga diversas vezes, o que, supõem-se, intensifica seus efeitos colaterais.

As consequências agudas do uso não se limitam aos efeitos psicofarmacológicos (alucinações, delírios, taquilalia, agitação psicomotora, agressividade), mas também a alterações orgânicas gerais, como perda da neurorregulação da função pulmonar, edema pulmonar, hemorragia alveolar, barotrauma, reações de hipersensibilidade e doença pulmonar intersticial. A falta de apetite pode levar a uma grave desnutrição, e esta, consequentemente, a uma baixa de imunidade, facilitando o aparecimento de infecções oportunistas derivadas, especialmente a tuberculose e pneumonia. Por sua vez, os comportamentos de risco prevalentes às condições do uso (como associação ao tráfico, prostituição, roubos etc) favorecem a disseminação de hepatites e Aids, além, é claro, da violência.

Outras consequências do uso do crack são as lesões por queimaduras nas mãos, dedos, nariz, face, olhos (córnea e conjuntiva), lábios, cavidade oral, orofaringe, epiglote e laringe. Essas lesões são causadas pela inalação do vapor da droga em alta temperatura ou mesmo pela inalação de partículas metálicas incandescentes que se desprendem do material utilizado pelos usuários como cachimbo (em geral são utilizadas latas de alumínio, como as de refrigerantes ou cerveja, facilmente encontradas). 


\section{Inalantes}

Trata-se de uma das drogas mais utilizadas no Brasil, especialmente por populações jovens marginalizadas econômica e socialmente. São compostos sintéticos, em geral derivados do petróleo, que se volatizam com muita facilidade. A cola de sapateiro, o benzeno, a gasolina, os fluidos de isqueiro e os aerossóis são os exemplos mais comuns.

Os inalantes produzem efeitos neurotóxicos graves. Muitos deles contêm chumbo e outros metais pesados que se acumulam no corpo, causando lesões muitas vezes irreversíveis. Também produzem depressão no sistema nervoso, e seu uso pode ser intensificado com o tempo, pela dependência e tolerância que provocam. Os efeitos dos inalantes no SNC se dão por um mecanismo muito semelhante ao que ocorre com o álcool, ou seja, de uma forma difusa, afetando a permeabilidade normal das membranas dos neurônios.

Alterações no comportamento e na motricidade são verificadas por acometimento do SNC, dentre elas, tontura, falta de coordenação motora, letargia e fraqueza muscular generalizada, reflexos deprimidos, fraca coordenação, retardo psicomotor, tremores, visão turva ou dupla e coma.

A morte pelo uso de inalantes pode ocorrer por parada respiratória, que com frequência tem como causa um efeito direto no SNC, ou até mesmo por asfixia causada por aspiração de vômito. Arritmias cardíacas também podem ocorrer.

Lesões no fígado não são incomuns, assim como lesões nos rins, como consequência de um distúrbio denominado rabdomiólise. A rabdomiólise origina-se de uma lesão maciça da musculatura, que por sua vez ocorre mediante o efeito direto dos inalantes nas células do tecido muscular. Os compostos tóxicos derivados dessa lesão, ao serem carreados pela circulação aos rins, produzem insuficiência renal, que pode ser irreversível, levando o indivíduo a depender dos dolorosos procedimentos de diálise para sobreviver.

\section{Opioides}

São opioides a morfina, a heroína e a codeína. Como a síntese em laboratório desses compostos é possível, podem surgir compostos novos com características farmacológicas ligeiramente diversas. A ação dos opioides no SNC ocorre sobre receptores moleculares específicos para a substância, os chamados receptores opioides, além de produzir ações sobre outros grupos de receptores não específicos. 
Normalmente, essas substâncias são lipossolúveis. Como o SNC é basicamente formado por gordura, conclui-se que é no tecido nervoso que os opioides exercem com maior intensidade suas funções, podendo comprometer a memória, assim como a cognição, o humor e as funções motoras, manifestando-se pela incoordenação e pela fala arrastada.

O uso de opioides por via intravenosa pode, no caso de compartilhamento de seringas, causar uma série de doenças infecciosas graves, tais como Aids, hepatite B e hepatite C. Doenças neurológicas, como a doença de Parkinson, comumente se manifestam por causa do uso inapropriado de opioides.

É importante citar a interação que os opioides têm com medicações utilizadas para o tratamento de estados depressivos e outras condições clínicas. O uso simultâneo dessas substâncias pode resultar em grave disfunção do sistema nervoso autônomo, causando alterações cardíacas, como arritmias e instabilidades hemodinâmicas, que resultam, não raramente, em convulsão e morte.

\section{Club Drugs}

As chamadas club drugs (ou designer drugs) referem-se a um grupo de drogas usadas principalmente por jovens adultos em festas, discotecas e raves. Não apresentam uma uniformidade de efeitos, algumas são sedativas (GHB, nitratos), outras, estimulantes (metanfetaminas como o 4MTA, PMA e PMMA), e outras, alucinógenas (ecstasy, LSD, quetamina, 2CB e 2-CT-7). Apresentamos a seguir as mais comuns no Brasil.

\section{Ecstasy}

O ecstasy (MDMA) é um derivado anfetamínico cuja composição química é muito próxima da mescalina, que é um alucinógeno. É essa combinação de efeitos (euforizante e alucinógeno) que explica sua sedutora singularidade.

Trata-se de uma droga sintética que apresenta um histórico de uso na sociedade bastante longo, uma vez que sua 'descoberta' ocorreu muito antes das outras anfetaminas ou mesmo dos alucinogéneos (sintéticos). Foi patenteada em 1914, na Alemanha, pelos laboratórios Merck, como um medicamento supressor do apetite, que nunca chegou a ser comercializado para esse fim, mas esteve abandonada até a década de 1950, quando foram retomadas as experiências para sua utilização com fins específicos, como nos interrogatórios policiais e psicoterapias.

A popularização de seu consumo recreativo foi detectada durante os anos 60, nos EUA, fato que levou à sua proibição em 1985, bem de acordo com a 
tradição proibicionista e puritana daquele país. No final dos anos 80 , começou a espalhar-se por toda a Europa, acompanhando diversas modas musicais e o estilo de vida de alguns locais do mediterrâneo.

Sem dúvida, o ressurgimento dessa droga foi um dos temas mais comentados dos últimos anos do milênio passado, apesar de o seu consumo não ser de envergadura e de suas consequências serem menos dramáticas do que se imaginava a princípio.

Trata-se de uma substância administrada normalmente por via oral, em forma de barras, cápsulas ou pó, sendo o uso das primeiras o mais frequente. Apresenta-se em diversos tamanhos e cores. Em decorrência de sua proibição, deve ter-se em conta que as unidades de MDMA disponíveis variam, na realidade, quer no seu aspecto exterior, quer no seu conteúdo (pastilhas e comprimidos semelhantes diferem na sua composição e proporção), em virtude das necessidades de lucro selvagem que o comércio desregulado inerente ao tráfico impõe. Os usuários tendem a considerá-las como uma única droga, ignorando, em muitas ocasiões, o que na verdade estão utilizando.

A dose efetiva de MDMA oscila entre 75/150 miligramas por via oral. Os primeiros sintomas aparecem entre trinta e sessenta minutos após ser ingerida, alcançando em duas horas a chamada fase de estabilidade. A partir daí, os efeitos principais começam a diminuir, desaparecendo depois de, em média, cinco horas. Algumas consequências residuais, sobretudo psicológicas, podem manter-se mesmo depois de o fármaco ter sido completamente metabolizado pelo organismo (o que ocorre aproximadamente dois dias após sua ingestão).

Tendo em conta que quase nunca se sabe, com precisão, quais são os componentes do produto que se vende como ecstasy, e que os seus efeitos podem variar de forma considerável, enumeraremos, a seguir, as consequências mais frequentes do consumo de MDMA.

Pode-se dividir os efeitos do ecstasy em desejados e tóxicos. Entre os efeitos desejados pelo usuário, encontram-se os psíquicos e os físicos. Os efeitos psíquicos buscados são, por ordem de frequência, a sensação de intimidade e de proximidade com outras pessoas, o aumento da capacidade comunicativa, euforia, loquacidade, despreocupação, autoconfiança, expansão da perspectiva mental, incremento da consciência das emoções, diminuição da agressividade e intensificação da consciência sensitiva. Os principais efeitos buscados no corpo são o aumento da energia e da resistência à fadiga causada pela repetição de pequenos e médios esforços. 
Os efeitos tóxicos do ecstasy surgem em virtude de diversas alterações de risco que ele produz no organismo. Uma dessas alterações é resultante da associação do esforço físico com a droga, que pode elevar a temperatura corpórea a mais de $42^{\circ} \mathrm{C}$, sendo, assim, potencialmente fatal. A droga produz também aumento na liberação do hormônio antidiurético, ou seja, o organismo passa a ter dificuldades para eliminar líquidos. Por isso, caso o indivíduo venha a beber muita água (devido ao esforço físico nas festas dançantes e, principalmente, pelo aumento anormal da temperatura corpórea), pode sofrer uma espécie de intoxicação pelo excesso de líquidos no corpo, o que também é potencialmente fatal.

Em virtude do número razoável de pessoas que se supõe já terem experimentado o ecstasy nas últimas décadas e da inexistência de consumidores que mantêm uma utilização crônica - além da falta de evidência de que possa produzir efeitos de tolerância ou uso compulsivo, apesar da evidência de perdas em diversos níveis -, pode-se dizer que essa droga não provoca dependência química. Contudo, como já foi descrito, não está isenta de outros riscos causados não apenas pela sua toxicidade, mas, em especial, pelas características insalubres que o próprio ilegalismo produz.

\section{Quetamina}

A quetamina foi sintetizada em 1962 para uso humano como anestésico, sendo utilizada atualmente na medicina veterinária. Pertence a um grupo de substâncias que produzem alterações de sensopercepção, tal como o PCP e outras.

Apresenta-se na forma de pó branco, líquido ou tablete, podendo ser consumida, portanto, por inalação, injeção ou via oral.

É um inibidor não competitivo dos neuroreceptores e influencia a transmissão dopaminérgica, induzindo sintomas psicóticos. Tem ação no córtex pré-frontal, o que pode explicar alguns dos seus efeitos na memória e no pensamento. Os efeitos da quetamina, além de alucinógenos, induzem uma combinação entre manifestações euforizantes e sedativas. Após a ingestão oral, os efeitos iniciam-se em média entre 15 e 20 minutos e duram, pelo menos, 90 minutos. Ela é rapidamente metabolizada pelo organismo, não se detectando vestígios na urina após 48 horas do uso (Goodman \& Gilman, 1996).

Em doses baixas, os efeitos alucinógenos apenas existem em condições de falta de estimulação sensorial, como na escuridão ou com os olhos fechados. Muitas vezes, é preferida a outras do mesmo tipo, nomeadamente o PCP, 
pois seus efeitos alucinógenos não são intensos nem prolongados. No entanto, as alterações na capacidade de julgamento e coordenação podem persistir por 24 horas.

Em doses tóxicas, provocam desorientação espaço-temporal e manifestações dissociativas. Problemas respiratórios, alterações motoras e gastroentéricas também podem ocorrer. O 'retorno' à realidade geralmente é lento, e o usuário demora a ter consciência do próprio corpo e dos movimentos.

\section{Ácido Gama-Hidroxibutírico (GHB)}

Muitas vezes conhecido como 'ecstasy líquido', o GHB, na verdade, não tem nenhuma relação com essa substância, que é derivada das anfetaminas. O GHB é naturalmente produzido pelo corpo humano, mas sua função ainda não está bem esclarecida. Foi sintetizado pela primeira vez em 1920 na forma de um líquido inodoro, ligeiramente salgado ao paladar, consumido por via oral. Classificado como um indutor do sono, é depressor do SNC, produzindo efeitos anestésicos e sedativos com ação psicodélica.

O GHB depois de ingerido liga-se a receptores Gaba, no tecido cerebral, atingindo com facilidade altas concentrações. Em doses baixas, pode ser ligeiramente estimulante, e em doses mais elevadas tem efeitos sedativos, podendo provocar, eventualmente, depressão respiratória se associado ao álcool, benzodiazepinas ou outros depressores.

A potência das drogas faz variar os seus efeitos, que geralmente começam a fazer sentir-se 10 minutos após o consumo e podem durar duas a três horas. Os efeitos residuais permanecem, em geral, por um dia inteiro. Em doses baixas, o GHB tem um efeito de euforia semelhante ao do álcool e pode fazer o consumidor sentir-se relaxado, feliz e sociável, com mais energia, sensação de bem-estar, euforia, relaxamento, aumento da confiança e desinibição. Em algumas pessoas, pode apresentar efeitos desagradáveis como náuseas, vômitos, dores de cabeça, sonolência, tonturas, amnésia, problemas respiratórios e até perda da consciência. O GHB parece não provocar dependência física ou psicológica nem tolerância. 


\section{Referências}

ALARCON, S. O Diagrama das Drogas: cartografia das drogas como dispositivo de poder na sociedade brasileira contemporânea, 2008. Tese de Doutorado, Rio de Janeiro: Escola Nacional de Saúde Pública Sergio Arouca, Fundação Oswaldo Cruz. (Mimeo.)

BRAUDEL, F. Alimentation et catégories de l'histoire. In: Annales ESC, 16(4): 725, 1961.

CARLINI E. A. et al. I Levantamento Domiciliar sobre o Uso de Drogas Psicotrópicas no Brasil. São Paulo: Centro Brasileiro de Informações sobre Drogas Psicotrópicas da Universidade Federal de São Paulo (Cebrid/Unifesp), Secretaria Nacional Antidrogas (Senad), 2001.

CARNEIRO, H. Pequena Enciclopédia da História das Drogas e Bebidas. Rio de Janeiro: Elsevier, 2005.

CHALOULT, L. Une nouvelle classification des drogues toxicomanogènes. Toxicomanies, 4(4): 371-375, 1971.

CHERMACK S. T. et al. Gender differences in the development of substance-related problems: the impact of family history of alcoholism, family history of violence, and childhood conduct problems. Journal of Studies of Alcohol and Drugs, 61(6): 845-52, 2000 .

ESCOHOTADO A. Historia General de las Drogas. Madrid: Espasa Fórum, 2002.

GETTMAN, J. Lost taxes and other costs of marijuana laws. The Bulletin of Cannabis Reform, 2007. Disponível em:<www.drugscience.org>. Acesso em: 10 set. 2007.

Goodman, L. S. \& GILMAN, A. Las Bases Farmacológicas de la Terapéutica. 9. ed. Mexico: Editorial McGraw-Hill Interamericana, 1996.

JUNTA INTERNACIONAL DE FISCALIZAÇÃO DE ENTORPECENTES (JIFE). Relatório Anual 2006 da Junta Internacional de Fiscalização de Entorpecentes. Brasília: Escritório das Nações Unidas contra Drogas e Crimes, 2006. (Escritório das Nações Unidas contra Drogas e Crimes, divulgado em $1^{\circ}$ de março de 2007)

MOREIRA, T. C. O Uso de Álcool e a Violência Interpessoal, 2008. Dissertação de Mestrado, Porto Alegre: Programa de Pós-graduação em Ciências Médicas, Universidade Federal de Ciências da Saúde de Porto Alegre.

WATSON, S. J.; BENSON JR., J. A. \& JOY, J. E. Marijuana and medicine: assessing the science base: a summary of the 1999 Institute of Medicine Report. Archives of General Psychiatry, 57(6): 547-552, 2000. 


\title{
Critérios para o Diagnóstico de Dependência Química
}

\author{
Sergio Alarcon
}

Segundo a Organização Mundial da Saúde (OMS, 2001), cerca de 10\% das populações dos centros urbanos de todo o mundo consomem abusivamente substâncias psicoativas, independente da idade, sexo, nível de instrução e poder aquisitivo. Outro estudo conduzido pela OMS, em 2003, sobre a carga global de doenças, estima que o tabaco, o álcool e as drogas ilícitas correspondam a, respectivamente, $4,1 \%, 4 \%$ e $0,8 \%$ de todas as morbidades no mundo. Ainda, segundo o mesmo estudo, a carga de doenças inclui transtornos físicos (cirrose hepática, miocardiopatia alcoólica, polineuropatia, demência etc.) e lesões decorrentes de acidentes (industriais e automobilísticos, por exemplo).

No Brasil, uma pesquisa encomendada pelo governo federal sobre os custos dos acidentes de trânsito revelou que há uma relação entre o uso do álcool e outras drogas e a gravidade das lesões. Como os acidentes e as violências ocupam a segunda causa de mortalidade geral, sendo a primeira causa de óbitos entre pessoas de 10 a 49 anos de idade - perfil que se mantém nas séries históricas do Sistema de Informações sobre Mortalidade (SIM) do Ministério da Saúde entre 2000 e 2008 -, seria importante procurar entender em que condições as drogas são determinantes de uma maior exposição das pessoas a comportamentos de risco. Isso inclui os efeitos inerentes aos hábitos culturais e também aqueles provocados pelas legislações que procuram regular esses hábitos quando relacionados ao uso de drogas. 
Dados epidemiológicos sobre o consumo de drogas no Brasil, obtidos a partir do I Levantamento Domiciliar sobre Uso de Drogas, realizado, em 2001, pelo Centro Brasileiro de Informações sobre Drogas Psicotópicas (Cebrid), da Universidade Federal de São Paulo (Unifesp), indicam que a droga mais consumida no país é o álcool, com uso na vida (ou seja, qualquer uso, inclusive o uso experimental uma vez na vida) por $68,7 \%$ da população, seguido do tabaco, com $41,1 \%$. Em proporções substancialmente mais baixas, constam as demais drogas, como a maconha, com $6,9 \%$; os solventes, com 5,8\%; os benzodiazepínicos, com $3,3 \%$; e a cocaína, com $2,3 \%$. Note-se a disparidade entre o consumo de drogas lícitas, como álcool e tabaco, em relação ao uso das drogas ilícitas citadas (Carlini et al., 2001).

Estima-se que aproximadamente $20 \%$ dos pacientes tratados na rede primária apresentam um padrão de uso de álcool considerado abusivo ou de alto risco. Essas pessoas têm seu primeiro contato com os serviços de saúde por intermédio de clínicos gerais, que raramente detectam a presença de acometimento por tal uso (por uma série de razões, que vão desde as más condições de trabalho até a formação técnica deficiente), o que tem repercussão negativa sobre as possibilidades de diagnóstico e tratamento. Percebe-se que, no geral, o foco da atenção está voltado para as doenças clínicas decorrentes da dependência - que ocorrem tardiamente -, e não para a dependência subjacente.

O diagnóstico e o tratamento precoces da dependência química (seja do álcool ou de outras drogas) têm papel fundamental no prognóstico desse transtorno, que se amplia, de um ponto de vista global de prevenção e promoção da saúde, e se complica, já que, de maneira geral, há expressivo despreparo e desinformação das pessoas que lidam com o problema, sejam elas usuários, familiares ou mesmo profissionais.

Não se trata, simplesmente, de constatar a utilização de drogas, uma vez que, em termos estritos de avaliação médica, isso não tem muito significado. Verificado o uso, deve-se primeiramente avaliar até que ponto este está relacionado com a dependência química, ou se diz respeito exclusivamente à 'experimentação', ou, ainda, ao 'uso abusivo sem dependência'. No entanto, se é importante a identificação precoce de casos que poderiam evoluir para situações de maior gravidade, também se deve tomar cuidado para não se 'psiquiatrizar' um comportamento considerado normal em determinado contexto cultural específico. Um diagnóstico clínico equivocado, que confunda experimentação com uso abusivo ou com dependência química, pode acarretar ações 
que signifiquem grave 'iatrogenia', ou seja, a produção de dano com base na intervenção técnica sanitária. Por isso, o objetivo aqui é favorecer uma melhor abordagem diagnóstica por equipes interdisciplinares da área da saúde. Obviamente, por tratar-se de um texto esquemático, serve apenas como sugestão para uma maneira de pensar o diagnóstico, que necessitará ser criticada e, eventualmente, complementada.

O processo pelo qual o consumo de substâncias em certas pessoas evolui para padrões de comportamento compulsivo de busca e utilização, chegando a provocar a incapacidade do autocontrole, mesmo à custa de muitos prejuízos, parece ser a consequência de um amálgama que abrange fatores psicológicos, neurobiológicos e sociais de difícil apreensão. No entanto, mesmo sendo obscuros os mecanismos que levam o indivíduo a se tornar farmacodependente, o diagnóstico e o tratamento para a dependência são plenamente possíveis e viáveis. Na verdade, por se tratar de um fenômeno 'complexo', ou seja, que permeia praticamente todas as valências possíveis da vida de um indivíduo, a dependência química requer um diagnóstico interdisciplinar, por meio do qual tanto uma equipe de saúde quanto o próprio usuário e seus familiares possam apoiar-se para construírem estratégias de transformação. Essas estratégias devem visar, idealmente, não apenas à abstinência ou à exclusiva redução dos danos, mas, principalmente, à possibilidade de construção de horizontes vitais que sejam, a um só tempo, exequíveis e sedutores para o utente. ${ }^{1}$

Ninguém consegue, com facilidade e sem sofrimento, abandonar hábitos longamente adquiridos, quanto mais hábitos produtores de prazeres. As drogas tornam-se hábitos (ou seja, seu uso torna-se um 'costume', sendo constantemente repetido) exatamente pela sedução que provocam. O objetivo último que começa com o diagnóstico da dependência química é ajudar na construção de condições de vida cuja sedução possa concorrer com um prazer que se tornou, ao mesmo tempo, nocivo; hábito causador de uma satisfação efêmera cujo custo é pago à prestação sob a forma de transtornos de todas as ordens (Rotelli, 1991).

\footnotetext{
1 Será dada preferência ao termo utente no lugar de usuário ou paciente, pois, em primeiro lugar, trata-se de uma designação corrente na saúde mental pós-reforma psiquiátrica; e, em segundo lugar, trata-se de um termo que denota uma atividade inerente ao próprio dependente químico, que é essencial na relação terapêutica que se pretende construir nos serviços públicos voltados para a atenção do adito. Utente significa aquele que, graças a algum grau de independência, e conforme a sua vontade, usufrui de algo.
} 


\section{Apontamentos sobre o Diagnóstico Clínico da Dependência Química}

O diagnóstico da farmocodependência, como mencionado, não é simples, sendo necessária a superposição de perspectivas diversas para a mensuração de sua real dimensão. Essas perspectivas incluem aspectos biológicos, psicológicos, sociais e culturais, que, por fim, desembocam na especificidade daquela subjetividade acometida pelos efeitos nocivos do hábito de usar drogas. Nenhuma perspectiva tomada isoladamente é suficiente para dar conta dos aspectos essenciais do fenômeno da dependência.

$\mathrm{Na}$ área médica, tem-se tornado consenso identificar o tipo de usuário segundo a maneira pela qual ele incorpora ao seu cotidiano o uso de drogas. É chamado de 'experimentador' aquele que delas faz consumo esporádico, com nenhum ou pouco impacto sobre sua saúde. Difere do usuário social ou recreativo, que utiliza drogas repetidas vezes, de forma controlada, sem a ocorrência de alterações em suas funções orgânicas, psicológicas e sociais. Considera-se como 'abuso' ou 'uso nocivo' a utilização que frequentemente extrapola os valores médicos e culturais aceitos quanto à quantidade, frequência de uso e via de administração. O abusador apresenta recorrentes intoxicações, com diversos prejuízos, sejam físicos, psicológicos ou sociais. Já a 'dependência química' é explicada em termos diagnósticos, segundo o DSM-IV (1995), pela autoadministração repetida de drogas, que em geral leva à tolerância, à abstinência e a um padrão compulsivo de uso, com histórico evolutivo de, no mínimo, 12 meses.

Pode-se dizer que as substâncias psicoativas interferem na função normal do cérebro, alterando os processos normais de acumulação, liberação e eliminação de neurotransmissores ${ }^{2}$ endógenos. Alguns desses neurotransmissores que se relacionam com as substâncias psicoativas são a dopamina, a serotonina, a noradrenalina, o ácido gama-aminobutírico (Gaba), o glutamato e os opioides endógenos.

Em geral, quando praticamos alguma ação cujo resultado final é benéfico, do ponto de vista orgânico - como, por exemplo, o ato de nos alimentarmos -, o sistema nervoso libera alguns neurotransmissores que ativarão as chamadas 'vias cerebrais de recompensa', fazendo-nos sentir prazer. O sistema de recompensa não gera, contudo, apenas prazer, mas também saciedade, fazendo com

Neurotransmissores são substâncias químicas produzidas pelas células do sistema encefálico, os neurônios responsáveis pelo envio de informações a outras células do corpo. 
que, após determinado limite, o impulso para a repetição do ato se interrompa. A cessação do ato é imperiosa para que um ato análogo venha a se constituir futuramente, tornando possível a repetição da sensação de prazer. Da mesma forma, é o desprazer implícito na sensação de falta (de comida, água, sexo etc.) que gera a busca do prazer que trará a saciedade, estabelecendo um circuito natural de privação-prazer-saciedade. Sem esse circuito de recompensa o indivíduo perderia o interesse pela vida e seria incapaz de subsistir.

Esse mecanismo bioquímico e psicológico é também denominado 'reforço positivo-negativo'. A ativação desse circuito pode ocorrer de maneira artificial com o uso de drogas, o que, por si só, não acarreta necessariamente a farmacodependência. Apenas o uso contínuo (crônico) de determinadas quantidades de psicoativos geraria o desenvolvimento de um processo de 'aprendizagem' neuronal (neuroadaptação), como efeito paradoxal da 'satisfação' provocada pelo seu uso (efeito agradável ou 'positivo'). A busca natural pelo prazer tornar-se-ia, então, descontrolada, pois a neuroadaptação imporia ao indivíduo uma sensação situada entre a privação e o prazer, sem a mediação temporal da sensação de saciedade. Ou seja, pode-se dizer que um dos aspectos que explicam a dependência química seja a avidez crônica, que faz com que o indivíduo passe a buscar com frequência desmedida um prazer insaciável. O uso da substância deixaria, então, de ser controlado pela expressão da sequência privação-prazer-saciedade, reduzindo-se ao tudo ou nada do circuito privação-prazer-privação.

Portanto, os efeitos da satisfação ou do prazer não são os únicos a justificarem os comportamentos associados à dependência. Os sintomas de abstinência (efeito desagradável da privação ou efeito 'negativo') também acabam contribuindo para a manutenção do consumo abusivo. Por 'abstinência', entende-se uma alteração comportamental mal-adaptativa, com elementos cognitivos e fisiológicos que ocorrem quando, transcorrido certo tempo após um uso pesado da droga, a diminuição de sua concentração plasmática leva a sintomas desagradáveis variados, o que compele a pessoa a voltar a usar a droga, seja para aliviar os sintomas desagradáveis, seja para evitar o retorno desses sintomas.

O processo que leva ao comportamento desmedido da neuroadaptação pode ser entendido através do mecanismo de bloqueio da recaptação de um neurotransmissor depois de sua liberação, fato que ocasiona a exacerbação dos efeitos normais ocasionados por esse neurotransmissor, gerando ou uma subsensibilidade ('tolerância') ou uma hipersensibilidade ('sensibilização') à droga de abuso. 
Genericamente, deve-se entender por tolerância a necessidade de crescentes quantidades da substância para se atingir o efeito desejado. Pode também ocorrer o fenômeno denominado 'tolerância cruzada', quando o uso repetido de uma determinada substância confere tolerância a outras substâncias da mesma categoria bioquímica (por isso, alguns anestésicos quando utilizados em alcoolistas não fazem efeito). O contrário da tolerância, a 'sensibilização', também denominada 'tolerância reversa', ocorre quando há aumento da resposta neuropsicológica inicial com o uso crônico da mesma dose da substância. A tolerância, por se apresentar de forma variável entre os indivíduos e os tipos de drogas usadas, pode ser difícil de se determinar com base, apenas, na anamnese.

Contudo, nem a tolerância nem a abstinência são critérios necessários ou suficientes, quando tomados isoladamente, para um diagnóstico adequado de dependência. Pode-se encontrar tanto o uso compulsivo sem tolerância e abstinência (caso do uso de canabinoides) quanto tolerância e abstinência em situações nas quais não há evidência de uso compulsivo.

O que caracteriza a dependência química e pode definir um diagnóstico clínico é a presença de um conjunto de sintomas comportamentais, cognitivos e fisiológicos, indicando que o indivíduo continua utilizando uma substância, apesar dos significativos prejuízos a ela atribuídos (DSM-IV, 1995). Assim, pode-se estabelecer um padrão de uso característico da dependência, que inclui: o uso da substância em dose e/ou tempo acima do pretendido inicialmente; o fracasso em diversas tentativas de controlar ou reduzir o uso da substância; o tempo excessivo gasto para a recuperação dos efeitos ou para a aquisição da droga; uma importante disfunção social, com redução drástica de atividades recreativas e ocupacionais; a manutenção peremptória do uso da substância mesmo diante do reconhecimento das perdas sociais, econômicas e afetivas.

Outro critério diagnóstico amplamente utilizado no Brasil é aquele produzido pela Classificação Internacional de Doenças, atualmente em sua décima edição, a CID-10. Com base nessa classificação, a dependência de substâncias compreende seis critérios, e uma pessoa é considerada dependente se apresentar pelo menos três desses critérios (Quadro 1). Há dois critérios biológicos, abstinência e tolerância, e quatro critérios que incluem elementos cognitivos: desejo compulsivo; dificuldades de autocontrole; dificuldade de se proteger dos danos evidentes provocados pelo uso; e restrição dos interesses e ampliação progressiva do tempo despendido com a droga. 
Quadro 1 - Critérios de dependência de substâncias segundo a CID-10 (Presença de três ou mais dos seguintes sintomas em qualquer momento durante o ano anterior)

1. Desejo forte e compulsivo de consumir a substância;

2. Dificuldades para controlar o comportamento de consumo de substâncias em termos de início, fim ou níveis de consumo;

3. Estado de abstinência fisiológica, quando o consumo é suspenso ou reduzido, evidenciado por síndrome de abstinência característica ou consumo da mesma substância (ou outra muito semelhante) com a intenção de aliviar ou evitar sintomas de abstinência;

4. Evidência de tolerância, ou seja, necessidade de doses crescentes da substância psicoativa para a obtenção dos efeitos anteriormente produzidos com doses inferiores;

5. Abandono progressivo de outros prazeres ou interesses em virtude do consumo de substâncias psicoativas, aumento do tempo empregado na aquisição ou consumo da substância ou na recuperação de seus efeitos;

6. Persistência no consumo das substâncias apesar de provas evidentes de consequências manifestamente prejudiciais, tais como lesões hepáticas causadas por consumo excessivo de álcool, humor deprimido consequente a um grande consumo de substâncias, ou perturbação das funções cognitivas relacionada com a substância.

Fonte: adaptado de WHO, 1992.

\section{Diagnóstico da Dependência Química e a Comorbidade}

Na medicina geral, utiliza-se o termo 'comorbidade' quando dois (ou mais) transtornos de saúde, de etiologias distintas, coexistem em um mesmo indivíduo. Sua adequação à psiquiatria e à saúde mental é motivo de controvérsias, embora haja poucos estudos sobre o tema. Essas controvérsias se relacionam à própria dificuldade da psiquiatria em se adequar à teoria das doenças reinante na medicina geral, em virtude da ausência de uma etiologia biológica identificável para as ‘doenças' mentais. Segundo Camargo Jr., as doenças

são coisas, de existência concreta, fixa e imutável, de lugar para lugar e de pessoa para pessoa; as doenças se expressam por um conjunto de sinais e sintomas, que são manifestações de lesões, que devem ser buscadas, por sua vez, no âmago do organismo e corrigidas por algum tipo de intervenção concreta (leia-se, medicamentosa ou cirúrgica). (Camargo Jr., 2007:65-66) 
Ainda segundo Camargo Jr., essa definição de doença como 'coisa' é compatível com o modelo de história natural da doença, que esquematiza as relações dinâmicas do ciclo saúde/doença, compondo-o a partir de três pilares: o agente etiológico, o doente e o meio ambiente.

O agente etiológico se define, com base nessa tese, pelas forças dispostas no ambiente, que criam o estímulo patológico no indivíduo, sendo a doença a resposta do indivíduo ao estímulo, proporcionando alterações que levam a recuperação, defeito, invalidez ou morte (Leavell \& Clark, 1976). Determinar o agente etiológico é, portanto, determinar a causa da doença. Supondo que qualquer tratamento que vise à cura de doenças objetive a eliminação de suas causas (não apenas a eliminação de seus efeitos ou sintomas), então, de forma geral, todo o esforço diagnóstico-terapêutico da medicina curativa repousa sobre a determinação e a retirada do agente etiológico.

Sabe-se que a psiquiatria carece de agentes etiológicos para explicar as causas das doenças mentais, identificando, no máximo, como um deus ex-machina, as imprecisas 'causas' genéticas e hereditárias. Esse vácuo explicativo, determinado pela ausência do agente etiológico, sustenta a imprecisão relativa ao entendimento dos mecanismos de produção da doença que, a rigor, torna-se mera conjectura. Assim, a identificação e a conjugação dos sintomas em síndromes que distinguem uma doença como tal dependem de uma série de fatores, em geral extracientíficos, situação que, necessariamente, joga a medicina mental no limiar da medicina científica. E o que afinal se censura em relação à psiquiatria, como responsável por iatrogenia nada desprezível é o cientificismo ${ }^{3}$ expresso pela insistência em buscar no modelo biológico da história natural das doenças a justificação para seu repertório de condutas, ocasionando, paradoxalmente, a excessiva medicalização do sofrimento (o que explica, em parte, a explosão do uso de medicamentos, como Valium ${ }^{\circledR}$, Prozac $^{\circledR}$, Ritalina $^{\circledR}$ etc, para contornar condições de ansiedade, tristeza ou inquietude).

Na história da medicina mental, o jogo entre a contestação e a reafirmação de suas pretensões científicas é que acaba fazendo do termo 'reforma psiquiátrica' quase que um eufemismo para 'psiquiatria'. É no interior desse jogo que

\footnotetext{
3 O cientificismo é uma posição ideológica e ufanista que justificou, e ainda justifica, uma série de aberrações éticas em nome da infalibilidade da ciência - o que inclui a crença, por exemplo, de que é a ciência a única forma de descrição neutra e objetiva do real. Não podemos esquecer ideias eticamente questionáveis nascidas no seio do cientificismo, como o higienismo, o darwinismo social, a antropologia criminal de Lombroso etc. É importante enfatizar aqui que denunciar o cientificismo não é o mesmo que agir de forma anti-intelectualista ou contra a ciência, pelo contrário.
} 
se define, segundo a época, essa ou aquela entidade nosológica. Em outras palavras, os momentos nos quais se hesita entre o arcaico e o moderno formam a constante que delineia a temporalidade da medicina mental, onde, por exemplo, em um dia é possível o diagnóstico de psicose maníaco-depressiva e, no outro, o de transtorno bipolar (que o substituiu).

O esforço para se definir os transtornos psiquiátricos como síndromes fica evidente nas elaborações dos manuais de classificação diagnóstica supracitados, o CID-10 e o DSM-IV. O que esses manuais apresentam, na verdade, é o registro de observações semiológicas do que é aceito pela comunidade científica da época como sintoma ou grupo de sintomas aparentados e/ou interdependentes. São passíveis de revisões periódicas, em virtude não de uma mudança de paradigma científico, pois não há conceitos definidores bem fundamentados empiricamente, mas em virtude de um rearranjo no consenso temporário e descritivo (e não explicativo, já que sempre falta o agente etiológico) das síndromes mentais. Cada revisão acompanha, amiúde, a adequação política, social e cultural da medicina mental às forças hegemônicas de sua época. Por isso, os critérios definidores de patologias podem ser tão fluidos e imprecisos quanto aqueles que, por exemplo, determinaram a entrada e, posteriormente, a saída da homossexualidade do rol das doenças mentais (Belmonte, 2009).

Pode-se dizer que ocorre com frequência, na psiquiatria, aquilo que, no caso das outras especialidades médicas, seria classificado como 'quadro mórbido mal definido', produzindo uma habitual 'zona cinzenta' diagnóstica, na qual o desencontro terapêutico é a regra. Nesse contexto, agregam-se dificuldades para que se estabeleça, com alguma precisão, os fatores de risco psiquiátricos que poderiam eventualmente influenciar o uso abusivo de drogas. Ou seja, em geral, as relações de causa e efeito entre as drogas e os transtornos mentais são estabelecidas com um baixo grau de confiabilidade para um diagnóstico que se desejaria preciso e científico. Mesmo assim, é terapeuticamente estratégico pesquisar na farmacodependência as relações entre diagnósticos múltiplos, que necessitam ser dimensionados minimamente de maneira a permitir uma hierarquização dos problemas para o planejamento mais eficaz das ações de cuidado e tratamento.

Um esquema simples para se avaliar as relações entre dependência química e comorbidade, proposto por Frances, Widiger e Fyer (1990), encontrase resumido (com modificações) a seguir. Segundo os autores, é necessário avaliar se a dependência química (DQ) predispõe a comorbidade (CM) ou 
se contribui para a manifestação da CM (em caso positivo, a DQ é primária e predispõe a $\mathrm{CM}$ ); se a CM predispõe a DQ ou se contribui para a manifestação da DQ (em caso positivo, a CM é primária e predispõe a manifestação da DQ); se a DQ e a CM são influenciadas por um mesmo fator predisponente (em caso positivo, tanto a DQ quanto a CM são secundárias ao fator primário); se a associação entre DQ e CM ocorre por acaso ou se decorre de sua maior prevalência na população em geral (não há relação entre DQ e CM); e se a DQ e a CM pertencem, na verdade, a um mesmo transtorno, tendo sido equivocadamente separadas (DQ e CM manifestam-se como variações sintomatológicas de um mesmo transtorno).

Obviamente, o fenômeno da comorbidade deve ser visto, sempre que possível, de maneira interdisciplinar, uma vez que não se pode reduzir a farmacodependência a uma condição apenas médico-psicológica, tendo em vista seu potencial, como enfatizado, para afetar todas as áreas da vida humana. Assim, dever-se-ia tentar ao máximo integrar as várias leituras (seja da enfermagem, da medicina, do serviço social, da psicologia etc.), de forma a fomentar a interdisciplinaridade. Assim, algumas ações seriam próprias apenas a uma ou outra disciplina específica (por exemplo, a revisão dos sistemas continuaria dependente essencialmente da expertise médica, de preferência, do clínico geral). No entanto, o mais importante não seria tanto o diagnóstico particular feito por uma disciplina isoladamente, mas a soma dos diagnósticos (do médico, do psicólogo, do assistente social etc.), que, de maneira aproximada, forneceria a 'biografia', a 'identidade', enfim, a territorialidade daquela 'existência-sofrimento'. A vantagem seria, no final, a construção de um projeto terapêutico menos 'formal' e efetivamente 'individualizado'.

\section{Apontamentos sobre Diagnóstico Interdisciplinar}

O diagnóstico médico, embora importante, é índice de apenas um dos aspectos da farmacodependência. Assim, para a construção de um projeto terapêutico consistente, é necessário um diagnóstico mais amplo, que permita à equipe de saúde não apenas individualizar as estratégias de cuidado mas também, em especial, construir um projeto terapêutico interdisciplinar e corresponsável, com a participação ativa do próprio utente e de seus familiares e amigos. O objetivo é estabelecer com o indivíduo a possibilidade de problematização de seu universo cultural e relacional, pois é por meio de sua identificação ou 
não identificação com os valores de sua territorialidade ${ }^{4}$ que se torna possível a autoconstrução da própria identidade.

Muitas vezes essas ligações territoriais estão de tal forma frágeis ou rompidas, em virtude dos transtornos inerentes à dependência química, que é grande a possibilidade de o indivíduo retornar ao comportamento compulsivo e autodestrutivo por absoluta falta de perspectiva. Assim, a função de um projeto terapêutico interdisciplinar é servir de mediador e guia para a problematização dessas relações, apresentando objetivos próprios ao pressuposto da atenção psicossocial de evitar a institucionalização e cuidar das condições para a autonomia individual.

Quando se utiliza o termo 'problematizar', o que se quer dizer é que a abordagem não pode ser baseada em um modelo que 'paternalize' as relações, despertando no indivíduo sentimentos de incapacidade, culpabilidade e insegurança. O objetivo não é gerar mais dependência; trata-se de evitar que o indivíduo procure um iluminado, um 'guru', um doutor, enfim, um 'salvador da pátria' do qual se sinta dependente para resolver seus problemas. Problematizar, aqui, significa colocar a própria dimensão do problema como o 'problema' a ser avaliado, antes que se pense em sua solução. Ou seja, supõe que se coloque em dúvida, em primeiro lugar, a própria pertinência do problema antes de, em segundo lugar, aceitá-lo como uma questão que mereça o esforço para a resposta adequada.

Sabe-se que as soluções podem ser falsas ou verdadeiras, mas o pior que pode advir é a solução 'verdadeira' para um falso problema. A solução 'verdadeira' para um falso problema eterniza o sofrimento causado pelo verdadeiro

\footnotetext{
4 Definimos territorialidade como sinônimo de mundo próprio. O termo territorialidade é utilizado pelos filósofos Gilles Deleuze e Felix Guattari. Ao se considerar a territorialidade, deixa-se de considerar o território como sinônimo de 'lugar' ou mesmo de 'espaço' e passa-se a considerá-lo como algo construído a partir de determinadas práticas humanas, que incluem as dimensões do saber, do poder e da subjetivação. Relações que são, portanto, econômicas, políticas e éticas, e não tão somente limitadas por considerações psicologistas ou biomédicas. A territorialidade é algo que se carrega consigo, que não é a terra propriamente, não é o espaço geográfico, é aquilo que poderíamos denominar, como antecipamos anteriormente - e conforme a etologia (Uexküll, s.d.) -, 'mundo próprio' (umwelt). E“mundo próprio"é um conceito que associa ambiente-organismo-afeto como singularidade, como sentido. Na dependência química, devemos entender melhor como os processos de produção de mundos próprios podem levar ou à legitimação do status quo (o que provavelmente fará essa subjetividade ser submetida pelas mesmas forças que a tornaram frágil e escravizada - submetida ao simbólico entendido como a regra geral hegemônica), ou à produção daquilo que Foucault (2004) chamou de subjetivação: a capacidade de ser diferente de si mesmo, de se autoproduzir, de ser, nesse sentido, livre das significações dominantes.
} 
problema não percebido e não resolvido (obscurecido pelo falso problema e sua solução verdadeira).

$\mathrm{O}$ 'modelo' ${ }^{5}$ da problematização propõe, então, estimular a capacidade do utente de, por si mesmo, levantar e avaliar os próprios problemas. Para tanto, é necessário quebrar a lógica pela qual a informação se concentra num único indivíduo, ou mesmo em uma equipe de saúde portadora de soluções. É necessário, antes, partilhar informações, exercitar um jogo no qual as crenças, preconceitos, estigmas e certezas (tanto dos membros da equipe quanto do utente, familiares e amigos) são postos em posição dialógica, até que a autonomia do utente seja (re)conquistada pela capacidade de se autoavaliar, de se autoconstituir como indivíduo produtor de suas próprias crenças e desejos, livre, enfim, tanto quanto possível, dos preconceitos, das superstições e dos falsos problemas. Com base nessa 'capacitação' ou 'empoderamento', torna-se desejável pensar na saúde como qualidade de vida, e não apenas como ausência de doença, conforme preconiza o Sistema Único de Saúde (SUS). É um engodo imaginar que uma equipe de saúde possa, por si mesma e sem a interação necessária e profunda com o utente, advogar qualquer prescrição, mudança de estilo de vida, ou seja lá o que for, em nome de uma pretensa 'qualidade de vida', que seria, nesse caso, sempre unilateral, estando, portanto, mais próxima de uma violência etnocêntrica ${ }^{6}$ do que de uma real promoção da saúde.

Nesse modelo problematizador, a função da equipe terapeuta é promover essa capacidade autopoiética, ${ }^{7}$ que por sua vez deve surgir no âmbito do próprio indivíduo ou grupo. Exercitar essa corresponsabilidade, na perspectiva do utente, não significa tão somente dividir os fracassos e os sucessos - de maneira que não haja culpados ou heróis -, mas também, e principalmente, ser livre para atuar sobre suas próprias condições de vida e modificá-las positivamente, mesmo que seja com a ajuda de equipe técnica especializada.

São também funções da equipe terapêutica: facilitar a construção de redes sociais solidárias de promoção da saúde como qualidade de vida; mobilizar os recursos da rede de atenção das comunidades (serviços residenciais

\footnotetext{
5 Não se trata propriamente de um modelo, mas de uma 'forma de pensar' que permite a variação caso a caso.

Crença na superioridade da cultura a que se pertence, acompanhada de sentimento de menosprezo por padrões de comportamento que se afastam da posição cultural do observador.

Termo introduzido pelos pesquisadores chilenos Humberto Maturana e Francisco Varela para designar o ser vivo enquanto ser 'autocriado' (Maturana \& Varela, 1980). Por extensão, designa, no homem, a capacidade de se autoinventar em termos físicos e cognitivos.
} 
terapêuticos, casas de passagens ou abrigos, grupos de ajuda mútua, comunidades terapêuticas, centros culturais e de convivência, oficinas terapêuticas, hospitais e clínicas etc.); e apoiar o desenvolvimento das competências dos indivíduos e das famílias.

A 'clínica da problematização' tem como objetivos, entre outros, reforçar a dinâmica interna (ou funcionamento interno) de cada indivíduo, para que este possa avaliar seus próprios valores, suas potencialidades e tornar-se o construtor de sua independência; reforçar a autoestima individual; redescobrir e reforçar a confiança em cada indivíduo diante de sua capacidade de evoluir e de se desenvolver como pessoa; problematizar o papel da família e da rede de relações que ela estabelece com o seu meio e valores culturais; prevenir e combater as situações de desintegração dos indivíduos e das famílias, e estimular a restauração e fortalecimento dos laços sociais; tornar possível a comunicação entre as diferentes formas do ‘saber popular' e 'saber científico'; estimular a participação social como requisito fundamental para dinamizar as relações sociais, promovendo a conscientização e estimulando o grupo, por meio do diálogo e da reflexão, a tomar iniciativas e ser agente de sua própria transformação.

O modelo coparticipativo e corresponsável proposto pela 'clínica da problematização' não inviabiliza abordagens clássicas, na medida em que procura respeitar a subjetividade (territorialidade) do indivíduo. Um cuidado que, no entanto, deve-se ter é evitar que determinadas abordagens (como, por exemplo, o messianismo dos 12 passos ou o psicanalismo) desempenhem um papel estruturante no serviço em desacordo com uma ética da atenção pública. Não se trata de proscrever a priori nenhuma abordagem possível (muito menos os 12 passos ou a psicanálise), mas absorvê-las como ferramentas úteis, retirando-lhes as características 'privatistas' (seja a religiosidade latente no exemplo dos 12 passos, seja a tendência a impor uma particular Weltanschauung, ${ }^{8}$ como às vezes acontece com a psicanálise) para que possam funcionar como utensílios que ora serão úteis, ora não, conforme a subjetividade em problematização.

Em suma, dependendo das demandas, são utilizadas as ferramentas possíveis, com o objetivo de melhorar a qualidade de vida e de acordo com o enfoque interdisciplinar citado, tais como a psicoterapia breve; psicoterapia em grupo; entrevista motivacional; psicanálise; psicologia analítica; atenção médica geral e psiquiátrica; atenção à família; e avaliação social.

\footnotetext{
8 Weltanschauung é uma palavra alemã que significa visão do mundo ou cosmovisão. Aqui utilizada no sentido de uma cosmovisão unilateralmente imposta.
} 


\section{Sugestão para a Construção de um Fluxograma de Atenção Interdisciplinar}

Como argumentado desde o início deste capítulo, na construção de estratégias de tratamento da farmacodependência, torna-se necessária uma visão complexa de cada caso, o que permite sua individualização, de maneira que, por um lado, não se possa estabelecer modelos fixos de ação, mas, por outro, em um sentido pragmático, seja possível dispor de determinadas prescrições, baseadas não apenas no conhecimento farmacológico básico a respeito de cada grupo de drogas e seus efeitos particulares na fisiologia humana, mas em um diagnóstico ampliado capaz de incluir a territorialidade e as singularidades de cada um.

Em parte, a construção do diagnóstico tanto impõe que se obtenha uma racionalidade geral de cada territorialidade quanto que se agreguem os fragmentos derivados dessas territorialidades, colhidos em diversas perspectivas (tanto do ponto de vista da clínica quanto na perspectiva epidemiológica ou da saúde pública, por exemplo). A forma de articulação desses fragmentos é a resultante das estratégias elaboradas pelas equipes territoriais conforme um diagnóstico situacional complexo (Acúrcio, Santos \& Ferreira, 1998). Dessa maneira, não há um modelo prefixado que determine a forma universal para todas as situações. Apenas pode-se exemplificar, de forma provisória e esquemática, uma sequência de acontecimentos que, a partir de uma territorialidade, possibilitam as ações estratégicas. Assim, sugerimos o seguinte esquema a ser seguido:

\section{Porta de entrada}

Nessa etapa são realizados o acolhimento e a avaliação clínica. O acolhimento visa primordialmente, pela escuta, à melhoria na qualidade da assistência, ao favorecer a relação usuário/trabalhador/serviço, e à ampliação das formas imediatas de intervenção individualizada.

As técnicas para o acolhimento variam de serviço para serviço, mas devem estar centradas, ao máximo, no utente, possibilitando o encaminhamento mais resolutivo da necessidade individual por meio de uma assistência acolhedora e humanizada. 
Em geral, o que se pretende no acolhimento é exatamente enfatizar a necessidade do próprio utente de participar de seu tratamento de maneira proativa e integral.

A emergência da territorialidade-sujeito é diretamente proporcional à subalternidade da doença e aos aparatos médico-biológicos e psicológicos de avaliação e conduta, que tradicionalmente objetificam a subjetividade, fragmentando-a em pedaços aos quais correspondem as disciplinas e especialidades. Essa fragmentação da subjetividade é proporcional à fragmentação do trabalho dos profissionais da saúde (Costa-Rosa, 2000).

Contudo, os maiores riscos são a negação da doença e a produção de subdiagnósticos. Resgatar a territorialidade-sujeito significa fazer emergir o vínculo clínico e crítico entre acontecimentos e sentidos vitais, e não simplesmente sobredeterminar o sentido em detrimento do acontecimento. Acontecimento e sentido estão ligados de forma irredutível, e produzir uma 'clínica do sujeito', usando o termo como em Campos (1997), mas invertendo os polos de atenção, do acontecimento (doença) para o sentido (sujeito), não significaria vantagem alguma em relação à clínica fragmentária dos modelos unicausais.

Os profissionais envolvidos no processo de acolhimento e avaliação clínica são o psicólogo, o assistente social e os cuidadores (técnicos de enfermagem e conselheiro). Para se evitar a 'ambulatorização' da acolhida, o médico (psiquiatra ou generalista) seria solicitado apenas para os casos de urgência/ emergência médica, ou conforme demanda situacional.

\section{Primeira fase: diagnóstico}

Nessa fase de diagnóstico, é realizada a coleta de elementos diagnósticos e aplicado um programa motivacional intensivo.

No exame do território, são realizados uma coleta de dados que permita a identificação e a hierarquização dos problemas e um inventário dos recursos do território relacionados aos três níveis de atenção sanitária, ou seja, a preventiva, a assistencial e a de promoção da qualidade de vida.

O diagnóstico situacional (avaliação de facilitadores e dificultadores 'ao tratamento') permite determinar a distribuição de um problema e suas causas, para racionalizar o planejamento de seu controle ou mitificar seus agravos. O conceito de diagnóstico situacional é proveniente das teorias sobre planejamento estratégico situacional, geralmente recomendado para equipes de saúde com atividades interdisciplinares e intersetoriais. É um instrumento que permite 
a identificação, descrição e análise de problemas atuais, a hierarquização dos problemas por ordem de prioridade, o planejamento conjunto de ações para a remissão total ou parcial desses problemas, o acompanhamento dos processos, o prognóstico e a avaliação dos resultados.

O planejamento das ações inclui a elaboração de planos de ação que visam essencialmente à reconstrução de horizontes vitais, sedutores do ponto de vista do utente, que possam substituir o prazer fácil das drogas. Obviamente, outras medidas mais simples devem ser observadas, visando à construção de redes de apoio que ofereçam o máximo de impacto (eficácia) com um mínimo de custo (eficiência), assegurando que as necessidades imediatas do utente sejam supridas com os maiores benefícios.

Como última etapa dessa fase, é aplicado um programa motivacional intensivo, cujo objetivo é estimular o tratamento e confeccionar um projeto terapêutico individualizado (territorializado).

\section{Segunda fase: tratamento}

Nessa fase de tratamento, a primeira etapa é a implementação das ações, na qual busca-se aplicar a tática escolhida, a mais apropriada, para viabilizar na prática o que foi planejado anteriormente, procurando motivar a participação ativa do utente. Em seguida, passa-se à aplicação do projeto terapêutico individualizado mediante ações complexas interdisciplinares.

\section{Terceira fase: manutenção}

Essa fase de manutenção depende, em parte, da demanda do utente, que pode requerer atenção continuada ou eventual, conforme a situação.

Trata-se de uma vigilância em saúde na qual há uma avaliação dos resultados das ações mediante o monitoramento dos objetivos alcançados pelo utente; é justamente nesse momento em que surge a flexibilização da estratégia com a possibilidade de correções ou a construção de nova estratégia.

\section{Instrumento-guia}

Atualizado e reatualizado constantemente durante o processo terapêutico (de preenchimento multiprofissional), os objetivos desse instrumento-guia são avaliar os componentes facilitadores e os dificultadores do tratamento, a fim de 
se construir táticas de viabilização que favoreçam positivamente o prognóstico e de se obter dados para uma intervenção individualizada (projeto terapêutico). É constituído por sete tópicos, discriminados a seguir.

\section{Perfil psiquiátrico e psicológico}

Para o diagnóstico de fatores médicos-psicológicos negativos (dificultadores) ao tratamento da dependência química, tais como síndromes psiquiátricas (psicóticas; fóbico-ansiosas; epiléticas; afetivas) ou transtorno de personalidade. Avaliação de possível comorbidade primária.

\section{Motivação}

Avaliação da motivação para o tratamento. Pode-se utilizar o clássico modelo de Rollnick e Miller (pré-contemplação, contemplação, determinação, ação).

De acordo com a avaliação, deve-se aplicar aconselhamento diretivo, centrado no utente, com o objetivo de estimular (motivar) o trabalho para uma mudança do comportamento.

\section{História do tipo de uso}

Tipo de droga/compulsão (tipos de substâncias usadas); droga de escolha (ou CID-10 F19); início de uso; frequência de uso.

\section{Grau de dependência}

Pode-se avaliar o grau de dependência, utilizando-se alguns critérios, a escolher. Como exemplo, o questionário Clinical Institute Withdrawal Assesment for Alcohol (CIWA) para alcoolistas e o teste de Fagestrom para os casos de tabagismo.

\section{Características do contexto social relativo à rede de apoio}

A rede de apoio pode ser inexistente (pede-se que seja citado o motivo, se houver); existente (pede-se que sejam citados quais os tipos); e possível (pedese que seja explicado).

O contexto de vida social pode ser facilitador ou não do tratamento, dependendo de determinados fatores, tais como harmonia ou desagregação familiar, presença ou ausência de vínculo empregatício, grau de envolvimento com o tráfico de drogas etc. Dessa maneira, pede-se que tais indicadores sejam avaliados como importantes no projeto terapêutico imediato, como também para as abordagens psicossociais disponíveis a posteriori. 


\section{Cultura de uso}

Se vinculado ao trabalho (happy hour, por exemplo), ao tráfico, ao sexo etc.

\section{Problemas associados}

Encaminhamento judicial; processos criminais, prisões, dívidas com tráfico, busca de refúgio etc.

\section{Abordagem para redução de riscos e danos}

Durante o tratamento, pode ser feito um treinamento psicoeducativo em situações de risco, situações sociais geradoras de ansiedade e estresse etc.

Não se deve imaginar que a redução de danos seja, como ideologicamente se acusa, uma lógica que incite ao uso de drogas. Pelo contrário, essa estratégia baseia-se em dados da realidade, que vêm exatamente dos centros de tratamento que privilegiam unicamente a abstinência total e que são incapazes, em sua totalidade, de atingir um índice de abstinência superior a 30\%. Ou seja, 70\% dos dependentes químicos ou se institucionalizam em situações de revolving door, entrando e saindo, num ciclo intermitente de internações não resolutivas, ou são abandonados ou capturados pelos aparelhos de repressão, situação que gera muita dor e sofrimento, sobretudo pelo estigma da criminalização, e que pode levá-los até mesmo à morte. Contudo, não se deve acreditar que a redução de danos, como política pública, estabeleça para a assistência qualquer prescrição que inviabilize estratégias que visem à abstinência. Da mesma forma, uma política de redução de danos não inviabilizaria, sem ser contraditória, qualquer abordagem racional que vise à proteção do utente, como, por exemplo, uma internação de curta ou média permanência.

Enfim, uma política de redução de danos é apenas indicativa para ações públicas flexíveis que minimizem as consequências das más relações com as drogas que as pessoas eventualmente produzem. Tais relações, hoje em dia, derivam justamente da maneira como as drogas são tratadas pelas determinações do Estado.

\section{Conclusão}

Um dos motivos para o fracasso dos tratamentos para a dependência química é a dificuldade para a reconstituição, por parte do próprio utente, de uma 
rede de apoio social e familiar adequada em sua comunidade. A capacidade de construção de um horizonte de vida que seja mais sedutor que o prazer fácil das drogas também é essencial. Por isso, a simples aquisição de um certo controle sobre o comportamento compulsivo de uso de substâncias químicas (que muitas pessoas confundem com 'redução de danos') não significa a extinção do chamado problema-drogas na vida da maioria dos utentes.

Pode-se entender o problema-drogas de várias maneiras, desde os conflitos intrapsíquicos provocados pelas perdas emocionais ou pelos problemas econômicos gerados por perdas materiais até as mazelas geradas pelo estigma, pelos conflitos com a lei e a polícia, pelas ligações com a criminalidade etc.

Em alguns casos, o utente é real portador de comorbidade psiquiátrica primária, e as dificuldades para o autorreconhecimento do problema (o chamado juízo crítico da morbidade) pode levar à recidiva do comportamento abusivo e/ ou patológico.

A clínica da problematização deve também levar em consideração ações preventivas para se evitar as condições de recidiva. Observa-se, então, uma abertura e uma flexibilidade do serviço com a finalidade de facilitar que o utente possa continuar recebendo suporte e cuidado, de maneira que sua conduta (ou comportamento) se determine por um modo autônomo, ético e racional.

\section{Referências}

ACÚRCIO, F. A.; SANTOS, M. A. \& FERREIRA, S. M. G. O planejamento local de serviços de saúde. In: MENDES, E. V. (Org.). A Organização da Saúde no Nível Local. São Paulo: Hucitec, 1998.

BELMONTE, P. História da Homossexualidade: ciência e contra-ciência no Rio de Janeiro (1970-2000), 2009. Tese de Doutorado, Rio de Janeiro: Fundação Oswaldo Cruz, Casa de Oswaldo Cruz.

CAMARGO JR., K. R. As armadilhas da 'concepção positiva de saúde'. Physis, 17(1): 63-76, jan.-abr. 2007.

CAMPOS, G. W. S. A Clínica do Sujeito: por uma clínica reformulada e ampliada. Campinas: Universidade Estadual de Campinas, 1997. (Mimeo.)

CARLINI E. A et al. I Levantamento Domiciliar sobre o Uso de Drogas Psicotrópicas no Brasil. São Paulo: Centro Brasileiro de Informações sobre Drogas Psicotrópicas da Universidade Federal de São Paulo (Cebrid/Unifesp), Secretaria Nacional Antidrogas (Senad), 2001. 
COSTA-ROSA, A. O modo psicossocial: um paradigma das práticas substitutivas ao modo asilar. In: AMARANTE, P. (Org.). Ensaios: subjetividade, saúde mental, sociedade. Rio de Janeiro: Editora Fiocruz, 2000.

DSM-IV. Manual Diagnóstico e Estatístico de Transtornos Mentais. Porto Alegre: Artes Médicas, 1995.

FOUCAULT, M. A ética do cuidado de si como prática da liberdade. In: FOUCAULT, M. Ética, Sexualidade e Política. Rio de Janeiro: Forense Universitária, 2004.

FRANCES, A.; WIDIGER, T. \& FYER, M. R. The influence of classification methods on comorbity. In: MASERJ. D. \& CLONINGER, C. R. (Orgs.). Comorbity of mood and anxiey disorders. Washington D. C.:American Psychiatry Press, 1990.

LEAVELL, H. \& ClARK, E. G. Medicina Preventiva. São Paulo: McGraw-Hill do Brasil, 1976.

MATURANA, R. H. \& VARELA, F J. Autopoiesis and Cognition: the realization of the living. Dordrecht: D. Reidel Publishing Company, 1980.

ORGANIZAÇÃO MUNDIAL DA SAÚDE (OMS). Relatório sobre Saúde no Mundo: saúde mental - nova concepção, nova esperança. Genebra: OMS, 2001.

ORGANIZAÇÃO MUNDIAL DA SAÚDE (OMS). Relatório Mundial - Organização Mundial da Saúde. Genebra: OMS, 2003.

ROTELLI, F. Onde está o Senhor? In: LANCETTI, A. (Org.). Saúde e Loucura 3, São Paulo: Hucitec, 1991.

UEXKÜLL, J. Dos Animais e dos Homens. Lisboa: Livros do Brasil, s.d.

WORLD HEALTH ORGANIZATION (WHO). The ICD-10 Classification of Mental and Behavioural Disorders: clinical descriptions and diagnostic guidelines. Geneva:World Health Organization, 1992. 


\title{
Rastreamento e Abordagem Terapêutica de Doentes com Problemas Relacionados ao Álcool
}

\author{
Fátima Guedes
}

O consumo regular de bebidas alcoólicas integra os hábitos e a cultura de fração substancial da população dos países ocidentais, e os problemas relacionados com esse consumo têm ocupado espaço de relevo na esfera da saúde, ao longo da história da humanidade, constituindo-se em causa importante de várias patologias orgânicas, dentre as quais a doença hepática alcoólica ganha destaque, já que o fígado representa o principal local de metabolização do álcool e, portanto, é alvo principal da toxicidade alcoólica.

Os mecanismos de agressão hepática englobam aqueles que resultam dos próprios efeitos metabólicos, múltiplas alterações, tanto da imunidade humoral, como da imunidade mediada por células, sobretudo mediante a agressão por linfócitos T, com importante participação de citoquinas como mediadores da agressão hepatocitária. Assim, o espectro clínico dessa agressão envolve a esteatose hepática, hepatite alcoólica, fibrose hepática e cirrose hepática, com potencial evolutivo para o desenvolvimento do carcinoma hepatocelular (Liskow et al., 1995).

A metabolização hepática do álcool ocorre em três vertentes: a álcooldesidrogenase no citosol, o sistema microssomal no retículo endoplasmático liso e a catalase nos peroxissomas. A participação dessas vias metabólicas se dá em função da quantidade de consumo, verificando-se, ainda, uma proporcionalidade entre os efeitos tóxicos e a dose consumida (Lieber, 1995; Liskow et al., 1995). 


\section{Padrões de Consumo de Álcool: consumo excessivo e dependência alcoólica}

Tendo-se em conta que na categoria de referência, os abstêmios, são pessoas que não consomem álcool, os padrões de consumo alcoólico são definidos para distinguir os níveis que caracterizam o 'beber moderado' ou de 'baixo risco' e o 'uso prejudicial' ou de 'alto risco', tomando por base os riscos para a saúde (O’Malley et al., 1995).

De acordo com a Organização Mundial da Saúde (OMS), o consumo de baixo risco corresponde até uma dose por dia, para a mulher e para o indivíduo com idade superior a 65 anos, e até duas doses por dia para o homem, considerando-se $180 \mathrm{ml}$ de vinho, $360 \mathrm{ml}$ de cerveja ou $45 \mathrm{ml}$ de bebidas destiladas como uma dose padrão contendo cerca de 12 gramas de álcool. O consumo prejudicial ou de alto risco corresponde, no homem, a mais de 14 doses por semana ou mais de quatro doses por ocasião, e, na mulher, a mais de sete doses por semana ou mais de três doses por ocasião (O’Malley et al., 1995).

A ocorrência de diversas isoenzimas, sobretudo a álcool-desidrogenase, pode conferir um certo determinismo genético na susceptibilidade individual para o desenvolvimento da doença alcoólica e suas complicações orgânicas. Isso pode explicar o fato de que, por um lado, o consumo de álcool, mesmo em doses excessivas, não determina, necessariamente, o comprometimento orgânico, havendo um número de bebedores sem qualquer manifestação orgânica de significado patológico; e, por outro lado, a maioria de consumidores que apresentam sérios problemas relacionados ao álcool, quer decorrentes de consumo excessivo ocasional, quer resultantes de consumo prolongado, podem ou não atender aos critérios diagnósticos de dependência alcoólica, mas que determinam graves consequências clínicas, sociais e econômicas que impõem a necessidade de abordagem terapêutica adequada (Lieber, 1995; Liskow et al., 1995).

Os critérios diagnósticos definidos, e mais comumente aceitos, para a síndrome de dependência alcoólica envolvem a presença, no paciente - considerando-se um período de 12 meses -, de três ou mais das seguintes alterações: tolerância; recidivismo; ingestão de maiores quantidades ou persistência da ingestão por mais tempo que o desejado; desejo permanente de beber ou esforços sem sucesso de reduzir ou controlar a ingestão; abandono de importantes atividades profissionais ou sociais em virtude do consumo de álcool; e, ainda, a 
continuidade no consumo de bebidas alcoólicas apesar de ter conhecimento de que tem um problema persistente ou recorrente, de natureza física ou psicológica, em virtude do uso (Kristenson \& Trell, 1982; O'Malley et al., 1995; Wilson \&Vulcano, 1985).

\section{Diagnóstico dos Problemas Ligados ao Álcool}

A despeito da alta prevalência de problemas relacionados ao álcool, somente um percentual de 24 a 30\% dos doentes afetados por essas complicações são identificados (sendo essa proporção ainda menor entre as mulheres), e muitos apenas quando apresentam complicações orgânicas graves. Com isso, o subdiagnóstico e o tratamento inadequado são bastante comuns (Babor \& Grant, 1992; Bien, Miller \& Tonigan, 1993; Edwards, Orford \& Egert, 1977; Fletcher, Fletcher \& Wagner, 1996).

Levando-se em consideração a elevada prevalência, a gravidade dos problemas e o elevado custo médico-social da doença alcoólica, era de se esperar que essa condição patológica constituísse uma prioridade na educação formal dos profissionais da saúde, e, portanto, o tratamento dirigido aos problemas relacionados com o álcool se mostrasse prioritário, o que não tem sido verificado (Deitz et al., 1994). O que se tem observado são índices diagnósticos baixos, que podem representar uma certa negligência quanto à detecção desses transtornos e uma hesitação quanto à intervenção terapêutica, quer por falta de conhecimentos, quer por estigmatização ou preconceito, quer por pessimismo quanto à probabilidade de sucesso na recuperação do doente alcoólico.

Nesse contexto, tem sido crescente, no âmbito da educação médica, a preocupação de que seja recomendado, pelo menos para algumas especialidades básicas - como clínica geral e medicina geral e familiar, medicina interna,pediatria e ginecologia e obstetrícia -, treinamento especial com o objetivo de desenvolver as habilidades necessárias para rastrear e diagnosticar, implementar intervenções terapêuticas iniciais e encaminhar os doentes às voltas com problemas com o álcool para serviços especializados, buscando, desse modo, capacitar os profissionais a intervirem precoce e eficazmente e, assim, darem resposta efetiva aos problemas relacionados ao consumo de álcool e outras drogas. Dessa forma, é importante reafirmar a importância da triagem rotineira e da intervenção terapêutica no âmbito dos programas de atenção à saúde, tanto ao nível de atenção primária como secundária e terciária. 
Há dados consistentes na literatura quanto à eficácia do tratamento que indicam a redução da demanda dos serviços de assistência à saúde e do custo médico-social relacionados a problemas que envolvem o consumo de álcool. Para isso, é necessário que os profissionais da saúde, nomeadamente os médicos, procedam a triagem de todos os doentes com problemas relacionados ao consumo de álcool, avaliem os problemas a ele associados e sintomas de abstinência, adotem estratégias terapêuticas adequadas, encaminhem, quando necessário, os pacientes para programas especializados ou para grupos de ajuda mútua, proporcionem assistência aos familiares envolvidos, identificando a codependência, o que proporcionará, portanto, uma compreensão mais clara sobre a dinâmica da sua interação com o doente (Anton \& Becker, 1995; Bien, Miller \& Tonigan, 1993; Edwards, Orford \& Egert, 1977).

\section{Triagem dos Indivíduos com Problemas Associados ao Álcool}

É importante considerar que a maioria dos doentes procuram assistência médica por conta das alterações orgânicas decorrentes do uso continuado e excessivo, o que favorece a não detecção desse consumo. Muito embora a fonte mais valiosa de informação concernente ao uso de álcool seja a história do paciente, que envolve igualmente a história familiar e o padrão de consumo (que subsidiaria a distinção entre o consumo de baixo e alto risco), a informação do paciente a respeito da quantidade consumida não constitui critério principal para diagnosticar o abuso do álcool, visto que o consumo referido pode não ser confiável, e existe ainda a suscetibilidade individual. Assim, um mesmo padrão de consumo pode produzir efeitos variáveis em diferentes indivíduos, com consequências diversas. Do mesmo modo, os problemas observados podem não ter relação direta com o consumo de álcool.

\section{Estratégias de triagem}

A triagem (screening) dos problemas associados ao álcool pode ser facilitada pelo uso de instrumentos específicos, como os vários questionários utilizados para esse propósito, avaliados quanto à sensibilidade e especificidade que apresentam. Contudo, nenhum questionário é mais eficaz do que o outro, seja no âmbito da população em geral, ou em grupos específicos (adolescentes, minorias étnicas e raciais, idosos e grávidas), bem como a maioria falha por não 
diferenciar os distúrbios atuais dos pregressos (Babor \& Grant, 1992; Bohn, Babor \& Kranzler, 1995; Chan et al., 1993; Cleary et al., 1988; Deitz et al., 1994; Ewing, 1984; Fleming \& Barry, 1991; Lundwall \& Baekeland, 1971).

\section{Questionários}

Numa avaliação pormenorizada, consideramos os questionários Audit, Cage e o Cage modificado (Tweak) como aqueles de melhor confiabilidade e consistência (Bohn, Babor \& Kranzler, 1995; Cleary et al., 1988; Ewing, 1984; Fleming \& Barry, 1991).

O Alcohol Use Disorders Identification Test (Audit) avalia o consumo, o comportamento alcoólico e as complicações decorrentes do uso de álcool ao longo dos últimos 12 meses, com ênfase nos distúrbios atuais. Consta de dez perguntas, com valores de 0 a 4 , apresentando escores totais que variam de $0 \mathrm{a}$ 40.Um escore superior a 8 é sugerido como limite para a avaliação subsequente. Apresenta uma sensibilidade bastante variável (38-63\%) e uma especificidade razoavelmente elevada (95-96\%) (Bohn, Babor \& Kranzler, 1995).

O Cut, Annoyed, Guilty, Eye-openned (Cage) contém apenas quatro perguntas, e duas ou mais respostas afirmativas sugerem positividade. Apresenta uma sensibilidade que varia de 43 a 100\% e uma especificidade de 68 a 96\%, ressaltando-se que variações sutis na forma como é aplicado podem alterar significativamente os índices de resposta. Além disso, não é tempo-sensível, portanto, não diferencia problemas atuais de pregressos. A despeito dessas restrições, é um teste amplamente utilizado em virtude de sua facilidade de aplicação (Ewing, 1984).

Recentemente, houve uma modificação do Cage com o intuito de melhorar seu desempenho. Essa modificação resultou no teste Tweak, que inclui duas questões do Cage e acrescenta três outras questões que avaliam a tolerância, a culpa com relação ao passado e alterações cognitivas no tocante à memória (Ewing, 1984; Fleming \& Barry, 1991).

A escolha de um teste deve ter por base sua aceitação pelos doentes e pelos próprios profissionais da saúde, a facilidade de aplicação e o grau de confiabilidade dos seus resultados.

Assim, o Cage, de fácil aplicação e com desempenho relativamente satisfatório, associado a itens relativos à quantidade-frequência de uso, tem sido recomendado pelo National Institute on Alcohol Abuse and Alcoholism (NIAAA), dos Estados Unidos, na perspectiva da sua utilização rotineira e por detectar, provavelmente, a maioria dos indivíduos com problemas relacionados ao álcool 
atendidos na prática clínica, fornecendo, ainda, subsídios antes de se prescreverem medicamentos que interagem com o álcool (O’Malley, 1995).

\section{Marcadores sorológicos: testes laboratoriais}

Vários testes laboratoriais têm sido estudados como marcadores biológicos do consumo excessivo de álcool. A dosagem sérica da gama glutamil transferase (GGT) e da aspartato amino transferase (AST), antes denominada transaminase glutâmico-oxalacética (TGO), e a avaliação do volume globular médio (VGM) constituem os marcadores biológicos mais estudados. Considerando-se a sensibilidade e a especificidade, tem-se verificado que a GGT apresenta 60$90 \%$ e $55-100 \%$, respectivamente. A mesma avaliação para a AST revela uma sensibilidade de $35-50 \%$ e uma especificidade maior que $90 \%$, enquanto o VGM mostra sensibilidade de 40-50\% com 64-100\% de especificidade (Kristenson \& Trell, 1982; Lieber, 1995).

A transferrina deficiente em carboidratos, isoformas da transferrina deficientes em ácido siálico (CDT), tem sido amplamente estudada, e seus níveis séricos têm sido associados à detecção e monitorização do consumo crônico de álcool, com razoável sensibilidade (70 a 80\%) e elevada especificidade (90 a 95\%).A despeito de estudos que questionam sua eficácia diagnóstica,é considerada, por muitos autores, como o marcador biológico acessível mais apropriado na discriminação do consumo persistente de álcool (Lieber, 1980).

Cabe enfatizar que, de um modo geral, nenhum teste laboratorial é tão sensível ou específico quanto os questionários, ressaltando-se que esses testes são mais acurados quanto à detecção da dependência alcoólica. Assim, o uso rotineiro dos marcadores serológicos só é recomendável para os indivíduos sintomáticos e para questionários positivos.

A Figura 1 apresenta o que desenvolvemos para a abordagem na triagem dos indivíduos com problemas associados ao álcool. 
Figura 1 - Algoritmo de abordagem de rastreamento dos indivíduos com problemas relacionados ao álcool

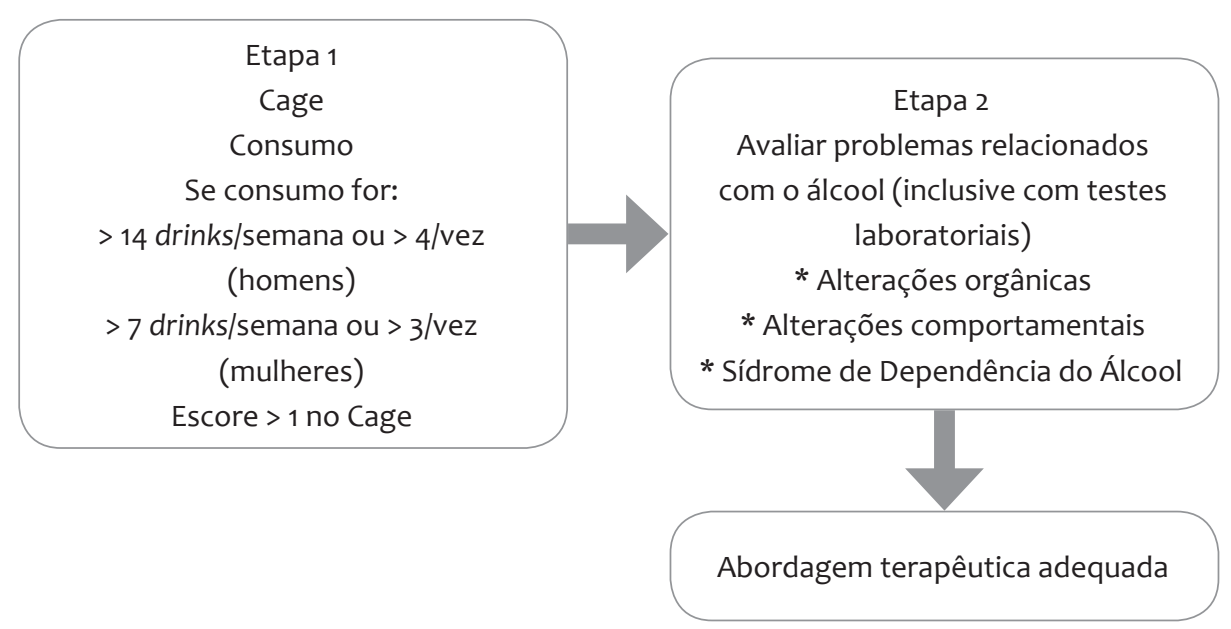

\section{Abordagem Terapêutica}

Na perspectiva de busca da abordagem terapêutica adequada, faz-se necessário o conhecimento detalhado da história natural da doença alcoólica. É sabido que, além da heterogeneidade do comportamento alcoólico, a evolução da doença alcoólica é extremamente variável e depende de uma série de fatores que compreendem o determinismo genético e a suscetibilidade individual, além dos fatores relativos ao meio, de natureza social ou familiar (Wilson \& Vulcano, 1985).

Estudos multicêntricos internacionais têm revelado que o início do consumo de álcool tem sido cada vez mais precoce já na adolescência; entretanto, em alguns países esse consumo se dá em uma faixa etária mais alta, entre os 20 e 30 anos de idade. A não ser em formas bastante particulares em que o agravamento se dá de maneira muito acelerada, a evolução é quase sempre insidiosa. Nessa evolução, lenta e progressiva, observa-se o fenômeno da tolerância, caracterizado pela diminuição de resposta à dose consumida que ocorre com o uso continuado do álcool, visto tratar-se de um efeito da ação de um indutor enzimático que determina o aumento da taxa de metabolização e, com isso,sua eliminação mais rápida (Lieber, 1995; Wilson \& Vulcano, 1985).

Com a manutenção do consumo nesses moldes, a dependência alcoólica pode vir a instalar-se entre os 30 e 40 anos (Figura 2). É importante referir que, 
com a exposição cada vez maior e prolongada aos efeitos tóxicos do álcool, os danos orgânicos são inevitáveis, nomeadamente o dano hepático, com prejuízo da metabolização, o que leva ao desenvolvimento da denominada tolerância reversa, também denominada sensibilização, traduzida pela hipersusceptibilidade do organismo na qual a resposta ao álcool é aumentada com o uso repetido, observando-se efeitos maiores com doses menores (Wilson \& Vulcano, 1985).

Figura 2 - Curva de tolerância e tolerância reversa (sensibilização) na evolução da doença alcoólica

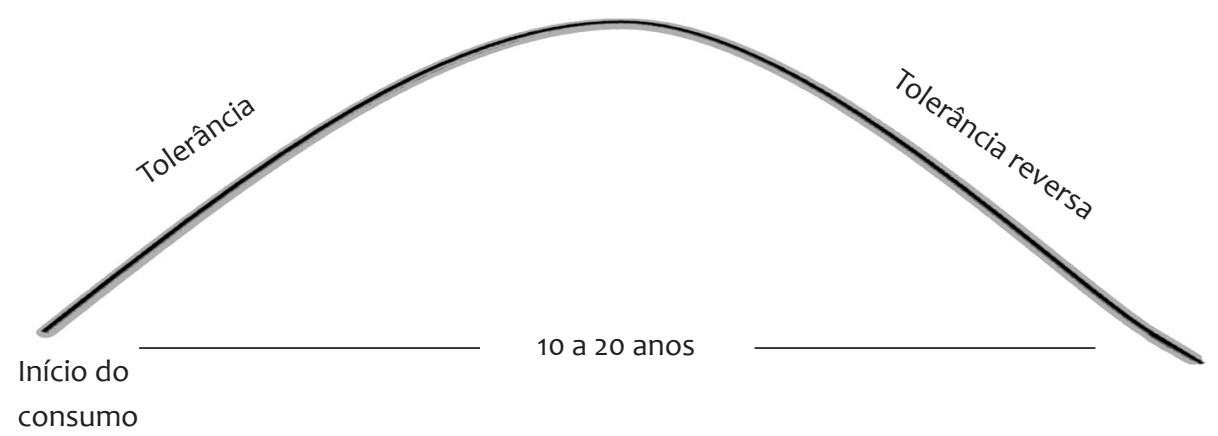

Embora seja considerada, via de regra, inevitável e desfavorável, a evolução natural pode, ao contrário, mostrar remissão espontânea, ou seja, cessação do consumo excessivo de álcool sem qualquer ajuda terapêutica ou mesmo de grupos de ajuda mútua.

A evolução, desde o início do consumo até o desenvolvimento da dependência alcoólica, se dá, habitualmente, dentro de um período mais ou menos longo, em média, de 10 a 20 anos, ao longo do qual o paciente apresenta um consumo excessivo, sem contudo estar dependente do álcool (Wilson \&Vulcano, 1985).

A precocidade ou não do aparecimento do consumo excessivo, bem como a velocidade com que se instala a dependência, a sua evolução e o prognóstico, dependem de predisposições biológicas e patologias associadas, que caracterizam as formas clínicas da doença alcoólica. 


\section{Abordagem Terapêutica Adequada}

Dentre os pressupostos de uma abordagem terapêutica adequada devem estar incluídos o estabelecimento e a manutenção de uma aliança terapêutica; a monitorização clínica do estado do doente; o diagnóstico e o tratamento das comorbidades eventuais; o tratamento da intoxicação alcoólica e da síndrome de abstinência; o desenvolvimento e a facilitação da aderência ao plano terapêutico; a prevenção de recaídas; a redução da morbidade, das complicações e das mortalidades e, com isso, a redução do elevado custo médico-social da doença alcoólica (O’Malley et al., 1995).

Assim, uma abordagem terapêutica adequada deve envolver tanto o tratamento farmacológico dos problemas associados ao álcool como um processo terapêutico que desencadeie a modificação comportamental necessária para a recuperação do paciente.

\section{Tratamento farmacológico dos problemas relacionados ao álcool}

No tratamento farmacológico dos problemas relacionados ao álcool, devem estar inseridos alguns objetivos fundamentais, que compreendem o tratamento da dependência e a reversão dos efeitos metabólicos do álcool, o tratamento e a prevenção das manifestações clínicas e complicações da síndrome de abstinência alcoólica, a manutenção da abstinência e a prevenção de recaídas e o tratamento das manifestações orgânicas associadas, bem como distúrbios decorrentes de comorbidade psiquiátrica que possam interferir no processo de recuperação.

\section{Tratamento farmacológico da dependência alcoólica}

O tratamento farmacológico da doença alcoólica, ao longo de várias décadas, restringia-se à intervenção na síndrome de abstinência, sendo os medicamentos de sensibilização ao álcool a única opção para diminuir a dependência. Nesses últimos vinte anos, outros medicamentos surgiram no cenário da farmacoterapia da doença alcoólica, ressaltando-se, entre outros, os antagonistas opioides, nomeadamente a naltrexona, o acamprosato e, mais recentemente, o topiramato (Anton \& Becker, 1995; Besson, 1997; Wilson \& Vulcano, 1985). Esses medicamentos destinam-se, por um lado, à prevenção ou 
redução das manifestações da síndrome de abstinência alcoólica e, por outro, à redução da fissura (craving) provocada pelo álcool, auxiliando, com isso, a prevenção de recaídas.

Dentre os medicamentos disponíveis assinalados, ressaltam-se os aversivos ou sensibilizantes ao álcool, os antagonistas opioides, o acamprosato e o topiramato.

Os medicamentos aversivos ou sensibilizantes ao álcool são administrados com o objetivo de ajudar o paciente a manter a abstinência. Nesse grupo de medicamentos estão incluídos o dissulfiram e a carbimida de cálcio (esse último disponível apenas no Canadá). São medicamentos cujo mecanismo de ação, na presença do álcool, consiste na inibição irreversível e inespecífica da enzima acetaldeído-desidrogenase (ALDH), com consequente acúmulo de acetaldeído no organismo, levando à reação etanol-dissulfiram. Se houver ingestão de álcool, ocorrerá um aumento dos níveis de acetaldeído, determinando uma reação de aversão caracterizada por rubor facial, cefaleia pulsátil, náuseas e vômitos, dor torácica, taquicardia, palpitações, fraqueza, sonolência, visão turva, confusão mental e hipotensão, que, em indivíduos suscetíveis, podem desencadear reações graves, com arritmia cardíaca, depressão respiratória, convulsões e morte.

Esses medicamentos possuem um leque amplo de contraindicações, ocorrendo ainda importantes interações medicamentosas, sobretudo com warfarina, fenitoína, isoniazida, rifampicina, diazepam, clordiazepóxido, imipramina e desipramina, causadas pela interferência na biotransformação dos mesmos, resultando em níveis tóxicos. Sob tratamento com esses medicamentos, os doentes devem ser alertados sobre os riscos de toda e qualquer ingestão ou utilização de álcool, inclusive soluções de higiene oral e vinagre.Essa classe de medicamentos parece atuar sobretudo a partir do reconhecimento psicológico da interacção potencial com o álcool, não tendo nenhum efeito primário sobre o craving ou a urgência de beber (Anton \& Becker, 1995; Besson, 1997; Miller \& Rollnick, 1991).

Os antagonistas opioides são medicamentos cujo mecanismo de ação consiste na inibição da liberação de dopamina nas fendas sinápticas do núcleo acumbens, o que tem como consequência a diminuição dos efeitos prazerosos e sedativos do álcool. Esses efeitos prazerosos resultam, por um lado, da atividade excitatória dos peptídeos endógenos (encefalinas e b-endorfinas), mediada pela liberação da dopamina. Por outro lado, parece haver uma ação inibitória dos peptídeos endógenos sobre os interneurônios gabaérgicos, localizados na área tegmental ventral, que exercem efeitos inibitórios sobre os neurônios dopaminérgicos. 
A administração de antagonistas opioides reduz o consumo de álcool mediante o bloqueio pós-sináptico dos receptores opioides. Assim, a naltrexona, medicamento característico da classe dos antagonistas opioides, atua como um antagonista competitivo nos receptores opioides e, com isso, parece atenuar os efeitos reforçadores do consumo de álcool e reduzir o desejo compulsivo de beber, ainda que apresentando alguns efeitos colaterais importantes, sobretudo como potencial hepatotoxina dose-dependente e interação medicamentosa com a tioridazina (Anton \& Becker, 1995; Besson, 1997; Miller \& Rollnick, 1991).

O acamprosato (honotaurinato de cálcio) possui efeitos que envolvem a inibição da atividade excitatória glutamatérgica, agindo, provavelmente, em uma subclasse dos receptores de glutamato (NMDA), em especial, quando há hiperatividade desses receptores. Por sua vez, esses receptores parecem modular a atividade dopaminérgica no núcleo acumbens, reduzindo o reforço positivo associado ao consumo de etanol. Estudos revelam que o acamprosato, além de auxiliar na imediata interrupção do consumo de álcool, contribui para a manutenção da abstinência. Dentre os seus efeitos colaterais, ressaltam-se a diarreia e a cefaleia, devendo-se, ainda, ter bastante precaução quanto à sua indicação em doentes com insuficiência renal, visto que sua eliminação é feita pelos rins (Anton \& Becker, 1995; Besson, 1997).

O topiramato é um antagonista de uma subclasse de receptores do glutamato (Ampa), cujos efeitos parecem residir na redução do reforço positivo associado ao consumo de álcool. Estudos têm demonstrado a eficácia terapêutica desse medicamento, representada pela redução do craving, dos níveis séricos de gamaglutamil transferase, e pelo aumento das taxas de abstinência (Anton \& Becker, 1995; Besson, 1977).

Esses medicamentos (dissulfiram, naltrexone, acamprosato e topiramato) são considerados de grande valia terapêutica, visto que auxiliam a obtenção da abstinência e a prevenção das recaídas, devendo, no entanto, ser utilizados como parte de um programa global que inclua intervenção terapêutica de orientação para a mudança comportamental.

Cabe ressaltar que, no contexto do tratamento da doença alcoólica, fazse mister a abordagem terapêutica medicamentosa da síndrome de abstinência alcoólica (SAA), que acomete cerca de 13 a 71\% dos doentes alcoólicos, com manifestações mais ou menos graves. Os objetivos do tratamento devem ser direcionados com o intuito de minimizar os distúrbios fisiológicos, inibir o surgimento de sinais e sintomas mais graves, tais como crises convulsivas e delirium tremens, bem como estimular o início da reabilitação da doença 
alcoólica (Anton \& Becker, 1995; Besson, 1977; Chu, 1979; Kaim, Klett \& Rothfeld, 1969; Vaillant, 1983).

Um amplo leque de psicofármacos tem sido utilizado no tratamento da SAA. Os benzodiazepínicos (BDZ) ainda ocupam espaço de relevo, porém, apesar da eficácia dos mesmos, existem inúmeras referências que indicam o potencial abuso dos BDZ por ocasião da detoxificação alcoólica, bem como ressaltam os importantes e graves efeitos colaterais (Anton \& Becker, 1995; Besson, 1977; Vaillant, 1983).

Dentre outros medicamentos, a tiaprida tem sido utilizada. Trata-se de um medicamento cujo mecanismo de ação reside no fato de ser um neuroléptico que bloqueia os efeitos estimulantes do etanol e interfere no efeito reforçador do álcool, sendo bem tolerado por ter uma atividade depressora pequena e por não interagir com os efeitos depressores do etanol, cuja eficácia reside em prevenir o desenvolvimento de formas graves da SAA (Anton \& Becker, 1995; Besson, 1977).

Os anticonvulsivantes, especialmente a carbamazepina e a oxicarbamazepina, têm larga utilização na prevenção e tratamento das possíveis crises convulsivas que integram o elenco de sintomas da SAA (Anton \& Becker, 1995; Besson, 1977; Chu, 1979; Vaillant, 1983).

Além destes, a administração de tiamina é quase consensual para prevenir complicações da SAA, sobretudo a encefalopatia de Wernicke e a síndrome de Korsakoff. Do mesmo modo, a reposição de magnésio mostra-se importante, visto que a hipomagnesemia é bastante comum em doentes alcoólicos que interrompem o consumo, apresentando sinais e sintomas que, embora inespecíficos, incluem, via de regra, reflexos hiperativos, tremores, fraqueza, hipoparatireoidismo com hipocalcemia e hipopotassemia refratária, podendo, também, evoluir para arritmias cardíacas.( Anton \& Becker, 1995; Besson, 1977; Liskow et al., 1995; Vaillant, 1983).

A despeito de a farmacoterapia da doença alcoólica desempenhar um papel importante e muitas vezes primordial no auxílio aos doentes, buscando interromper, com segurança, o consumo do álcool, é importante considerar que o tratamento farmacológico é apenas um elemento da abordagem terapêutica dos doentes. Um elemento importante, sem dúvida, visto que contribui para o desenvolvimento de um ambiente calmo, produz uma confiança renovada e permite uma reavaliação contínua e a correção de distúrbios associados, mas que deve se fazer acompanhar de outras intervenções terapêuticas que favoreçam a prevenção de recaídas e que atuem junto aos fatores psicossociais que 
integram a etiopatogenia da doença alcoólica.Portanto,várias metodologias têm sido utilizadas. Nessas três últimas décadas, inúmeros estudos indicam a eficácia das intervenções breves, realizadas tanto por profissionais médicos como por outros profissionais da saúde, sobretudo naqueles pacientes que apresentem complicações mais graves, com relatos de taxas de abstinência superiores a 80\%, considerando um período de cinco anos (Bien, Miller \& Tonigan, 1993; Edwards, Orford \& Egert, 1977; Miller \& Sovreign, 1989; NIAAA, 1995; O'Malley et al., 1995; Turner et al., 1989).

Considerando-se que o sucesso terapêutico da doença alcoólica, como de qualquer outra forma de dependência e mesmo de outras patologias crônicas, depende em grande parte da modificação comportamental, e que o processo de modificação de qualquer comportamento exige um tempo razoavelmente longo, as intervenções breves podem funcionar como um catalisador da mudança comportamental necessária.

De acordo com estudos da OMS, as intervenções breves, além de eficazes, podem ser aplicadas às diversas condições culturais e situações de atenção à saúde (Turner et al., 1989).

\section{Intervenções Breves no Tratamento de Doentes Alcoólicos}

As intervenções breves eficazes não consistem apenas em dizer as palavras certas ao paciente, mas sobretudo em criar um ambiente seguro e acolhedor, no entendimento de que cabe ao doente, e não ao profissional da saúde, a responsabilidade última pela modificação comportamental desejada e necessária, e que o papel do profissional é, antes de tudo, aumentar a motivação do doente e funcionar como uma 'ferramenta', um recurso, para a necessária mudança do comportamento.

Uma condição fundamental para o sucesso da intervenção breve é avaliar se o paciente está pronto para a mudança, visto que se essa avaliação não for feita, o resultado clínico pode ser insatisfatório.

No processo de mudança comportamental,é importante avaliar os estágios necessários à aquisição e à manutenção das modificações do comportamento, conforme evidenciado nos estudos de Prochaska e DiClemente (1983), bem como a intervenção terapêutica adequada em cada estágio, como ilustrado a seguir (Figura 3): 
Figura 3 - Estágios da mudança comportamental

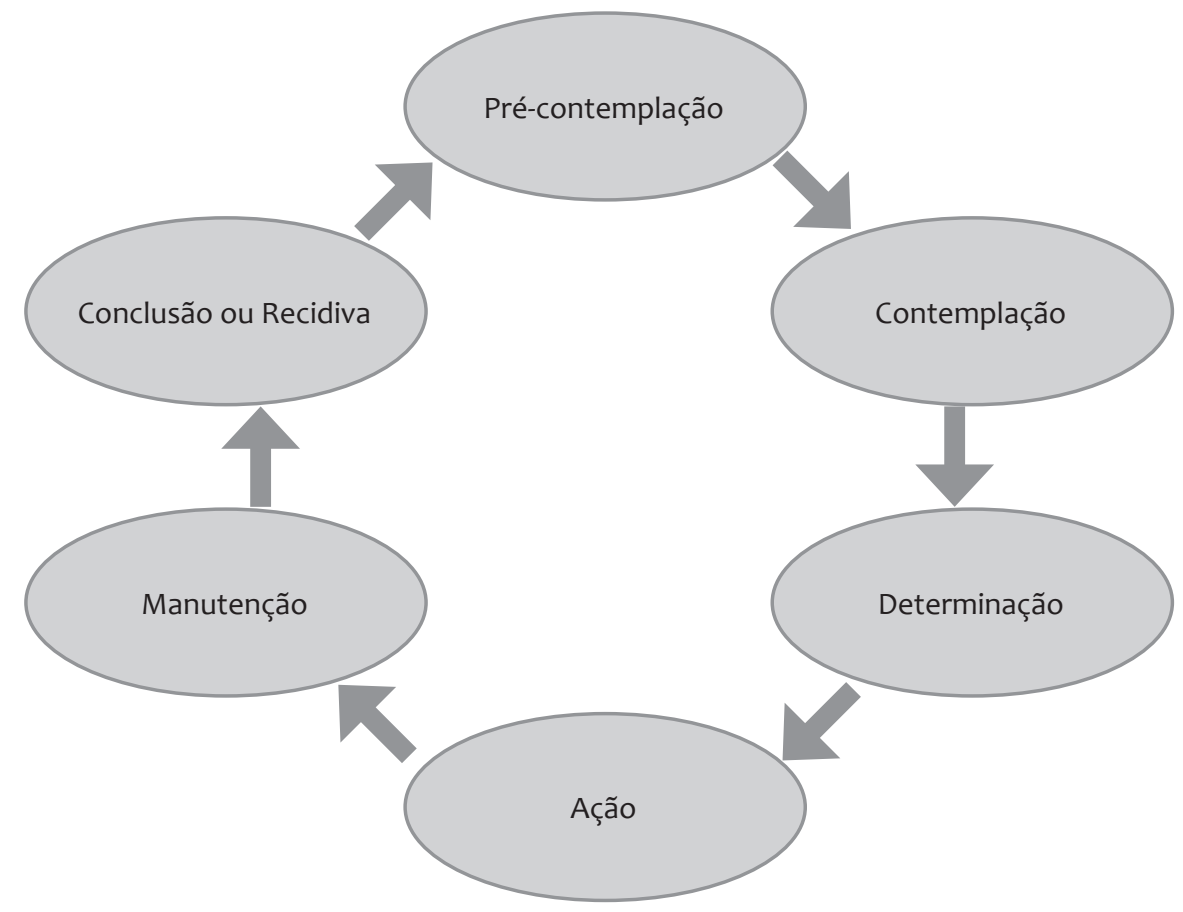

Fonte: adaptado de Prochaska e DiClemente, 1983.

$\mathrm{Na}$ fase de pré-contemplação, a sensação prazerosa é preponderante, e o paciente não sente necessidade da mudança.A intervenção terapêutica é difícil, a não ser que o indivíduo esteja motivado, intrínseca ou extrinsecamente, por algum fato que possa suscitar dúvidas a respeito da continuação do nível atual do consumo de álcool.

A contemplação é a fase em que o paciente começa a tomar consciência dos problemas causados pelo álcool, ou seja, dos prós e contras do seu consumo alcoólico. É, portanto, a fase da ambivalência. É o momento em que o profissional pode desenvolver e capitalizar essa ambivalência e ajudar o paciente a refletir sobre os prós e contras de não interromper o consumo, esclarecer os conflitos e evoluir para o planejamento de uma modificação comportamental.

O estágio de determinação é aquele no qual ocorre a decisão a respeito da modificação do comportamento, que inclui a preparação mental, assim como o planejamento concreto do tratamento efetivo. É quando o doente está a 
meio caminho no processo de modificação. O papel do profissional é discutir as opções terapêuticas disponíveis, ajudar o doente a revisar os recursos de apoio familiar e social para a mudança, bem como desenvolver um plano de ação e estabelecer metas para a abstinência.

Ao passar para a fase de ação, o doente compromete-se a desenvolver alterações comportamentais específicas, iniciando um estágio de aprendizado para não consumir álcool, portanto, colocando em prática a abstinência. A intervenção do profissional deve fundamentar-se em ajudar o paciente a executar a modificação comportamental pretendida.

A fase de manutenção é a fase de continuidade da ação, em que evitar a recidiva do comportamento pregresso é uma tarefa crucial, visto que os novos comportamentos podem causar embaraço e desconforto. É uma fase em que o papel do profissional é extremamente importante, sobretudo para dar o apoio e orientação necessários para manter o comportamento adotado.

Na última fase, de conclusão ou recidiva, é possível que a mudança comportamental esteja tão incorporada que a recidiva seja uma possibilidade remota. Entretanto, a recidiva é um estágio possível, visto que, em média, os doentes fazem de três a quatro tentativas de interrupção do consumo antes de conseguirem a abstinência permanente. Se a recidiva vier a ocorrer, o paciente pode voltar a qualquer um dos estágios precedentes e progredir novamente pelas fases da mudança comportamental.

Em todo o processo, o objetivo do profissional deve ser o de ajudar o paciente a passar ao estágio seguinte da modificação e estabelecer metas alcansáveis que, por fim, resultarão na interrupção do consumo excessivo de álcool e, consequentemente, na abstinência permanente. Assim, os profissionais podem lançar mão de dois instrumentos primordiais: a estimulação motivacional e a escuta reflexiva.

A estimulação motivacional tem por base os conceitos de autonomia, ambivalência e motivação intrínseca do paciente, e sua tarefa fundamental é ajudar o doente a lidar com a ambivalência provocada pela modificação comportamental necessária (Bien, Miller \& Tonigan, 1993; Miller \& Sovreign, 1989; O’Malley et al., 1995), cujos aspectos mais importantes a considerar são representados pelos objetivos, pela motivação e pelas opções do paciente, tendo-se em conta que a motivação intrínseca, desencadeada pelos próprios desejos, objetivos e necessidades pessoais, é mais importante para a realização de uma mudança do que a motivação extrínseca - pressões familiares, confrontação do profissional, pressão judicial etc. (Miller \& Sovreign, 1989). 
$\mathrm{Na}$ estimulação motivacional, o profissional deve ter como objetivo ajudar o paciente a articular internamente as modificações que conduzirão à abstinência e a adquirir a crença de que a mudança é importante, e que,com isso, ele terá uma chance maior de obter sucesso.

Já a escuta reflexiva tem por objetivos compreender o significado subjacente às afirmações verbais e aos comportamentos não verbais e repassar esse significado ao doente. É importante ressaltar que, por meio dela, o profissional pode aumentar a motivação do paciente para a mudança do comportamento (Miller \& Sovreign, 1989).

Considerando-se que os doentes são ambivalentes no que diz respeito à mudança comportamental, o seu grau de resistência é determinado pela postura do profissional: se empática, de pouca resistência e, contrariamente, de grande resistência diante de postura confrontadora.Assim, ao abordar um paciente com problemas associados ao álcool, a aplicação das técnicas de estimulação motivacional é, sem dúvida, mais eficaz que uma abordagem de confronto.

Desse modo, as intervenções breves incluem o fornecimento de feedback ao paciente a respeito do comportamento alcoólico, recomendação clara de uma modificação comportamental, apresentação de opções de como atingi-la, análise e resposta às reações do paciente e garantia de acompanhamento, podendo dessa forma, ajudar a desenvolver os sensos de motivação e autoeficácia do doente, necessários à modificação comportamental (Bien, Miller \& Tonigan, 1993; Miller \& Sovreign, 1989; NIAAA, 1995; O'Malley et al., 1995), cujo sucesso, segundo as postulações de Miller e Rollnick (1991), depende de aspectos fundamentais, como apresentado nos pressupostos do Dares (Quadro 1) e de elementos que compõe uma intervenção breve bem-sucedida, segundo o modelo Frames (Quadro 2). 
Quadro 1 - Dares - Pontos fundamentais da estimulação motivacional

D Desenvolver a DISCREPÂNCIA

A Evitar a ARGUMENTAÇÃo

R Contornar a RESISTÊNCIA

E Expressar a EMPATIA

S Reforçar a AUTOEFICÁCIA

Fonte: adaptado de Miller e Rollnick, 1991.

Quadro 2 - Frames - Componentes da intervenção breve bem-sucedida

F Proporcionar FEEDBACK sobre o comportamento alcoólico

R Reforçar a RESPONSABILIDADE do doente na mudança comportamental

A Orientar (ADVICE) quanto à mudança comportamental

M Discutir um MENU de opções para a modificação do comportamento

E Expressar EMPATIA pelo doente

S Reforçar a autoeficácia (SELF-EFFICACY) do doente

Fonte: adaptado de Miller e Rollnick, 1991. 
Um aspecto extremamente relevante a ser ressaltado no contexto da intervenção breve centrada no Frames e no Dares é a imposição de uma prática profissional pautada nos princípios de ordem ética e humanista, capazes de funcionar nos dois sentidos, compreendendo ambos os polos do binômio profissional da saúde-paciente.

Em nossa experiência, acumulada ao longo de quase duas décadas, desenvolvemos a intervenção breve, com intervenção motivacional e escuta reflexiva, fundamentada nos paradigmas do Dares e do Frames, no seguimento dos doentes alcoólicos com complicações gastroenterológicas.

Nesse contexto, a abordagem terapêutica consiste em consultas de grupo de periodicidade semanal, com uma hora de duração, por um período mínimo de seis meses, e, a partir daí, follow-up com consultas periódicas, inicialmente mensais e posteriormente de três em três meses. Os resultados têm apontado para uma taxa de abstinência em torno de 87,5\%,considerando um tempo mínimo de observação de cinco anos. Esses resultados, provenientes da avaliação de 685 doentes, traduzem, entre outros, uma redução dos episódios de descompensação clínica, diminuição do número de atendimentos em serviços de urgência e internações, uma melhor qualidade de vida dos doentes mensuradas pelo SF36 e, sem dúvida nenhuma, uma redução do custo médico-social da doença alcoólica (dados a serem publicados).

\section{Referências}

ANTON, R. F \& BECKER, H. C. Pharmacotherapy and pathophysiology of alcohol withdrawal. In: KRANZLER, H. R. (Ed.). The Pharmacology of Alcohol Abuse. New York: Springer, 1995.

BABOR, T. \& GRANT, M. (Eds.).Program on Substance Abuse: project on identification and management of alcohol-related problems. Report on phase II: a randomized clinical trial of brief interventions in primary care. Geneva: World Health Organization, 1992.

BESSON, J. Les nouveaux medicaments dans le traitement de l'alcoolisme. Unité d'abus de substances du Département universitaire de psychiatrie adulte de Lausanne.Schweizerische Medizinische Wochenschrift, 127(38): 1.574-1.578, 1997.

BIEN, T. H.; MILLER, W. R. \& TONIGAN, J. S. Brief interventions for alcohol problems: a review.Addiction, 88: 315-336, 1993. 
BOHN, M. J.; BABOR,T.F\& KRANZLER, H.The alcohol use disorders identification test (AUDIT): validation of a screening instrument for use in medical settings. Journal of Studies on Alcohol, 56: 423-432, 1995.

CHAN,A.W.K. et al. Use of the TWEAK test in screening for alcoholism/heavy drinking in three populations. Alcoholism, Clinical and Experimental Research, 17(6): 1.188$1.192,1993$.

CHU, N. Carbamazepine: prevention of alcohol withdrawal seizures. Neurology, 29: 1.397, 1979.

CLEARY, P. D. et al. Prevalence and recognition of alcohol abuse in a primary care population. American Journal of Medicine, 85: 466-471, 1988.

DEITZ, D. et al. Prevalence of screening for alcohol use by physicians during routine physical examination. Alcohol Health \& Research World, 18: 162-168, 1994.

EDWARDS, G.; ORFORD, J. \& EGERT, S. Alcoholism: a controlled trial of treatment and advice.Journal of Studies on Alcohol,38: 1.004-1.031, 1977.

EWING, J. A. Detecting alcoholism: the CAGE questionnaire. Jama, 252: 1.905-1.907, 1984.

FLEMING, M.J.\& BARRY K. L.A three-sample test of a masked alcohol screening questionnaire. Alcohol and Alcoholism, 26: 81-91, 1991.

FLETCHER, R. H.; FLETCHER, S. W. \& WAGNER E. H. (Eds.). Clinical Epidemiology: the essentials. 3. ed. Baltimore:Williams \& Wilkins, 1996.

KAIM, S. C.; KLETT, C. J. \& ROTHFELD, B. Treatment of the Acute Alcohol Withdrawal State: a comparison of four drugs. American Journal of Psychiatry, 125: 1.640, 1969.

KRISTENSON, H. D. \& TRELL, E. Indicators of alcohol consumption: comparisons between a questionnaire (Mm-MAST), interviews, and serum gamma glutamyl transferase (GGT) in a health survey of middle aged men. British Journal of Addiction, 77: 297-304, 1982.

LIEBER, C. S. Metabolism and metabolic effects of alcohol. Seminars in Hematology, 17: 85-99, 1980.

LIEBER, C. S. Medical disorders of alcoholism. New England Journal of Medicine, 16: 1.058-1.065, 1995.

LISKOW, B. et al.Validity of the CAGE questionnaire in screening for alcohol dependence in a walk-in (triage) clinic. Journal of Studies on Alcohol, 56:277-281, 1995.

LUNDWALL, L. \& BAEKELAND, F. Disulfiram treatment of alcoholism. Journal of Nervous and Mental Disease, 153:381, 1971.

MILLER,W.R.\& ROLLNICK, S.Motivational Interviewing. New York: Guilford Press, 1991. 
MILLER,W. R. \& SOVREIGN, R. The Check-up: a model for early intervention in addictive behaviors. In: LOBERG, T. et al. (Eds.). Addictive Behaviors: prevention and early intervention. Amsterdam: Swets \& Zeitlinger, 1989.

NATIONAL INSTITUTE ON ALCOHOL ABUSE AND ALCOHOLISM (NIAAA). Physicians' Guide to Helping Patients with Alcohol Problems. Washington: National Institutes of Health Publication, 1995. (NIH Publication n. 95-3769)

O'MALLEY S. S. et al. Naltrexone in the Treatment of Alcohol Dependence: a combined analysis of two trials. Psychiatric Annals, 25: 681, 1995.

PROCHASKA, J. O. \& DICLEMENTE, C. C. Stages and Processes of Self-change of Smoking: toward an integrative model of change. Journal of Consulting and Clinical Psychology, 51:390-395, 1983.

TURNER R. C. et al. Alcohol withdrawal syndromes: a review of pathophysiology, clinical presentation, and treatment. Journal of General Intern Medicine, 4: 432, 1989.

VAILLANT, G. E. The Natural History of Alcoholism. Cambridge: Harvard University Press, 1983.

WILSON, A. \& VULCANO, B. A. A double-blind, placebo-controlled trial of magnesium sulfate in the management of the acute ethanol withdrawal syndrome. Alcoholism Clinical and Experimental Research, 9:23, 1985. 


\section{Políticas Sociais Públicas e a Centralidade da Família: implicações para a assistência na área de álcool e outras drogas}

Rita de Cássia Cavalcante Lima

Pretende-se, aqui, contribuir para as reflexões e práticas dos profissionais que atuam na assistência aos usuários de álcool e outras drogas, oferecendo-lhes uma reflexão para melhor avaliarem seus projetos sócio-ocupacionais relativos à atenção às famílias em virtude de algumas recentes políticas sociais públicas. Trata-se de um texto introdutório, que intenciona analisar implicações suscitadas pela emergência das políticas públicas da saúde mental e da assistência social para a área de álcool e outras drogas num cenário nacional desfavorável, tendo em vista o recrudescimento da violência urbana, o contingenciamento do orçamento público para investimento em certas políticas sociais públicas e os efeitos do desemprego estrutural e da pobreza relativa sobre os núcleos familiares.

Não se parte do pressuposto de que o Estado somente passou a intervir nos problemas advindos do uso de álcool e outras drogas a partir dos idos de 2000, com a Política Nacional de Assistência Social e com a Política do Ministério da Saúde para a Atenção Integral a Usuários de Álcool e outras Drogas, ambas anunciadas em 2004. Trata-se muito mais de um corte arbitrário, considerando, em particular, o contexto do Rio de Janeiro, na década de 1990, quando se deu a implantação de um conjunto de serviços de assistência a esse público, vinculados, inicialmente, à Justiça e à área da infância e juventude. No âmbito da saúde mental, apenas posteriormente, teve início o processo de acreditação 
dos Centros de Atenção Psicossocial (Caps ad) voltados para o atendimento aos usuários de álcool e drogas, e, em 2005, foram aprovadas as normas de funcionamento e credenciamento dos Serviços Hospitalares de Referência para a Atenção Integral aos Usuários de Álcool e outras Drogas (SHR ad).

A bibliografia disponível na área de família com foco na experiência relacional do uso prejudicial de álcool e outras drogas reflete, de alguma forma, uma preocupação do Estado com aquele que usa essas substâncias. No entanto, o desenvolvimento do conhecimento nessa área é motivado pela preocupação de outras instituições, como o campo psicossocial da assistência às famílias dos usuários. Este se configurou mais em função do desenvolvimento das disciplinas especializadas $^{1}$ - abordagens psicanalíticas e das terapias sistêmicas de família - do que por uma requisição do poder público, como política pública, para assistir de forma sistemática as famílias dos usuários de álcool e outras drogas.

Não se trata, no entanto, de se negar, aqui, o histórico reconhecimento da relevância das famílias, em geral, para os processos de socialização primária dos indivíduos e sua implicação para a organização societária mais ampla. Autores como os freudo-marxistas Wilhelm Reich (1897-1957) e Erich Fromm (1900-1980) trataram dessa relação ao longo das três primeiras décadas do século XX, quando tentaram entender como era possível produzir indivíduos adaptados à exploração e à dominação da ordem burguesa em pleno período de fortalecimento do nazifascismo na Europa. Por que os indivíduos não se rebelavam frente a um quadro tão desfavorável política e economicamente? Por que não conformavam de forma coletiva resistências e lutas diante de um cenário de importante crise econômica, que afetava diretamente às famílias? Segundo Rouanet (1998), para uma análise freudo-marxista, a família tornou-se central para o entendimento desse fenômeno: foi considerada como uma instância relevante, a agência psíquica mais importante na ação de modelar as consciências e de produzir os traços de caráter individual mais próximos do caráter social desejado pelos interesses das classes dominantes do período.

Assim, a teoria do caráter social se completa com uma teoria da política cultural. Se a socialização consiste em produzir estruturas caractereológicas individuais tendencialmente idênticas ao caráter social, esse resultado

\footnotetext{
1 Como sugestão de um texto sobre família, no qual se resenha brevemente essas influências na área de álcool e outras drogas, sugiro ver "A importância do envolvimento de familiares no tratamento de dependentes de drogas: uma experiência no Proad", de Suely Aparecida Fender (apud Silveira Filho \& Gorgulho, 1996).
} 
é alcançado, em primeira instância, através da família, como agência psíquica da sociedade, e mais tarde pelos diversos aparelhos culturais, que funcionam como instrumentos complementares da família, como mandatária do social. A família gera o caráter, que por um lado é ideologia ossificada, e por outro constitui o solo para a recepção das ideologias difundidas pelos demais aparelhos, cuja ação de conjunto consolida o caráter social, ao mesmo tempo em que nele se enraíza. (Rouanet, 1998: 65)

Feita essa breve observação, deve-se considerar o problema dos freudomarxistas ao tentarem integrar dois sistemas teóricos distintos, a psicanálise e o marxismo, de forma linear e até antidialética, 'sociologizando' o freudismo e 'psicologizando' o marxismo. Porém, pode-se creditar aos freudo-marxistas a reflexão de que se a família, por um lado, pode ser tomada como uma instância privilegiada na formação de cada indivíduo, ela, por outro lado, também abarca responsabilidades coletivas para a produção e reprodução dos principais parâmetros ético-políticos, ideológico-culturais e econômicos com base nas sociedades contemporâneas.

Portanto, no presente texto, o leitor encontrará dois principais pontos para orientar a construção das possíveis implicações na assistência às famílias de usuários de álcool e outras drogas: o primeiro alude à enunciação dos princípios das recentes políticas sociais públicas da saúde mental para a área de álcool e outras drogas e da assistência social, que redefinem as expectativas à assistência à família; o outro se refere a alguns desafios postos a essa assistência, considerando os novos matizes requeridos por essas políticas.

\section{A Política do Ministério da Saúde para a Atenção Integral a Usuários de Álcool e Outras Drogas}

Ao longo da década de 1990, o Ministério da Saúde produziu manuais técnicos visando a (re)orientar a assistência ao usuário de álcool e outras drogas na rede pública de saúde, sob a égide da área da saúde mental. O foco estava na qualificação dos trabalhadores da rede para o manejo daqueles indivíduos que faziam uso prejudicial do álcool e outras drogas. O tema da família não era tratado com profundidade, mas podia-se identificar a expectativa de que a família fosse envolvida pelo profissional no tratamento do usuário e atuasse como 
suporte em sua reabilitação. Havia, portanto, fronteiras razoavelmente definidas entre o usuário de álcool e outras drogas e sua família: aquele consumia de forma prejudicial as substâncias psicotrópicas e requeria tratamento, e estes, por serem família, deveriam coparticipar da assistência proposta pela equipe de saúde com vistas à remissão dos sintomas associados ao uso do álcool e outras drogas. A percepção da família parecia passar pelo seu aparente lugar de não consumidora prejudicial dessas substâncias e pela sua possibilidade de ser coadjuvante na assistência e retaguarda no cuidado ao usuário.

Após diagnosticar o paciente (e sua família), o procedimento seguinte é engajá-lo(s) em um tratamento. (...) O reconhecimento do alcoolismo como uma doença - e não defeito moral - poderá aliviar, no paciente, sentimentos de culpa, desânimo e desesperança, levando-o a aceitar melhor o tratamento. O familiar, também, na medida em que percebe o paciente como uma pessoa doente e não um 'sem-vergonha', atenuará sentimentos hostis de condenação e de desânimo, facilitando assim a tarefa de auxiliá-lo. (Brasil/MS, 1990: 18)

E ainda:

Ao deparar com um alcoolista intoxicado, a primeira questão a ser ponderada pelo profissional de saúde é verificar se esta situação pode ser tratada ambulatorialmente ou se está indicada a hospitalização do paciente.

A decisão deverá nortear-se pelos seguintes critérios:

a) intensidade dos sintomas de abstinência;

b) nível das complicações orgânicas e psíquicas;

c) nível da aceitação do paciente à sua própria realidade;

d) nível da retaguarda familiar e assistência disponível. (Brasil/MS, 1990: 19)

No entanto, não se poderia exigir da política pública da saúde mental, no período, uma discussão ampla sobre as famílias diante da experiência do uso prejudicial de álcool e outras drogas, muito menos do próprio uso dessas substâncias. Deve-se lembrar que a saúde mental encontrava-se, à época, no Brasil, envolvida com a implantação dos serviços substitutivos ao manicômio e com a articulação de lutas no campo jurídico² e cultural para afirmar direitos civis,

2 A lei federal n. 10.216/2001 (Brasil, 2001) constitui um marco legal da reforma psiquiátrica: dispõe sobre a proteção e os direitos das pessoas portadoras de transtornos mentais e redireciona o modelo assistencial em saúde mental. 
políticos e sociais aos usuários com transtorno mental e, de forma simultânea, consolidar um novo modelo assistencial sob base comunitária.

É importante lembrar, ainda, que, na década de 1990, o alcoolismo representava a segunda causa de internação psiquiátrica no país. A estratégia assistencial adotada pela reforma psiquiátrica demonstrou que o foco prioritário era desinstitucionalizar os psicóticos internados de longa duração nos hospitais psiquiátricos. Os Caps assumiram, gradativamente, a prerrogativa de oferecer assistência extra-hospitalar, de base territorial, intentando substituir o modelo hospitalocêntrico. Os alcoolistas e os usuários de outras drogas com quadro de dependência psíquica e/ou física não foram, naquele momento, alvo da atenção da saúde mental. ${ }^{3}$

Porém, não se pode restringir uma política pública da saúde a apenas um dos seus setores. Outras iniciativas do Ministério da Saúde organizaram-se, nessa década, em diversas áreas de ação, como a política pública de combate ao tabagismo, implementada pelo Instituto Nacional do Câncer (Inca), a redução de danos para os usuários de drogas injetáveis e, finalmente, a definição de regras para o funcionamento das comunidades terapêuticas. ${ }^{4}$

A atual política pública da saúde, intitulada Política do Ministério da Saúde para a Atenção Integral a Usuários de Álcool e Outras Drogas, apresentou seus

\footnotetext{
3 Um dos principais periódicos da saúde mental, no Brasil, são os Cadernos Ipub. Analisandose uma amostra de 17 números do periódico, entre os anos de 1995 a 2000, observa-se que o tema do uso de álcool e drogas não constituiu uma preocupação desse campo. No conjunto dos 220 artigos dessa amostra, o alcoolista emerge em algumas cenas dos serviços relatadas, mas não se torna questão para reflexão. Somente no número 16 do ano de 1999 foi possível encontrar um artigo intitulado Álcool, Drogas e Família - um eterno desafio, de Lia Ganc. O número 6 do ano de 1997 do periódico em questão, com o título Saúde Mental no Hospital Geral, chamou a atenção porque abordou outros quadros clínicos referentes à cardiopatia, oncologia, Aids e lúpus, silenciando sobre a clássica passagem do alcoolista intoxicado por esse tipo de unidade de saúde.

4 Refiro-me à política do Inca de estabelecer princípios e condutas para o tratamento do tabagista na rede pública de saúde e às estratégias de impacto na opinião pública que resultaram na diminuição sensível do consumo dessa droga no Brasil. Outra preocupação do Ministério da Saúde se deu com os usuários de drogas injetáveis, os quais apresentam comportamentos que os colocam sob risco de contágio e transmissão do HIV, hepatites B e C e sífilis. Com relação a esses tópicos, foram implementados programas de redução de danos que prestam assistência em saúde no próprio local onde se congregam os usuários de drogas, cuja assistência, em parte, se traduz em ações socioeducativas e na troca da seringa utilizada por outra estéril. Esse programa enfrentou várias resistências, inclusive por parte da força policial e do Judiciário, dada a legislação em vigor, mas vem obtendo resultados satisfatórios ao reduzir o risco de agravos à saúde do usuário. Uma terceira ação desenvolvida pelo Ministério da Saúde foi a implantação de grupos de trabalho para diversos temas. O grupo coordenado pela Secretaria de Vigilância em Saúde estabeleceu parâmetros para o funcionamento das internações dos usuários de álcool e de outras drogas sob a modalidade de comunidade terapêutica.
} 
principais marcos institucionais já no ano de 2002. Um de seus dispositivos normativos foi a portaria n. GM/816/2002 (Brasil, 2002), que instituiu, no Sistema Único de Saúde (SUS), o Programa Nacional de Atenção Comunitária Integrada aos Usuários de Álcool e de outras Drogas. Por meio desse programa, foi prevista a implantação de 250 Caps ad, no país, prevendo como estratégia assistencial a redução de danos e a reversão de um quadro assistencial sustentado fundamentalmente por iniciativas da sociedade civil, sejam os grupos de Alcoólicos Anônimos (AA), sejam as comunidades terapêuticas religiosas. No texto oficial do Ministério da Saúde referente a essa política, parece haver uma adjetivação que desqualifica os tratamentos desenvolvidos até então, deslocando de forma pouco cuidadosa a crítica atribuída aos manicômios psiquiátricos para todos os outros serviços da área de álcool e outras drogas.

No vácuo de propostas concretas, e na ausência do estabelecimento de uma clara política de saúde voltada para este segmento, surgiram no Brasil diversas 'alternativas de atenção' de caráter total, fechado e tendo como único objetivo a ser alcançado a abstinência. (Brasil/MS, 2004: 5)

Nesse caso, como analisar, por exemplo, a experiência dos grupos familiares como o Al-Anon e o Nar-Anon, que, a despeito de estimularem seus membros a apoiar a reabilitação do usuário no horizonte da abstinência, oferecem, em espaço comunitário, laico e aberto, uma rede territorializada fecunda em termos de acolhimento, suporte, autoconhecimento e apoio mútuo? Caminho que propicia, também, em alguns núcleos familiares, a convivência com o usuário sob os efeitos do recorrente uso prejudicial do álcool e outras drogas. Podem essas experiências internacionais e locais ser tomadas como "de caráter total", "fechado", e "tendo como único objetivo a ser alcançado a abstinência" (Brasil/MS, 2004)?

No entanto, no mesmo documento, o Ministério da Saúde se coloca de forma mais cautelosa e específica dirigindo sua crítica aos manejos assistenciais preexistentes:

Sem que deixemos de considerar a existência destes métodos, com os quais temos ainda muito de debater, queremos indicar que, em se tratando de tema tão complexo, com claras implicações sociais, psicológicas, econômicas e políticas, traçar uma política com base em um único objetivo é trabalhar em saúde com um modo estreito de entendimento. (Brasil/MS, 2004: 10) 
A afirmação, portanto, do ministro da Saúde de que "o atraso histórico de assunção desta responsabilidade pelo SUS" (Brasil/MS, 2004: 6) exige dos principais atores dessa política uma importante habilidade de negociação, na medida em que tal política não encontrou um vácuo de ações, mas sim um arranjo assistencial de múltiplos sujeitos e interesses expressos pela criminalização do usuário; defesa do isolamento como prerrogativa para o tratamento em parte das comunidades terapêuticas religiosas; baixo potencial da organização política dos usuários dessas políticas e dos trabalhadores da área, além de uma lógica belicista de 'combate às drogas'.

Ainda no mesmo documento, o binômio usuário de álcool e outras drogas/ família parece ter suas fronteiras reconfiguradas face à estratégia da redução de danos e sua proposta de estabelecer a "rede de saúde como local de conexão e de inserção" (Brasil/MS, 2004: 10):

a abordagem se afirma como clínico-política, pois, para que não reste apenas como 'mudança comportamental', a redução de danos deve se dar como ação no território, intervindo na construção de redes de suporte social, com clara pretensão de criar outros movimentos possíveis na cidade, visando a avançar em graus de autonomia dos usuários e seus familiares, de modo a lidar com a hetero e a autoviolência muitas vezes decorrentes do uso abusivo do álcool e outras drogas, usando recursos que não sejam repressivos, mas comprometidos com a defesa da vida. (...) Nunca é demais, portanto, insistir que é a rede - de profissionais, de familiares, de organizações governamentais e não governamentais em interação constante, cada um com seu núcleo específico de ação, mas apoiando-se mutuamente, alimentando-se enquanto rede - que cria acessos variados, acolhe, encaminha, previne, trata, reconstrói existências, cria efetivas alternativas de combate ao que, no uso das drogas, destrói a vida. (Brasil/MS, 2004: 11)

A preocupação com a família deixa de ser o possível suporte aos procedimentos de remissão da sintomatologia clínica do alcoolista - como na desintoxicação. Desse modo, a família passa a atuar como um sujeito ativo na 'rede', sendo orientada pelas múltiplas demandas do exercício dos direitos: tanto pode propiciar atenção na 'rede' como também pode ser assistida no território. Trata-se de uma proposta apoiada na redução de danos, que visa a transmutar o usuário e seu contexto familiar e comunitário de uma condição exclusiva de aprisionamento pela experiência do uso prejudicial do álcool e outras drogas para a condição de sujeitos 'ampliados' pela 'clínica-política'. 
Queremos resgatar aqui o duplo sentido da clínica: o de 'inclinar-se' (klinikós), acolhendo o paciente e sua história, e o de produzir um desvio (clinamem) para produzir outra história, outra possibilidade de existência. (Benevides apud Brasil/MS, 2004: 10)

\section{A Política Nacional de Assistência Social e o Sistema Único da Assistência Social}

A área da assistência social no Brasil, até a Constituição de 1988, poderia ser associada, no senso comum, às práticas assistenciais voluntaristas implementadas por organizações da sociedade civil, filantrópicas e religiosas. Poderse-ia confundir, então, a assistência social com a 'caridade', havendo baixa visibilidade das responsabilidades do poder público na prestação dessas políticas públicas.

O título VIII da Constituição Federal - Da Ordem Social - passou a inscrever a assistência social no bojo dos direitos da seguridade social ao lado das políticas sociais públicas da saúde e da previdência social. Essa ascensão da assistência social ao campo da regulação do Estado e das garantias oferecidas ao cidadão, como política pública, deve ser entendida no âmago das requisições e das lutas dos movimentos sociais e das corporações profissionais organizados no período.

Art. 194. A seguridade social compreende um conjunto integrado de ações de iniciativa dos poderes públicos e da sociedade, destinadas a assegurar os direitos relativos à saúde, à previdência e à assistência social. (...)

Art. 203. A assistência social será prestada a quem dela necessitar, independentemente de contribuição à seguridade social, e tem por objetivos:

I. A proteção à família, à maternidade, à infância, à adolescência e à velhice;

II. O amparo às crianças e adolescentes carentes;

III. A promoção da integração ao mercado de trabalho;

IV. A habilitação e reabilitação das pessoas portadoras de deficiência e a promoção de sua integração à vida comunitária;

V. A garantia de um salário mínimo de benefício mensal à pessoa portadora de deficiência e ao idoso que comprovem não possuir meios 
de prover a própria manutenção ou de tê-la provida por sua família, conforme dispuser a lei. (Cress, 2000: 41)

Após a promulgação da Constituição de 1988, um conjunto de leis é criado, regulamentando os dispositivos pactuados. Algumas dessas leis merecem ser lembradas, pois exprimem certas tendências que caracterizarão as políticas emanadas do Estado na área social, ao longo da década de 1990, com forte impacto sobre a organização dos serviços públicos, sobre os projetos sócioocupacionais das categorias profissionais e, fundamentalmente, sobre aspectos legais que os trabalhadores deverão conhecer a fim de lidar com situações cotidianas. São elas: a lei n. 7.853, de 24 de outubro de 1989 (Lei da Pessoa Portadora de Deficiência); lei n. 8.069, de 13 de julho de 1990 (Estatuto da Criança e do Adolescente - ECA); lei n. 8.080, de 19 de setembro de 1990 (Lei Orgânica da Saúde - LOS); lei n. 8.142, de 28 de dezembro de 1990 (complementa a LOS); lei n. 8.742, de 7 de dezembro de 1993 (Lei Orgânica da Assistência Social - Loas); lei n. 8.842, de 4 de janeiro de 1994 (Política Nacional do Idoso e cria o Conselho Nacional do Idoso); e a lei n. 9.394, de 20 de dezembro de 1996 (Lei de Diretrizes e Bases da Educação - LDB).

A Loas merece destaque por representar o substrato legal sobre o qual se assentou, 11 anos depois, em 2004, a proposta para a Política Nacional da Assistência Social, quando esta foi elaborada e tornada pública pelo Ministério do Desenvolvimento Social e Combate à Fome e pelo Conselho Nacional de Assistência Social. Dois elementos dessa política serão aqui sublinhados para dar densidade à discussão sobre a assistência às famílias: primeiro, de forma similar ao campo da saúde, que implementou o SUS, a assistência social estabelece um 'choque de gestão', com a implantação do Sistema Único da Assistência Social (Suas); segundo, um dos eixos fundamentais do Suas será a assim denominada 'matricialidade sociofamiliar'.

O Suas, cujo modelo de gestão é descentralizado e participativo, constituise na regulação e organização em todo o território nacional da rede de serviços socioassistenciais. Os serviços, programas, projetos e benefícios têm como foco prioritário a atenção às famílias, seus membros e indivíduos e o território como base de organização, que passam a ser definidos pelas funções que desempenham, pelo número de pessoas que deles necessitam e pela sua complexidade (...). O Suas materializa o conteúdo da Loas, cumprindo no tempo histórico dessa política as exigências para a realização 
dos objetivos e resultados esperados que devem consagrar direitos de cidadania e inclusão social (Brasil/MDS, 2004: 23).

Mas, efetivamente, quais os impactos que podem ser observados no cotidiano dos profissionais a partir da implementação dessa política pública? Em especial, com relação a todos aqueles que já estão inseridos nos serviços, programas e projetos da assistência social?

Os objetivos da Política Nacional da Assistência Social definem-se com base na distinção entre a proteção social básica e a proteção social especial para famílias, indivíduos e grupos. Trata-se de termos e lógicas recentes no campo da assistência social, os quais preveem a organização da assistência às famílias de forma hierarquizada, de modo a assegurar o "provimento de condições para atender contingências sociais e promovendo a universalização dos direitos sociais" (Brasil, 1993). Tanto a universalização dos direitos quanto a reversão das assim denominadas contingências sociais dependem do primado do acesso ao trabalho na ordem vigente, exigindo da assistência social e das demais políticas sociais públicas uma intersetorialidade mais ampla, que reivindique, no mínimo, sua concomitância ao crescimento econômico e também a diminuição das desigualdades sociais.

Essa assertiva tem lugar na atualidade quando se observam os riscos em curso ao se atribuir um caráter assistencial à política pública da assistência social no país, na medida em que seu principal programa refere-se à transferência direta de renda às famílias - o Bolsa Família - com uma vinculação insuficiente de seus beneficiários a programas de (re)qualificação para o trabalho e inserção no mercado.

Nesse contexto, o que estaria sendo chamado de 'proteção social básica' e de 'proteção social especial na assistência social'?

O Bolsa Família, por exemplo, é considerado um programa inscrito na proteção social básica, pois “destina-se à população que vive em situação de vulnerabilidade social decorrente da pobreza, privação (ausência de renda, precário ou nulo acesso aos serviços públicos, dentre outros) e, ou, fragilização de vínculos afetivos" (Brasil/MDS, 2004: 19). Essa fragilização pode se dar, segundo essa política, por fatores relacionais e de pertencimento social do tipo "discriminações etárias, étnicas, de gênero ou por deficiências, dentre outras" (Brasil/ MDS, 2004: 19).

A dependência às drogas aparece duas vezes no texto da Política Nacional de Assistência Social. A primeira vez em que é citada pode ser observada quando se define o público-alvo da política da assistência social no país: 
Constitui o público usuário da política de Assistência Social, cidadãos e grupos que se encontram em situações de vulnerabilidade e riscos, tais como: famílias e indivíduos com perda ou fragilidade de vínculos de afetividade, pertencimento e sociabilidade; ciclos de vida; identidades estigmatizadas em termos étnico, cultural e sexual; desvantagem pessoal resultante de deficiências; exclusão pela pobreza e, ou, no acesso às demais políticas públicas; uso de substâncias psicoativas; diferentes formas de violência advindas do núcleo familiar, grupos e indivíduos; inserção precária ou não inserção no mercado de trabalho formal e informal; estratégias e alternativas diferenciadas de sobrevivência que podem representar risco pessoal e social. (Brasil/MDS, 2004: 19 - grifos meus)

O segundo momento em que aparece no texto uma alusão ao uso de álcool e outras drogas é justamente quando se define a proteção social especial como aquela que é prevista para apoiar estratégias de atenção sociofamiliar em face de problemas específicos e/ou abrangentes.

A proteção social especial é modalidade de atendimento assistencial destinada a famílias e indivíduos que se encontram em situação de risco pessoal e social, por ocorrência de abandono, maus tratos físicos e, ou, psíquicos, abuso sexual, uso de substâncias psicoativas, cumprimento de medidas socioeducativas, situação de rua, situação de trabalho infantil, dentre outras. (Brasil/MDS, 2004: 22 - grifos meus)

Nesse contexto em que se busca organizar a assistência social no país, com base em um sistema complexo e hierarquizado de serviços, programas e projetos, emergem duas modalidades assistenciais principais quanto à configuração da proteção social básica e da proteção social especial, respectivamente, o Centro de Referência da Assistência Social (Cras) e o Centro de Referência Especializado da Assistência Social (Creas). Se a saúde mental indicou o Caps ad como serviço estratégico e organizador da assistência aos usuários de álcool e outras, os Cras e os Creas parecem poder assumir corresponsabilidades no âmbito da assistência social para esse público. Em especial, a implantação dos Creas no país poderá fazer com que gestores e conselheiros da assistência social os convoquem para assumir parte da responsabilidade da prevenção e proteção às famílias que sofrem com o uso e o tráfico de drogas.

No caso do Rio de Janeiro, a V Conferência Estadual de Assistência Social, realizada em 2005, foi precedida pela elaboração de documentos organizados 
pela antiga gestão estadual dessa política social denominados Álbum de Fotografias Estadual e Sintese da Consolidação das Deliberações das Conferências Municipais de Assistência Social (Rio de Janeiro, 2005), nos quais se podem observar dois dados de relativa importância sobre a tomada de responsabilidade da assistência social em relação ao 'problema drogas'.

Primeiro, dentre os programas e projetos estaduais da assistência social no estado do Rio de Janeiro, já constava a linha de ação Atenção à Dependência Química, à qual correspondia, em 2004, recurso anual da ordem de R\$ 7.355.712,00 (sete milhões trezentos e cinquenta e cinco mil setecentos e doze reais), que ocupava a sétima posição em ordem decrescente no conjunto das ações implementadas. As demais ações eram: primeira, Transferência de Renda; segunda, Acesso à Alimentação; terceira, Atenção à Criança e Adolescente; quarta, Atenção à Família; quinta, Atenção à Pessoa Portadora de Deficiência; e sexta, Atenção à População de Rua.

Como programas mais emblemáticos dessas linhas de ação, em 2004, com relação à atenção ao usuário de drogas, sob a gestão da assistência social, tinham-se: convênios com entidades de atenção a crianças e adolescentes, desenvolvidos pela Fundação para Infância e Adolescência (FIA) e o Programa Clínicas Populares (Atenção à Dependência Química).

Como se pode depreender das informações mencionadas, um certo tipo de atenção ao usuário de drogas já se encontrava em curso pelo governo do estado do Rio de Janeiro, no ano de 2004, na área da assistência social, cuja realidade coincidiu com o resultado do Álbum de Fotografias Estadual (Rio de Janeiro, 2005). Nesse documento, os gestores municipais da assistência social se pronunciaram sobre as " 10 situações de vulnerabilidade e risco social que mais se destacam no estado". A preocupação desses gestores com o uso prejudicial de álcool e outras drogas sofre a seguinte atenção em face de outros problemas que afetam as famílias (Quadro 1):

Quadro 1 - Dez situações de vulnerabilidade e risco social na área urbana geral do Estado

\begin{tabular}{|l|l|}
\hline Colocação & Risco e Vulnerabilidade \\
\hline $1^{0}$ & Desemprego, subemprego, trabalho informal e precarizado \\
\hline $2^{\circ}$ & Moradias/domicílios precários e inadequados \\
\hline $3^{0}$ & Uso abusivo de drogas lícitas e ilícitas/dependência química \\
\hline $4^{\circ}$ & Famílias em situação de pobreza, indigência, miséria e baixa renda \\
\hline
\end{tabular}


Quadro 1 - Dez situações de vulnerabilidade e risco social na área urbana geral do Estado (cont.)

\begin{tabular}{|l|l|}
\hline Colocação & Risco e Vulnerabilidade \\
\hline $5^{\circ}$ & Gravidez e maternidade na adolescência \\
\hline $6^{\circ}$ & Baixa qualificação profissional e dificuldade de acesso à profissionalização \\
\hline $7^{\circ}$ & Territórios com saneamento básico e infraestrutura precários e insuficientes \\
\hline $8^{\circ}$ & Baixa escolaridade \\
\hline $9^{\circ}$ & Violência doméstica \\
\hline $10^{\circ}$ & $\begin{array}{l}\text { Domicílios chefiados por mulheres sem cônjuges, com filhos menores de } 15 \\
\text { anos, em situação de pobreza }\end{array}$ \\
\hline
\end{tabular}

No que se refere à área rural, os gestores da assistência social mantiveram o uso abusivo de drogas lícitas e ilícitas e dependência química em terceira posição, juntos, só perdendo para a questão da moradia, em segunda colocação, e para o desemprego, em primeira.

A exposição desses dados sobre as configurações que a assistência social estava ganhando no país e em particular no Rio de Janeiro justifica que, na atualidade, refletir sobre a política pública de assistência ao uso nocivo de álcool e outras drogas requer levar em consideração a coparticipação da assistência social nessa área, sendo este, portanto, o segundo ponto referido sobre a tomada de responsabilidade dessa política social pública quanto ao problema drogas. Talvez essa tendência possa ser melhor observada no âmbito da proteção social especial aos indivíduos, grupos e famílias sob violação de direitos, por intermédio dos Creas, dos quais se demandarão respostas relativas à assistência ao uso prejudicial do álcool e outras drogas:

São serviços que requerem acompanhamento individual e maior flexibilidade nas soluções protetivas. Da mesma forma, comportam encaminhamentos monitorados, apoios e processos que assegurem qualidade na atenção protetiva e efetividade na reinserção almejada. (Brasil/MDS, 2004: 19)

\section{Matricialidade sociofamiliar na assistência social}

O caráter mais descritivo dos itens anteriores abre caminho para uma problematização das concepções de famílias que circundam a atmosfera ideológica dos trabalhadores na área de álcool e outras drogas. 
No caso da política pública de saúde, no final da década de 1990, o Ministério da Saúde assume uma posição de reorientação do modelo assistencial por meio do Programa Saúde da Família (PSF), visando a fortalecer a atenção básica e a romper com o comportamento passivo das unidades básicas de saúde:

O Programa de Saúde da Família (PSF) foi criado pelo Ministério da Saúde em 1994. No entanto, é a partir de 1998 que o programa se consolida como estratégia estruturante de um modelo de atenção à saúde que priorize ações pautadas nos princípios da territorialização, da intersetorialidade, da descentralização, da corresponsabilização e da equidade, priorizando grupos populacionais com maior risco de adoecer ou morrer, ou seja em consonância com os princípios do Sistema Único de Saúde - SUS. (Brasil/ MS, 2006: 10)

Nesse contexto, a saúde mental, bem como outros setores da saúde, tem articulado ações, treinamentos e políticas, a fim de fortalecer a assistência em saúde mental no âmbito da atenção básica.

No bojo dessas iniciativas, a nascente política pública de assistência social também delimita em seu escopo o que denomina matricialidade sociofamiliar, por alusão à relevância do grupo familiar como locus privilegiado para o direcionamento das políticas sociais públicas:

As reconfigurações dos espaços públicos, em termos dos direitos sociais assegurados pelo Estado democrático de um lado, e, por outro, dos constrangimentos provenientes da crise econômica e do mundo do trabalho, determinaram transformações fundamentais na esfera privada, ressignificando as formas de composição e o papel das famílias. Por reconhecer as fortes pressões que os processos de exclusão sociocultural geram sobre as famílias brasileiras, acentuando suas fragilidades e contradições, fazse primordial sua centralidade no âmbito das ações da política de assistência social, como espaço privilegiado e insubstituível de proteção e socialização primárias, provedora de cuidados aos seus membros, mas que precisa também ser cuidada e protegida. Essa correta percepção é condizente com a tradução da família na condição de sujeito de direitos, conforme estabelece a Constituição Federal de 1988, o Estatuto da Criança e do Adolescente, a Lei Orgânica de Assistência Social e o Estatuto do Idoso. (Brasil/MDS, 2004:25) 
Assim, tanto a saúde como a assistência social referem priorizar e estabelecer suas intervenções, monitoramento e avaliação, tomando como base a recorrente referência às famílias. Nesse caso, utiliza-se o termo família no plural, uma vez que a intenção é apreender as particularidades históricas, regionais, culturais, econômicas e políticas que atravessam a configuração das famílias a cada conjuntura. Precisamente, há uma postura no campo dessas políticas sociais de tomar as famílias não como uma imagem preconcebida, única e modelar, mas de apreendê-las em sua multiplicidade, cotidianidade e subjetividade, ancoradas em um terreno material e simbólico da vida concreta.

Mas, efetivamente, a quais concepções de famílias estamos nos referindo?

Uma das mais desenvolvidas e criticadas concepções recai sobre o modelo da família nuclear, ${ }^{5}$ o qual só pode ser pensado a partir da conformação do modo de produção capitalista, por volta do século XVIII. A ascensão e a progressiva conquista da hegemonia da burguesia em meio à crescente urbanização sofrida na Europa implicaram uma importante ruptura com a forma de organização da sociedade precedente, erigindo o que se convencionou referir como modelo da família nuclear burguesa. Segundo Bruschini, citada por Morgado, "a família nuclear burguesa, com seu modelo de assimetria sexual, não é um modelo único ou norma universal, mas sim um fenômeno historicamente construído" (apud Morgado, 2001: 192-193). Nesse caso, Bruschini está chamando atenção para o grave risco de se tomar a formação das famílias como fenômeno natural, biológico e a-histórico:

com as transformações ocorridas com o advento da industrialização, houve uma ruptura que provocou o surgimento de duas esferas distintas: de um lado a unidade doméstica, de outro a unidade de produção. A essa fragmentação correspondeu uma divisão sexual do trabalho mais rígida do que a que predominava anteriormente. À mulher coube principalmente a realização de tarefas relativas à reprodução da força de trabalho na esfera privada do lar e sem remuneração, enquanto ao homem coube o trabalho produtivo extralar, pelo qual passou a receber remuneração. (Bruschini apud Morgado, 2001: 193)

\footnotetext{
5 O modelo de família nuclear refere-se à ideia de que a família é constituída por um casal e filho(s), requerendo, para a sua configuração, a existência de laços consanguíneos de unidade e domicílio comum. Sobre ela incide uma visão de papéis integrados, harmônicos e a-históricos entre seus membros: "O modelo de família nuclear burguesa tem, assim, como uma de suas principais características, a naturalização da divisão sexual do trabalho, trazendo com ela a fixa distinção de papéis entre o homem/provedor e a mulher/cuidadora" (Morgado, 2001: 193).
} 
Essa assertiva mostra-se pertinente quando aponta a família como uma das instâncias mediadoras entre as esferas públicas e privadas e entre os sujeitos e a coletividade. Tem como mérito, ainda, desnudar a naturalização atribuída à divisão sexual do trabalho, porém, neste fragmento, Bruschini afirma que à mulher foram atribuídos os cuidados domésticos e com a prole, a fim de resguardar a reprodução da força de trabalho. No entanto, a história do modo de produção capitalista demarca que mulheres e crianças pobres, que somente detinham como propriedade sua força de trabalho, foram inseridas nos espaços produtivos: primeiro, na manufatura; depois, na indústria. Ou seja, a afirmação da autora cabe para a mulher de segmentos sociais definidos, não para a mulher em geral.

Programas atuais da assistência social, como, por exemplo, o Programa de Erradicação do Trabalho Infantil (Peti), aparentam lidar com problemas novos e recentes quanto à exploração infantil, mas a análise rigorosa remonta a um cenário histórico de outrora.

Assim, as determinações para a apreensão dos fenômenos que incidem sobre as famílias - desemprego; déficit habitacional ou habitação precária; uso prejudicial do álcool e outras drogas; tráfico das drogas ilícitas; sofrimento psíquico etc. - requerem uma análise cuidadosa e complexa para que não se repitam as soluções empobrecedoras que reatualizam o conservadorismo na assistência às famílias. O conservadorismo ao qual se faz referência, aqui, diz respeito, justamente, àquelas propostas de intervenção que buscam responder ao sofrimento das famílias a partir de mudanças comportamentais e morais, atribuindo, em particular, às mulheres a responsabilidade maior de manter a unidade e a almejada harmonia dos núcleos familiares. Noções como 'família desestruturada e disfuncional' só pioram o quadro de empobrecimento teórico, na medida em que se tem como pressuposto a ideia de uma 'família harmoniosa, estruturada e funcional':

também é um grupo de indivíduos diferenciados por sexo e por idade, que se relacionam cotidianamente, gerando uma complexa e dinâmica trama de emoções; ela não é uma soma de indivíduos, mas um conjunto vivo, contraditório e cambiante de pessoas com sua própria individualidade e personalidade. A sexualidade, a reprodução, a socialização são esferas potencialmente geradoras tanto de relações prazerosas quanto conflitivas. A divisão interna de papéis pode ser expressão de importantes relações de dominação e submissão, na medida em que configura uma distribuição de privilégios, direitos e deveres dentro do grupo (Bruschini apud Morgado, 2001:200) 
A 'crise da família', apesar de sua configuração aparentemente recente, diz respeito a um fenômeno já evocado desde o século XIX, pela literatura, música e textos das corporações profissionais, como a medicina social. De alguma forma, as expectativas sobre a família como um espaço perfeito de higiene, de cuidado dos seus membros e de formação moral ilibada têm favorecido uma concepção de família destituída dos princípios da contradição, da história e da totalidade em certos segmentos de intelectuais, técnicos da assistência e gestores das políticas públicas.

No entanto, o século XX, em especial após a Segunda Guerra Mundial, trouxe desafios até então desconhecidos para a análise e o manejo das famílias. Podemos lembrar o movimento feminista, já a partir de meados daquele século; a aceleração dos fluxos demográficos planetários em direção aos centros econômicos; o incremento de tecnologias na biomedicina com forte impacto sobre a longevidade; e, na área de drogas, a popularização no acesso, fomentando uma epidemia de consumo etc.

Almeida menciona, como mudanças ocorridas no século passado, a

redução da constituição de novas famílias tradicionais; queda no tamanho médio das famílias; redução da taxa de fecundidade; ingresso maciço de mulheres no mercado de trabalho - movimento que não corresponde necessariamente à conquista da igualdade de condições entre homens e mulheres trabalhadores(as); alteração dos papéis familiares, ocasionada por mudanças ao nível das relações de gênero e estimulada, sobretudo, pelos movimentos feministas. Aumento de famílias constituídas por casais homossexuais; aumento dos níveis de escolarização das mulheres; crescimento das taxas de separação e divórcio; aumento das famílias monoparentais; e aumento das famílias chefiadas por mulheres. (Almeida apud Morgado, 2001:201)

Nesse cenário, de profundas mudanças no âmbito das famílias, aberto, em particular, a partir das últimas três décadas do século XX, é que vem sendo discutida, de forma improcedente, uma 'crise da família', como se mais uma vez tivesse ocorrido um desvio interno, uma disfunção provisória no roteiro esperado para essa instituição. A crise parece ser tratada de forma endógena, como se suas determinações fossem produzidas no âmbito do próprio grupo familiar, em particular, em função de alguma vulnerabilidade na formação moral e psíquica de seus membros. Com essa concepção, as propostas para a saída da 'crise' podem ganhar uma resposta individualista e moralizante. 
Assim, alguns desafios centrais para qualquer trabalhador do campo das políticas sociais públicas demandam: uma reflexão sobre o nível de complexidade que o contexto atual exige das famílias para sua reprodução material e simbólica; uma apreensão de suas manifestações atuais como um processo que não as desqualifica, mas abre um rol de potencialidades a serem exploradas; e, finalmente, uma aproximação da cotidianidade da experiência de ser família em uma conjuntura de crescimento econômico, porém, desfavorável, quando o pacto social tende a não sustentar o reconhecimento da lei.

Pellegrino (1987), lançando mão de conceitos da psicanálise, refletiu sobre a associação entre o aumento da violência e da delinquência como uma resposta ao modelo econômico vigente, que, ao precarizar e flexibilizar as relações de trabalho, produziu uma ruptura em face das expectativas futuras de bem-estar:

Assim como a aceitação da Lei da Cultura tem que abrir, para a criança, a possibilidade de ganhos fundamentais, assim também o pacto social não pode deixar de criar, para o trabalhador, direitos inalienáveis. (...) A dolorosa - e laboriosa - aquisição da competência, enquanto trabalhador, é a parte que me cabe no pacto com a sociedade. O retorno - o dá cá, resposta ao toma lá - compete à sociedade .

A ruptura com o pacto social (...) - como é o caso brasileiro - pode implicar a ruptura, ao nível do inconsciente, com o pacto edípico. (...) Um tal desastre psíquico vai implicar o rompimento da barreira que impedia em nome da Lei - a emergência dos impulsos delinquenciais pré-edípicos, predatórios, parricidas, homicidas e incestuosos. Tudo aquilo que ficou reprimido - ou suprimido - em nome do pacto com o Pai vem à tona, sob forma de conduta deliquente e antissocial. (Pelegrino, 1987:202-203, grifos meus)

\section{Conclusão}

Para finalizar o presente texto, arriscaria relacionar algumas práticas que considero importantes para os profissionais da área de álcool e outras drogas atentos ao contexto de demanda por novas práticas para a assistência à família.

O primeiro ponto a ser destacado é que é necessário desconstruir a cisão entre o usuário de drogas e sua família. É fundamental apreender a família em sua unidade - mesmo que frágil -, rompendo com a delimitação entre os 
membros que usam de forma nociva as drogas e aqueles que não as consomem. Qualquer usuário de drogas tem como identidade primária um lugar na família: ele é pai, marido, filho, mãe, esposa etc. De forma simultânea, ele é um indivíduo, sujeito único, mas parte de uma família. Portanto, mesmo que alguns dos membros possam estar sob a forte experiência do uso nocivo de substâncias psicotrópicas, as práticas assistenciais deveriam se debruçar sobre todos como família, respeitando-se as singularidades de cada sujeito.

Outro fator importante a ser considerado pelos profissionais é atentar para os múltiplos fóruns de articulação das redes de políticas sociais públicas, rompendo o histórico endogenismo das instituições dessa área. O isolamento, como condição para dar início ao tratamento dos usuários de drogas, mostrouse insuficiente e, atualmente, mostra-se anacrônico, quando o que se busca é elaborar projetos de reabilitação com vistas à liberdade e à construção da autonomia.

Como última observação, o projeto de reabilitação deve ser orientado pelos princípios da integralidade e da intersetorialidade, comumente evocados com relação às políticas sociais públicas, de forma a desenvolver nas equipes de trabalho uma atenção plural e complexa às demandas dos usuários.

Da mesma forma que o termo 'família' deve ser evocado no plural, pois se trata de muitas possibilidades de famílias, as demandas dirigidas às equipes de trabalho devem ser apreendidas de forma transversal, ou seja, elas, muitas vezes, são iniciadas a partir do sofrimento advindo do uso prejudicial do álcool e outras drogas, mas, gradativamente, se ampliam para outras áreas - trabalho, tramas familiares primárias, violência, relações conjugais instáveis etc -, evidenciando um território fértil para o (re)conhecimento das histórias singulares e coletivas inscritas nos núcleos familiares e comunitários.

\section{Referências}

BRASIL. Lei 8.742, 7 dez. 1993. Disponível em: <www.planalto.gov.br/ccivil_03/leis/ 18742.htm>. Acesso em: 18 abr. 1994.

BRASIL. Lei 10.216, 6 abr. 2001. Disponível em: <www.planalto.gov.br/ccivil_03/leis/ leis_2001/110216.htm>. Acesso em: 5 maio 2002.

BRASIL. Ministério da Saúde. Secretaria Nacional de Programas Especiais de Saúde. Divisão Nacional de Saúde Mental. Normas e Procedimentos na Abordagem do Alcoolismo. Brasília: Centro de Documentação do Ministério da Saúde, 1990. 
BRASIL. Ministério da Saúde. GM/816, 30 abr. de 2002. Disponível em:<http://dtr2001. saude.gov.br/sas/PORTARIAS/Port2002/Gm/GM-816.htm>. Acesso em: 5 mai. 2002.

BRASIL. Ministério da Saúde. Secretaria de Atenção à Saúde. A Política do Ministério da Saúde para a Atenção Integral a Usuários de Álcool e Outras Drogas. 2.ed. Brasília: Ministério da Saúde, 2004.

BRASIL. Ministério da Saúde. Secretaria de Atenção à Saúde. Departamento de Atenção Básica. Saúde da Família no Brasil: uma análise dos indicadores selecionados: 1998-2004. Brasília: Ministério da Saúde, 2006.

BRASIL. Ministério do Desenvolvimento Social e Combate à Fome. Secretaria Nacional de Assistência Social. Política Nacional de Assistência Social. Brasília: MDS, 2004.

CONSELHO REGIONAL DE SERVIÇO SOCIAL (CRESS). $7^{\text {a }}$ Região/RJ. Assistente Social: ética e direitos. Rio de Janeiro: Cress $7^{\text {a }}$ Região/RJ, 2000, (Coletânea de Leis e Resoluções).

RIO DE JANEIRO. Secretaria de Estado de Ação Social. Conselho Estadual de Assistência Social - RJ. Álbum de Fotografias Estadual. Síntese da Consolidação das Deliberações das Conferências Municipais de Assistência Social. Rio de Janeiro: Imprensa Oficial do Estado do Rio de Janeiro, 2005.

MORGADO, R. Família(s) e relações de gênero. Praia Vermelha: estudos de política e teoria social. 5: 190-215, 2001.

PELlEGRINO, H. Pacto edípico e pacto social. In: PY, L. A. et al. (Orgs.). Grupo sobre Grupo. Rio de Janeiro: Rocco, 1987.

ROUANET, S. P. Teoria Crítica e Psicanálise. Rio de Janeiro:Tempo Brasileiro, 1998.

SILVEIRA FILHO, D. X. da.\& GORGULHO, M. Dependência: compreensão e assistência às toxicomanias: uma experiência do Proad. São Paulo: Casa do Psicólogo, 1996. 
9

\title{
Empoderamento e Grupos de Mútua Ajuda
}

\author{
Tatiana Rangel Reis
}

Neste capítulo, pretendemos apresentar e analisar a perspectiva de apoio oferecida pelos grupos de mútua ajuda, que representam, na atualidade, em nosso país e no mundo, alternativas viáveis e eficazes para diversas questões presentes na sociedade, em geral, situações de sofrimento psíquico geradas por comportamentos compulsivos.

O capítulo encontra-se dividido em quatro partes: na primeira, abordaremos o conceito de empoderamento, já que é à luz do mesmo que efetuaremos a análise dos referidos grupos; na segunda parte, apresentaremos a filosofia dos grupos de mútua ajuda propriamente ditos com base no modelo que constituiu a matriz de todos os demais, os Alcoólicos Anônimos (AA), seguida da exemplificação de grupos direcionados para outros objetivos; na terceira parte, analisaremos alguns dos principais ganhos e limitações existentes no interior desses grupos, sob a ótica do empoderamento.

\section{Breves Considerações sobre o Conceito de Empoderamento}

Segundo Vasconcelos (2003), o termo 'empowerment', próprio da literatura anglo-saxônica e de difícil tradução direta para o português, pode ser entendido, ao mesmo tempo, como ‘empoderamento’ (já utilizado em nosso país), 
'fortalecimento' e 'autonomia'. No entanto, por considerar que nenhuma das traduções seja satisfatória, o autor utiliza, por vezes, o termo em inglês, exatamente para manter o caráter complexo do conceito. Aqui, utilizaremos a tradução mais imediata que é empoderamento. Uma das denominações possíveis para esse conceito apresentada por Vasconcelos é:

Aumento do poder e autonomia pessoal e coletiva de indivíduos e grupos sociais nas relações interpessoais e institucionais, principalmente daqueles submetidos a relações de opressão, dominação e discriminação social. (Vasconcelos, 2003: 20)

Em face da complexidade e do caráter multifacetado desse conceito, Vasconcelos também salienta que ele pode ser apropriado por diferentes abordagens e leituras teóricas, das mais críticas e progressistas às mais conservadoras, dependendo dos diferentes grupos e sujeitos sociais que o utilizarão. Logo, de acordo com o projeto societário assumido, o empoderamento pode gerar situações de opressão ou de autonomização e fortalecimento individual/grupal. No caso de gerar situações de opressão ou discriminação, Vasconcelos chega a mencionar a possibilidade de ocorrer um 'desempoderamento', ou seja, uma perda da autonomia de indivíduos e grupos sociais envolvidos.

A literatura sobre o tema e suas apropriações no campo social e da saúde pode apresentar diferentes sentidos e perspectivas ideopolíticas, assim como acontece com conceitos como os de 'participação', 'conscientização', entre outros, que também guardam um caráter dúbio (Vasconcelos, 2007). De um modo geral, a perspectiva aqui assumida de empoderamento é a de um conjunto de estratégias capazes de promover o fortalecimento do poder, da autonomia e da auto-organização de usuários e familiares de serviços de saúde e, mais especificamente, de saúde mental, em se tratando dos usuários de álcool e outras drogas, seja no plano pessoal, grupal, ou institucional (Vasconcelos, 2007).

Do mesmo modo, as abordagens de empoderamento apresentam diferentes perspectivas, seja no âmbito das instituições formais de atendimento (nas quais é o profissional quem busca estimular o empoderamento entre os usuários dos serviços), seja no âmbito da busca pelo autoempoderamento em nível individual, grupal, comunitário e na militância social (Vasconcelos, 2007). No caso dos grupos de mútua ajuda, podemos dizer, então, que estamos diante de uma estratégia autonomista de autoempoderamento individual e grupal, já que tais grupos são organizados e mantidos pelos próprios membros, sendo autônomos 
em relação aos profissionais, de um modo geral, especialmente os profissionais da área 'psi'.

Para Vasconcelos (2003), as perspectivas de empoderamento encontram-se, muitas vezes, relacionadas a culturas e a formas de organização social mais autonomistas, dada a experiência do autor com os movimentos de usuários de saúde mental e seus familiares em países anglo-saxões, o que não impede a apropriação desse conceito para a realidade brasileira. No Brasil, particularmente, estamos lidando com uma cultura hegemonicamente hierárquica e patrimonialista, que sempre estimulou a dependência e os laços pessoais com o Estado, bem como com os profissionais e serviços destinados à população. Os grupos de mútua ajuda, por sua vez, colocam-se em uma perspectiva mais autônoma e terminam rompendo, em parte, com essa lógica da dependência exclusiva do Estado e dos serviços de saúde por ele oferecidos. ${ }^{1}$

Dentre os conceitos importantes e que espelham ao mesmo tempo diferentes estratégias de empoderamento, citamos os seguintes: ajuda mútua, suporte mútuo, defesa de direitos (advocacy), transformação do estigma e da dependência na relação com a loucura e o louco na sociedade (e por que não dizer, também, por exemplo, na relação com os indivíduos alcoolistas na sociedade), participação mais ampla no sistema de saúde/saúde mental e militância social e política.

A ajuda mútua é um tipo de prática conhecida a partir dos grupos de AA, que trocam experiências, vivências e ajuda emocional em torno de um problema comum. Esses grupos possuem uma organização autônoma, na qual a história de cada membro é valorizada como um caminho para o outro buscar suas próprias soluções e enfrentar seus desafios. Além dos grupos, outras manifestações menos convencionais da mútua ajuda podem ocorrer por meio dos grupos de amigos com os quais podemos compartilhar constantemente dores, vitórias e derrotas, os chamados 'amigos-irmãos', além das páginas pessoais na Internet, blogs, salas de bate-papo, dentre outras alternativas, em que as pessoas podem compartilhar experiências de vida comuns (Vasconcelos, 2003).

Com base nos dispositivos mais padronizados de ajuda mútua, podem ser desenvolvidas atividades de iniciativas concretas de cuidado e suporte na vida das pessoas. Essas atividades podem ser das mais simples, como ajudar outro

\footnotetext{
1 Para maior aprofundamento em torno das diferenças existentes entre os países de cultura hegemonicamente individualista, como os de origem anglo-saxã, e os países de cultura predominantemente hieráquica, ver: Carnavais, Malandros e Heróis (DaMatta, 1983) e Individualismo e Cultura (Velho, 2004).
} 
membro do grupo a realizar suas compras, cuidar da casa, sair para alguma atividade de lazer, até as mais complexas, como o desenvolvimento de projetos relacionados a questões de moradia e trabalho para os indivíduos que apresentam demandas nessas áreas, elaboração de cartilhas informativas, entre outras atividades que caracterizam o suporte mútuo. Para Weingarten (2001), o suporte mútuo implica, então, a reunião de usuários com o propósito de realizar conjuntamente uma tarefa ou um serviço.

A partir do suporte mútuo, é possível avançar ainda mais para a perspectiva de defesa de direitos (advocacy), que pode se dar em dois níveis: um primeiro nível de autodefesa, no qual um usuário ou membro de um grupo de mútua ajuda é estimulado e capacitado a defender seus direitos, em casos de algum tipo de discriminação ou violência sofrida (por exemplo, um paciente portador do vírus HIV impedido de obter trabalho); e um segundo nível mais formal de defesa de direitos, que inclui a formação de serviços com parcerias entre profissionais de saúde mental, por exemplo, e advogados para defender os direitos civis, políticos e sociais dos envolvidos. Esse nível do empoderamento inclui, ainda, a elaboração conjunta de cartas de direitos, normas de serviços, legislação que contemple os direitos dos interessados, entre outras ações que constituam a defesa de direitos.

Como última estratégia de empoderamento a ser descrita aqui, encontra-se a transformação do estigma e a militância social e política mais ampla. Embora, em seu livro, Vasconcelos (2003) as tenha mencionado separadamente, aqui, para fins didáticos, uniremos as duas perspectivas. Essa vertente engloba diversas iniciativas sociais e culturais para mudar atitudes discriminatórias em relação a quaisquer grupos oprimidos socialmente, como, por exemplo, os grupos de alcoolistas, os dependentes químicos de um modo geral, os portadores de transtorno mental, entre outros. A mudança no modo de nomear grupos minoritários (por exemplo, de 'paciente' com 'doença mental' para 'usuário' e 'portador de transtorno mental ou sofrimento psíquico') e a produção de programas para a mídia que abordem o problema da discriminação são algumas das iniciativas tomadas nessa direção.

No campo da participação política e militância social, podemos considerar a participação dos usuários em movimentos mais amplos de luta pelos seus interesses. No caso do sofrimento psíquico/transtorno mental, pode-se ressaltar a participação dos usuários no Movimento da Luta Antimanicomial (Vasconcelos, 2003). 
Vistos os principais conceitos envolvidos nas estratégias de empoderamento, nos deteremos, a seguir, mais detalhadamente, na filosofia e em alguns princípios dos grupos de mútua ajuda, além de apresentarmos as diferentes modalidades de grupos existentes atualmente.

\section{Uma Análise dos Grupos de Mútua Ajuda baseada em sua Matriz Básica: Alcoólicos Anônimos}

Além da conceituação de ajuda mútua já abordada, outra definição pode ser destacada:

A ajuda mútua baseia-se no princípio de que a reunião de pessoas que partilham uma mesma condição ajuda-os a lidar com suas situações de dependência. O dar e receber mútuo é considerado como uma ação terapêutica. O compartilhar de experiências, sentimentos e formas práticas no manejo de problemas ajuda as pessoas a melhorar e lidar melhor com a vida, através do reconhecimento de seus sentimentos, enfim, de seu mútuo empowerment. (Tosh et al. apud Weingarten, 2001:24)

Percebe-se, pelo exposto, que o elemento mais importante e que identifica um grupo como sendo de mútua ajuda é o problema comum que une seus membros, ou seja, o objetivo da reunião é se ajudar mutuamente, pois, todos ali, de uma forma ou de outra, possuem experiências com uma situação específica, e compartilhando-as com o grupo podem encontrar estratégias comuns de enfrentamento do problema. Ou, como acentuou Mascarenhas (1990), são pessoas que, por já terem sentido "na carne" um problema, podem ajudar melhor outras que vivem situações semelhantes. Segundo Weingarten, sete milhões e meio de norte-americanos (segundo dados até 2001) eram integrantes de cerca de quinhentos mil grupos de ajuda mútua a cada ano.

O primeiro grupo de ajuda mútua nasceu, em 1935, em Akron, nos Estados Unidos, quando duas pessoas que passavam por graves problemas relativos ao uso abusivo de bebidas alcoólicas se reuniram e começaram a conversar sobre suas dificuldades. Estava fundada a Irmandade de Alcoólicos Anônimos (AA), organização esta que hoje conta com mais de dois milhões de membros, espalhados em cerca de 180 países. Como se explica tamanhas 
difusão e longevidade (o AA possui 77 anos de existência no mundo e 65 anos de vida no Brasil)?

Segundo a literatura dessa organização, e também pelo que foi constatado pela pesquisa participante efetuada durante o curso de doutorado em serviço social, o AA apresenta uma organização e uma estrutura de filiação descentralizadas e de base, sendo que os grupos constituem a célula básica. O anonimato absoluto é garantido a seus membros. Além disso, trata-se de uma organização autossuficiente, na qual seus membros não aceitam doações de fora. Assim, durante as reuniões, eles próprios dão uma contribuição em dinheiro, voluntária, visando à manutenção da irmandade. A dinâmica das reuniões, no tocante a horários e dias de funcionamento das salas, varia de acordo com os grupos. Somente no município do Rio de Janeiro existem cerca de duzentos grupos, espalhados em diversos bairros e zonas da cidade.

As reuniões têm a duração de duas horas, e cada membro possui cerca de dez minutos para falar de si mesmo, sem se remeter aos problemas dos outros participantes, ou apresentar conselhos de qualquer tipo (ou, como costumam dizer, 'retornos' a quem quer que seja). Para ingressar em AA, não é preciso fazer inscrição ou pagar qualquer taxa, apenas ter o 'sincero desejo de parar de beber'. Aos novatos, é passado o Programa de Recuperação, mais conhecido como Os Doze Passos (no Anexo deste capítulo), que deverá acompanhar o membro de AA durante toda a sua vida. O primeiro e mais difícil passo é o indivíduo aceitar que 'perdeu a batalha' para o álcool e que, consequentemente, perdeu também o domínio de sua vida. A partir daí, é 'sugerido' ao membro acreditar em um 'poder superior' a si próprio, a quem ele deverá 'entregar sua vida e sua vontade', pedindo forças para lidar com a compulsão, através da 'remoção' de determinados 'defeitos de caráter', como o 'egocentrismo, o orgulho e a vaidade', que podem estar na base da sua 'doença alcoólica'.

Como o AA não é uma entidade religiosa, costuma-se dizer que esse 'poder superior' pode ser o próprio grupo ou qualquer outra representação a ser escolhida pelo membro, além, é claro, da própria ideia de Deus, que aparece em alguns dos doze passos. Além dos passos, existem as doze tradições e os doze conceitos responsáveis pela manutenção e organização da irmandade como um todo. ${ }^{2}$

2 Para maior aprofundamento sobre os programas Doze Passos, Doze Tradições e Doze Conceitos de AA, sugiro a leitura dos seguintes livros elaborados nos Estados Unidos e traduzidos para vários países: Os Doze Passos e as Doze Tradições (Junaab, 2004) e Doze Conceitos para Serviços Mundiais (Junaab, 1999). Toda a literatura de AA encontra-se disponível para venda nos 
O alcoolismo, para os membros de AA, é uma 'doença física, mental e espiritual'. Portanto, a resolução do problema não pode se dar sem um olhar direcionado para essas instâncias, especialmente a espiritual, no importante momento em que ocorre para o membro um 'despertar espiritual', ou melhor dizendo, um estágio de 'rendição' em que o sujeito percebe não possuir mais o controle de sua existência, necessitando entregá-la ao 'poder superior', partilhando sempre seus momentos de angústias e conquistas nas reuniões de AA. Para o membro ingressante, por exemplo, existe o lema "90 dias, 90 reuniões", pelo fato de os três primeiros meses serem considerados os mais difíceis na recuperação. Além desses, outros importantes lemas constituem a chave da recuperação em AA: "evite o primeiro gole", "só por hoje", "vá com calma", "primeiro as coisas primeiras", dentre outros.

Outro momento importante da reunião é quando os membros do grupo fazem em conjunto a oração ou evocação da serenidade (como preferem chamar os membros ateus ou agnósticos), a fim de obterem forças para sua recuperação. ${ }^{3}$ Além da oração, outros fatores que contribuem no processo de manutenção da abstinência são as mudanças dos 'hábitos da ativa', como o afastamento dos amigos com os quais se costumava beber, o afastamento dos locais onde se costumava beber, o acesso à literatura da irmandade, que contém, segundo enfatizam seus membros, todas as respostas para as dúvidas que um membro de AA possa ter, dentre outros.

Por serem compostos, organizados e dirigidos pelos próprios membros, os grupos apresentam uma dinâmica horizontalizada, em que um não deve se sentir superior ao outro, pois todos ali 'estão no mesmo barco', buscando uma saída para problemas comuns, não havendo divisão entre aquele que presta ajuda e o que a recebe. Em AA, isso fica claro durante as reuniões, quando pudemos perceber acolhimento e receptividade para todos os membros, tanto para os que estivessem chegando quanto para os participantes mais antigos.

Outra característica positiva de grupos de mútua ajuda como o AA é a acessibilidade. Esses grupos estão presentes em todo o mundo, com salas abertas nos mais diferentes horários, representando alternativas eficazes aos serviços usualmente fornecidos à população. Em nossa pesquisa no AA do Rio de

grupos e também no Escritório de Serviços Locais de AA do Rio de Janeiro (cada estado tem esse tipo de escritório), localizado na Avenida Rio Branco, $57-2^{\circ}$ andar.

3 Oração ou evocação da serenidade: "Concedei-me, Senhor, a serenidade necessária para aceitar as coisas que não posso modificar, coragem para modificar aquelas que posso e sabedoria para distinguir umas das outras". 
Janeiro, por exemplo, tomamos conhecimento da existência de um grupo no ponto mais alto do Complexo do Alemão, uma comunidade conhecida pelos altos índices de violência. Nesse local perigoso e de difícil acesso, não se tem conhecimento da existência de um serviço de atendimento estatal, voltado para pessoas com problemas de alcoolismo, mas há, no entanto, um grupo de AA.

Outros grupos de AA também abrem suas salas em períodos considerados preocupantes para o alcoolista, como as festas de fim de ano e o carnaval, quando o apelo ao consumo de bebidas alcoólicas torna-se ainda maior. Existem até grupos nos quais os membros, se quiserem, podem passar a noite de Natal em reunião com outros 'companheiros', durante a qual terão a oportunidade de fazer, em grupo, uma pequena ceia.

Por não haver requisitos para o ingresso, apenas o fato de o indivíduo estar tendo problemas com o álcool (no caso de AA), tais grupos são acessíveis também para pessoas de diferentes classes sociais, não havendo exigência de escolaridade. O que costuma acontecer é que os membros acabam escolhendo certos grupos em que se sentem mais à vontade, e tal escolha geralmente obedece a critérios de classe, de poder aquisitivo, proximidade de sua moradia, entre outros fatores. Isto é, as pessoas acabam buscando os grupos não apenas por uma identificação quanto ao alcoolismo, mas também no tocante a outras variáveis.

Embora não seja uma terapia de grupo (que requereria níveis mais aprofundados de mergulho nas questões psicológicas, e isso não é o que acontece nessas reuniões), os estudiosos consideram que os grupos de mútua ajuda proporcionam uma ação terapêutica ou, ainda, que existem, nesses grupos, certos fins terapêuticos, a partir do momento que determinados ganhos podem ser observados entre seus participantes. Com base em sua experiência com grupos de ajuda mútua nos Estados Unidos, Weingarten afirma que, apesar de não haver muitos estudos estatísticos sobre a efetividade desses grupos, existem alguns benefícios que podem ser considerados, como: melhor relacionamento dos membros com os outros; maior responsabilidade; melhor vínculo com os companheiros do grupo; mais assertividade; capacidade para tomar suas próprias decisões; estilo de vida mais independente; melhor capacidade em escutar; melhora na solução de problemas; aumento da autoestima; mais esperança no futuro; e uma sensação de bem-estar (Weingarten, 2001).

Muito embora, conforme já mencionamos, o AA e os demais grupos de mútua ajuda mantenham uma independência em relação aos profissionais e serviços em geral, em especial os profissionais da área da saúde e saúde mental, seus 
membros, em particular, não rejeitam ou descartam o uso pessoal e privado de tratamentos profissionais, como, por exemplo, as psicoterapias individuais realizadas paralelamente à frequência aos grupos. Além disso, é comum existirem atividades de cooperação entre o AA e os demais grupos de mútua ajuda com esses profissionais, já que grande parte dos médicos, psicólogos, psiquiatras e assistentes sociais têm indicado os grupos de mútua ajuda para os usuários de seus serviços. ${ }^{4}$

O AA apresenta algumas ramificações como o Al-Anon, voltado para familiares de alcoolistas (esposas, irmãos etc), e o Al-Ateen, voltado para filhos adolescentes de alcoolistas, uma vez que o alcoolismo é considerado uma 'doença da família', em que todos os membros necessitam de ajuda.

Baseadas nos grupos de AA, outras organizações de mútua ajuda surgiram nos Estados Unidos, com ramificações em vários países, dentre eles, o Brasil, seguindo a mesma lógica de funcionamento e princípios fundamentais do AA, adequando seus conteúdos segundo a problemática de fundo. A seguir, apresentaremos, de forma resumida, alguns desses grupos de mútua ajuda existentes no Brasil. $^{5}$

NeuRóticos Anônimos (N.A.): "é uma irmandade formada por homens e mulheres que compartilham suas experiências, fortaleza e esperança para resolverem seus problemas emocionais comuns e dessa forma se reabilitarem da doença mental e emocional. Para ser membro desta irmandade basta considerar-se uma pessoa neurótica, ou seja, com perturbações emocionais". ${ }^{6}$

NARCóticos AnÔNimos (N.A.): representam os grupos mais próximos do AA, por lidarem com questões referentes à adicção às drogas ilícitas, como cocaína,

\footnotetext{
4 É importante mencionar que, uma vez ao mês, realiza-se no Escritório de Serviços Locais de AA, no Rio de Janeiro, a Reunião de Informação e Cooperação com os Profissionais, da qual participei ativamente no período de 2004 a 2007. O que se percebe é um número crescente de profissionais da área da saúde e saúde mental que comparecem a essas reuniões com o intuito de efetuar parcerias de apoio mútuo, realizado mediante o encaminhamento de seus pacientes usuários para os grupos de AA e, também, a presença de membros do AA em seus locais de trabalho, relatando suas experiências concretas de longos anos no enfrentamento do alcoolismo.

5 No tocante aos princípios dessas outras irmandades, notamos a existência de variações: algumas falam em Doze Passos, Doze Tradições, mas não em Doze Conceitos; outras falam em Doze Passos, Doze Tradições e em Sete Lemas, que também seriam princípios auxiliares da recuperação, mais voltados para o cotidiano dos seus membros, entre outras variações. O que pudemos perceber, no entanto, de mais recorrente, foram os Doze Passos adaptados do AA para cada tipo de 'compulsividade' trabalhada pelos demais grupos. A oração da serenidade, no entanto, é a mesma em todas as irmandades. Para maior aprofundamento, sugiro a literatura pertinente a cada uma delas, encontrada nos próprios grupos.

6 Informações retiradas do site <www.neuroticosanonimos.org.br
} 
maconha, LSD, entre outras. Diz-se que são os mais próximos de AA, pois muitos dependentes químicos utilizam essas drogas associadas ao álcool, daí o fato de alguns membros frequentarem, ao mesmo tempo, o AA e o N.A. Possui também uma ramificação destinada aos familiares denominada Nar-Anon.

Jogadores AnÔnimos (J.A.): irmandade destinada aos indivíduos compulsivos por quaisquer tipos de jogos. O jogo compulsivo é considerado "uma doença progressiva, que não se pode curar, porém pode ser detida". ${ }^{7}$ Existe ainda uma ramificação para os familiares, parentes e amigos próximos que são também afetados pelo problema do jogo, o Jog-Anom.

Devedores Anônimos (D.A.): irmandade fundada nos Estados Unidos, em 1967, e, no Brasil, em 1997, para ajudar pessoas na recuperação do endividamento compulsivo. Trata-se de um programa "para auxiliar pessoas que sofrem da oneomania (do verbo onerar, pessoa que gera muitos gastos). O D.A. tem o propósito de ensinar seus membros a reaprender a lidar com o dinheiro e, para isso, realizam cálculos das despesas domésticas e os relacionam com os ganhos mensais da pessoa".

Fumantes AnÔnimos (F. A.): "é uma irmandade de pessoas que sentiram o poder da adicção à nicotina (...). Nosso propósito primordial é ajudarmos outras pessoas e nós mesmos a viver sem fumar". ${ }^{9}$

Comedores Compulsivos Anônimos (C. C. A.): fundada nos Estados Unidos em $1960,{ }^{10}$ o CCA, reconhecendo a incapacidade de alguns indivíduos para controlar o comer compulsivo, oferece ao recém-chegado apoio para lidar com os sintomas físicos e emocionais desse comportamento.

Mulheres que Amam Demais Anônimas (Mada): fundada no Brasil em 1994, "Mada é uma irmandade de mulheres que compartilham sua experiência, força e esperança, para resolver problemas comuns e ajudar outras mulheres a se recuperarem de sua dependência de pessoas", ${ }^{11}$ em especial a dependência de relacionamentos destrutivos com homens ou com quaisquer outras pessoas (familiares, amigos, entre outras).

Dependentes de Amor e Sexo Anônimos (Dasa): em inglês, SLAA, Sex and Love Addicts Anonymous. Fundada, em Boston (Estados Unidos), no ano de

\footnotetext{
Informações retiradas do site www.jogadoresanonimos.org

Informações retiradas de <www.devedoresanonimos.rj.cjb.net>.

Informações retiradas de < www.fumantesanonimos.org $>$.

10 Em alguns sites, não obtivemos a data precisa do surgimento das irmandades no Brasil, no entanto, sabemos que todas aqui explicitadas existem em nosso país, sobretudo nos grandes centros urbanos. Nos sites específicos, são apresentados os endereços por capital do Brasil.

11 Informações retiradas de <www.grupomada.com.br.>
} 
1976, a "Dasa é uma irmandade de ajuda mútua, aberta a todas as pessoas de qualquer idade e inclinação sexual. Dentre seus membros, encontram-se tanto os que experimentaram uma necessidade compulsiva de sexo, como aqueles com um apego desesperado a uma única pessoa. Todos os membros têm um padrão comum de comportamento obsessivo/compulsivo, seja sexual como emocional (ou ambos)" e lidam com a dependência "por sexo, amor, relacionamentos românticos, emocionais e de anorexia sexual, social e emocional".

CODEPENDENTES ANÔNimos (CODA): é "um programa de recuperação para a codependência, onde cada um de nós pode compartilhar da nossa experiência, força e esperança, em nossos esforços para nos libertarmos da escravidão e confusão das nossas relações com outros e com nós mesmos (...). Constatamos que, em nossas vidas, a codependência é um comportamento compulsivo profundamente arraigado e que nasce, por vezes, em famílias com sistemas extremamente disfuncionais e em outros casos não". ${ }^{12}$

Sobreviventes de InCESTo AnÔNimos (SAI): irmandade que "ajuda homens e mulheres que foram vítimas de abuso sexual na infância”. ${ }^{13}$

Portanto, assim como o AA, a matriz de todos os grupos de ajuda mútua, essas irmandades organizam-se da seguinte forma: são autossuficientes, possuem uma estrutura de funcionamento que permite o acesso a qualquer pessoa, independente de raça, classe social, idade ou sexo, e também apresentam uma literatura que vem dos Estados Unidos, denotando a existência de uma verticalização na doutrina e no tipo de organização mais geral (apesar da horizontalidade nas relações entre os seus membros), o que tem garantido sua rápida disseminação em vários países do mundo, com um grau relativamente simples de funcionamento.

A seguir, destacaremos mais alguns benefícios propiciados por esses grupos de mútua ajuda e apresentaremos, também, algumas das principais limitações que, no nosso entendimento, envolvem essas organizações.

12 Informações retiradas de <www.codependentes.freeyellow.com>

13 Informações retiradas de <www.slaa.org.br. Nos Estados Unidos, podem ser encontrados, ainda, inúmeros outros grupos de mútua ajuda voltados para os mais diversos tipos de problemas, como: Maryjuana Anonymous, Workaholic Anonymous, Emotions Anonymous, ObsessiveCompulsive Anonymous, Shopaholis Anonymous (pessoas dependentes de shopping-centers), entre outros (Reinarman apudVasconcelos, 2003). 


\section{Possibilidades e Limites dos Grupos de Mútua Ajuda}

Autores como Vasconcelos (2003), Mota (2004) e Reinarman (apud Vasconcelos, 2003), entre outros, tratam do tema da Irmandade de AA (e estamos propondo aqui associar suas análises a outras, que enfocam os demais grupos de ajuda mútua), buscando evidenciar determinados aspectos 'positivos', do ponto de vista de sua eficácia na recuperação do alcoolismo, e também certos aspectos críticos à irmandade, do ponto de vista da autonomização do sujeito e, também, da viabilidade ou não, no interior dessa organização, de uma visão social e política mais ampla do fenômeno do alcoolismo, menos vinculada ao registro médico, entre outras ressalvas.

Longe de efetuarmos aqui uma leitura maniqueísta dessas irmandades, em torno do que elas apresentam de bom ou ruim, acreditamos que considerações a respeito do que a literatura tem apontado sobre os grupos de mútua ajuda (em especial o AA, que representa a matriz de todos os demais), seja de ganhos ou limitações, representam uma tarefa importante para profissionais da área de saúde e saúde mental, que lidam diretamente com as complexas situações para as quais tais grupos buscam oferecer uma estratégia de recuperação. Enfocaremos, então, o que foi problematizado sobre os grupos de AA, sem deixarmos, contudo, de ter com outras irmandades, sobre as quais não há uma avaliação mais sistematizada, uma interlocução.

Se, por um lado, alguns autores percebem a organização de AA como um importante dispositivo capaz de oferecer solidariedade e ajuda mútua para os que sofrem com a problemática do alcoolismo, por outro lado, notam, como uma de suas limitações, a forte conotação individualizante, ou seja, é o próprio indivíduo que se torna o responsável pelo sucesso ou fracasso de seu processo de recuperação, em virtude da pouca ou nenhuma consideração dos aspectos políticos, sociais e econômicos que determinam a existência do alcoolismo nas sociedades. Isto é, segundo a lógica interna do AA, o alcoolismo seria tão somente uma doença, não havendo nenhuma causa social em sua origem (Mota, 2004). Também, segundo Reinarman:

O movimento dos Doze Passos parece (...) inverter a imaginação sociológica de C. Wright Mills: ao invés de transformar problemas privados em questões públicas ou pelo menos ligar as duas, a ideologia dos Doze Passos tende a desligar esse vínculo ou a transformar o que pode ser entendido 
como questões públicas em problemas privados. (Reinarman apud Vasconcelos: 2003: 91)

Com base nessa citação, podemos perceber ainda mais a complexidade do tema em questão, considerando-se a polêmica e debate que tem suscitado na cena contemporânea. A seguir, apontamos uma sistematização, elaborada por Vasconcelos (2003), relativa a determinados 'ganhos' propiciados por AA, e os aspectos que constituem 'limites', na opinião desse autor, relativos à dinâmica de funcionamento e ideologia/filosofia dessa irmandade.

Assim, na perspectiva das abordagens do empoderamento, os 'ganhos' do tipo de 'recuperação', propostos em AA, seriam:

a) AA apresenta uma organização e estrutura de filiação completamente descentralizadas e de base, sem mandato de autoridade superior sobre a autonomia dos grupos. Os grupos de AA constituem a principal 'mola propulsora' desta irmandade; tudo deve passar pelo consenso coletivo do grupo;

b) em AA existe uma proibição explícita de acumulação de dinheiro, propriedade e prestígio. Logo, os membros não são donos das salas onde acontecem as reuniões. Estas são, geralmente, alugadas ou cedidas. Os participantes também não são 'donos' dos grupos, ou seja, os cargos de coordenação de grupo, tesoureiro, entre outros, são sempre ocupados sob a forma de rodízio, para que as pessoas não tenham chances de se perpetuar no 'poder';

c) as reuniões em AA baseiam-se em um forte processo de valorização da história pessoal de cada membro e de aprendizagem grupal. O que os une é o sentimento de que, independente da vida de cada um, todos ali estão vivenciando a luta contra uma problemática comum: o alcoolismo;

d) em AA, há uma garantia de absoluto anonimato para os membros que frequentam as reuniões em relação ao mundo fora dos grupos;

e) em AA, no processo de recuperação, o indivíduo consegue recompor certos laços e vínculos sociais fortemente comprometidos por causa do alcoolismo, como o vínculo familiar, social e de trabalho, entre outros.

Ainda na perspectiva do empoderamento, para Vasconcelos (2003), as principais limitações dos grupos de AA seriam: 
a) seus elementos de inspiração religiosa baseados no individualismo protestante (dada a sua origem norte-americana) terminam por colocar, no próprio indivíduo, a responsabilidade sobre o sucesso ou fracasso no 'combate' ao alcoolismo;

b) o fato de o alcoolismo ser considerado uma doença progressiva, incurável e fatal (mesma denominação utilizada em outros grupos de mútua ajuda no tocante às respectivas 'doenças' por eles trabalhadas), ao mesmo tempo que contribui para 'não culpabilizar' o alcoolista e sua família da culpa moral (o indivíduo é doente e não imoral), também aprisiona os problemas relacionados ao alcoolismo restritos a um registro médico, no sentido mais convencional da medicina ocidental, não deixando espaços para o diálogo com outras áreas de conhecimento que seriam extremamente frutíferas para o entendimento desse fenômeno, como a sociologia, a psicologia, a antropologia, entre outras;

c) quaisquer abordagens no interior das reuniões que mencionem aspectos sociais, estruturais, políticos e culturais que influenciam o ato de beber tendem a ser vistas como 'questões externas à irmandade' e, portanto, não merecedoras de atenção. Além disso, na maioria das vezes, tais considerações são excluídas sob a alegação de serem 'desculpas' ou 'negação' do indivíduo, que não quer tomar para si a responsabilidade sobre a prática do programa de recuperação;

d) as práticas grupais em AA, tendo em vista o seu modelo de reunião padronizado, ao não abrirem espaço para o risco e o imprevisível, não seriam estimuladoras de processos de autonomização psicológica, criatividade e pluralismo cultural;

e) apesar de ser um dispositivo de ajuda mútua, o sujeito permaneceria fechado na estrutura institucional, não havendo, consequentemente, espaço para iniciativas de suporte mútuo, defesa dos direitos sociais ou ações de transformação do estigma e militância social no tocante ao tema do alcoolismo na sociedade (Vasconcelos, 2003).

Apesar das divergências sobre os ganhos e os limites existentes nessas irmandades, Reinarman (apud Vasconcelos, 2003) levanta uma importante hipótese para a larga difusão da cultura dos Doze Passos na atualidade: na sua concepção, tais irmandades oferecem aos seus membros uma clara cosmologia, ou seja, uma visão de mundo que lhes fornece um sentido de acolhimento 
e de pertencimento, difíceis de serem encontrados em sociedades fragmentadas, como são as modernas sociedades ocidentais, nas quais as identidades encontram-se descentradas, gerando instabilidade subjetiva e insegurança nas relações interpessoais. Desse modo, corroborando o pensamento desse autor, julgamos que tais grupos representam espaços concretos nos quais os indivíduos podem viver ou reviver, de algum modo, laços de comunidade, uma vez que vivenciam e partilham problemas e experiências comuns, o que leva à diminuição do sentimento de solidão e de impotência diante da vida.

\section{Considerações Finais}

O próprio Vasconcelos (2003), ao elencar tais considerações sobre a irmandade de AA, foi cauteloso e respeitoso quando salientou que muitos autores e militantes da área de saúde mental não concordam com as críticas por ele levantadas, por considerarem-nas 'irrealistas e teóricas' para a dinâmica possível de ajuda mútua construída em AA.

De qualquer forma, partilhamos da ideia de que todo grupo social organizado, a partir do momento que passa a ser objeto de estudos e debates, mostra suas possibilidades e limites mais profundos, suas contradições e fragilidades, que na verdade são comuns em qualquer organização humana.

Com base em nossa pesquisa participante ${ }^{14}$ realizada entre 2004 e 2007, em grupos de AA no Rio de Janeiro, podemos dizer que concordamos com os aspectos positivos e as limitações apontadas anteriormente. Concordamos também com o fato de que, sem sombra de dúvida, o AA representa, hoje, um dos dispositivos mais eficazes no tratamento do alcoolismo, considerado um grave problema de saúde pública. ${ }^{15}$ Sendo assim, não podemos deixar igualmente de atribuir a devida importância aos demais grupos de mútua ajuda.

Cabe a nós, então, como profissionais da saúde, lidarmos com essas irmandades do ponto de vista do que elas têm a oferecer de ajuda para milhares de pessoas. Sob a ótica de outras necessidades geradas por situações de opressão

14 O resultado da pesquisa é a tese de doutorado intitulada Fazer em Grupo o que Eu Não Posso Fazer Sozinho: indivíduo, grupo e identidade social em Alcoólicos Anônimos, defendida e aprovada em outubro de 2007, na Universidade Federal do Rio de Janeiro (UFRJ).

15 De acordo com os dados obtidos no I Levantamento Domiciliar sobre o Uso de Drogas Psicotrópicas no Brasil (Cebrid, 2001), 11,2\% dos brasileiros já desenvolveram o estágio de dependência do álcool. 
social (tais como demandas por moradia, trabalho, discriminação, falta de legislação adequada para lidar com a questão, entre outras), sabemos que, dificilmente, as respostas para essas questões serão encontradas em grupos de mútua ajuda, tal como estes se encontram estruturados hoje em dia.

Acreditamos que as saídas para essas situações conflitantes poderão ser estimuladas e procuradas em outros dispositivos associativos voluntários estruturados de modo diferenciado dos grupos de mútua ajuda tradicionais e, também, na rede de serviços oferecidos à população de um modo geral, numa perspectiva que Vasconcelos chama de 'complementação aos grupos de ajuda mútua'. Isto é, trata-se de pensar em outras iniciativas que poderiam caminhar paralelamente às já tradicionalmente conhecidas e que estimulariam, então, estratégias mais aprofundadas de empoderamento, no tocante aos dilemas individuais, grupais e comunitários, vistos sob um enfoque ampliado (Vasconcelos, 2007).

Quanto à irmandade AA, sabemos da sua firmeza, no tocante aos pilares mais fundamentais da ajuda mútua, e da sua fragilidade, quanto aos demais dispositivos de empoderamento, como o suporte mútuo, a defesa de direitos, a transformação do estigma e a militância social. Ainda assim, consideramos que algumas iniciativas de suporte mútuo que contribuem para a transformação do estigma podem ser percebidas no interior dessa organização. São elas a 'linha de ajuda', as palestras de informação ao público e os programas na mídia.

A linha de ajuda é um dispositivo pelo qual os membros de AA, voluntariamente, pelo regime de plantão, colocam-se à disposição para fornecerem, por telefone, ajuda aos que precisem, disponibilizando, principalmente, endereços de grupos de AA próximos das residências dos prováveis ingressantes, bem como endereços de grupos de Al-Anon, para os familiares, ou de outros grupos de mútua ajuda (como N.A ou J.A) para pessoas com diferentes tipos de problemas.

As palestras de informação ao público são dadas pelos membros mais experientes de AA (geralmente os que estão há mais tempo em recuperação), em escolas, empresas, hospitais, entre outras instituições, quando solicitados. Nessas palestras, além de explicar o que é o alcoolismo e como ele se manifesta, o membro de AA aproveita para, indiretamente, convidar prováveis membros para participarem da irmandade (no caso, aqueles que sintam que o que foi abordado na palestra se assemelha ao que estejam vivenciando). Acreditamos ainda que as palestras contribuam para transformar o forte estigma de que o "alcoolismo é apenas falta de força de vontade ou de vergonha na cara”, uma vez 
que os membros de AA levam para essas instituições, muitas delas formadoras, como as escolas, a noção de alcoolismo como doença incurável e progressiva.

Nos programas na mídia, os membros de AA são convidados a expor sobre o alcoolismo, tendo sua imagem sombreada em virtude do princípio do anonimato.

Logo, nos solidarizamos com as abordagens dos grupos de mútua ajuda e vemos neles algumas perspectivas de empoderamento, com os limites já mencionados. Nossa convicção a respeito da importância desses grupos repousa no fato de que, durante os três anos de pesquisa em que frequentamos as reuniões do AA, o que vimos de mais recorrente foram homens e mulheres que conseguiram (apesar das inúmeras contradições e ambiguidades inerentes ao processo de recuperação proposto por essa irmandade) obter esperança de vida, reconstruir laços desfeitos pelo alcoolismo e estabelecer pequenas metas para suas vidas, ainda que, segundo um dos principais lemas das irmandades anônimas, tais metas sejam estabelecidas apenas "só por hoje".

\section{Referências}

CENTRO BRASILEIRO DE INFORMAÇÕES SOBRE DROGAS PSICOTRÓPICAS (CEBRID). I Levantamento Domiciliar sobre o Uso de Drogas Psicotrópicas no Brasil. São Paulo: Universidade Federal de São Paulo, Departamento de Psicobiologia, 2001.

DAMATTA, R. Carnavais, Malandros e Heróis. Rio de Janeiro: Zahar, 1983.

JUNTA NACIONAL DE ALCOÓliCOS ANÔNIMOS NO BRASIL (JUNAAB). Doze Conceitos para Serviços Mundiais. São Paulo: Junta Nacional de Alcoólicos Anônimos, 1999.

JUNTA NACIONAL DE ALCOÓLICOS ANÔNIMOS NO BRASIL (JUNAAB). Os Doze Passos e as Doze Tradições. São Paulo: Junta Nacional de Alcoólicos Anônimos, 2004.

MASCAREnHAS, E. Alcoolismo, Drogas e Grupos Anônimos de Mútua-Ajuda. São Paulo: Siciliano, 1990.

MOTA, L. A. A Dádiva da Sobriedade: a ajuda mútua nos grupos de alcoólicos anônimos. São Paulo: Paulus, 2004.

REIS, T. R. Fazer em Grupo o que Eu Não Posso Fazer Sozinho: indivíduo, grupo e identidade social em Alcoólicos Anônimos, 2007. Tese de Doutorado, Rio de Janeiro: Escola de Serviço Social, Universidade Federal do Rio de Janeiro.

VASCONCELOS, E. M. O Poder que Brota da Dor e da Opressão: empowerment, sua história, teorias e estratégias. São Paulo: Paulus, 2003. 
VASCONCELOS, E. M. Dispositivos Associativos e de Empoderamento de Usuários, Familiares e Trabalhadores em Saúde Mental no Brasil. Rio de Janeiro: Projeto Transversões, 2007. (Texto de discussão interna)

VELHO, G. Individualismo e Cultura: notas para uma antropologia da sociedade contemporânea. 7. ed. Rio de Janeiro: Zahar, 2004.

WEINGARTEN, R. O Movimento de Usuários em Saúde Mental nos Estados Unidos: história, processos de ajuda e suporte mútuos e militância. Rio de Janeiro: Projeto Transversões, Instituto Franco Basaglia, 2001.

\section{Sites de grupos de ajuda mútua}

Alcoólicos Anônimos <www.aa.org.br>

Narcóticos Anônimos <www.na.org.br>

Jogadores Anônimos <www.jogadoresanonimos.org>

Neuróticos Anônimos <www.neuroticosanonimos.org.br>

Dependentes de Amor e Sexo Anônimos<www.slaa.org.br>

Comedores Compulsivos Anônimos <http://brgeocities.com/ccabrasil>

Mulheres que Amam Demais Anônimas <www.grupomada.com.br>

Devedores Anônimos <www.devedoresanonimos.rj.cjb.net>

Fumantes Anônimos <www.fumantesanonimos.org>

Codependentes Anônimos <http//codependentes.freeyellow.com>

$<w w w . c u i d a r d o s e r . c o m . b r>$ 


\section{Anexo}

\section{Os Doze Passos de AA}

1o Passo: 'Admitimos que éramos impotentes perante o álcool - que tínhamos perdido o domínio sobre nossas vidas';

2 Passo: 'Viemos a acreditar que um Poder Superior a nós mesmos poderia devolver-nos à sanidade';

3 o Passo: 'Decidimos entregar nossa vontade e nossa vida aos cuidados de Deus, na forma em que O concebíamos';

4 Passo:'Fizemos minucioso e destemido inventário moral de nós mesmos'; 5 o passo:'Admitimos perante Deus, perante nós mesmos e perante outro ser humano a natureza exata de nossas falhas';

6 passo:'Prontificamo-nos inteiramente a deixar que Deus removesse todos esses defeitos de caráter';

$7^{\circ}$ passo: 'Humildemente rogamos a Ele que nos livrasse de nossas imperfeições';

8o Passo:'Fizemos uma relação de todas as pessoas que tínhamos prejudicado e nos dispusemos a reparar os danos a elas causados';

9o Passo: 'Fizemos reparações diretas dos danos causados a tais pessoas, sempre que possível, salvo quando fazê-las significasse prejudicá-las ou a outrem';

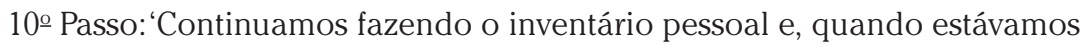
errados, nós o admitíamos prontamente';

11ํ Passo: 'Procuramos através da prece e da meditação, melhorar nosso contato consciente com Deus, na forma em que o concebíamos, rogando apenas o conhecimento de Sua vontade em relação a nós e forças para realizar essa vontade';

12을 Passo:'Tendo experimentado um despertar espiritual, graças a estes passos, procuramos transmitir esta mensagem aos alcoólicos e praticar estes princípios em todas as nossas atividades'. (Junaab, 2004: 3-7) 


\section{0}

\section{Reflexões sobre o Campo da Psicologia \\ e o Uso Abusivo de Drogas}

Carolina Fernandes Pombo-de-Barros

Verônica Silva Fernandez

A proposta deste estudo é compartilhar algumas reflexões empreendidas no decorrer de nossa formação e em nossas experiências profissionais no campo da saúde pública, fruto de leituras, estudos e práticas. Pretendemos, por isso, que este seja um convite à reflexão sobre o olhar e a prática do psicólogo no âmbito do tratamento/assistência de usuários de drogas.

No texto, o problema de uso e abuso de drogas é caracterizado como uma questão de saúde pública. Em seguida, são explorados os conceitos de inter e transdisciplinaridade. A transdisciplinaridade é vista como um paradigma científico que emerge das críticas à separação dos campos de conhecimento e que alimenta nossas reflexões. A interdisciplinaridade é proposta como eixo integrador da psicologia na saúde pública e como norteador para a atuação do psicólogo no Sistema Único de Saúde (SUS). Para a discussão da realidade das mudanças processadas atualmente no campo da psicologia, assinalamos algumas considerações do relatório final do I Fórum de Psicologia e Saúde Pública (CFP, 2006) e levantamos os desafios para a formação e atuação dos psicólogos nos serviços de saúde para usuários de drogas. 


\section{A Drogadicção como Problema de Saúde Pública}

Para entender a questão do uso e abuso de drogas como um problema de saúde pública é necessário compreender a utilização dessas substâncias ao longo da própria história da humanidade. O uso de substâncias que alteram a percepção habitual da realidade e transformam estados psíquicos caminha, paralelamente, à trajetória do homem, desde épocas passadas até o período contemporâneo.

As substâncias psicoativas, psicotrópicas ou, no uso popular, as drogas, são definidas como aquelas substâncias que alteram funções de organismos vivos, produzindo mudanças fisiológicas ou de comportamento. Foram e são largamente utilizadas por sociedades antigas e atuais, em rituais religiosos, fenômenos socioculturais e procedimentos terapêuticos com reconhecimento científico ou não. Do ponto de vista político e econômico, em diferentes períodos históricos, governos lançaram mão de incentivos à produção e à comercialização de alguns tipos de drogas e à proibição do uso e comercialização de outras. Em prol do crescimento e desenvolvimento econômico e pela disputa da hegemonia de mercado no cenário internacional, as políticas reguladoras ou proibicionistas do uso de determinadas substâncias têm papel marcante na história de diversos países. Desde remédios de antigos boticários até alucinógenos usados em rituais religiosos, passando pela fabricação e utilização do álcool, como o vinho e a aguardente, em celebrações sociais, as drogas ainda estão intensamente presentes nas sociedades humanas (Venâncio \& Carneiro, 2005).

Atualmente, o abuso de determinadas substâncias pelo homem tem alcançado proporções destrutivas e desagregadoras. Políticas de controle às drogas, proibições e a regulamentação da sua utilização vêm sendo planejadas e implantadas diante dos números alarmantes divulgados por pesquisas nacionais ${ }^{1}$ e internacionais. Esses números alarmantes dizem respeito não só a um quantitativo maior de sujeitos usuários, mas também ao reconhecimento das consequências diretas (comorbidades) e indiretas (violência, tráfico, acidentes de trânsito) do consumo exacerbado.

Valores culturais, significados pessoais, acesso, oferta, predisposição genética, contextualização social e familiar, história de vida e políticas públicas são

\footnotetext{
1 Em 2007, a Secretaria Nacional Antidrogas (Senad) publicou um estudo pioneiro sobre o consumo de bebidas alcoólicas no Brasil. A pesquisa foi realizada pela Universidade Federal de São Paulo (Unifesp), e é o primeiro estudo que caracteriza o padrão brasileiro de consumo da substância mais utilizada no mundo, conforme dados da Organização Mundial da Saúde (OMS).
} 
alguns fatores que podem influenciar a formação ou a mudança de um hábito ou comportamento, como os que configuram o vício ou compulsão. A identificação de diversas implicações sociais e individuais do abuso de drogas aponta para a caracterização deste como um problema de saúde pública. Esse reconhecimento demanda intervenções que ultrapassem juízos morais, exigindo um olhar aberto às múltiplas dimensões e não somente à ótica biomédica. Assim, destacamos que as intervenções sobre a questão das drogas são do campo da saúde pública, porque requerem a integração, promovida por esse campo, de diferentes áreas do conhecimento, como a medicina, a psicologia, a educação, a epidemiologia entre outras.

A evolução do conceito de uso nocivo e dependência e a caracterização da drogadicção como doença por organismos mundiais - como no caso do alcoolismo, por exemplo, pela OMS - constituem dispositivos que auxiliam na reflexão e no enfrentamento da questão. A ideia de reduzir danos, assumida por alguns governos como orientação política, tem norteado serviços e práticas de saúde voltados às toxicomanias e suas comorbidades e não coloca a abstinência como o único objetivo a ser alcançado. A redução de danos considera as singularidades e as diferentes possibilidades e escolhas relacionadas ao tratamento. Preconiza o acolhimento, sem julgamento prévio, buscando analisar cada caso na sua singularidade, estimulando a participação e o engajamento de cada usuário na formação de estratégias de tratamento, para melhorar a qualidade de vida e evitar outras doenças. Outros métodos não são excluídos, o que aumenta a liberdade e a corresponsabilidade do usuário (Brasil/MS, 2004).

\section{Transdisciplinaridade e Interdisciplinaridade na Psicologia}

Por se tratar de um fenômeno complexo, identificado como objeto de intervenção de diversas áreas do conhecimento, a drogadicção deixa de ser objeto privilegiado da medicina (epidemiológica e psiquiátrica) e do Direito - áreas nas quais tradicionalmente é tratada - constituindo-se em tema de interesse para estudos do campo da psicologia e das ciências sociais e humanas em saúde. As pesquisas na área da psicologia têm tido diferentes formatos e objetivos. Há pesquisas clínicas de abordagem psicanalítica ou comportamental, pesquisas de representações sociais e estudos sobre a eficácia de práticas educativas e preventivas. Como se trata de uma disciplina com várias orientações teóricas, são vários também os olhares e as práticas direcionados aos sujeitos usuários de 
drogas. Em alguns casos, as teorias e os conceitos podem ser articulados e, além disso, podem dialogar com outras disciplinas; em outros casos, essa possibilidade fica limitada por enfoques demasiadamente 'psíquicos' ou individualistas.

Tendo em vista as implicações sociais, psicológicas, econômicas e políticas já citadas, parece-nos interessante uma compreensão global, promovida pelo encontro de pesquisas de campos distintos, para o entendimento das múltiplas dimensões e determinações do fenômeno. Esse movimento de integração de teorias e conceitos de diferentes disciplinas aponta para a transdisciplinaridade, um paradigma renovado com as críticas à 'separabilidade' dos saberes e práticas, imposta pelo positivismo. Em contrapartida, no âmbito das práticas profissionais, a interdisciplinaridade aparece como modelo facilitador para o trabalho com questões complexas, como a drogadicção. Assim, a compreensão e a articulação desses conceitos se fazem necessárias para avançarmos em nossas reflexões.

O tratamento de determinados assuntos a partir da ótica de um único campo de conhecimento específico tem origem histórica. Souza (1998), ao discutir a racionalidade científica moderna, aponta a divisão do saber como um traço distintivo inerente a ela. A partir do século XIX, com o positivismo e o cientificismo, essa concepção fragmentada do saber tornou-se hegemônica. Já no século XX, mais pontualmente, a partir dos anos 60, puderam-se notar, em algumas instituições de ensino e pesquisa, movimentos para reverter o modelo de formação, defendendo-se a reintegração das disciplinas segundo diferentes perspectivas: a multidisciplinaridade, a interdisciplinaridade e a transdisciplinaridade (Souza, 1998).

Essas terminologias, porém, possuem caracterizações e significados distintos por parte de diversos autores. Conforme Japiassu (1976), as duas primeiras, distinguem-se, entre si, pelo fato de entender-se por multidisciplinar a justaposição de saberes específicos de duas ou mais disciplinas, não havendo, contudo, integração conceitual, muito menos metodológica. O caráter multidisciplinar tem-se mostrado, atualmente, hegemônico, porém, na sua prática, é utilizado, indevidamente, o termo 'interdisciplinar'.

Como interdisciplinaridade, pode-se afirmar que as diferentes definições encontradas indicam um sentido, sendo esta entendida como "a síntese de duas ou mais disciplinas integrando e convergindo os diversos esquemas conceituais e de análise das áreas do saber" (Souza, 1998: 24). Para essa integração, porém, faz-se necessária a aproximação prévia entre as disciplinas, ou seja, a conjugação de pontos em comum. 
O termo transdisciplinaridade teve sua origem nas obras de Piaget, que o definiu como uma etapa superior, "onde as interrelações não atingiriam apenas algumas disciplinas, mas o sistema da ciência em sua totalidade" (Souza, 1998: 25).

No âmbito das ciências humanas e sociais, as críticas de Edgar Morin (1999) produziram a ampliação do olhar sobre o homem e sua relação com o ambiente. O autor argumenta que a antropologia, em seus primórdios, desenvolveu-se com base em uma premissa antinaturalista, caracterizando o paradigma natureza versus cultura. Essa cisão orientou o desenvolvimento das ciências e resultou numa visão de mundo segmentada em três estratos: humanidades versus biologia versus física e química (Morin, 1971). Alternativamente, esse autor propôs o olhar da complexidade sobre o objeto científico. O olhar da complexidade é basicamente a constatação da constituição multidimensional dos homens e seus ambientes.

Novas teorias atentas a essas críticas, tanto no campo das ciências naturais quanto no das ciências humanas, possibilitaram uma visão sistêmica e provocaram a aproximação entre seus conceitos, contrastando com a premissa básica de separabilidade do positivismo e corroborando a proposta da transdisciplinaridade e das práticas pautadas na interdisciplinaridade.

O desenvolvimento das ciências cognitivas e sua interface com ramos da psicologia serviram para levantar críticas contundentes à visão estruturalista que isola a subjetividade no 'interior' do indivíduo. Cresce, então, a noção de que só é possível compreender a autonomia de um ser vivo situando-o em seu contexto de dependências múltiplas com seu meio ambiente (Morin, 1999). Ao mesmo tempo, a renovação do campo da saúde pública, com a ampliação dos conceitos de saúde e doença, fomenta o debate sobre a insuficiência do modelo preventivista para ações de saúde que contemplem os determinantes sociais. Assim, a transdisciplinaridade aparece como proposta de renovação científica e epistemológica, e a interdisciplinaridade passa a ser, gradualmente, inserida no planejamento de ações de saúde e em seus respectivos cursos de formação.

\section{Saúde Pública e Psicologia: 0 desafio da questão do abuso de drogas}

Nosso objetivo, a partir de agora, é abordar alguns dos desafios para a formação e atuação de psicólogos na atenção à clientela usuária de drogas. 
O campo teórico e prático da psicologia é amplo e diversificado. Há teorias e instrumentos de atuação que divergem e outros que se complementam, debruçando-se, às vezes, sobre os mesmos problemas por meio de enfoques diferentes. Apesar dessa heterogeneidade, este é um campo científico relativamente autônomo, nos termos de Bourdieu (2007), que está em constante reorganização em função das influências de outros campos de conhecimento e das pressões sociais. Uma fonte dessas influências é o campo da saúde pública no Brasil, que tem interseções importantes com a psicologia, em uma relação retroalimentar, que contribui para ambos. Passemos a analisar como o tema do abuso de drogas desponta como intercessor entre esses campos.

No ano de 2006, o Conselho Federal de Psicologia (CFP) promoveu o primeiro fórum com o objetivo de discutir e de encaminhar propostas sobre a atuação dos psicólogos na saúde pública, abarcando desde a dimensão política até a clínica. Esse evento foi resultado do reconhecimento da crescente participação do profissional de psicologia nos serviços de saúde e na construção do SUS. Como consta do relatório final do fórum, a inserção desse profissional ocorreu, inicialmente, na atenção à saúde mental, mas ampliou-se para a capacitação, gestão de pessoal e direção de serviços, tanto no primeiro nível de atenção à saúde quanto em níveis de maior complexidade. Sobre o tema álcool e outras drogas, o fórum emitiu duas decisões que se resumem basicamente em: fiscalizar a atuação dos psicólogos que trabalham com essa clientela, quanto à proteção dos direitos humanos, e difundir as ferramentas teóricas e técnicas psicológicas que vão ao encontro da redução de danos, a fim de contribuir para a promoção dessa lógica de atendimento.

No evento, os participantes demonstraram preocupação com a construção de políticas públicas de saúde que garantam os princípios orientadores para o campo presentes na Constituição Federal. Algumas resoluções do relatório expressam o compromisso em torno da formação de profissionais que se afinem aos ideais do SUS, que possam "prestar uma atenção integral, humana, ética e tecnicamente qualificada". Sobre o campo da saúde pública, especificamente, o relatório defende "a implementação de táticas de intervenção que considerem a multideterminação do processo saúde/doença e valorizem estratégias de promoção da integração da equipe" (CFP, 2006: 12). O sistema de conselhos também se comprometeu a promover debates interdisciplinares e a incentivar a atuação do psicólogo em equipes inter e multiprofissionais. Tendo em vista as proposições e compromissos tratados nesse encontro, fica claro que, cada vez mais, o tema da interdisciplinaridade é incorporado por essa categoria 
profissional. A integração, cada vez maior, no campo da saúde pública, também tem contribuído para isso.

Sobre a formação dos psicólogos, o relatório está em consonância com os ideais de formação permanente em saúde e procura estimular a integração de instituições políticas, educacionais e de saúde. Essa estratégia vincula-se à proposta de

desenvolver profissionais críticos, capazes de aprender a aprender, de trabalhar em equipe, de levar em conta a realidade social para prestar atenção humana e de qualidade, a fim de melhorar permanentemente a qualidade do cuidado à saúde e poder constituir práticas profissionais críticas, éticas e humanísticas. (CFP, 2006: 15)

A questão do uso abusivo de drogas aparece como um dos pontos de interseção entre a saúde pública e a psicologia, impulsionando algumas reflexões para os psicólogos como profissionais de saúde. Consideramos que esse é mais do que um problema individual que necessita de intervenções clínicas, é um problema que abarca dimensões políticas, sociais e culturais, convergente ao movimento de ampliação do campo da psicologia. Contudo, reconhecemos também os desafios que ele propõe e que vão ao encontro exatamente das proposições já mencionadas. De que maneira, portanto, esses desafios podem ser enfrentados na formação e na prática psicológica?

O reconhecimento dessa temática no campo da psicologia já expressa uma resposta às críticas sobre a atuação 'privatista', ${ }^{2}$ baseada em uma cultura psicanalítica (Dimenstein, 2000), que vem sendo levantada, desde a década de 1980 por diversos autores (Coimbra, 2002; Vasconcelos, 2004; Silva, 1992; Costa, 1989). Todas essas críticas se defrontam com o núcleo cristalizado do campo, formado pela figura do psicólogo clínico de consultório particular. A discussão do problema do uso abusivo de drogas na perspectiva da saúde pública desafia a ideia de 'sujeito psicológico' característica desse tipo de intervenção. O sujeito psicológico é o paciente idealizado pelos psicólogos que se orientam por uma visão individualista da subjetividade (Dimenstein, 2001). Algumas abordagens são marcadas fortemente por essa idealização, como a teoria psicanalítica de enfoque estruturalista.

2 O termo 'privatista' é inspirado no conceito de modelo clínico liberal privatista de Dimenstein (2000) e diz respeito a uma ideologia individualista, que valoriza interesses privados em detrimento dos interesses públicos e que influencia a prática dos psicólogos clínicos em muitos casos. 
Ainda que se tenha configurado um campo relativamente autônomo, a psicanálise repercutiu de forma dominante sobre a formação e a prática da psicologia no Brasil. Segundo Dimenstein (2001), a formação dos psicólogos baseia-se, em grande parte, na cultura psicanalítica, uma vez que os profissionais são formados para atender aos sujeitos psicológicos, caracterizados pelo autocultivo e ênfase na interioridade e imersos na cultura do narcisismo (Lasch, 1983). Essa dinâmica reforça uma postura negligente de alguns psicólogos quanto às vicissitudes políticas e sociais e produz a naturalização da subjetividade individualista. Essa visão de subjetividade está articulada à ideia de um indivíduo independente, que dá ao saber psi o papel de especialista, com um objeto específico e restrito de sua intervenção: o indivíduo.

Porém, a presença da teoria psicanalítica na formação dos profissionais que tentam atender às demandas colocadas pelo uso de drogas, dentro de serviços de orientação interdisciplinar, produz impasses, mas também realimenta o campo. Este é o movimento esperado, se o analisarmos, com Bourdieu (2007), como o encontro de forças sociais sobre um campo científico relativamente organizado e coeso. Se o considerarmos assim, saberemos que as pressões sociais precisam se tornar pressões lógicas, transformadas em argumentos que dialoguem com a ciência em pauta. ${ }^{3}$ Há regras ou hábitos experimentados e reproduzidos pelos agentes que constituem o campo da psicanálise, o campo da psicologia, e que agora, mais do que nunca, se inserem no campo da saúde pública. Essas experiências se confrontam e enriquecem as intervenções quando se abrem para o diálogo, contribuindo também para outras áreas, para atendimentos mais humanizados que incorporem questões subjetivas.

As representações desses agentes que, a princípio, procuram utilizar a realidade para reforçar sua visão de mundo têm sido desafiadas e, em alguns casos, anuladas pela inserção social nos serviços pautados pela lógica da redução de danos e por outras propostas de tratamento que pretendem aumentar a autonomia e o engajamento dos sujeitos. Assim, as mesmas conhecidas técnicas (oficinas terapêuticas, psicoterapias de grupo, psicoterapias individuais, práticas preventivas etc.) têm sido reavaliadas e reenquadradas nessa realidade. A força política do movimento pela reforma sanitária e do movimento pela reforma psiquiátrica tem, claramente, um papel nessas mudanças, sobretudo porque expressam representações diferentes a respeito da relação

\footnotetext{
3 Não pretendemos aqui entrar na discussão sobre a cientificidade ou sobre o que se considera ciência stricto sensu, apenas levantar considerações sobre o campo da psicanálise e da psicologia.
} 
entre subjetividade e realidade social e promovem novas visões de mundo, especialmente do mundo da saúde/doença. Para esses movimentos, a saúde é um objeto complexo de dimensões biológicas, ecológicas, econômicas e psicossociais, que são articuladas. Essa articulação produz uma face política que procura promover a autonomia dos indivíduos e a participação na construção de políticas públicas.

Destacamos, então, a ineficiência da transposição do modelo privatista para a esfera pública, visto que, como ocorre ainda em alguns serviços ambulatoriais de psicologia, o sujeito é convocado a pensar seu sofrimento apenas como intrapsíquico (Dimenstein, 2000; Costa, 1989; Barros, 2002). Com essa dinâmica, visualizamos dois caminhos que a clientela desses serviços pode percorrer. $\mathrm{O}$ primeiro constitui-se em um processo de subjetivação produzido pela relação terapêutica isolada das contribuições de outros campos, o que reforça uma dependência emocional do paciente. Assim, ao invés de se promover a autonomia do sujeito, pode-se promover uma identidade vitimizada (Barros, 2002) ou, por outro lado, culpabilizada pelo vício. No outro caminho, encontra-se a grande maioria, que permanece poucos meses em atendimento psicoterapêutico e busca na medicação excessiva ou em outros dispositivos, como os religiosos, quando possível, uma forma de lidar com seu sofrimento e de escapar do vício.

\section{Conclusão}

A primeira contribuição do paradigma da transdisciplinaridade para as reflexões deste texto é a consideração da complexidade da subjetividade e de uma postura epistemológica que, ao ser adotada pelos psicólogos, pode favorecer sua integração em equipes e pesquisas interdisciplinares. A segunda contribuição está no embasamento para propostas interdisciplinares de atendimento a usuários de álcool e outras drogas, que levem em conta as múltiplas dimensões já abordadas. Assim, partindo dessa discussão, podemos afirmar que no âmbito da saúde pública, uma visão restrita do sujeito, pautada por uma lógica privatista, que utiliza o indivíduo como objeto legitimador dessa ciência, não é mais adequada aos psicólogos, uma vez que sua intervenção extrapolou os consultórios particulares. Essa representação do sujeito não é mais necessária para a autonomização do campo, mas, pelo contrário, deve ser desconstruída e substituída por uma visão complexa que favoreça a articulação com outras disciplinas. 
A constatação dos impasses, as demandas do encontro da psicologia com a saúde pública e as especificidades do problema da drogadicção devem subsidiar a formação teórica e as representações dos agentes desse campo. Sendo assim, pensamos que as graduações e pós-graduações em psicologia precisam manter-se atualizadas e articuladas aos movimentos das demais instituições, como o sistema de conselhos profissionais e os fóruns de discussão, além de deixarem-se permear pela produção científica recente. Consideramos ainda que diferentes formatos clínicos, advindos das diferentes abordagens teóricas da psicologia, podem convergir para o atendimento adequado dos sujeitos usuários de drogas, mas precisam ser orientados pela visão ampliada, complexa e contextualizada da subjetividade e das práticas terapêuticas.

\section{Referências}

BARROS, R. B. Clínica e social:polaridades que se opõem/complementam ou falsa dicotomia? In: RAUTER, C.; PASSOS, E. \& BARROS, R. B. (Orgs.). Clínica e Política: subjetividade e violação dos direitos humanos. Rio de Janeiro: Equipe Clínico-Grupal, Grupo Tortura Nunca Mais - RJ, Instituto Franco Baságlia, Editora Te Cora, 2002.

BOURDIEU, P. Os Usos Sociais da Ciência. Por uma Sociologia Clínica do Campo Científico. São Paulo: Unesp, 2007.

BRASIL. Ministério da Saúde. Secretaria de Atenção à Saúde. SVS/CN-DST/AIDS. A Política do Ministério da Saúde para Atenção Integral a Usuários de Álcool e outras Drogas. 2. ed. rev. ampl. Brasília: Ministério da Saúde, 2004.

COIMBRA, C. M. B.Violência do Estado e violência "doméstica": o que têm em comum? In: RAUTER, C.; PASSOS, E. \& BARROS, R. B. de (Orgs.). Clínica e Política: subjetividade e violação dos direitos humanos. Rio de Janeiro: Equipe Clínico-Grupal, Grupo Tortura Nunca Mais - RJ, Instituto Franco Baságlia, Editora TeCorá, 2002.

CONSELHO FEDERAL DE PSICOLOGIA (CFP). Contribuições Técnicas e Políticas para Avançar o SUS. I Fórum Nacional de Psicologia e Saúde Pública. Brasília, 2006. (Relatório Final)

COSTA, J. F. Psicanálise e Contexto Cultural. Rio de Janeiro: Campus, 1989.

DIMENSTEIN, M. A cultura profissional do psicólogo e o ideário individualista:implicações para a prática no campo da assistência pública à saúde. Estudos de Psicologia, 5(I): 95-121, 2000. 
DIMENSTEIN, M. O psicólogo e o compromisso social no contexto da saúde coletiva. Psicologia em Estudo, 6(2): 57-63, 2001.

JAPIASSU, H.Interdisciplinaridade e Patologia do Saber. Rio de Janeiro: Imago, 1976.

LASCH. C. A Cultura do Narcisismo. Rio de Janeiro: Imago, 1983.

MORIN, E. O Enigma do Homem - para pensar uma nova antropologia. Rio de Janeiro: Zahar, 1971.

MORIN, E. Por uma reforma do pensamento. In: PENA-VEGA, A. \& NASCIMENTO, E. P. (Orgs.). Pensar Complexo: Edgar Morin e a crise da modernidade. Rio de Janeiro: Garamond, 1999.

SILVA, R. C. A formação em psicologia para o trabalho na saúde pública. In: CAMPOS, F. C. B. (Org.). Psicologia e Saúde - repensando práticas. São Paulo: Hucitec, 1992.

SOUZA, C. M. F. A Construção do Conhecimento Epidemiológico-Nutricional no Brasil, 1998. Dissertação de Mestrado em Saúde Coletiva, Salvador: Instituto de Saúde Coletiva, Universidade Federal da Bahia.

VASCONCELOS, E. Mundos paralelos, até quando? Os psicólogos e o campo da saúde mental pública no Brasil nas duas últimas décadas. Mnemosine, 1: 108-134, 2004.

VENÂNCIO, R. P. \& CARNEIRO, H. Álcool e Drogas na História do Brasil. São Paulo, Belo Horizonte: Alameda, Editora PUC Minas, 2005. 


\title{
Drogas de Desempenho: \\ a Ritalina e o transtorno do déficit de atenção/hiperatividade (TDAH)
}

\author{
Luciana Caliman
}

\section{O TDAH na "Década do Cérebro"}

Em um artigo de 1999, publicado pela Heritage Foundation, Mary Eberstadt (1999) descrevia o "cenário TDAH" na década de 1990. De acordo com a autora, desde o final da década de 1980 e durante os anos 90, o mundo presenciou uma explosão publicitária sobre o transtorno do déficit de atenção/hiperatividade (TDAH) e a Ritalina, o medicamento mais conhecido e utilizado no tratamento do transtorno naquela época. Livros sobre o assunto, como Tendência à Distração, de Hallowell e Ratey, publicado em 1994, alcançaram a categoria de bestsellers. Entre livros e artigos, a lista crescia, e o adulto TDAH tornava-se parte do público interessado. O TDAH, até então considerado um diagnóstico infantil, passava a ser visto como uma desordem do desenvolvimento que continuava na vida adulta, constituindo, portanto, um quadro crônico incurável.

Em 1994, foi publicado o quarto volume do Diagnostic and Statistical Manual of Mental Disorders [Manual Estatístico e Diagnóstico de Transtornos Mentais] (APA, 1994), e o TDAH foi definitivamente reconhecido como tal. Especialmente nos Estados Unidos, a compreensão e o tratamento do TDAH tornaram-se necessidades vinculadas à gestão social e econômica da nação. Em 2004, o TDAH foi oficialmente reconhecido, por meio da resolução n. 370, como um dos problemas 
mais graves e importantes da saúde pública americana. De acordo com as estimativas publicadas nessa resolução, o TDAH abrangia de 3 a 7\% das crianças e adolescentes americanos em idade escolar (dois milhões) e $4 \%$ dos adultos (oito milhões). Em virtude da assinatura dessa resolução, o dia 7 de setembro foi proclamado o "Dia da Consciência Nacional sobre o TDAH", marcando, assim, a entrada do transtorno para as datas oficiais do país.

As estatísticas americanas sobre o TDAH são também econômicas e baseiam-se na estimativa dos custos médicos e sociais do transtorno. Ao fazerem uma revisão bibliográfica sobre o assunto, Matza, Paramone e Prasada (2005) constataram que um número crescente de pesquisas tem se ocupado da análise das 'possíveis' perdas econômicas aparentemente relacionadas ao TDAH. Além dos gastos com seguro saúde, medicamentos, consultas e tratamentos, as autoras analisam o impacto econômico da criminalidade entre indivíduos com TDAH, os custos vinculados ao desemprego ou à constante mudança de empregos, e as despesas relacionadas aos frequentes acidentes automobilísticos envolvendo esses indivíduos. Embora baseadas em análises que são, sobretudo, especulativas, essas pesquisas enfatizam que o TDAH deve ser visto e tratado como um fator de risco, como uma ameaça para os ideais de segurança e de produtividade individual e social do país.

Foi também durante as décadas de 1980 e 1990 que a interpretação neurobiológica do transtorno tornou-se amplamente aceita. Não é por acaso que, analisando o cenário científico americano, Lakoff (2000) descreve a década de 1990 como a "década do cérebro", o auge dos estudos neurológicos sobre o déficit de atenção, financeiramente marcado por um investimento maciço do Instituto Nacional de Saúde Mental (NIMH). Para Barkley (1997a, 1997b, 1998), a autoridade mais conhecida no debate internacional sobre o TDAH, o transtorno era uma disfunção neuropsiquiátrica que afetava o desenvolvimento das funções executivas cerebrais, da capacidade de autocontrole, de planejamento e de execução de ações orientadas por objetivos futuros.

Mais do que nunca, os estudos sobre a desordem da atenção e do controle do comportamento e a pesquisa cerebral estavam conectados. A existência do transtorno e a validade do diagnóstico dependiam da descoberta de suas bases biológicas e cerebrais e dos cálculos de seu potencial de risco. No discurso da legitimidade do transtorno, além da comprovação dos males causados pelo TDAH e de seu potencial de risco, e, em certo sentido, mais importante do que eles, encontra-se o argumento sobre suas causas físicas. Trata-se não apenas de demonstrar que o transtorno 'causa' danos ao sujeito, mas que ele, o transtorno, 
é 'causado' por aspectos biológicos, genéticos e cerebrais. Tais suscetibilidades biológicas não são os únicos fatores que influenciam o desenvolvimento da patologia, mas são, sem dúvida, os mais importantes.

Os dados que fundamentam o discurso da legitimação médica e biológica do TDAH vêm das pesquisas neurológicas e das funções cerebrais, dos estudos feitos com as tecnologias de imagem cerebral e da pesquisa molecular e genética. Por meio deles, o discurso neuropsiquiátrico dominante indica ser possível demonstrar que o transtorno é real porque, finalmente, seus fatores biológicos foram descobertos e, parte deles, tornou-se passível de visualização, observação, universalização e comunicação científica. O argumento pode ser assim resumido: o diagnóstico do TDAH é real porque, em certa medida, é visível e biológico e descreve uma condição maligna.

Porém, apesar de ser aclamado como um dos diagnósticos psiquiátricos mais estudados no campo neuropsiquiátrico, o diagnóstico do TDAH também é considerado um dos mais controversos de nossos tempos. O diagnóstico tem sido descrito como uma 'polêmica' de interesse internacional, que desconhece barreiras culturais e sociais. Os paradoxos em torno do transtorno invadem a mídia mundial, que tem divulgado o TDAH como diagnosis du jour, boutique disorder, psychofad, e a Ritalina como a 'pílula da obediência'. Além disso, suas controvérsias são discutidas pelos profissionais mais importantes do campo da neuroética e das ciências humanas e sociais.

Nos tópicos seguintes, abordaremos alguns dos pontos controversos em torno do diagnóstico do TDAH, com o objetivo de estimular o fortalecimento do debate sobre o transtorno nas áreas psicológica, médica e educacional. Não colocamos em questão a realidade, a existência ou a legitimidade do diagnóstico do TDAH. Ao analisarmos alguns de seus pontos críticos, buscamos contribuir para que, no âmbito das práticas e das políticas de saúde, o TDAH possa ser melhor analisado e seus desafios devidamente considerados.

\section{A 'Polêmica TDAH':}

\section{entre as funções e as disfunções da atenção e sua otimização}

Em 2005, em nove países da União Europeia, várias conferências intituladas Meetings of Minds (2005) foram organizadas com o objetivo de debater questões relevantes sobre a pesquisa cerebral. Representantes das instâncias 
públicas, legais, científicas, acadêmicas, empresariais e do público em geral reuniram-se com o intuito de formular propostas para a pesquisa cerebral farmacológica, médica, neurológica e ética.

A conferência alemã (Europäische Bürgerkonferenz zur Hirnforschung) teve lugar na cidade de Dresden, nos dias 25, 26 e 27 de novembro de 2005. Dentre todos os temas debatidos nessa conferência, as polêmicas em torno do TDAH dominaram a cena. Um dos conferencistas chegou a comentar que era preciso lembrar que a pesquisa cerebral não se resumia à pesquisa sobre o TDAH. No material de propaganda da conferência, a única patologia citada foi o TDAH. Mas, afinal, quais são as questões que alimentam a polêmica em torno desse transtorno?

Muitos são os aspectos que fazem com que o diagnóstico do TDAH seja descrito como uma 'polêmica internacional'. O aumento do número de casos identificados em crianças, adolescentes e adultos, a disseminação das prescrições de estimulantes e a proliferação dos processos legais que, com base na evidência do diagnóstico, pleiteavam o direito à educação especial e privilégios no ambiente de trabalho, têm contribuído para a disseminação de um clima de suspeita.

Assim como no discurso da legitimação do TDAH, são também números e estatísticas que alimentam suas controvérsias. Para citar apenas algumas cifras alarmantes a respeito da Ritalina, a revista The New York Times, de janeiro de 1999, informava que a produção do medicamento havia aumentado em torno de 700\%, desde o início da década, por causa do número de crianças americanas sob medicação. Em 1999, os Estados Unidos fizeram uso de 85\% da produção mundial de metilfenidato para propósitos médicos, e é preciso lembrar que esse medicamento não é comumente usado no tratamento de outras patologias (com exceção da narcolepsia). O número de consumidores crescia e era especialmente formado pelo público infantil e adolescente.

Um dos dados mais alarmantes foi divulgado por Degrandpre (2000), que, ao comentar a análise de alguns especialistas, relatou que $7 \%$ da população mundial já havia sido diagnosticada como portadora do transtorno. Em uma análise mais recente, Singh (2005) revelou que estimativas de 2001 indicavam que aproximadamente $3 \%$ das crianças americanas em idade escolar estavam tomando algum tipo de medicamento estimulante contra o TDAH. Em relação aos processos legais que, baseados no diagnóstico do TDAH, solicitavam o direito à educação especial, as estatísticas de 2000, analisadas por Gordon e Keiser (1998), revelavam que nos últimos cinco anos esse número, surpreendentemente, havia dobrado e começava a preocupar as organizações públicas. 
Na Alemanha, em 2004, um volume inteiro da revista Gehirn \& Geist [Cérebro \& Mente], intitulado "Generation ADHS" ["Geração TDAH"], foi especialmente dedicado à discussão do transtorno. De acordo com Könneker (2004), os números alemães indicavam que cerca de 500 mil crianças e adolescentes já haviam sido diagnosticados. No Brasil, não são poucos os dados sobre o diagnóstico do TDAH e a Ritalina que alimentam a polêmica. Periódicos de abrangência nacional, como as revistas Veja e Época e o jornal Folha de S. Paulo, têm abordado o tema continuamente. Em uma reportagem da Época, de dezembro de 2006, intitulada "Remédios demais? Os riscos enfrentados por crianças e adolescentes que tomam medicamentos psiquiátricos para tudo - de falta de atenção a mau comportamento", Segatto, Padilla e Frutuoso (2006) revelavam que, nos últimos cinco anos, ou seja, de 2002 a 2006, no Brasil, as vendas da Ritalina haviam triplicado.

Esses dados fazem parte da polêmica ética, moral, econômica e política criada em torno do TDAH. A discussão de cada um desses aspectos demandaria a escrita de outros artigos. Mas o panorama traçado oferece um pano de fundo que contextualiza esta discussão. Uma das preocupações do debate bio e neuroético atual em torno do TDAH diz respeito à separação entre o tratamento das patologias da atenção e a otimização das habilidades atentivas, requeridas principalmente pelo espaço ocupacional e escolar. Até onde estamos tratando de uma patologia? Quando estamos, buscamos a melhora do desempenho atentivo? Essas questões estão situadas no centro do debate sobre o diagnóstico do TDAH e de seu tratamento.

A diferença entre tratamento e otimização foi originalmente proposta no contexto da terapia genética por Sabin e Daniels (1994). O objetivo inicial era separar as intervenções que buscavam corrigir as deficiências do funcionamento genético normal e típico da espécie daquelas destinadas à sua otimização e maximização. Extrapolando a pesquisa genética, o termo enhancement technologies ${ }^{1}$ tem sido usado para descrever os tratamentos que visam a melhorar o desempenho, a aparência e o comportamento humano quando essa maximização não é considerada necessária em termos médicos.

A difícil distinção entre tratamento e otimização ganhou, sobretudo nos Estados Unidos, um caráter extremamente econômico, relacionado à decisão sobre o que deve ser ou não coberto pelos seguros de saúde. Ao discutirem

\footnotetext{
1 Embora não exista uma tradução para o português específica para o termo, poderíamos
} falar de tecnologias de melhoramento ou de aprimoramento do desempenho. 
algumas das responsabilidades neuroéticas atuais, Racine e Illes (2006) comentam que, pelo menos desde a explosão do uso do Prozac nos Estados Unidos, ouvimos falar da proliferação das drogas cosméticas, legitimadas por uma neurologia também cosmética. Ambas estão situadas nos espaços imprecisos estabelecidos entre as estratégias de tratamento e a otimização do desempenho e das (dis)funções cognitivas. Nos tópicos seguintes, analisaremos as fronteiras indefinidas que o diagnóstico do TDAH estabelece com as funções e disfunções da atenção e sua otimização.

\section{Um diagnóstico controverso}

Para Gordon e Keiser (1998), as controvérsias em torno do diagnóstico do TDAH nascem primeiramente de sua face interna. Os sintomas que definem o transtorno (desatenção, impulsividade e hiperatividade) são, em menor grau, traços comuns da natureza humana. Todo indivíduo é, em certa medida, um pouco desatento, impulsivo, desorganizado e nem sempre finaliza as tarefas almejadas, especialmente quando o sujeito em questão é uma criança de 6 ou 7 anos de idade.

Para os teóricos do TDAH do campo neuropsiquiátrico, o que diferencia a patologia da atenção e do autocontrole da normalidade e da 'superação positiva' do normal não é uma mudança qualitativa, mas uma mudança temporal e de intensidade. Esse é um aspecto extremamente controverso na definição do TDAH. Para que o diagnóstico seja definido, os sintomas devem ser quantitativamente anormais, e o que os tornam signos da patologia são suas intensidades.

Desde o início da década de 1980, sobretudo com a publicação da terceira edição do Diagnostic and Statistical Manual of Mental Disorders (APA, 1980), a psiquiatria tem priorizado a análise quantitativa em detrimento da qualitativa na definição dos transtornos mentais. Mas, ao assim fazê-lo, obscurece a distinção entre o que define por normal, anormal e melhor que normal. Essa mesma psiquiatria considera que o indivíduo com TDAH não se diferencia completamente do sujeito normal, ele apenas está um passo atrás no desenvolvimento de suas capacidades.

De acordo com Barkley (1997a), a criança ou o adulto com TDAH será sempre 'imaturo' no desenvolvimento da capacidade de persistência da atenção e do controle da ação quando comparado aos indivíduos de sua faixa de desenvolvimento. Mas, a decisão sobre o que é ser um indivíduo maduro ou 
imaturo, na mestria da atenção e do autocontrole, extrapola o campo científico, passando a ser, sobretudo, uma questão social e moral. Assim, essa decisão será sempre local e circunstancial, não sendo possível traçar linhas divisórias gerais e aplicáveis para todo e qualquer tipo de sociedade.

As dificuldades em traçar as distinções entre o desatento/hiperativo normal e o anormal são ainda maiores quando a lista de sintomas do TDAH é considerada. Em um dos mais preciosos estudos sociológicos sobre o TDAH, Rafalovich (2002) define o transtorno como uma pletora de sintomas diferenciados desde suas primeiras descrições. Partindo dessa definição e de outras que dela se aproximam, os principais críticos do TDAH repetem continuamente que um dos aspectos mais polêmicos desse distúrbio refere-se ao seu perfil pletora de sintomas. Sua classificação inclui tudo, e, portanto, o TDAH é um transtorno 'guarda-chuva' que não pode ser realmente visto a partir de uma descrição médica clara e unificada.

A descrição dos sintomas é extensa. O indivíduo com TDAH não é capaz de esperar. Quando envolvido em uma conversa, quebrando todos os códigos de etiqueta, ele, repetidamente, interrompe a fala do outro ou, então, não ouve o que este tem a dizer. O indivíduo TDAH é incapaz de integrar-se socialmente, e portanto sua vida social está sempre por um fio. Nele, a prudência e a reflexão necessárias à direção das ações mais importantes da vida são prejudicadas, por isso trata-se de um sujeito naturalmente propenso ao risco, que se direciona pela lógica do tudo ou nada, que não mede as consequências de suas ações. Para o discurso psiquiátrico dominante, essa tendência para o imediato não pensado e não refletido faz com que o produto do trabalho seja, na maior parte das vezes, insatisfatório. O comportamento hiperativo também se divide em diferentes signos, desde a manifestação de movimentos corporais excessivos e a incapacidade de permanecer sentado à agitação interior ou ansiedade constante.

Além disso, o problema da definição do diagnóstico agrava-se quando outros quadros patológicos, descritos na quarta edição do Diagnostic and Statistical Manual of Mental Disorders (APA, 1994), são considerados. Grande parte das patologias incluídas no manual psiquiátrico americano manifesta um problema de desatenção, de concentração e de impulsividade e um defeito de inibição.

$\mathrm{O}$ discurso psiquiátrico afirma que para diferenciar um indivíduo sem o transtorno do indivíduo com TDAH são feitas comparações. O desempenho produtivo, a adaptação social às exigências do seu entorno e a capacidade de autocontrole são confrontadas. Mas como definir cientificamente essa comparação? A suspeita em torno do diagnóstico do TDAH é também marcada pelo dilema 
metodológico da objetividade científica. Embora as imagens cerebrais tentem mostrar o contrário, a linha que separa o indivíduo com TDAH do sujeito normal é tão frágil e tênue que, na clínica e na esfera da vida prática, longe do ambiente laboratorial, não pode ser traçada e muito menos visualizada. Apesar dos avanços dos métodos de visualização cerebral, no dia a dia da prática diagnóstica, eles não revelam muita coisa. Até o momento, nenhum teste ou exame específico e preciso para a 'identificação' do TDAH foi definido. Seu diagnóstico continua sendo feito mediante um processo misto, que inclui testes psicológicos, história clínica, análise do desempenho escolar e entrevistas com pais e professores.

Quando se trata do adulto, a definição do diagnóstico do TDAH depende da avaliação subjetiva do sujeito afetado, que deve refletir a respeito de sua história de vida, desde os tempos mais remotos, e nela encontrar traços do TDAH. Além do paciente, outros informantes como pais, irmãos, cônjuges, colegas de trabalho, advogados e, em certos casos, até mesmo profissionais do trânsito, participam do processo de construção diagnóstica e da reconstrução da narrativa de vida individual. Mediante o preenchimento de questionários sobre o comportamento da pessoa diagnosticada ou de entrevistas com o médico, a opinião de tais informantes torna-se parte integrante da avaliação do paciente.

Na prática, a construção do diagnóstico do TDAH é mais bem descrita como um processo de negociação no qual opiniões diversas devem ser consideradas. Nem sempre essas negociações são pacíficas. Em muitos casos, as opiniões e os interesses das partes implicadas são divergentes: os informantes não estão de acordo entre si ou discordam da autoanálise do paciente; o médico não concorda com a avaliação do paciente e dos informantes e vice-versa. As pessoas podem estar convencidas de que têm a desordem antes de receberem o diagnóstico oficial ou, contrariamente, podem ser previamente resistentes a ele. Em todo caso, elas também participam ativamente da construção diagnóstica e sofrem profunda interferência desse processo.

Como afirma Berrios (1996), os diagnósticos psicopatológicos são constructos cujas fronteiras e limites dependem, em grande parte, da intenção de seus criadores e das pessoas neles enquadradas. Entretanto, entre os primeiros e os segundos nem sempre há acordos. Para os que lidam cotidianamente com o problema do TDAH, os indivíduos diagnosticados, suas famílias ou os profissionais de sua clínica, a pergunta sobre a existência real do transtorno é um prisma composto de muitas partes e sentidos, nem simples, nem autoevidente. Muitos elementos entram em jogo na decisão sobre o que é real, o que não é real, o que é patológico, o que é normal, e se o TDAH se inclui em um ou outro desses domínios. 
A distinção entre o sujeito desatento e hiperativo normal, o indivíduo com TDAH e aqueles que buscam a superação das suas capacidades cognitivas surge do envolvimento dos sujeitos implicados na avaliação diagnóstica, bem como das partes interessadas na pesquisa da atenção. Como demonstra Singh (2003, 2004), essa distinção resulta da mistura das expectativas pessoais, sociais, morais e econômicas presentes no processo de constituição do diagnóstico do TDAH. E, para que uma clínica diagnóstica do TDAH seja possível, todas essas expectativas devem ser analisadas, consideradas e problematizadas.

\section{Para além da clínica médica}

Na distância que separa e aproxima os indivíduos com TDAH dos sujeitos que buscam a otimização do desempenho atentivo, um espaço polêmico é constituído. Nele, alojam-se, também, as partes que, de dentro ou de fora do discurso médico, se interessam pelo controle e gestão da atenção e do comportamento. Dentre elas estão o mercado farmacológico; as forças armadas; o universo empresarial e sua demanda pelo aumento de produtividade e sucesso; o mercado esportivo; o espaço educacional; as partes diretamente implicadas no processo diagnóstico; e, de forma particular, o próprio indivíduo com TDAH, com suas demandas e seus dilemas existenciais e sociais.

Assim, foi também durante a década de 1990 que o debate sobre os direitos da criança com TDAH à reivindicação de serviços especiais conquistava novos espaços na legislação americana por intermédio da formulação do Americans with Disabilities Act of 1990 (ADA) e do The Individuals with Disabilities Education Act of 1997 (IDEA) (Gordon \& Keiser, 1998). Aclamado pelas associações americanas de pais e indivíduos com TDAH como um passo fundamental na conquista de seus direitos civis, o IDEA visava a garantir assistência financeira federal e local à educação especial de crianças com problemas de aprendizagem. Ser reconhecido como um 'indivíduo TDAH' tornava-se um direito civil vinculado à decisão judiciária.

O diagnóstico do TDAH foi legitimado pelo campo educacional e legal mediante a formulação e a aplicação dos direitos anteriormente descritos. Porém, ao mesmo tempo, o uso abusivo de tais ferramentas também alimenta o clima de suspeita em torno do diagnóstico, tornando ainda mais frágeis as linhas que separam a condição mórbida do desempenho normal da atenção e das tentativas de superação de seus limites. Vale lembrar que, no Brasil, já encontramos casos judiciários de pais que reivindicam condições especiais de ensino para os filhos 
com TDAH. Muitas vezes, tais condições também são válidas para crianças não diagnosticadas com TDAH, mas com desempenho educacional 'abaixo da média' ou ainda para aquelas que não exploraram plenamente seu potencial.

Os avanços psicofarmacológicos também participam da construção do lugar polêmico ocupado pelo diagnóstico do TDAH. A farmacologia desse transtorno confunde-se e por vezes identifica-se com as drogas cosméticas que buscam melhorar o desempenho cerebral. Os estimulantes são drogas que prometem aumentar a capacidade de concentração, de memória e de atenção, necessárias ao desenvolvimento do desempenho de produção. Em muitos casos, essas drogas são efetivas tanto em pessoas acometidas pelo TDAH quanto em indivíduos normais, insatisfeitos com seu baixo rendimento profissional e acadêmico. Como Elliot (1999), Singh (2005) e Racine e Illes (2006) comentam, pesquisas atuais têm demonstrado que o uso recreativo de metilfenidato, especialmente da Ritalina, na otimização do desempenho acadêmico e profissional tem crescido surpreendentemente.

Em setembro de 2004, a revista The Economist publicava que ao menos 40 novas drogas cosméticas estavam sendo desenvolvidas e já estavam sendo anunciadas no mercado. Na lista, incluíam-se medicamentos que prometiam ser mais efetivos que a Ritalina e de menor potencial aditivo, como o Provigil e o Alertec, que, nos Estados Unidos, em 2003, alcançaram o número de US\$ 290 milhões em vendas. Essas drogas situam-se na fronteira da distinção já comentada, ora pensadas como tecnologias de otimização, ora incluídas na lista das descobertas milagrosas contra patologias específicas como o TDAH (Supercharging, 2004).

Na linha tênue que separa o TDAH das tecnologias de otimização da atenção, situamos também a relação histórica entre a pesquisa da atenção e os interesses das Forças Armadas. Taylor (1995) mostra como o retorno do interesse pelo estudo da atenção, na segunda metade do século XX, resultou de uma demanda social e militar do pós-guerra. O estudo dos mecanismos atentivos tornava-se uma necessidade prática. Na National Aeronautics and Space Administration (Nasa), os eletroencefalogramas eram utilizados pelos cientistas na avaliação da capacidade de focalização e vigilância de seus astronautas.

Desde a Segunda Guerra Mundial, o uso de anfetaminas pelos pilotos da Força Aérea americana tem sido uma prática comum, e, há décadas, o US Air Force Fatigue Countermeasures Branch, equipe de pesquisadores americanos responsável por desenvolver estudos e pesquisas para combater os riscos da fatiga para a segurança aérea, tem estudado os efeitos da privação do sono na 
diminuição dos estados atentivos. Um número cada vez maior de programas de pesquisa destinados ao estudo das farmacologias da atenção tem sido financiado pelas forças militares. Recentemente, o governo francês sugeriu que a Legião Estrangeira fizesse uso de uma forma de Modafinil durante algumas de suas operações. Essa mesma droga, também indicada para o tratamento do TDAH, vem sendo investigada pelas forças militares americanas. Uma grande polêmica em torno do Modafinil foi criada quando, dez dias antes do início das Olimpíadas de 2004, a World Anti-Doping Agency adicionou o medicamento à lista das substâncias proibidas. Não são poucas as controvérsias a respeito de drogas que podem ser comparadas tanto à ilícita cocaína como a uma inofensiva taça de café ou a um elixir milagroso, e cuja recomendação é feita para uma lista de indivíduos que inclui os soldados americanos e franceses, os diretores executivos das maiores empresas do mundo e os indivíduos com TDAH. Se, em muitos casos, tais controvérsias são excessivamente panfletárias e mal fundamentadas, também contribuem para a constituição de uma postura mais responsável diante da clínica diagnóstica do TDAH e de sua terapêutica. Além disso, também ajudam a problematizar as atuais tecnologias de otimização da atenção, as premissas que as sustentam e suas consequências para a vida humana.

\section{Desafios Neuroéticos}

Novos diagnósticos médicos e psiquiátricos raramente emergem e se legitimam apenas como resultados de descobertas científicas; eles são um produto de circunstâncias históricas e sociais complexas, internas e externas ao campo médico. O diagnóstico do TDAH, como comentam Rose $(2000,2003)$ e Novas e Rose (2000), emergiu em um momento histórico no qual as linhas divisórias entre o normal e o patológico foram dissolvidas e transformadas em um contínuo somático, ou seja, o que difere o normal do anormal não são mais traços qualitativos. Em certo sentido, eles compartilham a mesma soma, o mesmo 'bios', mas que podem ser são mais ou menos maduros, mais ou menos atrasados ou desenvolvidos. É nesse sentido que o indivíduo com TDAH é imaturo em seu desenvolvimento cerebral quando comparado a um indivíduo 'normal'.

Nesse contínuo somático, o indivíduo TDAH ocupa um espaço ambíguo. Ele pode ser encontrado em polos tão diversos como o das celebridades executivas ou do marginal criminoso. Um dos resultados da configuração fronteiriça que define o TDAH é um traço comum, biológico, cerebral e epidemiológico, 
mas também moral, social e existencial, criado, por um lado, entre a criança com TDAH, o criminoso, o dependente químico, o deprimido, o motorista imprudente, e o indivíduo patologicamente instável, e, por outro lado, o indivíduo bem-sucedido, tenaz em suas decisões, o acadêmico produtivo e as pessoas que se orientam pelas regras da vida saudável. Vinculando-os está a maior ou menor capacidade de autocontrole e gestão da atenção.

O diagnóstico do TDAH constituiu-se no cerne de uma sociedade na qual o indivíduo bem-sucedido, produtivo e feliz é o autogestor atento, consciente, racional e prudente. Nessa sociedade, não há limites para as exigências de atenção, e, na busca pela maximização da atenção, todo indivíduo acabará sendo um pouco desatento. Ao mesmo tempo, a psicofarmacologia atual afirma que logo não haverá limites para a intensificação da atenção. A lógica das individualidades somáticas, corrigíveis e manipuláveis nos diz que tudo é possível. O transtorno da atenção e do autocontrole legitimou-se, nesse contexto, quando as limitações corporais e cerebrais da atenção foram parcialmente eliminadas. Porém, é a análise neuroética desse mesmo transtorno que nos impõe o questionamento sobre os limites médicos e éticos das tecnologias de otimização e tratamento da (des)atenção.

Ao analisarem os desafios neuroéticos trazidos pelo desenvolvimento das novas tecnologias de otimização da memória e da atenção, Racine e Illes (2006) identificam ao menos quatro atitudes éticas que, a nosso ver, deveriam ser consideradas pelos profissionais que lidam com o TDAH e incorporadas em sua clínica. São elas:

a) o esclarecimento aos pacientes e familiares sobre os limites e as consequências biológicas, psicológicas e sociais do uso das drogas situadas nas fronteiras entre as estratégias de otimização e o tratamento da (des) atenção;

b) no caso da Ritalina, em particular, a análise da vulnerabilidade das crianças e adolescentes diagnosticados, especialmente no que diz respeito à pressão social, familiar e escolar;

c) a identificação das causas e expectativas individuais e sociais que sustentam a suspeita (ou mesmo o desejo) da existência do diagnóstico;

d) o esclarecimento sobre os usos eticamente 'aceitáveis' do tratamentootimização indicado, com o intuito de prevenir possíveis abusos. 
A prática diagnóstica e terapêutica do TDAH não é simples, nem tampouco óbvia. Defender a existência biológica do transtorno e privilegiar a terapêutica medicamentosa não exime o médico, o psicólogo, o profissional da saúde ou da educação de considerarem todos os aspectos, individuais, econômicos, morais e sociais envolvidos em sua clínica. Este é o desafio que o diagnóstico do TDAH impõe aos profissionais da saúde, que devem alimentar a discussão neuroética, levantando dilemas, no dia a dia da clínica do TDAH, que podem construir um debate mais empírico, comprometido com a realidade dos envolvidos direta e indiretamente no lidar com o transtorno. O problema das distinções entre as funções e disfunções da atenção e sua otimização está situado no centro do diagnóstico do TDAH. Ele se refere à complicada distinção médica, ética e moral entre o funcionamento normal e patológico da atenção e do autocontrole, mas também tangencia as estratégias neurocientíficas atuais para superar o estado normal da atenção, otimizá-lo e ir além de seus limites. O diagnóstico do TDAH constituiu-se no interior desse campo híbrido, alimenta-se dele ao mesmo tempo que é por ele fragilizado. Em todo caso, a análise do TDAH como um diagnóstico limítrofe é o desafio neuroético colocado à sua clínica diagnóstica e terapêutica.

\section{Referências}

AMERICAN PSYCHIATRIC ASSOCIATION (APA). Diagnostic and Statistical Manual of Mental Disorders. 3. ed. Washington:American Psychiatric Association, 1980.

AMERICAN PSYCHIATRIC ASSOCIATION (APA). Diagnostic and Statistical Manual of Mental Disorders. 4. ed. Washington:American Psychiatric Association, 1994.

BARKLEY, R. A. ADHD and the Nature of Self-Control. London:The Guilford Press, 1997a. BARKLEY, R. A. Behavioral inhibition, sustained attention, and executive functions: constructing a unifying theory of ADHD. Psychological Bulletin, (1)121:65-94, 1997b.

BARKLEY, R. A. Developmental course, adult outcome, and clinic-referred ADHD adults. In: BARKLEY, R. A. (Ed.). Attention Deficit Hyperactivity Disorder: a handbook for diagnosis and treatment. New York: Guilford Press, 1998.

BERRIOS, G. E. The History of Mental Symptoms - descriptive psychopathology since the nineteenth century. Cambridge: Cambridge University Press, 1996.

DEGRANDPRE, R. Ritalin Nation: rapid-fire-culture and the transformation of human counciousness. New York:W. W. Norton \& Company, 2000. 
EBERSTADT, M. Why Ritalin rules. Policy Review, 94, 1999. Disponível em: <www.policyreview.org>. Acesso em: 20 jul. 2004.

ELLIOT, C. A Philosophical Disease: bioethics, culture and identity. London: Routledge, 1999.

GORDON, M. \& KEISER, S. Accommodations in Higher Education under the Americans with Disabilities Act (ADA): a no-nonsense guide for clinicians, educators, administrators, and lawyers. New York: The Guilford Press, 1998.

HALLOWELL, E. M. \& RATEY, J. J. Tendência à Distração: identificação e gerência do distúrbio do déficit de atenção (DDA) da infância à vida adulta [1994]. Tradução de A. Carvalho. Rio de Janeiro: Rocco, 1999.

KÖNNEKER, C. Zappelige Zeiten. Gehirn \& Geist Dossier, 3: 3, 2004.

LAKOFF, A. Adaptive will: the evolution of attention deficit disorder. Journal of the History of the Behavioral Sciences, 2(36): 149-169, 2000.

MATZA, L.; PARAMORE, C. \& PRASADA, M. A review of the economic burden of ADHD. Cost Effectiveness and Resource Allocation, 5(3): 1-9, 2005. Disponivel em: <www. resource-allocation.com/content/3/1/5>. Acesso em: 15 nov. 2005.

MEETING OF MINDS. European Citizen's Deliberation on Brain Science. Dresden: Nationaler Bürgerbericht aus Deutschland, 2005.

NOVAS, C. \& ROSE, N. Genetic risk and the birth of the somatic individual. Economy and Society, 29(4): 485-513, 2000.

RACINE, E. \& ILLES, J. Neuroethical Responsibilities. Canadian Journal of Neurological Sciences, 33: 269-277, 2006.

RAFALOVICH, A. Framing ADHD Children: a critical examination of the History, discourse, and everyday experience of attention deficit/hyperactivity disorder. Latham: Rowman \& Littlefield-Lexington, 2004.

ROSE, N. The biology of culpability: pathological identity and crime control in a biological culture. Theoretical Criminology, 1(4): 5-34, 2000.

ROSE, N. The neurochemical self and its anomalies. In: DOYLE, A. (Ed.). Risk and Morality. Toronto: University of Toronto Press Incorporated, 2003.

SABIN, J. \& DANIELS, N. Determining "medical necessity" in mental health practice. Hastings Centre Report, 24, (6), 5-13, 1994.

SEGATTO, C.; PADILLA, I. \& FRUTUOSO, S. Remédios demais? Os riscos enfrentados por crianças e adolescentes que tomam medicamentos psiquiátricos para tudo - de falta de atenção a mau comportamento. Época, 446: 108-115, 2006. 
SINGH, I. Boys will be boys: fathers' perspectives on ADHD symptoms, diagnosis, and drug treatment. Harvard Review of Psychiatry, 11(6): 308-316, 2003.

SINGH, I. Doing their jobs: mothering with Ritalin in a culture of mother-blame. Social Science \& Medicine, 59: 1193-1205, 2004.

SINGH, I. Will the "real boy" please behave: dosing dilemmas for parents of boys with ADHD. The American Journal of Bioethics, 5(3): 34-47, 2005.

SUPERCHARGING the brain. The Economist, 16 set. 2004, p. 1-5. Disponível em: <www. economist.com/science/tq/displayStory.cfm?story_i d=3171454>.

TAYLOR, E. Dysfunctions of attention. In: CICCHETTI, J. (Ed.). Developmental Psychopathology - risk, disorder, and adaptation. New York: John Wiley \& Sons, 1995. v. 2. 


\title{
12
}

\section{Manejo do Paciente Usuário de Drogas Vivendo com HIV/Aids}

\author{
Mônica Malta \\ Francisco Inácio Bastos \\ Maristela Monteiro
}

Desde o início da epidemia de HIV/Aids, o uso de substâncias ilícitas tem estado estreitamente associado à disseminação do HIV, o vírus transmissor da Aids, além de outros agentes infecciosos de transmissão sanguínea e sexual, como os vírus das hepatites B e C. O cenário das drogas na América Latina tem como principal substância psicoativa ilícita consumida a cocaína, em suas diferentes modalidades, como a cocaína em pó e a cocaína fumada, sob a forma de crack e similares. Em virtude dos padrões específicos do consumo dessas substâncias - uso constante e repetitivo em um único dia - e dos custos elevados associados ao consumo habitual, seus usuários muitas vezes se envolvem em comportamentos de risco para manter e financiar seu consumo (Inciardi \& Surratt, 2001; Latkin, Knowlton \& Sherman, 2001). Muitos desses usuários envolvem-se em sexo comercial ('trocado' por dinheiro, drogas ou outros bens e favores), tráfico e furtos, não têm moradia fixa ou vivem em abrigos. E muitos sobrevivem - parcial ou totalmente - da venda ou repasse dessas drogas e outros atos ilícitos (Surratt, 2000).

Tais comportamentos de risco encontram-se presentes no estilo de vida de usuários de cocaína em geral (cocaína inalada, crack e cocaína injetável). Os usuários de cocaína injetável, entretanto, geralmente apresentam riscos adicionais diante do HIV e da AIDS e demais infecções transmissíveis sexualmente ou através do sangue. Esses usuários também apresentam um padrão de uso 
de droga bastante frequente, injetando-se de forma constante e repetitiva em um único dia. Tal padrão de uso (binge, em inglês, sem tradução para a nossa língua) favorece a adoção de hábitos de maior risco, como o compartilhamento e/ou a reutilização de seringas e agulhas usadas e o uso de água suja, eventualmente contaminada, para diluir a cocaína.

A interação entre esses padrões de uso de cocaína e comportamentos sexuais de risco (sexo desprotegido, múltiplos parceiros e envolvimento em sexo comercial) coloca essa população sob risco acrescido diante do HIV/Aids, demais infecções sexualmente transmissíveis e doenças transmissíveis através do sangue.

Usuários de drogas vivendo com HIV/Aids possuem um risco maior de apresentar complicações ao longo do seu processo de tratamento. Esses pacientes, por exemplo, precisam ter acesso a exames laboratoriais mais sofisticados (como a genotipagem do HIV) e a regimes terapêuticos mais modernos e complexos (como as 'terapias de resgate', adequadas para pacientes com cepas virais multiresistentes ou falha terapêutica), em função da falência de alternativas de tratamentos mais simples e baratos. Precisam, também, com frequência, de serviços de apoio social (alojamentos, encaminhamento para auxílios governamentais etc.), suporte psicológico (grupos de apoio e terapia individual) e tratamento para diferentes comorbidades psiquiátricas.

Contraditoriamente, esses pacientes, que costumam demandar cuidados complexos e serviços de suporte diversos, veem-se às voltas com dificuldades substanciais ao buscarem tratamento na área da saúde. Os aconselhamentos pré-teste e pós-teste são, muitas vezes, inadequados, e o suporte psicossocial encontra-se aquém do desejado e necessário. Não raro, esses pacientes recebem um acompanhamento clínico inadequado às suas necessidades específicas e têm sua indicação para início da terapia antirretroviral de alta potência (HAART) postergada - adiamento este que pode comprometer uma melhor resposta do paciente ao tratamento e, portanto, influenciar, negativamente, sua qualidade de vida.

Os usuários de drogas vivendo com HIV/Aids necessitam de uma assistência que inclua atenção básica em saúde, atenção especializada para HIV/Aids, tratamento para dependência química e serviços de apoio psicossocial. Por essas razões, os serviços que os assistem devem propor e implementar estratégias que sejam integrais, inovadoras e adequadamente coordenadas - meta ideal, porém muitas vezes difícil no contexto do Sistema Único de Saúde (SUS), o qual costuma ser caracterizado pela escassez de profissionais qualificados e de 
serviços adequados para atender a essa população e às demais populações com necessidades especiais.

Caso estratégias inclusivas e adequadas não sejam prontamente desenvolvidas e disponibilizadas, a redução na morbimortalidade, que tem sido observada em outras populações de pessoas vivendo com HIV/Aids, provavelmente não será alcançada entre os usuários de drogas que vivem com HIV/Aids.

Apesar das evidências epidemiológicas que fundamentam a associação entre o uso de substâncias psicoativas e a infecção pelo HIV (Unaids/WHO, 2011; Pechansky et al., 2006; Stvilia et al., 2006; Santibanez et al., 2006) e dos dados que indicam que os usuários de drogas tendem a ter um acesso, aquém do necessário, ao tratamento anti-HIV e AIDS (Vlahov \& Celentano, 2006; Broadhead et al., 2002; Kalichman et al., 2002), tem havido até o momento poucos esforços para integrar o atendimento médico para o HIV/Aids ao atendimento para a dependência química.

Diversos estudos evidenciaram que os usuários de drogas vivendo com HIV/Aids que recebem uma assistência integrada - incluindo tratamento para dependência química, suporte em saúde mental, assistência social e tratamento para a infecção pelo HIV - apresentam, de um modo geral, bons padrões de aderência à HAART, com uma consequente melhora de seu estado de saúde e de sua qualidade de vida como um todo (Clarke et al., 2002; Broadhead et al., 2002; Agins et al., 2001; Martin et al., 2001; Knowlton et al., 2001).

Apresentamos aqui, de forma bastante resumida, os princípios básicos que embasaram a elaboração de um manual publicado pela Organização Pan-Americana da Saúde (Opas), o qual objetiva nortear o manejo de usuários de drogas vivendo com HIV/Aids (Opas/OMS, 2006). A elaboração de manuais e demais publicações que contribuam para elevar os padrões de assistência para essa população objetiva melhorar não só a prática cotidiana dos profissionais da saúde, mas, sobretudo, a qualidade de vida dos usuários de drogas, de seus familiares e das pessoas que lhes são próximas.

A elaboração de intervenções voltadas para usuários de drogas vivendo com HIV/Aids deve ser norteada por três princípios-chave:

- Tanto a dependência química quanto a infecção pelo HIV podem ser prevenidos e devidamente tratados;

- Todos os usuários de drogas vivendo com HIV/Aids devem receber uma assistência abrangente e de qualidade; assim como quaisquer outros 
indivíduos que busquem tratamento para o HIV/Aids e/ou para o uso problemático de drogas ou álcool;

- Os serviços devem ser oferecidos de uma maneira amigável, que encoraje o engajamento e a retenção do paciente no tratamento.

Com base nesses princípios-chave, algumas orientações básicas podem facilitar a elaboração e uma melhor adequação dos serviços de saúde disponíveis para essa população.

Primeiramente, é fundamental que os serviços de saúde sejam integrados. Os usuários de drogas vivendo com HIV/Aids têm uma ampla gama de necessidades, que costumam ser atendidas por serviços de saúde distintos. Para estimular a permanência do paciente nesses diferentes serviços e abordar de forma eficaz suas múltiplas necessidades, serviços de atendimento a portadores de HIV/Aids e de tratamento para dependência química, saúde mental e suporte social devem agir de forma integrada e coordenada. Em um contexto ideal, os diferentes serviços deveriam estar disponíveis em um único local. Entretanto, esse modelo é difícil de ser alcançado em face dos escassos recursos financeiros e humanos. Para superar essa dificuldade, é importante que os diferentes serviços estabeleçam canais de comunicação ágeis entre si e protocolos de cooperação claros e plenamente operacionais, a fim de permitir que os pacientes encaminhados realmente recebam o atendimento necessário, em tempo hábil.

A contínua avaliação do estado de saúde - tanto de usuários já infectados pelo HIV como de pessoas que usam drogas e tenham comportamentos de risco frente ao vírus - constitui um aspecto fundamental de qualquer programa voltado para essa população. A avaliação sistemática desses pacientes permite intervenções mais ágeis quando da emergência de algum problema, além de facilitar a educação e o aconselhamento contínuo. Essa avaliação periódica é importante, pois pessoas que usam drogas podem vir a contrair o HIV ou outros vírus/infecções transmitidas pelo sangue ou sexo, necessitando, por isso, de tratamentos concomitantes para diferentes problemas de saúde. Além disso, é possível que pessoas vivendo com HIV/Aids comecem a usar substâncias psicoativas, podendo necessitar de um atendimento para a dependência química em paralelo ao seu tratamento anti-HIV/Aids.

Outro aspecto a ser salientado é a necessidade do contínuo treinamento e da supervisão da equipe de saúde, aliados a uma constante avaliação da qualidade dos serviços prestados, que ampliam e agilizam o acesso aos pacientes e a aderência destes ao tratamento, contribuindo, consequentemente, para 
melhorar tanto a qualidade de vida do paciente quanto a satisfação profissional da equipe envolvida.

Também é importante observar que a qualidade dos serviços prestados deve ser monitorada. Os protocolos para tratamento de usuários de drogas vivendo com HIV/Aids devem ser revisados e atualizados, e por isso é importante que os serviços organizem, regularmente, rodadas de treinamento e oficinas que permitam a atualização dos conhecimentos e a discussão e eventual revisão das práticas dos profissionais da saúde.

A organização de reuniões de equipe regulares é vista, em muitos trabalhos, como uma estratégia fundamental para integrar a equipe e para melhorar a assistência fornecida ao paciente.

A educação dos pacientes constitui uma ferramenta importante para elucidar e discutir mitos e crenças errôneas sobre o HIV e a Aids e sobre a dependência química e para fornecer aos pacientes informações adequadas a respeito da redução ou eliminação de comportamentos de maior risco para a saúde, prevenção e mudanças comportamentais. As práticas educativas devem ter um caráter interativo, e não meramente informativo, e se inscrevem no marco mais amplo da promoção da saúde.

A confidencialidade é uma orientação básica de extrema relevância. Diversos estudos apontam que o estigma - tanto relacionado ao status HIV-positivo quanto ao consumo de drogas - pode representar uma importante barreira para a identificação e o tratamento dessa população. O estabelecimento de normas claras de conduta a respeito do sigilo e da privacidade pode minorar a hesitação e a angústia do paciente em procurar atendimento e revelar seu status relacionado ao HIV ou à dependência química.

O envolvimento ativo dos pacientes é fator primordial para o estabelecimento de uma assistência de qualidade. Priorizar as necessidades e especificidades da população atendida e estimular o envolvimento de pacientes na implantação e no efetivo desenvolvimento de serviços mais adequados constituem aspectos importantes, uma vez que permitem um diálogo mais aberto e franco entre o serviço e a população atendida, auxiliando tanto profissionais como pacientes a estabelecerem uma relação produtiva e colaborativa. Pacientes são muito mais propensos a aderirem a serviços nos quais suas preferências e necessidades são ouvidas e levadas em conta. 


\section{Aderência}

Tendo em vista a importância de se estimular o acesso de usuários de drogas vivendo com HIV/Aids a uma ampla gama de serviços, é necessário que se elaborem estratégias voltadas para ampliar esse acesso e para integrar as diferentes iniciativas. No entanto, uma discussão mais aprofundada sobre as diferentes estratégias recomendadas para o manejo desses pacientes foge ao escopo do presente texto. Priorizamos, portanto, a discussão sobre os aspectos-chave relacionados à aderência ao tratamento, por considerarmos a baixa aderência um problema sério, tanto no manejo da dependência química como no manejo da infecção pelo HIV entre dependentes químicos.

A terapia antirretroviral de alta potência (cuja sigla, em inglês, HAART, é universalmente adotada) engloba o uso de diversos medicamentos e tornou-se o tratamento padrão para alcançar a máxima supressão viral entre indivíduos vivendo com HIV/Aids. Além de proporcionar uma vida mais longa à pessoa vivendo com HIV/Aids, a HAART proporciona também um aumento na sua qualidade de vida, relacionada diretamente a uma melhor condição física e emocional (Cunningham et al., 2005). Porém, embora os regimes medicamentosos atuais sejam principalmente compostos de poucas pílulas e doses, esquemas terapêuticos direcionados a pacientes em falha terapêutica ou infectados com cepas virais multirresistentes tendem a ser mais complexos. Os medicamentos antirretrovirais não podem ser esquecidos ou usados de forma irregular. O período de tempo durante o qual os medicamentos permanecem ativos na corrente sanguínea e a interação desses medicamentos com alimentos e outros medicamentos fazem com que a constância, a observação dos horários de doses e a regularidade sejam fatores essenciais para a eficácia do tratamento. O fato de pular apenas algumas poucas doses pode levar a um aumento na replicação do HIV. Como são muito frequentes as mutações desse vírus, o aumento na sua replicação pode, rapidamente, levar a uma resistência ao medicamento utilizado e à consequente falha terapêutica, ou seja, à incapacidade de o medicamento específico combater, de fato, o vírus.

Do ponto de vista do indivíduo, uma eventual falha terapêutica pode significar a perda da oportunidade de utilização de um regime medicamentoso extremamente eficaz, capaz até de tornar a carga viral do HIV tão baixa a ponto de ser indetectável nos exames laboratoriais atualmente disponíveis.

A consequência mais ampla da falha terapêutica, do ponto de vista da saúde pública, é a possível disseminação, na comunidade, de cepas (variantes) 
virais multirresistentes, ou seja, resistentes a diversos medicamentos. Por isso, é importante, tanto para o indivíduo quanto para a comunidade, ter a certeza de que estejam disponíveis os serviços de apoio necessários para aumentar a aderência ao tratamento.

Portanto, a aderência do paciente ao tratamento antirretroviral é parte fundamental do manejo clínico da infecção pelo HIV/Aids, uma vez que a não aderência à HAART está diretamente relacionada ao desenvolvimento da resistência viral, da consequente falha terapêutica e do surgimento de cepas virais multirresistentes. Para alertar sobre um possível aumento dos níveis de não aderência nos países pobres, teoricamente menos capazes de garantir o acesso a medicamentos tão caros, a complexidade dos esquemas antirretrovirais tem sido garantida por prescrições e orientações adequadas, por parte dos serviços de saúde, e pelo cumprimento também adequado, por parte dos pacientes, das regras acertadas em comum acordo com os profissionais da saúde (Jaffar et al., 2005).

Um dos fatores-chave para que o desenvolvimento de estratégias voltadas para a aderência à HAART seja bem-sucedido é que exista uma cooperação constante entre as 'pessoas que tomam os medicamentos e as que prescrevem os medicamentos'. Uma colaboração singular, em que cada uma das pessoas envolvidas no processo respeite a dignidade e a integridade da outra, mesmo que os conhecimentos, estilos de vida ou escolhas pessoais de cada um sejam diferentes.

É necessário ressaltar ainda que alguns pacientes podem não responder à HAART apesar de seguirem à risca as prescrições e terem uma aderência excelente ao tratamento. Este é, particularmente, o caso de pacientes que já passaram por múltiplos regimes terapêuticos, ou dos que possuem problemas de máabsorção (dos medicamentos ou dos alimentos de uma forma geral), ou, ainda, dos que estão infectados com cepas virais multirresistentes do HIV.

\section{Quem precisa de ajuda para aderir à HAART?}

Médicos, enfermeiros, assistentes sociais e outros profissionais da saúde não dispõem de elementos para identificar de forma clara e precisa qual será a aderência de um paciente à HAART ao longo do seu tratamento. Por isso, "previsões' e ‘suposições' sobre a possível não aderência de determinado paciente não devem ser utilizadas como critério de exclusão de qualquer indivíduo que tenha indicação para começar a HAART. Isso se sobretudo tais suposições não se baseiam em dados científicos, mas sim na intuição e em ideias preconcebi- 
das. Como se sabe, ideias que temos de antemão muitas vezes estão próximas de preconceitos e lugares-comuns.

Geralmente, o esquema antirretroviral inclui três medicamentos diferentes, tomados em doses que variam entre duas e três vezes ao dia. Muitos medicamentos precisam ser tomados com alimentos, outros sem alimentos; alguns medicamentos não podem ser tomados junto com outros, e alguns exigem a ingestão de uma grande quantidade diária de líquidos. Mesmo quando esquemas terapêuticos com doses únicas estiverem disponíveis, quase todos os pacientes enfrentarão, em alguma medida, dificuldades em aderir aos esquemas prescritos e precisarão de algum tipo de apoio para uma terapia que se estenderá para o resto da vida.

É importante ressaltar que a não aderência (em algum grau) constitui um fenômeno universal. Diversos estudos mostram que algum grau de não aderência ocorre tanto em países ricos como em países pobres e nos mais diversos grupos populacionais. A não aderência está presente no tratamento de diversas doenças crônicas, inclusive no tratamento de problemas de saúde que possam determinar riscos de vida, como é o caso do diabetes ou da hipertensão arterial grave, além da infecção pelo HIV (Orrell, 2005; Moatti, Spire \& Kazalchkine, 2004; Remien et al., 2003; Bamberger et al., 2000).

Portanto, algumas questões são importantes para a avaliação e o acompanhamento da aderência de cada paciente ao longo de seu tratamento antirretroviral. Destacamos a seguir alguns dos princípios básicos que devem nortear o cuidado de pessoas vivendo com HIV/Aids.

- A aderência ao tratamento deve ser reavaliada a cada consulta, de forma a ser possível identificar qualquer problema e/ou dificuldade no decorrer do tratamento antirretroviral, permitindo a formulação e discussão de estratégias necessárias para melhorar a aderência.

- O esquema terapêutico adotado deve ser explicado em linguagem acessível e adequada ao universo educacional e cultural do paciente. Em cada etapa do diálogo com o paciente, o profissional de saúde deve verificar se ele compreendeu, de fato, as informações dadas, evitando com isso que o paciente tenha compreensões errôneas sobre como/ quando tomar cada medicamento ou que ele apenas diga que compreendeu para ser agradável ou parecer bem-educado.

- A utilização de folhetos com fotos dos remédios ou desenhos colados nas embalagens dos medicamentos indicando o horário em que devem 
ser tomados constitui uma boa estratégia para evitar/reduzir o esquecimento. Outra dica é colar desenhos de alimentos/água para lembrar se o remédio deve ser tomado junto com a alimentação ou com uma boa quantidade de líquidos. Essas e outras estratégias facilitam a compreensão do esquema terapêutico e ajudam a fixar e identificar as especificidades de cada medicamento e suas modalidades de uso.

- Antes de iniciar o tratamento antirretroviral, é necessário avaliar em conjunto com o paciente sua motivação em tomar os medicamentos de forma apropriada, além de identificar se o esquema prescrito está adequado ao seu estilo de vida.

- Algumas vezes é útil fazer uma experiência inicial para verificar no dia a dia como o paciente tomará os medicamentos, utilizando, para isso, balas/jujubas como se fossem medicamentos. Após essa primeira etapa, uma nova consulta deverá avaliar como foi a experiência de tomar os "medicamentos-balas", analisando os impasses encontrados e elaborando estratégias para superar as dificuldades relatadas.

- Os possíveis efeitos colaterais do esquema terapêutico escolhido devem ser discutidos com cada paciente antes do início da HAART. Isso evitará que o doente se assuste com problemas que surjam inesperadamente e interrompa seu tratamento ao se deparar com efeitos colaterais desconhecidos. Além de minimizar esse elemento surpresa, essa tática possibilita a formulação de estratégias de esclarecimento e enfrentamento, caso os efeitos colaterais sejam identificados pelo paciente e/ ou por seu médico.

- Alguns medicamentos podem causar náuseas e/ou ânsia de vômitos. O paciente que estiver ciente disso poderá ter em casa algum medicamento eficaz para combater esse efeito colateral (que não apresente nenhuma interação medicamentosa com o esquema HAART).

- Alguns medicamentos podem causar lipodistrofia (distribuição desigual de gordura no corpo), por isso pacientes em tratamento com esse tipo de medicamento devem iniciar um esquema de exercícios físicos que ajudem a prevenir esse efeito colateral.

A aderência ao tratamento é fundamental para o sucesso da terapia antirretroviral. Uma aderência aquém da necessária pode levar ao desenvolvimento de 
cepas virais multirresistentes, falha terapêutica e uma consequente piora imunológica e clínica do indivíduo. A aderência do paciente é geralmente maior com relação a esquemas terapêuticos simplificados, bem tolerados pelo organismo e que envolvam o menor número possível de pílulas por dia.

Os pacientes devem receber um aconselhamento adequado antes de começarem seu tratamento HAART, e esse aconselhamento deve abordar os seguintes assuntos: os benefícios esperados do tratamento; os possíveis efeitos colaterais; as possíveis interações medicamentosas (com pílulas anticoncepcionais, medicamentos utilizados no tratamento da tuberculose entre outros); a importância do diálogo franco entre paciente e equipe de saúde; a possibilidade de o paciente se comprometer a iniciar um tratamento que, possivelmente, vá durar por toda a sua vida; e a importância da aderência ao tratamento e os riscos da falha terapêutica. A utilização de materiais visuais (folhetos, fotos, livretos com linguagem acessível e revistas sobre o tema) costuma ser muito útil nessa etapa de preparação para o início do tratamento antirretroviral. A participação em grupos de aderência e o diálogo com outros pacientes que já estejam em terapia HAART costumam ser outra opção esclarecedora e fundamental para os pacientes que desejam iniciar o tratamento.

\section{Avaliação da aderência à HAART}

A avaliação da aderência à HAART é difícil, pois nenhum dos métodos disponíveis se utilizados isoladamente é capaz de fornecê-la com exatidão. Algumas das medidas utilizadas são o relato do próprio paciente, a contagem de pílulas, a medição da concentração de medicamento na corrente sanguínea, o monitoramento por aparelhos eletrônicos e as estimativas do médico.

É fundamental que qualquer avaliação médica não se baseie exclusivamente em impressões subjetivas, mas conte sempre com dados clínicos objetivos e uma avaliação do impacto do tratamento sobre os marcadores biológicos, medidos por meio de exames laboratoriais. Na infecção pelo HIV, os principais marcadores biológicos são a contagem de células CD4+ e a carga viral. A princípio, um tratamento bem-sucedido deve determinar uma elevação das células de defesa do organismo (sobretudo as CD4+) e uma redução e controle da replicação (reprodução) do vírus, com a consequente redução da carga viral.

Em contextos nos quais esses exames laboratoriais não estão disponíveis, é possível fazer uma estimativa da melhora ou piora do estado imunológico do 
paciente por meio da contagem total de linfócitos (células sanguíneas de defesa) realizada periodicamente.

Todos os métodos de avaliação da aderência possuem vantagens e desvantagens, e, uma vez que nenhum método foi identificado, até o momento, como sendo o melhor, é muito importante que se utilizem simultaneamente e de forma integrada diferentes métodos, de modo que se obtenha a melhor avaliação possível da aderência à HAART. Seguem alguns dos métodos mais eficazes para comprovação da aderência ao tratamento:

AutORRElATO: o relato do próprio paciente sobre sua aderência ao tratamento geralmente superestima a aderência. Porém, pode representar um retrato bastante fiel da tomada de medicamentos, uma vez que tenha sido estabelecida uma relação franca e honesta entre o paciente e seu médico. A avaliação da aderência pode se basear na lembrança que o paciente tem do número de vezes que tomou os medicamentos nos últimos três dias, na última semana, no último mês ou da última dose de medicamentos que ele tenha pulado. É importante ressaltar que alguns indivíduos podem não se sentir à vontade para contar ao seu próprio médico que pularam uma ou mais doses dos medicamentos. Muitos pacientes tendem a dizer aquilo que acham que os médicos querem ouvir e não o que realmente está acontecendo. Um serviço de saúde ideal é aquele no qual o doente se sinta seguro e à vontade para relatar que deixou de tomar algumas doses de seus medicamentos. Caso haja constrangimento do paciente em relação ao seu médico ou a outros profissionais da saúde, deve ser identificado um membro da equipe de saúde que seja mais acessível e com o qual o paciente se sinta mais à vontade para relatar suas dificuldades em aderir ao tratamento. Esse membro da equipe pode ser uma enfermeira, assistente social ou psicóloga, caso não seja possível estabelecer uma relação mais aberta entre o paciente e seu médico, o que seria o desejável.

DisPositivos ELETRÔNICOS: os dispositivos de monitoramento eletrônico, como o Medication Event Monitoring System (MEMS Cap), constituem uma ferramenta importante. O MEMS Cap é uma tampa de medicamento que possui um chip de computador capaz de gravar a data e o horário em que o paciente abre o vidro (frasco) que contém os medicamentos, podendo gravar até 1.800 datas e horários diferentes. O sistema é bastante útil para alguns medicamentos, mas, no contexto da HAART, apresenta alguns problemas. Muitos pacientes preferem utilizar uma caixinha de remédios com subdivisões, por exemplo, para os dias da semana, não levando consigo o frasco inteiro do medicamento (que está com a tampinha do MEMS Cap). Esse dispositivo também não é muito confiável 
para medir a aderência de pessoas que retiram mais de uma dose de remédio de dentro do frasco de cada vez, além de não funcionar quando o paciente esquece o frasco sem tampa, perde a tampa ou guarda mais de um tipo de remédio dentro do mesmo frasco. Além desses inconvenientes, o dispositivo é caro e pesado.

Contagem de Pílulas: a contagem de pílulas pode ser feita por membros da equipe durante a consulta de rotina do paciente. O processo consiste em, simplesmente, contar as pílulas existentes em cada um dos frascos de medicamentos antirretrovirais que o paciente trouxer para a consulta. As contagens não agendadas são mais confiáveis, uma vez que o paciente não pode predizê-las e com isso retirar pílulas que estejam em excesso no frasco. A utilização desse método só é possível se o paciente levar seus frascos de medicamentos para as consultas. Se um paciente estiver dividindo seus medicamentos com outro, a contagem estará errada. Mas o principal ponto negativo desse método é que a contagem de pílulas pode criar uma relação negativa entre paciente e médico, uma vez que o médico pode ser visto como alguém que está desconfiado, controlando a tomada de medicamentos do paciente, e não como alguém que está do seu lado para ajudá-lo.

MonitorAmENTO FARMACÊUTICO: a equipe responsável pela liberação de medicamentos antirretrovirais das farmácias pode ser uma importante fonte de informações sobre a aderência dos pacientes em acompanhamento. Em serviços nos quais existe um controle adequado da dispensação (fornecimento) de medicamentos, é bastante fácil avaliar quais os pacientes que estão retirando, mensalmente, seus medicamentos antirretrovirais e quais não os estão retirando com a frequência necessária. O monitoramento farmacêutico é mais confiável quando o paciente retira seus medicamentos em uma única farmácia. Apesar disso, é importante ressaltar que dados de farmácia não podem ser utilizados isoladamente como método para avaliar a aderência à HAART, pois o fato de retirar medicamentos da farmácia não equivale, necessariamente, a tomá-los de forma adequada. Os pacientes podem retirar os medicamentos em mais de uma farmácia (caso o sistema de controle permita isso), podem dividi-los com outras pessoas, podem pegá-los na farmácia, mas não utilizá-los (ou utilizá-los de modo distinto do que está prescrito), ou podem até mesmo jogá-los fora.

MARCADORES BIOLÓGiCOS: uma vez que o objetivo da HAART é reduzir a quantidade de vírus encontrada no sangue do paciente (medida através do exame denominado carga viral), o monitoramento da carga viral pode indicar a eficácia da medicação. Porém, alguns pacientes mantêm uma carga viral alta 
mesmo sendo aderentes ao esquema terapêutico que lhes foi prescrito. Problemas relativos à má-absorção do medicamento e à resistência terapêutica podem levar a uma resposta ao tratamento aquém do esperado.

Embora não exista uma relação simples entre melhora clínica e aumento do número e proporção de células de defesa (CD4+), é bastante comum que a medicação contribua para uma reconstituição do sistema imunológico do paciente, com aumento do nível de células CD4+ no sangue.

Outro marcador biológico que pode ser utilizado é a quantificação do nível de medicação existente no sangue do paciente. Porém, essa medição tem como parâmetro apenas a última dose de medicamento tomada, o que pode levar a conclusões precipitadas, que não reflitam o histórico do paciente. Além disso, as técnicas atualmente disponíveis para a medição da concentração de medicamento no sangue são caras e possuem uma utilidade limitada como medida para avaliação da aderência

ESTIMATIVA DO MÉDICO: de todas as medidas já descritas, a estimativa do profissional que atende o paciente, se não estiver apoiada em exames clínico-laboratoriais, é a que apresenta a pior correlação com a real aderência ao tratamento HAART.

\section{Organizando um programa de aderência}

Programas voltados para a aderência têm sido implementados nos mais diferentes serviços, desde organizações não governamentais (ONGs) e organizações comunitárias até grandes complexos hospitalares. Não existe um serviço ou local que possa ser considerado 'melhor' para organizar um programa voltado para a aderência aos medicamentos antirretrovirais, e o sucesso dos diferentes programas é bastante variado. Porém, alguns aspectos são bastante importantes para aumentar a aderência do paciente, independente do serviço no qual o programa de aderência esteja inserido. Dentre eles estão a privacidade, a localização do serviço, a utilização do tempo livre, a informalidade, o cuidado de crianças e a avaliação.

Os pacientes precisam sentir que podem falar sobre suas preocupações em um local seguro e com privacidade. Serviços nos quais os espaços são muito pequenos e/ou não oferecem a privacidade necessária (como, por exemplo, salas de atendimento separadas por biombos ou vazadas) podem tornar a falta de privacidade do paciente um problema. A privacidade do paciente constitui um aspecto fundamental para abordar a aderência ao tratamento, sendo mais 
facilmente alcançada em salas privativas e não compartilhadas com outros pacientes e/ou outros profissionais da saúde.

Em serviços de saúde nos quais a equipe trabalha de forma integrada e num espaço comum, dispõe-se de mais tempo e oportunidades para discutir sobre pacientes específicos ou questões mais gerais relacionadas à aderência. Profissionais já conhecidos dos pacientes e nos quais estes confiam podem introduzir com mais facilidade novos serviços de saúde e apresentar outros profissionais em uma atmosfera de maior confiança. A localização de diferentes serviços em um mesmo espaço físico (por exemplo, o atendimento para HIV/Aids, saúde mental e dependência química) facilita bastante o manejo de pacientes com necessidades múltiplas e constitui um importante fator para que se alcance uma melhor aderência do paciente ao esquema terapêutico.

A frequente frustração e/ou impaciência que muitos pacientes apresentam ao terem de esperar pelo atendimento pode ser bastante reduzida se esse tempo de espera for transformado em um momento construtivo para eles. Estratégias criativas como minipalestras organizadas na sala de espera e apresentação de vídeos, agendamentos coordenados (o paciente se consulta, no mesmo dia, com o infectologista, com o psicólogo e com o assistente social) e organização de grupos de apoio e/ou terapia ocupacional devem ser propostas e implementadas. Alguns serviços disponibilizam esses espaços, nas salas de espera, para ONGs e/ou organizações comunitárias, pois muitas vezes a equipe de saúde não dispõe do tempo necessário para organizar essas atividades adicionais.

Muitos pacientes não se sentem totalmente confortáveis no espaço do serviço de saúde, seja por não compreenderem as informações recebidas, seja em virtude da autoridade que os profissionais da saúde representam. A diminuição dos sinais de autoridade e a percepção de uma atmosfera receptiva e amigável podem ajudar a pessoa a se sentir mais à vontade nesse espaço. Por exemplo, alguns profissionais da saúde preferem não usar roupas totalmente brancas, certos serviços disponibilizam um local onde os pacientes interajam entre si e possam manter conversas informais entre pacientes e com profissionais da saúde, abordando questões relativas ao HIV/Aids, a medicamentos e a qualquer outro assunto que queiram abordar.

Por não ter com quem deixar os filhos, alguns pacientes podem encontrar dificuldades para comparecerem aos agendamentos. Alguns serviços possuem espaços onde as crianças possam ficar enquanto seus responsáveis são atendidos. Outros serviços estabelecem cooperações com ONGs para que esse cuidado de crianças não sobrecarregue as tarefas rotineiras dos profissionais 
do serviço. Nos casos em que a criança também é portadora do HIV/Aids, o cuidado dela pode ser feito em conjunto com atividades educativas e serviços de apoio para a aderência ao tratamento de toda a família (por exemplo, brinquedotecas, jogos educativos etc.).

É fundamental que os serviços de aderência sejam constantemente avaliados pela equipe de saúde, pelos pacientes e pela comunidade atendida. Essa avaliação constante permite identificar aspectos que precisam ser melhorados e áreas que precisam ser abordadas por novas ações. A avaliação geralmente fomenta a elaboração de soluções criativas para muitos serviços nos quais existe escassez de recursos e de profissionais e pouco espaço. Avaliações feitas no formato de questionário, fóruns, ou elaboradas por conselhos consultivos constituem ferramentas importantes para assegurar que as ações implementadas pelo serviço de saúde estão de acordo com as necessidades da clientela atendida.

\section{Importantes Estratégias para a Equipe de Saúde}

O HIV/Aids é uma infecção/síndrome complexa que afeta diversos aspectos da vida e da saúde das pessoas que vivem com ela. Um serviço de saúde que ofereça uma atenção integrada e multidisciplinar facilita a identificação de questões que podem influenciar a capacidade do paciente de aderir ao esquema terapêutico. Dependendo dos recursos humanos disponíveis, a equipe pode ser multidisciplinar ou não. Algumas vezes inclui apenas médicos e enfermeiras; em outros locais, pode compreender também assistentes sociais, psicólogos, agentes da saúde, nutricionistas, profissionais da área de dependência química etc.

Uma equipe de saúde diversificada pode disponibilizar um atendimento mais adequado às diversas enfermidades cujo surgimento é comum quando se trata de pacientes que são usuários de drogas vivendo com HIV/Aids, tais como comorbidades psiquiátricas, coinfecções (hepatites virais e outras infecções sexualmente transmissíveis - ISTs), necessidade de suporte social etc. Serviços que não dispõem de equipes diversificadas podem estabelecer redes de referência e contrarreferência, encaminhando pacientes para serviços mais especializados e/ou recebendo doentes encaminhados por outros serviços. O ponto principal em ambas as formas de atendimento - multidisciplinares ou não - é a comunicação entre os diferentes profissionais. 
Reuniões regulares de equipe (no caso de serviços multidisciplinares) ou o ágil contato entre profissionais de diferentes serviços responsáveis por pacientes em comum são fundamentais. Um canal de comunicação eficiente facilita o manejo de casos em conjunto e o entrosamento da equipe como um todo. Também é importante certificar-se de que o paciente não se sinta incomodado quanto ao compartilhamento de suas informações pessoais entre vários profissionais da saúde.

Problemas relacionados à quebra de sigilo e confidencialidade podem ser evitados/minimizados através de uma conversa franca com o paciente, para que ele saiba e concorde que os profissionais da saúde discutam seu caso em uma reunião de equipe, ou que profissionais de diferentes serviços façam o mesmo. As reuniões de equipe são muito importantes para a coordenação do tratamento dos pacientes e constituem uma excelente oportunidade para o compartilhamento de informações, possibilitando à equipe a utilização de uma abordagem comum diante de casos mais complexos, como o de pessoas que usam drogas vivendo com HIV/Aids.

Quadro 1 - Princípios que devem guiar a equipe de saúde

- Inclusão dos diferentes profissionais envolvidos no caso a ser discutido

- Organização de reuniões regulares para coordenar o tratamento oferecido

- Estabelecimento de canais de comunicação diretos entre os diferentes profissionais da equipe e entre os diferentes serviços de referência (ex: serviços para tratamento de dependência química, saúde mental, tratamento do HIV/Aids etc.)

\section{Relacionamento entre pacientes e profissionais da saúde}

Um importante fator de estímulo à aderência ao regime terapêutico, especialmente para doenças crônicas, é o relacionamento entre o paciente e seu médico. No caso específico de pacientes que usam (ou usaram) substâncias ilícitas, essa questão é de suma importância para facilitar sua aderência ao tratamento. Muitas vezes, pessoas que usam drogas não se sentem à vontade ou acolhidas de forma adequada nos serviços de saúde, o que pode determinar uma baixa aderência ou mesmo o abandono do tratamento por parte de uma importante parcela dessa população. O paciente pode se sentir mais à vontade com alguns profissionais da equipe do que com outros, mas deve sentir que pode confiar na equipe do serviço como um grupo integrado, falar abertamente 
sobre seus problemas e participar de forma ativa na resolução de problemas que possam surgir ao longo do seu tratamento.

Apresentamos a seguir algumas sugestões para melhorar a interação entre os profissionais e o paciente.

Fazer perguntas diretas, em tom amigável, a respeito da ingestão de medicamentos estimula uma conversa mais franca sobre questões que podem afetar a aderência ao tratamento. Uma abordagem direta permite que o paciente converse mais francamente sobre as razões que podem estar influenciando sua não aderência. O paciente e seu médico podem, então, planejar maneiras de melhorar a aderência e superar os problemas enfrentados. Atitudes de confrontação entre médico e paciente geralmente são ineficazes e podem ter um efeito contrário, levando o paciente a não se sentir à vontade para conversar abertamente sobre futuros problemas. Se o paciente perceber uma posição acusatória por parte de algum membro da equipe, com relação às suas dificuldades em aderir ao tratamento, pode parar de conversar com os profissionais da saúde ou até mesmo desistir do tratamento. Esses problemas costumam ser bastante frequentes entre pessoas que usam drogas vivendo com HIV/Aids.

Deve-se disponibilizar oportunidades para que os pacientes discutam sobre a aderência com diferentes profissionais da equipe de saúde. Os pacientes podem se sentir mais à vontade para conversarem sobre questões ligadas à aderência com mais de um membro da equipe, e alguns pacientes podem relatar, para dois profissionais diferentes, informações conflitantes. Essa abordagem pode ajudar a equipe a compreender de forma mais fidedigna e abrangente o que realmente está acontecendo com o paciente em questão.

Estimular o paciente a dar retorno (feedback) constitui uma estratégia fundamental para buscar uma maior adequação aos seus problemas, sugerindo mudanças comportamentais ou adotando estratégias de comunicação adequadas aos problemas relatados. Ao escutar, de forma atenta, as dificuldades e dúvidas de cada paciente, a equipe tem a oportunidade de elaborar estratégias mais adequadas às diferentes populações atendidas.

\section{Intervenções ligadas à informação e educação}

As intervenções educativas constituem ferramentas fundamentais para a promoção e manutenção da aderência ao tratamento. Algumas estratégias educativas serão vistas a seguir. 
As informações escritas sobre HIV, HAART, uso de substâncias psicoativas/ álcool e saúde em geral (folhetos, revistas etc.) devem estar disponíveis nas salas de espera e devem ser distribuídas pela equipe de saúde.

A assinatura de revistas ou jornais que apresentem histórias pessoais e que incluam dicas e sugestões de como lidar com os efeitos colaterais e aderência também pode ser considerada uma ação educativa. A publicação de artigos escritos por pacientes pode funcionar como uma válvula de escape, aliviando o sentimento de isolamento de muitos pacientes. Essas dicas são ainda mais eficazes quando elaboradas por pacientes e educadores por pares, ao invés de sugestões elaboradas exclusivamente pela equipe de saúde.

Outra boa intervenção educativa é a frequente distribuição de kits educativos individuais que podem ser gerados por computador, especificamente elaborados para um determinado paciente, ou organizados a partir de materiais educativos diferentes, que abordem os problemas que esse paciente específico está enfrentando. A entrega de um kit educativo pode representar uma ferramenta auxiliar importante, pois o paciente passará a dispor de materiais para rever e consultar em casa, e mesmo para que seus familiares ou responsáveis possam estar mais informados sobre a doença e as formas de lidar com possíveis problemas.

A existência de aparelhos de vídeo disponíveis na sala de espera e em grupos de discussão ou de materiais audiovisuais que os pacientes possam levar para casa constitui outra forma de educação e multiplicação de informações importantes. Alguns serviços optam por oferecer sessões de vídeos em ONGs ou em organizações comunitárias, realizando em seguida um debate com representantes da comunidade e dos serviços de saúde.

Embora não pareça, outra intervenção educativa de bastante importância refere-se à disponibilidade frequente de agentes de saúde ou de outros profissionais da equipe para atenderem as perguntas e darem informações tanto sobre questões mais gerais relativas à saúde quanto sobre questões especificamente relacionadas ao HIV/Aids e à HAART.

Uma estratégia importante é reforçar, a cada consulta, a importância de não ficar sem remédios e agendar com antecedência a data para que o paciente venha buscar seus medicamentos. Ações educativas expressas em linguagem acessível e adequada, que abordem a importância de não interromper a terapia, devem ser implementadas. Deve ser elaborado um esquema de controle do estoque de farmácia, para que os médicos responsáveis possam acompanhar quais os pacientes que estão retornando à farmácia com a frequência 
necessária e em relação a quais pacientes é imprescindível oferecer informações mais detalhadas sobre essa questão.

Outra ferramenta educativa é a existência ou a formação de grupos de pacientes, cuidadores (pessoas responsáveis pelos pacientes, como companheiros/as, pais etc.) e profissionais da saúde. Esses grupos podem tratar de assuntos específicos, escolhidos pelos pacientes, organizar palestras, debates com mais de um profissional da saúde enfocando um mesmo tema (por exemplo, abordar a importância da adesão ao tratamento, do ponto de vista de um infectologista, de um psicólogo e de um farmacêutico) etc.

Uma medida instrutiva que também pode ter efeito surpreendente é a organização de sessões educativas sobre como tirar o máximo proveito das consultas médicas, incluindo dicas para melhorar a comunicação entre paciente e médico e atividades práticas de simulação de consultas. Muitos pacientes podem ter pouca experiência com serviços de saúde, ou achá-los confusos, intimidantes e/ou pouco amigáveis, por isso é importante apresentar os diferentes serviços de saúde disponíveis, a forma como esses atendimentos funcionam, como o paciente deve agendar suas consultas, a quem pode procurar em caso de emergências, dúvidas etc. Apresentações dessa natureza podem facilitar a aderência do paciente ao tratamento, melhorar sua comunicação com a equipe de saúde e facilitar seu acesso aos diferentes níveis e modalidades de atendimentos disponíveis. Essas informações podem ser disponibilizadas em uma reunião mensal com novos pacientes e/ou podem estar disponíveis em um pequeno folheto, que contenha dias e horários dos diferentes atendimentos, serviços de referência, telefones úteis etc.

Sempre que possível, a equipe de saúde deve ter acesso a publicações atualizadas sobre HIV/Aids e áreas afins e a treinamentos periódicos relacionados às suas áreas de concentração. Uma equipe bem treinada e atualizada oferece melhor atendimento e mostra-se apta a lidar com problemas que costumam influenciar a aderência a antirretrovirais.

Ao se elaborar intervenções educativas, é necessário levar em conta as características da população atendida no serviço, sobretudo com relação ao nível de escolaridade, grau de analfabetismo/analfabetismo funcional dos pacientes atendidos. Os materiais educativos devem ser elaborados com linguagem adequada à população atendida. Serviços que atendam uma população muito diversa em termos de escolaridade podem optar por disponibilizar materiais diferenciados e adequados aos diversos níveis de compreensão e escolaridade dos pacientes atendidos. Para pacientes com dificuldades de leitura, é indispensável a elaboração de materiais educativos com figuras e ilustrações. 


\section{Prevenindo faltas em consultas agendadas}

Faltas a consultas pré-agendadas podem constituir uma grande barreira à aderência, tanto para o tratamento para a dependência química quanto para a infecção pelo HIV. Faltar a uma consulta agendada pode ser um sinal de redução na motivação do paciente em aderir ao tratamento, de uma recaída no consumo abusivo de álcool/drogas ou de problemas pessoais os mais diversos (não ter com quem deixar os filhos, não ter dinheiro para transporte etc.).

Qualquer que seja o motivo para faltar à consulta, essa ausência também pode representar a necessidade de estimular ou reforçar um diálogo franco entre paciente e médico sobre a importância da aderência aos tratamentos e da abordagem dos problemas que a pessoa possa estar enfrentando para alcançar a aderência necessária. É importante que a equipe elabore estratégias para minimizar o número de faltas a consultas pré-agendadas. Além disso, é necessário que o paciente saiba que é sempre bem-vindo ao serviço e que sua presença é extremamente importante, mesmo que para isso seja preciso encaixar sua consulta sem marcação prévia.

Existem algumas estratégias utilizadas para minimizar as ausências às consultas. O one-stop shopping (agendamento integrado) é uma estratégia que facilita bastante a aderência do paciente. Trata-se de organizar agendamentos integrados, ou seja, em uma única ida ao serviço de saúde, o paciente se consulta com os diferentes profissionais envolvidos em seu atendimento (por exemplo: após a consulta com o infectologista, o paciente conversa com a enfermeira, recebe materiais educativos e preservativos, recebe seus medicamentos e depois participa do atendimento individual para manejo de sua dependência química ou do grupo de aderência ao tratamento com a equipe de saúde mental). A chance de que o paciente esteja presente ao longo de um único dia para todos os atendimentos é substancialmente maior do que a chance de ele comparecer em dias sucessivos, cada dia para um atendimento diferente. Uma única viagem ao serviço de saúde reduz o tempo de espera dos pacientes, facilita seus agendamentos, evita que percam vários dias de trabalho, gastem mais dinheiro com passagem e/ou enfrentem barreiras relativas ao cuidado de seus filhos.

A flexibilidade nos horários de atendimento também é uma estratégia importante. Alguns pacientes podem encontrar maior dificuldade para aderir a agendamentos em determinados horários ou dias específicos da semana (por exemplo, pessoas que usam drogas ou profissionais do sexo geralmente encontram maior dificuldade em comparecer a agendamentos pela manhã; pacientes 
que trabalham em horário integral podem se beneficiar de agendamentos no final do dia). Sempre que possível, é importante oferecer uma variedade de agendamentos, inclusive à tarde e nos fins de semana. A disponibilização de consultas não agendadas também aumenta a acessibilidade dos pacientes ao serviço, o que é particularmente importante quando estes precisam esclarecer dúvidas ou relatar preocupações imediatas (por exemplo, o que fazer diante de determinado efeito colateral, qual o alimento a ser tomado junto com o medicamento etc.).

Alguns serviços buscam formas de lembrar ao paciente acerca de sua consulta (por meio de telefonemas, telegramas etc.), estratégias especialmente relevantes quando se trata de pacientes com histórico de baixa frequência aos agendamentos. Porém, é preciso ter sempre em mente a questão da confidencialidade ao entrar em contato com um paciente vivendo com HIV/Aids. É importante conversar com ele e identificar qual a melhor forma de contactá-lo entre as consultas.

Os calendários individualizados podem ser utilizados como lembretes tanto das consultas como dos medicamentos (horários, formas de tomar etc.) e a existência de uma equipe responsável pelo agendamento é essencial, principalmente se ela for devidamente treinada para evitar agendamentos em datas ou horários inadequados para os pacientes. Perguntas claras e em tom amigável devem ser elaboradas pela equipe de saúde para evitar esses problemas.

A identificação das razões pelas quais um paciente está faltando a seus agendamentos, sobretudo se esse fato tem-se tornado uma constante, evidencia, muitas vezes, barreiras que podem vir a ser superadas. Existem muitas barreiras para as quais o serviço pode oferecer assistência (por exemplo, se o paciente não tem dinheiro para o transporte, pode ser encaminhado para a triagem do serviço social e pode ser indicado para auxílio governamental). É importante dispor de mais de uma forma para contatar pacientes faltosos (telefone, endereço residencial, vizinhos etc.).

O apoio de serviços externos pode facilitar a aderência a consultas agendadas. Esse tipo de serviço pode contar com a participação de agentes de saúde (PSF), representantes de ONGs, organizações comunitárias locais e projetos/ estratégias como a educação entre pares (como outros pacientes e amigos às voltas com dificuldades similares).

No manejo de usuários de drogas vivendo com HIV/Aids, é fundamental que a equipe de saúde seja flexível e esteja aberta a debater as questões que se apresentam, pois ao longo do tratamento o paciente pode se deparar com efei- 
tos colaterais dos medicamentos, infecções oportunistas, problemas emocionais, pessoais, recaídas no consumo de álcool e drogas etc. Esses problemas podem ocorrer entre consultas previamente agendadas e influenciar a capacidade do paciente em aderir adequadamente ao tratamento prescrito. No âmbito dos portadores de HIV/Aids, o abandono do tratamento ou a decisão de tirar 'férias' dos medicamentos durante um período podem resultar em problemas sérios, como o desenvolvimento de cepas virais multirresistentes e a consequente falha terapêutica. O acesso facilitado à equipe de saúde pode evitar que dúvidas ou dificuldades cotidianas possam vir a comprometer a qualidade de vida desse paciente.

\section{Conclusão}

O presente trabalho se insere em um esforço global que objetiva aumentar o acesso de populações em situação de vulnerabilidade acrescida à HAART. Essa estratégia global foi lançada pela Organização Mundial da Saúde (OMS), no ano de 2003, inicialmente através da iniciativa " 3 by 5". Atualmente existe a estratégia "Treatment 2.0", que engloba um conjunto de ações amplas que objetivam simplificar os esquemas terapêuticos disponíveis, ampliar o acesso ao tratamento para HIV/Aids, aproximar a oferta de tratamentos para HIV/Aids, saúde sexual e reprodutiva, além de propor diversas formas de treinamento de profissionais de saúde.

De acordo com os relatórios anuais da Unaids/WHO sobre a epidemia de HIV/Aids, existem aproximadamente 5,2 milhões de pessoas vivendo com HIV/ Aids recebendo tratamento no momento de elaboração desse texto (setembro de 2011). No entanto, mais de 10 milhões de pessoas que precisam receber tratamento para HIV/Aids ainda não têm acesso ao tratamento necessário (Unaids/ WHO, 2011). ${ }^{1}$

Embora o acesso ao tratamento tenha se ampliado consideravelmente nos últimos anos - em 2004, apenas 400.000 pessoas recebiam o tratamento -, o acesso à HAART ainda permanece bastante desigual para a maioria das pessoas que usam drogas ilícitas ao redor do mundo. Em muitos países, os usuários de drogas são inelegíveis para receber tratamento, a não ser que estejam engajados em algum tratamento para abstinência durante determinado período de tempo. Com isso, a mortalidade e a morbidade entre usuários de drogas que vivem

1 Informações constantemente atualizadas e disponíveis no site </www.unaids.org $>$. 
com HIV/Aids atingem patamares ainda bastante elevados em diversas partes do mundo (Unaids/WHO, 2011).

Além dessa clara situação de iniquidade, o acesso a antirretrovirais envolve muito mais do que apenas a simples distribuição de medicamentos, sobretudo para populações especialmente vulneráveis e que necessitam de intervenções complexas, como usuários de drogas vivendo com HIV/Aids. Uma grande dificuldade enfrentada por essa população é a escassez ou mesmo a inexistência de serviços com infraestrutura e equipes suficientes e adequadamente treinadas para atender às suas necessidades específicas.

$\mathrm{Na}$ América Latina, em geral, a integração atualmente existente entre serviços para o tratamento de HIV/Aids, dependência química e saúde mental está longe do ideal e precisa ser substancialmente reforçada. Para melhorar essa dificuldade de integração, têm sido formuladas diversas estratégias, organizadas, sobretudo, por meio de parcerias entre organizações internacionais, como a Opas e a OMS, e governos locais. Essas parcerias são fundamentais para a organização de agendas e ações prioritárias e para a disponibilização de recursos que objetivem melhorar a capacitação de profissionais e a qualidade dos serviços hoje disponíveis para usuários de drogas vivendo com HIV/Aids.

O estabelecimento de colaborações internacionais entre os diversos países da América Latina é extremamente importante, pois possibilita a divulgação e a multiplicação de melhores práticas na área da saúde. Parcerias internacionais, estabelecidas com base em uma agenda acordada em comum, facilitam o compartilhamento de experiências, conhecimentos e tecnologias na busca de uma melhor qualidade de serviços e ações em saúde pública.

O presente texto se insere no âmbito dessas parcerias, pois objetiva disponibilizar informações úteis para os diversos serviços que atendem usuários de drogas vivendo com HIV/Aids, além de contribuir para o embasamento de iniciativas locais de treinamento e capacitação para diferentes profissionais que atendem essa população. Outro objetivo importante é servir como uma ferramenta para que diferentes profissionais da saúde, serviços de saúde diversos e organizações comunitárias possam trabalhar em conjunto. Pretende-se, com isso, estimular que diferentes atores possam unir esforços para possibilitar aos usuários de drogas vivendo com HIV/Aids uma forma mais eficaz de acesso e engajamento nos serviços de assistência e tratamento.

A epidemia de HIV e Aids não conhece fronteiras geográficas ou de qualquer natureza, nem tampouco pode ser enfrentada eficazmente de forma isolada. Portanto, os esforços cooperativos representam uma importante estratégia para 
elaborar planos de ações e definir agendas em comum, fortalecer estratégias nacionais e internacionais e multiplicar melhores práticas entre países vizinhos.

Como demonstra a ampla literatura internacional, epidemias locais de HIV e Aids só podem ser enfrentadas mediante o trabalho conjunto desenvolvido por formuladores de políticas, serviços de saúde, organismos governamentais e não governamentais, organizações comunitárias e representantes das populações afetadas. É, portanto, fundamental o estabelecimento de parcerias para o enfrentamento mais eficaz dessa epidemia.

O desafio de aumentar o acesso à HAART e a qualidade dos serviços disponíveis para usuários de drogas vivendo com HIV/Aids não poderá ser superado por um único serviço. É necessário, para tal, o estabelecimento e a manutenção de uma ampla gama de parcerias, além de ser importante a coordenação dos esforços e das ações desenvolvidas para preencher lacunas, sem duplicar esforços desnecessariamente.

Ao longo de quase três décadas do surgimento da epidemia de HIV no Brasil, muito foi alcançado através do trabalho conjunto de profissionais, ativistas, formuladores de políticas, representantes da sociedade civil e redes de agências nacionais e internacionais. Porém, muito ainda está por ser feito, sobretudo por se tratar de um país com dimensões continentais, no qual as desigualdades sociais e econômicas, o estigma e o preconceito dirigido às comunidades mais vulneráveis e minorias diversas ainda atingem níveis inaceitáveis. Tais problemas muitas vezes acabam influenciando o acesso de populações vulneráveis a ações preventivas e assistenciais, como é o caso dos usuários de drogas e profissionais do sexo.

Como parte de iniciativas mais globais, voltadas tanto para a prevenção quanto para a assistência a portadores do HIV/Aids em populações vulneráveis - particularmente usuários de drogas -, é necessário estimular a elaboração de intervenções culturalmente adequadas e que tenham continuidade ao longo do tempo. Para isso, é indispensável a elaboração de estratégias que permitam uma interlocução mais próxima entre formuladores de políticas, agências financiadoras, serviços de saúde e de apoio social, organizações não governamentais e usuários de drogas. Apenas mediante essa parceria e a constante avaliação e reavaliação das ações disponíveis será possível estruturar respostas mais adequadas e sustentáveis ao longo do tempo.

À medida que o país aprimore suas estratégias voltadas para a redução da vulnerabilidade de usuários de drogas frente ao HIV e à Aids e às demais ISTs, estaremos no caminho de uma maior inclusão social, possibilitando uma melhor 
qualidade de vida a uma população que, historicamente, tem estado à margem das intervenções em saúde. Esse movimento de inclusão vai ao encontro de uma premissa básica em saúde pública, que é a prevenção de danos à saúde, e atende aos direitos assegurados pela Constituição brasileira de cidadania e demais diretrizes do SUS relativas à universalidade, equidade e integralidade.

\section{Referências}

AGINS, B. et al. Substance abuse treatment should be key component of HIV treatment plan. Experts explain some best-practice strategies. Aids Alert, 16(7):81-83, 2001.

BAMBERGER, J. D. et al. Helping the urban poor stay with antirretroviral HIV drug therapy. American Journal Public Health, 90:699-701, 2000.

BROADHEAD, R. S. et al. Increasing drug users' adherence to HIV treatment: results of a peer-driven intervention feasibility study. Social Science \& Medicine, 55(2): 235-246, 2002.

CLARKE, S. et al. Directly observed antirretroviral therapy for injection drug users with HIV infection. Aids Read, 12(7): 305-307; 312-316, 2002.

CUNNINGHAM, W. E. et al. The association of health-related quality of life with survival among persons with HIV infection in the United States. Journal of General Internal Medicine, 20(1):21-27, 2005.

INCIARDI, J. A. \& SURRATT, H. L. Drug use, street crime, and sex-trading among cocaine-dependent women: implications for public health and criminal justice policy. Journal of Psychoactive Drugs, 33(4):379-389, 2001.

JAFFAR, S. et al. Antiretroviral treatment in resource-poor settings: public health research priorities. Tropical Medicine and International Health, 10(4): 295-299, 2005.

JOINT UNITED NATIONS PROGRAMME ON HIV-AIDS/WORLD HEALTH ORGANIZATION (UNAIDS/WHO). Disponível em:<www.unaids.org/en/>. Acesso em: 29 set. 2011.

KALICHMAN, S. C. et al. Perceptions of health care among persons living with HIV/ Aids who are not receiving antiretroviral medications. Aids Patient Care STDS, 16(5): 233-240, 2002.

KNOWLTON, A. R. et al. Access to medical care and service utilization among injection drug users with HIV/Aids. Drug and Alcohol Dependence, 64(1): 55-62, 2001.

LATKIN, C. A.; KNOWLTON, A. R. \& SHERMAN, S. Routes of drug administration, differential affiliation, and lifestyle stability among cocaine and opiate users: implications to HIV prevention. Journal of Substance Abuse, 13(1-2): 89-102, 2001. 
MARTIN, J. et al. Outcomes of a health education intervention in a sample of patients infected by HIV, most of them injection drug users: possibilities and limitations. Aids Care, 13(4): 467-473, 2001.

MOATTI, J. P.; SPIRE, B. \& KAZATCHKINE, M. Drug resistance and adherence to HIV/Aids antiretroviral treatment: against a double standard between the north and the south. Aids, 18(Suppl 3): S55-61, 2004.

ORRELL, C. Antiretroviral adherence in a resource-poor setting. Current HIV/Aids Reports, 2(4): 171-176, 2005.

PECHANSKY, F et al. HIV seroprevalence among drug users: an analysis of selected variables based on 10 years of data collection in Porto Alegre, Brazil. Drug and Alcohol Dependence, 82(Suppl 1):S109-113, 2006.

REMIEN, R. H. et al. Universal access to antiretroviral therapy may be the best approach to 'Do no harm' in developing countries: the Brazilian experience. Aids, 17(5): 786-787, 2003.

SANTIBANEZ, S. S. et al. Update and overview of practical epidemiologic aspects of HIV/Aids among injection drug users in the United States. Journal of Urban Health, 83(1): 86-100, 2006.

STVILIA, K. et al. Prevalence of hepatitis C, HIV, and risk behaviors for blood-borne infections: a population-based survey of the adult population of T'bilisi, Republic of Georgia. Journal of Urban Health, 83(2): 289-298, 2006.

SURRATT, H. L. Indigence, marginalization and HIV infection among Brazilian cocaine users. Drug and Alcohol Dependence, 58(3): 267-274, 2000.

VLAHOV, D. \& CELENTANO, D. D. Access to highly active antiretroviral therapy for injection drug users: adherence, resistance, and death. Cadernos de Saúde Pública, 22(4): 705-178, 2006. 


\section{8 \\ 13 \\ Relativismo Cultural e Uso de Álcool: contribuições a partir do campo da saúde indígena'

\author{
Maximiliano Loiola Ponte de Souza \\ Luíza Garnelo
}

\section{Da Amazônia Indígena aos Serviços de Saúde}

A reversão do modelo hospitalocêntrico para um modelo de atenção à saúde de base comunitária configura-se num desafio teórico-conceitual e prático. Garnelo e Langdon (2005) destacam que equipes do Programa Saúde da Família (PSF), desenvolvendo ações básicas de saúde em domicílios e comunidades, deixam de contar com a moldura protetora dos serviços que circunscrevem e modelam as relações terapêuticas e passam a trabalhar em territórios regidos por lógicas próprias, desconhecidas para os profissionais, que raramente dispõem de um arsenal teórico para lidar com essas questões. Nessas circunstâncias, tendem a guiar suas ações segundo suas habilidades pessoais, experiências prévias e o senso comum. Por sua vez, os recursos pessoais mobilizados pelos sujeitos são fortemente influenciados pela formação profissional, que, "fundada no biologismo e no individualismo, não os habilita a distinguir uma idiossincrasia individual de um padrão grupal de

\footnotetext{
Os autores agradecem o apoio do Ministério de Ciência e Tecnologia-Conselho Nacional de Pesquisa/Ministério da Saúde - Secretaria de Ciência, Tecnologia e Insumos Estratégicos-Departamento de Ciência e Tecnologia (MCT-CNPq/MS-SCTIE-DECIT), Edital n. 38/2005, processo n. 400904/2005-5.
} 
comportamento, forjado a partir de produções culturais específicas" (Garnelo \& Langdon, 2005: 141).

Se tal fato configura um importante obstáculo a ser enfrentado pelos profissionais que atuam na atenção básica, o desafio ainda maior será para as equipes que atuarão (ou já atuam) em saúde mental, em serviços de base comunitária, desenvolvendo atividades de tratamento, recuperação, prevenção e promoção da saúde na área do uso de álcool. Nesse campo de atuação, é fundamental tanto reconhecer e incorporar às práticas sanitárias a variabilidade dos modos de beber, em diferentes contextos socioculturais e históricos, quanto compreender que a identificação de padrões anormais de consumo de álcool deveria passar pelo entendimento do que seria, em determinada situação social, o modo considerado adequado de beber (Menendez, 1982; Edwards, 1999). Trata-se, em suma, de reconhecer a diversidade sociocultural que cerca o uso de álcool, cujo caráter - aceitável ou reprovável - varia em função da história e da organização de cada sociedade.

Aqui, busca-se contribuir para a expansão do repertório teórico de profissionais da saúde que atuam com a temática do uso de álcool, mediante a apresentação, discussão e problematização dos conceitos de 'dependência ao álcool', 'problemas relacionados ao uso do álcool' e 'alcoolização', que vêm sendo incorporados, diferenciados e articulados pelos autores em suas pesquisas com populações indígenas do Alto Rio Negro, no noroeste da Amazônia brasileira.

Estruturar uma discussão conceitual a partir de dados de pesquisa sobre o uso de álcool por populações indígenas é o propósito central deste texto, que tem por objetivo demonstrar a importância do contexto sociocultural - não apenas como um elemento externo, mas também como uma categoria estruturante do cuidado - quando se analisam os modos de beber. Tomar uma realidade específica - reconhecida e explicitada como diferente da nossa - como ponto de condução da argumentação permite evidenciar, com clareza, a relatividade e a especificidade de diversos conceitos utilizados rotineiramente no campo da saúde mental, que serão problematizados ao longo do texto.

Colocadas as questões iniciais, convidaremos o leitor a "estranhar"2 tanto as práticas sanitárias da atenção ao uso de álcool desenvolvidas em comunidades, e não nos hospitais ou nos serviços especializados, quanto os comunitáriospotencialmente-usuários, que aqui passarão a ser considerados 'nativos'.

2 O chamado "estranhamento antropológico" é o exercício de buscar transformar aquilo que lhe é familiar em exótico, diferente, ou inusitado. Trata-se de um passo imprescindível para a realização, a contento, de uma pesquisa antropológica (Peirano, 1995). 
Para alcançar os objetivos propostos, inicialmente abordaremos o conceito de cultura, tendo em vista que se trata de um elemento teórico essencial à discussão aqui proposta e que não deve ser tomado apenas com base nas ideias do senso comum. A seguir, apresentaremos o caso clínico de um paciente indígena, do município de São Gabriel da Cachoeira (SGC), no Alto Rio Negro, residente em área urbana, que buscou um serviço especializado de saúde mental em virtude de problemas relacionados a seu modo de beber (Souza, 2005). $\mathrm{Na}$ sequência, serão correlacionadas as características do beber desse paciente com dados obtidos com base em pesquisas socioantropológicas sobre o uso de álcool, realizadas junto a populações indígenas aldeadas, em terras indígenas da região do Alto Rio Negro (Souza, 2004; Souza \& Garnelo, 2006, 2007; Souza, Schweickardt \& Garnelo, 2007). Tal comparação pretende evidenciar a importância do contexto sociocultural quando se avaliam os modos de beber.

Ao final, realizaremos um exercício de "generalização conceitual" (Deslandes \& Assis, 2002: 205), que seria aquela que, partindo de análises concebidas com base em pesquisas qualitativas conduzidas em contextos específicos, busca transpor, no campo teórico, esses achados para cenários empíricos diversos. No caso específico deste capítulo, apresentaremos possíveis contribuições dos aspectos teórico-conceituais, discutidos a partir de pesquisas realizadas com populações indígenas rionegrinas, para que sejam repensadas as práticas sanitárias e os cuidados ofertados ao usuário de álcool e drogas nos serviços de saúde mental. Pretendemos, assim, fomentar a integração de diferentes saberes, reconhecendo as especificidades socioculturais dos contextos em que se inserem usuários e prestadores de serviços e os grupos sociais com os quais interagem.

\section{Cultura e Diversidade}

Estima-se que, no Brasil, habitem entre 350 e 700 mil indígenas, pertencentes a 215 etnias e falantes de 180 línguas diferentes, correspondendo a, aproximadamente, 0,5\% da população nacional (Funai, 2008; Pagliaro, Azevedo \& Santos, 2005). Mesmo pequeno, esse contingente populacional abriga uma ampla diversidade social e cultural, cuja variabilidade nem sempre é compreendida pela sociedade brasileira.

Além das nuances determinadas pela tradição de cada grupo indígena, o cenário torna-se ainda mais complexo em virtude dos diversos modos e momentos 
assumidos pelo processo colonizatório. Autores como Lima e Pozzobon (2005) ${ }^{3}$ oferecem um vislumbre da complexidade socioambiental amazônica, na qual se destacam os grupos indígenas, distinguindo nove formas de ocupação humana na região. Nesse contexto, é importante ressaltar a presença de grupos com pouco ou nenhum contato com a sociedade envolvente ao lado de outros que vivem em relativa autonomia em terras indígenas, ou de outros que residem em condições precárias em acampamentos à beira das estradas, ou dos que se instalaram no ambiente urbano (Garnelo, Macedo \& Brandão, 2003; Gomes, 2002; Coimbra \& Santos, 2000). Mais recentemente, observa-se, particularmente no nordeste brasileiro, um amplo movimento de reetnização de grupos que, após séculos de uma pretensa assimilação às camadas mais excluídas da população rural do país, passaram a reivindicar sua identidade indígena (Oliveira, 1998).

Um cenário com tal variedade demanda muita cautela ante qualquer tentativa de generalizar achados ou pontos de vista sobre a população indígena no Brasil. Mais especificamente, o tratamento da questão do uso de bebidas alcoólicas exige, ainda, maior atenção para a diversidade cultural e histórica dos grupos indígenas, pois como ressalva Langdon,

a maneira de beber, como beber e quanto beber nas culturas indígenas tem sido definida pela etnia específica, e (...) o consumo de bebidas fermentadas é uma manifestação das atividades constitutivas para o grupo social, expressando sensações e valores particulares. Porém, para muitos desses grupos, as tradições de beber mudaram, (...) influenciadas pela introdução das bebidas destiladas, o processo de pacificação e a inserção na sociedade nacional. (Langdon, 2001: 86)

A autora nos incita a atentar para o caráter dinâmico da cultura, que se transforma, incorpora e ressignifica valores, conceitos e práticas. Assim, o conceito de cultura não pode se limitar a um conjunto de traços, comportamentos ou instituições imutáveis que caracterizariam determinado grupo. Este último conceito além de ser teoricamente anacrônico fornece as bases de sustentação

\footnotetext{
3 Estes autores tomam a categoria "produtor rural" como eixo condutor para distinguir nove tipos populacionais/econômicos que ocupam a Amazônia: povos indígenas de comércio esporádico, povos indígenas de comércio recorrente, povos indígenas dependentes da produção mercantil, pequenos produtores tradicionais, latifundiários tradicionais, latifundiários recentes, migrantes em região de fronteira, trabalhadores de grandes projetos econômicos e exploradores itinerantes (Lima \& Pozzobon, 2005).
} 
para categorias analíticas como a 'aculturação', que traz implícita a ideia de perda cultural, incongruente com a concepção dinâmica de cultura aqui adotada.

Uma das mais conhecidas definições de cultura foi formulada por Geertz (1989), que a descreve como uma teia de significados tecida pelo próprio homem. Isso implica a reafirmação do caráter mutável e heterogêneo da cultura que, em constante construção, forneceria uma diversidade de opções possíveis àqueles que a partilham. Tal forma de compreensão da cultura a representa como um fluxo de contínua reelaboração e reinvenção frente aos acontecimentos e ao andar da história.

Para a temática do uso de álcool, em particular por populações indígenas, esse conceito mostra-se relevante, pois permite reconhecer o uso de bebidas alcoólicas como parte integrante da cultura dos indígenas e, simultaneamente, conceber que a relação com o álcool pode estar sendo reelaborada em face das novas demandas trazidas pelo contato interétnico, conforme propôs Langdon (2001).

\section{Da Aldeia para a Cidade: estudo de caso}

Paciente do sexo masculino, 58 anos, casado, da família linguística tukano oriental, membro de um $s i b^{4}$ de alto status, residente há trinta anos na cidade de São Gabriel da Cachoeira (SGC); veio para avaliação da capacidade laborativa, após seis meses de licença médica em virtude de faltas ao trabalho decorrentes do uso de álcool.

Iniciou o uso de caxiri ${ }^{5}$ fraco aos 4 anos. Aos 11, foi estudar em um internato, não passando pelo ritual de iniciação masculina. ${ }^{6}$ Após a quinta série,

\footnotetext{
4 A família linguística tukano oriental abriga 15 diferentes etnias. Cada um desses grupos é subdividido em sibs, que são famílias consanguíneas, nomeadas e hierarquizadas de acordo com a ordem de nascimento de seus ancestrais fundadores. Na mitologia dos Tukano Oriental, os grupos de alto status seriam descendentes dos primeiros seres humanos que teriam emergido do mundo pré-humano, saindo da cabeça de uma "cobra-canoa", em cujo interior teria sido gestada a humanidade (Jackson, 1983).

5 Bebida alcoólica fermentada, à base de mandioca e frutas, usada em festas e rituais, cuja preparação, uma atividade exclusivamente feminina, demora pelo menos dois dias (Jackson, 1983).

6 Os internatos foram introduzidos no Alto Rio Negro por missionários católicos (salesianos), a partir da segunda década do século passado. Faziam parte de um projeto assimilacionista, civilizador e catequético, direcionado aos indígenas da região. Os missionários utilizaram a internação como uma estratégia de afastar os mais jovens da influência dos mais velhos,
} 
iniciou um curso de carpintaria que durou três anos. Posteriormente, foi para Manaus, onde permaneceu por dois anos estudando num seminário religioso. Não concluiu a formação sacerdotal. Durante o período em que esteve nos internatos, não fazia uso de álcool. Após a morte do pai e a ida dos irmãos mais velhos para os seringais na Colômbia, retornou à sua comunidade para assumir o provento da família. Em seguida, foi trabalhar em um centro missionário como instrutor de carpintaria e lá se casou. Nesse local, aos 22 anos, tomou cachaça pela primeira vez, oferecida por um comerciante como pagamento pela ajuda na travessia de um barco nas cachoeiras próximas. Esse comerciante passou a navegar regularmente pela região, sempre pagando os serviços dos indígenas com cachaça.

Dois anos depois, os irmãos voltaram da Colômbia e o paciente retornou para sua comunidade, assumindo o posto de catequista. Nesse cargo, desentendeu-se com seu irmão, que havia assumido a chefia da comunidade; ativista religioso, o paciente repreendeu o irmão por não comparecer às cerimônias religiosas. Numa festa, após o consumo de caxiri, seu irmão tentou matá-lo, o que ocasionou sua fuga da comunidade. No início da década de 1970, migrou, sem a família, para SGC, em busca de trabalho nas empresas que começavam a se instalar ali.

Morando na zona urbana, passou a beber cachaça aos sábados e domingos com outros trabalhadores. Nessas ocasiões, consumia, em média, dois litros da bebida. Nega que, nessa época, tivesse algum tipo de problema relacionado ao álcool. Após trazer sua família para a cidade, a empresa em que trabalhava deixou o lugar. Depois disso, passou a trabalhar num órgão público, no qual permanece há 22 anos. Desde essa época passou a fazer uso diário de cachaça após o trabalho. A filha do paciente refere que, após algum tempo, o pai começou a ficar violento e agressivo com os filhos e a esposa.

Nos últimos dois anos antes do atendimento, o paciente passou a faltar ao trabalho em virtude do consumo de álcool. Esbanjava muito dinheiro com bebida, chegando a gastar todo o seu salário em um único dia. Quando interrompia o consumo, apresentava sintomas de abstinência como tremores, ansiedade e alucinações visuais. Não conseguia ajudar sua esposa nos trabalhos da roça, pois no caminho encontrava amigos e já começava a beber. Constantemente

minando a autoridade destes últimos, dificultando a participação dos alunos nos rituais de iniciação masculina e comprometendo a integridade dos costumes ancestrais ali vigentes (Lasmar, 2005). Durante o período preparatório do ritual, o iniciando aprendia de forma intensiva os mitos, valores e regras de convivência social. Ao seu término, deixava de ser considerado criança e passava a integrar o grupo de homens iniciados (Hugh-Jones, 1979). 
alcoolizado, o paciente apresentava discurso delirante, referindo que suas filhas tinham sido estupradas e que estava sendo perseguido por militares e garimpeiros. Por conta das faltas ao trabalho, foi afastado de suas atividades por seis meses. Após esse período, veio para avaliação psiquiátrica de sua capacidade laboral, com vistas ao retorno ao trabalho.

\section{Dependência ao Álcool: um conceito biomédico}

De acordo com décima edição do Código Internacional de Doenças (CID-10), a síndrome de dependência seria definida como

um conjunto de fenômenos fisiológicos, comportamentais e cognitivos, no qual o uso de uma substância (...) alcança uma prioridade muito maior para um determinado indivíduo do que outros comportamentos que tinham maior valor. Uma característica descritiva central da síndrome de dependência é o desejo (frequentemente forte, algumas vezes irresistível) de consumir drogas psicoativas (...), álcool ou tabaco. (OMS, 1993: 74)

A acepção desse conceito está claramente assentada no campo biomédico. Sua ampla aceitação acadêmica relaciona-se, por um lado, à robusta contribuição científica de Griffith Edwards (Edwards et al., 1999), que influencia os atuais códigos de classificação de doenças, bem como relaciona-se às já clássicas evidências que sugerem uma etiologia biológica para a dependência ao álcool (Messas \& Vallada Filho, 2004). Por outro lado, a popularização do conceito de alcoolismo-doença está relacionada à atuação dos grupos Alcoólicos Anônimos (A.A.), que explicitamente o adotam.

No caso descrito, guiando-nos pelo CID-10 (OMS, 1993) ou pela quarta edição revisada do Manual Diagnóstico e Estatístico de Transtornos Mentais (APA, 2002), não teríamos maiores dificuldades em afirmar que o paciente teria um diagnóstico de dependência ao álcool. É evidente o preenchimento de diferentes critérios diagnósticos, tais como: indícios de dependência química (desenvolvimento de síndrome de abstinência com a diminuição ou interrupção do uso da substância); descontrole em relação ao uso da substância (gasta mais dinheiro do que gostaria, não resiste ao convite dos colegas para beber); problemas de ordem física, psíquica e/ou social decorrentes do uso da mesma (problemas de falta ao trabalho, violência doméstica). Porém, é preciso atentar 
para o fato de que o paciente indígena do caso relatado reside em área urbana há mais de 30 anos, e que veio à consulta devido a problemas laborativos ligados ao uso de álcool. Teríamos a mesma facilidade caso avaliássemos indígenas que vivem nas aldeias?

Há pelo menos uma década, evidências internacionais apontam que critérios diagnósticos utilizados para a identificação de dependência ao álcool em populações não indígenas não são amplamente aplicáveis entre indígenas (Kunitz \& Levy, 1994; Oyacer \& Ñanco, 1998).

A fragilidade desses critérios foi reafirmada quando avaliamos a validade teórica do Cage, um instrumento habitualmente utilizado para a triagem de dependência ao álcool entre os indígenas aldeados do Alto Rio Negro (Souza, Schweickardt \& Garnelo, 2007). Esse instrumento é composto por quatro perguntas. ${ }^{7}$ Quando duas ou mais dessas perguntas são respondidas positivamente, considera-se que o sujeito está em risco de ter dependência ao álcool.

Em nossa pesquisa, além de fazermos tais perguntas, buscávamos compreender o motivo pelo qual o entrevistado respondia sim ou não às diferentes indagações. Nosso propósito era analisar a correspondência entre a motivação do entrevistado em responder afirmativamente ou negativamente e o critério diagnóstico que o instrumento se propunha a investigar com cada pergunta. Nessa investigação, as respostas obtidas para a primeira e a terceira perguntas foram idênticas. Os motivos apontados para desejar diminuir ou parar de beber foram os mesmos que faziam as pessoas se sentirem incomodadas pela forma como bebiam.

As semelhanças entre as respostas dadas à primeira e à terceira pergunta indicam que, embora o instrumento vise a investigar dois aspectos diferentes da dependência ao álcool, a população entrevistada entendia que ambas as perguntas referiam-se a um único fenômeno. Sendo o Cage um instrumento composto por quatro itens, e sendo o teste considerado positivo quando duas respostas são afirmativas, concluímos que a junção das duas questões, expressa nas respostas idênticas dos entrevistados, tenderia a incrementar o número de casos falso-positivos.

7 Este é um questionário padronizado proposto por Ewing e Rouse, em 1970 (Mansur \& Monteiro, 1983). O instrumento é composto por quatro perguntas: C (Cut-Down) 'Alguma vez o Sr.(a) sentiu que deveria diminuir a quantidade de bebida ou parar de beber?'; A (Annoyed) 'As pessoas o aborrecem porque criticam (ou censuram) o seu modo de beber?'; G (Guilty) 'O Sr. se sente culpado pela maneira como costuma beber?'; E (Eyeopener) 'O Sr. Costuma beber pela manhã para diminuir o nervosismo ou a ressaca?'. 
Já as respostas à segunda pergunta do questionário foram de difícil avaliação. A maioria dos entrevistados respondeu negativamente a essa questão. Quando a conversação foi aprofundada para se apreender os motivos da resposta, o que não está previsto na aplicação clássica desse instrumento, percebeu-se que muitos dos entrevistados eram, rotineiramente, aconselhados ou criticados por seus corresidentes, em decorrência de seu modo de beber, mas que não se aborreciam com isso. Alguns entrevistados até consideravam positivos os conselhos e as críticas que recebiam, julgando-os, de fato, uma obrigação de seus parentes próximos. Nota-se, portanto, que a ideia de que a crítica ou o aconselhamento seria percebido como uma afronta à liberdade individual está implícita no Cage. Trata-se de um pressuposto etnocêntrico, ${ }^{8}$ ligado à construção da individualidade nas sociedades contemporâneas urbanas.

As sociedades indígenas rionegrinas, tal como outras etnias que vivem em território brasileiro, não estão centradas na dicotomia individual/coletivo (Segger, DaMatta \& Viveiros de Castro, 1987). Assim sendo, a individualidade nessas sociedades não tem a mesma importância que assume nos contextos urbanos, nos quais o Cage originalmente foi formulado. Em tais circunstâncias, o que a pesquisa evidenciou foi um desencontro entre as premissas que orientam a construção do instrumento e as especificidades da realidade cultural em que ele foi aplicado, inviabilizando uma aferição precisa das respostas às questões supracitadas naquelas sociedades indígenas.

A última pergunta do Cage tem como objetivo investigar indícios de sinais e sintomas de abstinência. Ela parte do pressuposto que haveria bebida para ser consumida após um episódio de uso de álcool e que a motivação para beber no dia seguinte estivesse ligada à presença de abstinência. Entretanto, no Rio Negro, como em outras sociedades indígenas, adota-se um padrão de consumo de álcool que é caracterizado por uma ingestão prolongada, só interrompida quando toda a bebida disponível é consumida, não se praticando a estocagem. Havendo um episódio coletivo de libação alcoólica, e a bebida não sendo esgotada no mesmo dia, o rito festivo prosseguirá durante os dias subsequentes, mantendo-se a ingestão de bebida até o seu término.

Em um cenário aldeão, quando a bebida acaba, a festa também costuma se encerrar. Caso se deseje prosseguir o consumo, será necessário reiniciar o trabalhoso preparo das bebidas fermentadas tradicionais ou esperar pela chegada

\footnotetext{
8 Uma clássica e atual definição de etnocentrismo é aquela formulada por Sumner:"visão de mundo na qual o centro de tudo é o próprio grupo a que o indivíduo pertence; tomando-o por base, são avaliados e escalonados todos os outros grupos" (Sumner apud Silva, 1987: 437).
} 
clandestina de bebida industrializada, cuja oferta irregular depende do fluxo de barcos que circulam na região. Ou seja, de acordo com os costumes, as festas e o uso de bebida - podem durar vários dias, após os quais os limites de acesso ao álcool instituem uma pausa obrigatória no consumo.

Em tal cenário, as respostas dadas a essa pergunta do Cage não permitiam distinguir os sujeitos que bebiam no dia seguinte porque a festa continuava, por ter 'sobrado' ainda bebida, daqueles que bebiam no dia seguinte para combater os sinais de abstinência. Foi igualmente impossível caracterizar se os que não bebiam no dia seguinte não o haviam feito pela indisponibilidade de bebida, ou por não sentirem os sintomas de abstinência.

As conclusões dessa pesquisa não negam a possibilidade da existência de quadros de dependência ao álcool na população indígena estudada. Porém, evidenciam, por meio da análise dos limites de um instrumento de uso corrente como o Cage, as fragilidades de critérios diagnósticos concebidos para serem universais, cujo uso mostrou-se questionável em um contexto culturalmente específico. Situações como essa deveriam ser levadas em consideração quando se analisam resultados de pesquisas que apontam para uma maior prevalência de dependência ao álcool entre populações indígenas quando comparados à população não indígena.

\section{Problemas Relacionados ao Uso de Álcool: um conceito polimorfo...}

A ideia de 'problemas relacionados ao uso do álcool' refere-se aos efeitos adversos associados ao uso de bebida alcoólica, independentemente de o padrão de ingesta do sujeito configurar uma situação de dependência. ${ }^{9}$ Dada sua própria natureza, esse conceito é aberto e polimorfo, visto que a fronteira que separa um beber normal de um problemático está estreitamente relacionada às dimensões socioculturais e históricas do beber (Edwards et al., 1999). Comparado ao conceito de dependência ao álcool, constitui-se em um conceito mais

\footnotetext{
9 Não se deve confundir esse conceito com os diagnósticos de abuso de álcool (APA, 2002) ou uso nocivo de álcool (OMS, 1993). Como destacado nos códigos classificatórios, havendo elementos suficientes para um diagnóstico de dependência, os diagnósticos anteriores são descartados, o que não se aplica quando se trabalha com "problemas relacionados ao uso de álcool". Ademais, quando se trata de abuso ou uso nocivo, independentemente a que tipo de substância, previamente se estabelece o que deve ser considerado como característico dessas formas disruptivas de beber, o que difere, como se verá a seguir, do que é estabelecido por esse conceito.
} 
amplo, associando-se tanto às ciências sociais quanto à biomedicina. Abrange não apenas os problemas de saúde, mas permite contextualizar o beber no espaço social, cultural e histórico que cerca o usuário de álcool.

Oyacer e Nanco, que trabalharam com os indígenas Mapuche, do Chile, sintetizam a relação entre problemas relacionados ao uso de álcool e à cultura, ao afirmarem que

o beber é uma conduta e como tal não pode ser definida fora de seu contexto sociocultural, [e que] as patologias relacionadas com condutas e que implicam definições de normal e anormal podem variar de uma cultura para outra. (Oyacer \& Ñanco, 1998: 36)

No caso clínico descrito, um dos aspectos que levava a filha do paciente a identificar a forma de beber do pai como problemática era o fato de que ele estava em vias de perder seu emprego, em virtude de suas faltas ao trabalho ou do comparecimento alcoolizado. Embora o paciente fosse indígena, seu problema relacionado ao uso do álcool estava mais ligado a um modo de vida urbano-ocidental - no qual existem regras específicas, implícitas ou explícitas, de frequência e sobriedade no trabalho - do que a um padrão de consumo característico da vida em aldeia.

Como identificamos em pesquisa realizada em comunidades indígenorurais do Alto Rio Negro (Souza \& Garnelo, 2007), uma das situações tidas como adequadas para se consumir bebidas alcoólicas eram os momentos nos quais se realizavam trabalhos coletivos para a instalação de novas roças, ou atividades similares. Nessas situações, as pessoas consumiam bebidas alcoólicas antes, durante e após a atividade.

Dados os padrões culturais vigentes, nos quais os momentos de conjugação coletiva de esforços promovem a reafirmação dos vínculos sociais e costumam ser pontuados pelo uso coletivo de álcool, a recusa da bebida, nesse contexto, é que poderia ser considerada como um comportamento problemático. Além do mais, se desconsiderássemos ou desconhecêssemos o contexto cultural vigente, poderíamos avaliar equivocadamente o padrão de consumo de um indígena aldeado, considerando-o problemático, caso tivéssemos apenas a informação (descontextualizada) que ele trabalhava sob efeito de álcool.

Retomando o caso do paciente supracitado, outro aspecto apontado por sua filha para caracterizar o beber do pai como problemático foi o fato de ele se tornar agressivo, quando alcoolizado. Num primeiro olhar, beber e ficar violento 
parece ser um indício inegável de um beber problemático, nos mais variados contextos socioculturais, principalmente se analisarmos esses fatos através do prisma da biomedicina, para a qual a violência é essencialmente vista como um agravo à saúde (Minayo, 2003). Então, se ao avaliarmos um paciente obtivéssemos a informação de que ele é uma pessoa calma, cordial e educada, mas que, quando bebe, costuma ficar violento, tenderíamos a enquadrá-lo numa situação de 'beber problema'. Porém, quando se trata de populações indígenas, sobretudo as não urbanizadas, os termos da situação podem se tornar mais complexos. Em tukano, uma das línguas indígenas faladas em extensas áreas do Alto Rio Negro, ke'ág é a palavra utilizada para se referir à pessoa do sexo masculino que está alcoolizada. Ke'á pode ser utilizada como verbo intransitivo, significando 'estar embriagado', ou como verbo transitivo, significando 'espreitar', ou 'ficar de tocaia' (Ramirez, 1997). Observa-se, portanto, a fusão, em uma mesma palavra, das ideias de bêbado e de alguém com um potencial beligerante.

Além disso, em diferentes mitos rionegrinos, as situações de uso de álcool aparecem como o momento para a resolução de conflitos latentes, através da violência; ${ }^{10}$ trata-se de uma situação social que favorece a organização de tocaias e a morte dos inimigos (Souza, 2004). Nas observações de campo, raramente pôde-se ver, ou ouvir falar, de embates corporais perpetrados por pessoas sóbrias, ao passo que as tensões e os conflitos contidos no cotidiano surgiram como algo relativamente circunscrito aos momentos de consumo de bebidas alcoólicas, quando costumam eclodir abertamente.

Ter acesso a esse tipo de informação não nos autoriza, no caso do paciente analisado, a desconsiderar a violência interpessoal ou as idas alcoolizadas ao trabalho como indício de um 'beber problema', alegando que esses comportamentos seriam 'normais' no caso de um indígena. Em ambas as situações, estaríamos desconsiderando o contexto no qual o consumo de álcool foi feito, contrariando a proposta de Oyacer e Ñanco (1998), anteriormente citada, e a capacidade de mudança dos sujeitos e suas culturas, em resposta às condições de vida encontradas.

10 Em outros mitos, no momento de consumo de caxiri, pessoas anteriormente litigantes podem fazer as pazes; ou inimigos declarados podem deixar, temporariamente, suas diferenças de lado. De qualquer forma, no momento de consumo de caxiri, os conflitos latentes tendem a ser resolvidos, seja pela sua explicitação (resultando em violência) ou pelo congraçamento entre os rivais. 


\section{Alcoolização: um conceito oriundo das ciências sociais}

O conceito de alcoolização trabalhado nesta seção é mais amplo que os anteriores, e está ligado, de forma mais clara, ao domínio das ciências sociais, visto que se associa ao significado que o beber assume em uma dada cultura, independentemente de ser problemático ou não. Menendez define alcoolização como

o conjunto de funções e consequências positivas e negativas que cumpre a ingesta de álcool para conjuntos sociais estratificados, e não apenas o estudo dos alcoólicos dependentes, nem os excessivos, nem os moderados, nem os abstêmios, mas sim o processo que inclui a todos e que evita considerar o problema em termos de saúde e/ou enfermidade mental. (Menendez, 1982: 36)

Esse conceito traz, de forma clara, a necessidade de contextualizar o uso de álcool na cultura e na história, e não apenas o uso problemático. Busca, em última análise, o significado que tem o beber para um dado grupo, em um determinado momento e contexto. A aplicação desse conceito permite-nos, por um lado, avaliar de forma menos etnocêntrica quando o beber se torna um problema, tal como discutido na seção anterior. Por outro lado, ela propicia um aprofundamento da compreensão das transformações nos modos de beber, em face das mudanças vivenciadas por grupos ou indivíduos, assim como das possíveis vulnerabilidades advindas desse processo.

Retornando ao relato do caso-clínico, poderíamos ser tentados a admitir, como indício de que algo problemático estaria ocorrendo na vida do paciente, o fato de ele ter iniciado o consumo de bebidas alcoólicas ainda na infância. Nesse caso, estaríamos emitindo um juízo sobre eventos oriundos de uma realidade cultural específica e diferenciada, utilizando parâmetros adequados para a emissão de juízos sobre a nossa própria sociedade, ou seja, estaríamos sendo etnocêntricos. Então, para proceder de modo culturalmente sensível, deveríamos, pelo contrário, buscar avaliar os problemas com o uso de álcool a partir das regras próprias dos contextos sociais que os produzem, o que se torna possível ao adotarmos o conceito de alcoolização.

Com base nesse conceito, em outra pesquisa realizada entre populações indígenas do Alto Rio Negro, buscamos investigar os modos atuais de consumo 
de bebidas alcoólicas, ou seja, o que se bebe, como se bebe e quando se bebe, e também apreender as modificações e ressignificações associadas ao beber, segundo o ponto de vista nativo (Souza \& Garnelo, 2007).

No contexto investigado, observamos que o chamado 'caxiri fraco' não é considerado uma bebida, e sim um alimento, sendo introduzido na dieta das crianças entre os 3 ou 4 anos de idade. Ademais, a literatura demonstra que essa não é uma prática exclusiva dos índios rionegrinos, sendo compartilhada pelos Kaxináwa, Yamináwa, Kulína e Kaingáng (Oliveira, 2003). O caxiri forte, este sim, era considerado uma bebida e passava a ser consumido após o ritual de iniciação masculino, por volta dos 13 ou 14 anos de idade.

Vimos, também, que, atualmente, mesmo nas terras indígenas, a cachaça vem fazendo parte do repertório de bebidas alcoólicas consumidas, e que o hábito de beber tudo o que estiver disponível mantém-se, mesmo se o que se consome for cachaça. Existem, porém, diversos fatores distintivos que regulam esse consumo. Dentre eles, destacamos o alto preço que essa bebida adquire nas comunidades, a irregularidade da sua oferta (em virtude das grandes distâncias entre as aldeias e a sede municipal onde a cachaça é adquirida) e as regras de etiqueta que impelem os que possuem dinheiro a comprá-la e a dividi-la com outras pessoas, demonstrando generosidade e garantindo prestígio. Todos esses são fatores que limitam o uso individual e indiscriminado de cachaça.

Tradicionalmente, as situações tidas como adequadas para se consumir bebidas eram os ritos festivos e, como visto antes, as situações de trabalhos coletivos, denominadas ajuri. Porém, ao longo da história de contato entre as sociedades indígenas e a sociedade brasileira, houve um incremento significativo das situações festivas. Esse incremento deu-se, em grande medida, pela incorporação das datas comemorativas do calendário cívico e religioso brasileiro às situações em que a bebida é considerada aceitável entre os indígenas. Mesmo nesse contexto de mudanças, o padrão de consumo é essencialmente coletivo, sendo raro, e considerado inadequado, o consumo individual ou microgrupal.

Se fizermos uma análise do caso clínico de consumo problemático anteriormente relatado utilizando o conceito de alcoolização, devemos considerar as mudanças ocorridas na vida do paciente a partir do processo de cristianização e do afastamento das formas tradicionais de vida. Tais mudanças propiciaram, dentre outras alterações de comportamento e valores, a adoção de uma moral católica, que contribuiu para indispor o paciente com seu irmão. O contato interétnico também propiciou ao paciente uma nova profissão e criou a 
necessidade de adquirir bens, tornando o trabalho remunerado uma necessidade. Esse conjunto de eventos motivou sua migração para a cidade.

No espaço urbano, o paciente de origem indígena em questão passou a exercer ocupações precárias, sendo destituído do status do qual gozava antes. A socialização com os colegas de trabalho era feita nos encontros em bares, onde se dava a ingestão de álcool. O acesso constante à bebida, propiciado pelo salário, sem as limitações do consumo tradicional, e potencializado pela oferta irrestrita, característica da vida da cidade, associado ao consumo pautado por uma lógica urbana (o trago após o trabalho), contribuíram para a rotinização do uso da cachaça e para a instalação de um quadro de dependência ao álcool (Souza, 2005).

\section{Considerações Finais: a 'generalização conceitual'}

Ao longo do texto, fez-se um contraponto entre o caso clínico de um paciente indígena urbanizado e os modos de beber nas comunidades indígenas. A comparação entre o 'beber problema' em meio urbano e os modos de beber nas comunidades será o foco de atenção nesta seção final. Por meio dela, buscar-se-á promover o diálogo entre os aspectos teórico-conceituais aqui apresentados e as propostas para ação nos serviços de saúde mental, na área de álcool e drogas.

A base da prática diagnóstica e terapêutica da psiquiatria funda-se, na sua atuação histórica, nos hospitais e manicômios. Constitui-se num saber que parte do pressuposto de que há um sujeito (tido como) gravemente doente, que busca - ou é levado a - um serviço que o aparta do seu meio sociocultural e que ignora e silencia sua subjetividade e singularidade (Goffman, 1974). O exercício diagnóstico constitui-se em identificar, por meio de sinais e sintomas predefinidos nos manuais de psiquiatria, o que há em comum entre histórias de vida distintas.

Na prática hospitalar, os próprios pacientes, ou pessoas próximas a ele, identificaram algo de disruptivo no seu modo de beber. Quando demandam os serviços de saúde, via de regra, já esgotaram os recursos familiares e comunitários de atenção-cura-cuidados acionados para lidar com a situação problemática. Em tais circunstâncias, ocorre uma espécie de pré-diagnóstico: 'algo diferente (e ruim) está ocorrendo; fizemos tudo que podíamos, mas não conseguimos resolver'. 
Entretanto, a busca por um modelo assistencial interessado em trabalhar não apenas com o indivíduo, mas também preocupado com intervenções abrangentes, voltadas para a família e para a comunidade, teria que buscar ferramentas para integrar, ao invés de apartar, as variáveis socioculturais; acolher, escutar e dar a voz, ao invés de ignorar e silenciar, as singularidades que emergem em cada caso.

Numa prática comunitária de alta capilaridade, é possível que pessoas sejam identificadas no seu meio social e pela própria equipe de saúde como merecedoras de atenção especializada em virtude de seu modo de beber. Se, por um lado, é possível identificar precocemente casos que poderiam evoluir para quadros mais graves; por outro, corre-se o risco de 'patologizar' um comportamento considerado normal em um contexto específico.

Os critérios que embasam o diagnóstico biomédico de dependência ao álcool não pairam em um campo de plena certeza para que possam ancorar uma atuação de tipo comunitário. Como foi visto anteriormente, por meio da problematização da validade teórica do Cage, os critérios diagnósticos podem se mostrar falhos quando utilizados contextos socioculturais diferenciados. Tal fato se agrava quando lembramos que a população indígena rionegrina é apenas uma das inúmeras e variadas formações sociais existentes no país.

Critérios diagnósticos são pensados para serem universais, porém a realidade é multifacetada. Ademais, ainda que se supusesse haver uma validade ampla e geral dos critérios, esta pouco auxiliaria nas ações de cuidado sejam individuais ou coletivas. O que de fato um diagnóstico de dependência ao álcool auxiliaria em um planejamento plano terapêutico individual ou coletivo? A realização desse diagnóstico não nos informa, como terapeutas ou como pacientes, que a interrupção do uso de bebidas alcoólicas seria a meta a ser perseguida (Ramos \& Woitowitz, 2004) e, muito menos, que seria suficiente, por si só, para convencer um sujeito, ou um grupo de pessoas, que seu modo de beber merece ser repensado.

Em abordagens sociocomunitárias, a categoria 'problemas relacionados ao uso do álcool' surge como um possível ponto de ancoragem, não por sua objetividade, mas justamente pela sua maleabilidade e possibilidade de adaptação aos diversos settings passíveis de existência. A utilidade potencial dessa categoria está em buscar identificar, do ponto de vista do sujeito, da família, do grupo social ou da comunidade, quando uma forma de beber deve ser repensada. Ao utilizá-la seria possível minimizar o olhar etnocêntrico sobre o modo de beber 
de grupos socioculturais diversos e limitar o risco de 'patologizar' o comportamento considerado 'normal' naquele contexto.

Nas abordagens individuais e, sobretudo, nas coletivas, seria possível customizar uma categoria que nortearia caminhos de intervenção, passíveis de negociação a cada situação social. Ao se buscar, por exemplo, traçar estratégias preventivas para diferentes grupos existentes em um determinado território, sejam escolares, minorias étnicas ou moradores de rua, identificar o que seria, para eles, uma forma problemática de beber constitui um importante ponto de partida. Nas abordagens individuais, identificar, juntamente com o paciente e, se for o caso, com sua família aspectos de seu beber que são problemáticos, pode auxiliar na produção de estratégias de redução de danos passíveis de adesão pelos sujeitos. Ademais, seja no contexto coletivo ou individual, a reflexão dialógica a ser estabelecida permitirá que os profissionais da saúde questionem e sejam questionados sobre qual deveria ser a forma de uso não problemático de bebida, influenciando e sendo influenciados pelos sujeitos e grupos com os quais interagem.

Entretanto, para acessar e compreender, mesmo parcialmente, o que seria uma forma problemática de se beber, é necessário apreender os modos de beber tidos como adequados em cada contexto de atuação das equipes de saúde, o que pode ser propiciado pelo conceito de alcoolização, desde que haja sensibilidade para se entender, como nos recomenda Langdon (2001), quando, como, quanto e o que se bebe.

No contexto da ação de um serviço de saúde mental, essas informações podem ser obtidas de diferentes formas, seja pela participação em eventos comunitários, seja pela escuta e interação proativa com agentes comunitários da saúde, valorizando seus conhecimentos sobre a vida na comunidade. Além disso, nas avaliações individuais, outra estratégia seria ir além da coleta de histórias clínicas limitadas à enumeração de sinais e sintomas. Nesses casos, dever-se-ia buscar acessar, de forma empática e interessada, as histórias de vida dos bebedores e traçar, sob o olhar do paciente, semelhanças e diferenças entre o seu modo particular de beber e o das pessoas que o cercam.

O exercício aqui proposto foi o de pensar o geral a partir do particular, e não o inverso, como ensinado pela tradição clínica. Quando conceitos generalizantes como os diagnósticos são levados para contextos específicos, sobretudo aqueles relacionados ao uso de álcool, corre-se o risco de se perder seu poder heurístico e de sua utilidade tornar-se questionável. Por isso, aponta-se, aqui, a fragilidade do conceito de dependência ao álcool e valoriza-se a potencialidade 
de conceitos como o de problemas relacionados ao uso de álcool e alcoolização. Esses conceitos mostram-se úteis não apenas quando se investiga o uso de álcool em populações indígenas, residentes em remotas áreas da Amazônia, mas também quando se traçam estratégias para atuação de serviços de saúde mental de base comunitária numa grande ou pequena cidade.

\section{Referências}

AMERICAN PSYCHIATRIC ASSOCIATON (APA). Manual Diagnóstico e Estatístico de Transtornos Mentais. Porto Alegre: Artes Médicas, 2002. (Texto Revisado - DSM IV-R)

COIMBRA JR., A. E. \& SANTOS, R. V. Saúde, minorias e desigualdades: algumas teias de inter-relações, com ênfase nos povos indígenas no Brasil. Ciência \& Saúde Coletiva, 5(1): 125-132, 2000.

DESLANDES, S. F \& ASSIS, S. G. Abordagens quantitativa e qualitativa em saúde: o diálogo das diferenças. In: MINAYO, M. C. S. \& DESLANDES, S. F. (Orgs.). Caminhos do Pensamento: epistemologia e método. Rio de Janeiro: Editora Fiocruz, 2002.

EDWARDS, G. et. al. O Tratamento do Alcoolismo: um guia prático para profissionais de saúde. 3. ed. Porto Alegre: Artes Médicas, 1999.

FUNDAÇÃO NACIONAL DO ÍNDIO (FUNAI). Povos Indígenas. Disponível em:<www.funai. gov.br>. Acesso em: 30 jun 2008.

GARNELO, L.; MACEDO, G. \& BRANDÃO, L. C. Os Povos Indígenas e a Construção das Políticas de Saúde no Brasil. Brasília: Opas, 2003.

GARNELO L. \& LANGDON E. J. A antropologia e reformulação das práticas sanitárias. In: MINAYO, M. C. S. \& COIMBRA JR., A. (Orgs.). Críticas e Atuantes: ciências sociais e humanas em saúde na América Latina. Rio de Janeiro: Editora Fiocruz, 2005.

GEERTZ, C. A Interpretação das Culturas. Rio de Janeiro: Livros Técnicos e Científicos Editora, 1989.

GOMES, M. P. O Índio na História: o povo Tenetehara em busca de liberdade. Petrópolis: Vozes, 2002.

GOFFMAn, E. Manicômios, Prisões e Conventos. São Paulo: Perspectiva, 1974.

HUGH-JONES, S. The Palm and the Pleiades: initiation and cosmology in Northwest Amazonia. Cambridge: Cambridge University Press, 1979.

JACKSON, J. E. The Fish People: linguistic exomamy and Tukanoan identity in Northwest Amazon. Cambridge: Cambridge University Press, 1983. 
KUNITZ, S. J. \& LEVY, J. E. Drinking Careers: a twenty five-year study of three Navajo populations. New Haven, London:Yale University Press, 1994.

LANGDON, E. J. O que beber, como beber e quando beber: o contexto sociocultural no alcoolismo entre as populações indígenas. In: SEMINÁRIO SOBRE ALCOOLISMO E DST/AIDS ENTRE OS POVOS INDÍGENAS. Londrina, 1999. Brasília: Ministério da Saúde/ Secretaria de Políticas de Saúde/Coordenação Nacional de DST e Aids, 2001.

LASMAR, C. De Volta ao Lago de Leite: gênero e transformação no Alto Rio Negro. São Paulo, Rio de Janeiro: Editora Unesp, ISA, Nuti, 2005.

LiMA, D. \& POZZOBON, J. Amazônia socioambiental: sustentabilidade ecológica e diversidade local. Estudos Avançados, 19(54): 45-76, 2005.

MANSUR, J. \& MONTEIRO, M. J. Validation of the 'CAGE' alcoholism screening test in a Brazilian psychiatric inpatient hospital setting. Brazilian Journal of Medical and Biological Research, 16:215-218, 1983.

MENENDEZ, E. L. El proceso de alcoholización: revisión crítica de la produción socioantropologica, histórica y biomédica en America Latina. Revista Centroamericana de Ciencias de la Salud, 22:61-94, 1982.

MESSAS, G. P. \& VALLADA FILHO, H. P. O papel da genética na dependência ao álcool. Revista Brasileira de Psiquiatria, 26, supl. I: 54-58, 2004.

MINAYO, M. C. S. A violência dramatiza causas. In: MINAYO, M. C. S \& SOUZA R. E. (Orgs.). Violência sob o Olhar da Saúde: a infra-política da contemporaneidade brasileira. Rio de Janeiro: Editora Fiocruz, 2003.

OLIVEIRA, J. P. Uma etnologia dos "índios misturados"? Situação colonial, territorialização e fluxos culturais. Mana, 4(1): 47-77, 1998.

OLIVEIRA, M. Uso de bebidas alcoólicas e alcoolismo entre os Kaingang da Bacia do Rio Tibagi: uma proposta de interveção. In: JEOLAS, L. S. \& OLIVEIRA, M. (Orgs.). Anais do Seminário Cultura, Saúde e Doença. Londrina: Secretaria Municipal de Londrina, 2003.

ORGANIZAÇÃO MUNDIAL DA SAÚDE (OMS). Classificação de Transtornos Mentais e de Comportamento da CID-10. Porto Alegre: Artes Médicas, 1993.

OYACER, A. M. \& ÑANCO, J. Alcoholismo y etnia: críticas y propuestas. In: SALGADO, M. S. \& MELLA, I. J. (Orgs.). Salud, Cultura y Territorio: bases para una epidemiología intercultural. Lincanray: Ministerio de Salud Chile, 1998.

PAGLiARO, H.;AZEVEDO, M. M. \& SANTOS R.V. (Orgs). Demografia dos Povos Indígenas no Brasil. Rio de Janeiro: Editora Fiocruz, 2005.

PEIRANO, M. A Favor da Etnografia. Rio de Janeiro: Relume-Dumará, 1995.

RAMIREZ, H. A Fala Tukano dos Ye'pâ-masa. Manaus: Cedem, 1997. 
RAMOS, S. P. \& WOITOWITZ, A. B. Da cervejinha com os amigos à dependência de álcool: uma síntese do que sabemos sobre este percurso. Revista Brasileira de Psiquiatria, 26, supl I: 18-22, 2004.

SEGGER, A; DAMATTA, R \& VIVEIROS DE CASTRO, E. B. A construção da pessoa nas sociedades indígenas brasileiras. In: OLIVEIRA FILHO, J. P. (Org.). Sociedades Indígenas e Indigenismo no Brasil. Rio de Janeiro: Marco Zero, 1987.

SILVA, B. Dicionário de Ciências Sociais. 2. ed. Rio de Janeiro: Fundação Getúlio Vargas, 1987.

SOUZA, M. L. P. Alcoolização e Violência no Alto Rio Negro, 2004. Dissertação de Mestrado em Sociedade e Cultura na Amazônia, Manaus: Instituto de Ciências Humanas e Letras, Universidade Federal do Amazonas.

SOUZA, M. L. P. Vulnerabilidade à dependência ao álcool em paciente indígena: relato de caso. Psychiatry On-Line Brazil, 10 jan. 2005. Disponível em: <www.polbr. med.br>. Acesso em: 25 jul. 2011.

SOUZA, M. L. P. \& GARNELO, L. Desconstruindo o alcoolismo: notas a partir da construção do objeto de pesquisa no contexto indígena. Revista Latinoamericana de Psicopatologia Fundamental, IX(2): 279-292, 2006.

SOUZA, M. L. P. \& GARNELO, L. Quando, como e o que se bebe: o processo de alcoolização entre populações indígenas do alto Rio Negro, Brasil. Cadernos de Saúde Pública, 23(7): 1.640-1.648, 2007.

SOUZA, M. L. P.; SCHWEICKARDT, J. C. \& GARNELO, L. O processo de alcoolização em populações indígenas do Alto Rio Negro e as limitações do Cage como instrumento de screening para dependência ao álcool. Revista de Psiquiatria. Clínica, 34(2): 90-96, 2007. 


\title{
Surtado ou Assustado?
}

\section{Algumas considerações sobre violência e cuidado no contexto dos serviços territoriais de saúde mental e atenção psicossocial'}

\author{
Nina Isabel Soalheiro Prata \\ Cada vez o Brasil fica mais poluído, \\ horrível, violento, pobre e morto, e cada 21\% de pessoas são ricas \\ no Brasil inteirinho! E cada 247\% de pessoas no Brasil são pobres (...) \\ Ou alguém para essa coisa ou o mundo vai despedaçar!
}

Lara e Carol, 7 e 9 anos, em seu Livro sobre a Pobreza

O presente trabalho aborda a temática da violência e do cuidado na prática cotidiana dos serviços territoriais de atenção psicossocial. Embora possa parecer que essa questão se apresente com mais urgência de debate no cotidiano dos serviços para atenção diária às pessoas que fazem uso prejudicial de álcool e outras drogas, trata-se de um problema comum a todos os serviços de saúde mental. Assim, o tempo que vivemos exigiria um esforço de resistência e construção de novas estratégias para o enfrentamento da violência no território, um trabalho decidido de fortalecimento dos coletivos e construção de uma cultura do cuidado baseada na potência dos afetos e da solidariedade.

A vulnerabilidade das nossas instituições à violência do entorno, seus códigos e mandatários parecem ter uma relação direta com a fragilidade dos processos coletivos e o abandono, pela equipe, do acompanhamento dos laços afetivos e sociais que se fazem a partir da convivência. O modelo Caps/casa vem sucumbindo à complexidade da realidade urbana, da miséria e da cultura de rua, aproximando-nos perigosamente da violência e do caos.

\footnotetext{
Texto apresentado em 2008 em seminário interno da equipe do Caps onde a autora trabalhava na época.Atualmente é professora/pesquisadora da Escola Politécnica de Saúde Joaquim Venâncio da Fundação Oswaldo Cruz (EPSJV/Fiocruz).
} 
O entendimento das nossas instituições como espaços públicos dotados de uma complexidade própria parece apontar saídas, como o fortalecimento dos vínculos e dos coletivos e a valorização da dimensão política das práticas e das redes de solidariedade entre aqueles que - apesar do abandono e desamparo - fazem a opção pela dignidade, pela vida e pelos valores que a sustentam.

Numa sexta-feira comum, de muito trabalho, num Caps situado no extremo oeste do Rio de Janeiro, recebo um telefonema vindo da sede da coordenação do estado, no centro da cidade. Um pedido de acolhimento para uma mãe desesperada que teria ido até lá pedir ajuda para seu filho enlouquecido. Acertado tudo, a mãe vem no dia seguinte: uma senhora idosa que, antes de conseguir dizer qualquer coisa, chora de cansaço e tristeza diante de mim. Seu filho, muito jovem, está em casa, atormentado, insone, agitado, violento. Penso, nesse momento, que a mãe foi procurar no centro da cidade o Estado que não encontra em seu território, onde 'tá tudo dominado'. Me conta que o filho era usuário de drogas, mas adoeceu e acabou ficando refém das suas relações em torno da droga e das suas alucinações, agora sem alucinógenos. Seu comportamento enlouquecido tornou-se uma ameaça para a milícia que domina a área, trazendo riscos para o seu filho. Ela só se acalma com a promessa de que iremos à sua casa, ao seu território.

$\mathrm{Na}$ data combinada, chegamos num carro quase sem identificação, conduzidos por um motorista terceirizado que não conhecia o lugar, e nos deparamos com um carro prateado, luxuoso e reluzente, cercado por alguns homens, que não deixavam dúvidas quanto ao seu domínio daquele território, já nos examinando e permitindo a nossa entrada. Encontramos uma cena comum nesses casos, um jovem assustado, delirante, olhos esbugalhados, pronto para reagir à nossa invasão de sua casa - uma casa coletivizada, onde mora com a mãe, avó, muitas crianças. Ele não estava em condições de conversar, acuado, defensivo, delirante, negando qualquer tipo de ajuda. Uma vizinha que chegou para ajudar tentou uma aproximação afetiva, mas infrutífera. Depois de muitas tentativas de convencimento, decidiu-se então por uma medicação forçada e saímos, eu e a mãe, para procurar ajuda com vizinhos para a sua contenção. Nesse momento, ela olha para os homens da milícia e diz: 'Eles não, pelo amor de Deus!'.Um outro vizinho acaba nos acompanhando relutante, dizendo que o jovem 'tem muita força'. Entramos novamente, a cena era a mesma, só que agora ele gritava com veemência: 
'Eu só quero paz, me deixem em paz, eu só quero paz!' Nessa hora, os anos de profissão não amenizam em nada a angústia diante do ato - naquele momento considerado por todos inevitável - da contenção física. É então que vejo os milicianos adentrar pela porta, sem pedir licença; querem restabelecer a ordem no seu território. Percebo o desespero da mãe, enquanto o chefe deles tenta, ainda em pé, dominar com os olhos, intimidar, controlar o jovem. Mas ele não consegue e, com uma discreta irritação, constata que aquele não está mais susceptível ao seu controle, está fora de si. Por fim, para minha indignação, deposita ao meu lado uma arma metálica e reluzente como o carro, para conseguir se abaixar e fazer com tranquilidade uma contenção competente, que possibilita que o paciente seja medicado. Fico paralisada, me perguntando o que eu estava fazendo ali, ao lado daquela arma, envolvida com aquele homem e seus seguranças. Mas eles saem tranquilamente de cena da mesma forma que entraram. A mãe está muito abalada, convido-a para ir conosco ao Caps, deixar um pouco o filho aos cuidados de outros, participar do encontro semanal dos familiares, talvez assim ela pudesse se sentir melhor. Ela aceita prontamente, mas depois fica insegura, prefere ficar com o filho e ir outro dia.

Na volta ao Caps, muito afetada, vou falando no carro sobre as diversas sensações que me atingem. Por fim, ainda assustada, me refiro ao jovem:'Ele estava muito assustado!'. Mas alguém retruca: 'Assustado? Ele tá é surtado!'. A minha indignação ficou ainda maior: 'Cadê o Estado'?,'Nós somos o Estado?', 'Rede com a milícia?', 'Contenção com arma?'. Chegando ao Caps, ao me reunir com os familiares, contei a história do dia, dividindo com eles o horror de sermos reféns de tudo isso. E ficamos ali, conversando, eu e aquelas mães, pais, irmãos, pessoas que se relacionam cotidianamente com a violência, que já perderam muitos jovens, que defendem os filhos vivos e doentes até a morte, constatando que, felizmente, ali estávamos todos muito assustados e indignados.

A mãe retorna depois para dizer que o filho teve uma melhora significativa, aceitou acompanhá-la a um centro de saúde próximo à sua casa, foi acolhido e estava em tratamento lá, e que queria apenas garantir que ela própria pudesse continuar voltando ao Caps. Comigo ficaram as questões: uma rede foi feita ali, algum Estado existiu, pessoas, instituições, todos muito precários, muito longe da paz. 


\section{Violência e Cuidado no Cotidiano dos Caps}

Vivemos hoje, nos Caps, um momento difícil, que exige um grande esforço de enfrentamento, na convivência com os usuários e no cotidiano da instituição, da insidiosa presença da violência no interior das nossas relações. Convivemos com agressões, mortes, assassinatos, desaparecidos e pacientes envolvidos e vítimas do tráfico, trazendo sua linguagem, seus códigos, seus subprodutos. A violência do entorno, entrando pela nossa porta, obriga-nos a pensar na falta de estrutura para lidar com um problema dessa envergadura, incluindo-nos numa dimensão maior do problema da vulnerabilidade das instituições e políticas públicas.

Lidamos cotidianamente com os revezes das relações humanas e da violência afetiva que se faz presente nelas diante da qual não podemos nos manter neutros. Mas como enfrentar essa dimensão de uma sociedade violenta? Como investir em um trabalho permanente de construção de uma cultura do cuidado, num contexto de tal banalização da vida e dos valores que a sustentam? Seria necessário retomar uma dimensão pedagógica para dar conta da sustentação de coletivos criativos, solidários e fundados nos valores civilizatórios e nos direitos humanos? Sobretudo se falamos de "um direito não dado, não garantido, que afirma a vida em toda a sua potência de criação (...), que implica um desafio permanente de invenção de novas práticas e novos mundos que incluam as diversidades" (CRP-RJ, 2007: 7).

Encontramos em Bezerra Júnior (2007) indicações da importância dessa temática, quando o autor acentua o fato de que a consolidação da reforma psiquiátrica brasileira vem trazendo à tona uma quantidade crescente de desafios, que precisariam ser incorporados à agenda dos campos da saúde mental e da saúde coletiva. Para ele, a construção de um sistema assistencial, um imaginário cultural e uma rede de laços sociais inspirados nos ideais da reforma exigiriam imaginação, criatividade e reflexão crítica diante da realidade de um país de dimensões continentais e enorme diversidade cultural. Por isso, pondera que não seria possível pensar um único modelo assistencial que sirva, igualmente, para as megalópoles e as pequenas cidades do interior, para áreas de grandes concentrações populacionais e regiões de população escassa, enfim, que abarque as diversidades de territórios do nosso país.

Ao discutir alguns aspectos intrínsecos à esfera da clínica, Bezerra Júnior aponta a formação de recursos humanos como um desses desafios, ressaltando 
a dificuldade inerente pelo fato de que, em sua maioria, os profissionais da rede seriam constituídos por jovens que não viveram o processo de luta política e ideológica que envolveu a criação do Movimento Antimanicomial e o intenso intercâmbio com intelectuais de referência do movimento, como Basaglia, Foucault, Rotelli e outros. O autor pondera que, além disso, um processo de esvaziamento do debate político e o relativo abandono das grandes bandeiras de transformação política tornariam mais complexo o processo de formação teórica e técnica desses profissionais.

O autor fala, ainda, do que seriam, na sua visão, temas cruciais para a formação de profissionais capazes de levar adiante o processo de transformação defendido pelo ideário reformista: as novas formas de organização das equipes, a transformação dos papéis destinados aos técnicos, o trabalho interdisciplinar e intersetorial, a articulação entre os aspectos clínicos e políticos da atenção psicossocial, o entrelaçamento entre estratégias de cuidado e estratégias de responsabilização ou interpelação do sujeito, e a temática dos direitos humanos e da defesa da dignidade da pessoa, dos direitos civis e sociais. Ressalta, também, a importância de tomarmos isso como desafio para o próprio futuro do movimento, já que este se encontraria num momento estratégico. Para ele, ou o movimento aprofunda seu ideário, deixando claro seu horizonte ético e seu projeto de transformação social e subjetiva, ou corre o risco de deixar-se atrair pela força da burocracia e da institucionalização conservadora.

Em outro momento, o mesmo autor já nos apontava que "nem tudo são flores", referindo-se a um fenômeno presente na rede de serviços do município do Rio de Janeiro: do lado da gestão, entusiasmo e clareza quanto ao projeto de ampliação da rede de Caps; do lado dos trabalhadores dos serviços, muitas aflições, dúvidas e até um certo desânimo quanto ao futuro da proposta.Para ele, o diálogo entre os dois lados seria essencial, bem como o desafio de trabalhar tensões, transformando-as em instrumento de avaliação e avanço do projeto. O autor identifica um enredo conhecido: demanda excessiva sobre as equipes, superlotação dos serviços, surgimento de novos processos de cronificação de usuários e profissionais e dificuldades gerais de funcionamento das equipes, um sentimento compartilhado de que todos os serviços estariam sendo extremamente exigidos (Bezerra Júnior, 2004).

O tema das relações entre violência e cuidado é apontado como recorrente no contexto dos Caps do Rio de Janeiro, identificando a relevância da questão da violência urbana generalizada e sua progressiva entrada nos espaços e atividades institucionais. Para discuti-la, Bezerra Júnior propõe uma reflexão 
da violência referida aos valores e à estrutura da sociedade em que vivemos: o império do valor econômico, o imperativo do consumo, a lógica do mercado, a perda da crença na história e na ação coletiva, a destruição dos sistemas coletivos doadores de confiança, o culto à satisfação imediata. Propõe, então, uma discussão sobre a cultura que produz a violência e seus efeitos na construção dos laços sociais e na vida subjetiva. Para ele, pensar sobre essa questão, no contexto dos Caps, já não se trata de analisar casos de violência - por mais numerosos que sejam -, mas trata-se, sim, de pensar sobre uma constelação cultural na qual a violência torna-se, cada vez mais, um elemento do cenário, não um episódio, mas uma constante, um estado.

O autor resgata também um aspecto importante no contexto da natureza das práticas nos serviços, ressaltando que qualquer dispositivo de cuidado buscaria não apenas evitar o sofrimento desnecessário, mas também criar espaços de tolerância e modos de acolhimento e convivência com aquilo que, na vida subjetiva, é da ordem "do intratável, do inevitavelmente doloroso, do que não tem remédio nem nunca terá" (Bezerra Júnior, 2004: 6) Enfim, se trabalhamos com a perspectiva de transformação de vidas, essa dimensão não poderia ser esquecida,sobretudo porque os Caps são dispositivos que visam contribuir para que a vida coletiva e as existências individuais sejam mais interessantes, abertas e criativas.

Trabalhos de alguns autores, como Meiguins (2007) e Melman (2007), referentes à área técnica de Cultura de Paz da Secretaria Municipal da Saúde de São Paulo, acenam para a importância de construir um projeto de formação permanente que considere a complexidade dessas questões para a área de saúde, em especial para a capacitação de profissionais envolvidos no cuidado às pessoas em situação de violência. Esses autores identificam a necessidade de conhecimento do universo atual desses profissionais da saúde, suas dificuldades e resistências, e a necessidade de elaboração de estratégias pedagógicas capazes de modificar as representações da violência, desenvolvendo talentos e potencialidades para sustentar o papel de cuidadores. Ressaltam ainda a importância, no contexto da formação permanente, da dimensão de uma construção da cultura de paz - noção referida ao Manifesto 2000 por uma Cultura de Paz e Não Violência, da Unesco - que parte da premissa de que a paz não pode ser cultivada por decreto, e que, embora necessárias, as medidas políticas, econômicas ou militares não seriam suficientes para estabelecê-la. Assim, argumentam que cada indivíduo deveria assumir, na prática, o compromisso com uma cultura de paz por meio dos atos mais simples em sua vida diária. 
Os autores apresentam reflexões importantes sobre o que denominam 'o universo sombrio da violência' e suas relações com o cuidado e os cuidadores. Apontam o despreparo dos serviços e as consequências da violência para os profissionais da saúde, que oscilariam entre uma total impotência e a onipotência heróica de salvar corpos e vidas. Dessa forma, o desafio consistiria em ajudar os profissionais a tomarem para si seu real poder pessoal e profissional.

Segundo os princípios da cultura de paz e da comunicação não violenta, a violência pode ser entendida como expressão trágica da condição humana: o sofrimento, a desigualdade, a injustiça, o desrespeito, a insegurança e o desejo de poder sobre o outro geram violência. Os autores ponderam que os trabalhadores da saúde, mergulhados na cultura da violência e do medo, tenderiam a reproduzir as representações hegemônicas no que diz respeito à violência, e qualquer mudança exigiria um processo lento de intervenções. Defendem, então, a proposta de estratégias ampliadas de formação, que incluiriam espaços de acolhimento, campos de experiência e de reflexão coletiva. Propõem processos de acompanhamento do trabalho dos profissionais e das equipes, ressaltando o caráter complexo desse trabalho, o que exigiria esforço e compromisso de todos os atores envolvidos, incluindo coordenadores e gestores das políticas. Um processo que, necessariamente, deve associar mudanças individuais com transformações do coletivo, apoiadas por uma sólida estrutura organizacional. Destacam o aspecto do sofrimento dos profissionais da saúde, demonstrando como o atendimento que envolve situações de violência pode ser experimentado como uma sobrecarga demasiada, razão pela qual adoeceriam mais. Associam a essa discussão a ideia de que a paz não seria uma conduta passiva, necessitando de condições objetivas e subjetivas para existir. Se, por um lado, a paz nasce dentro de cada pessoa, por outro só é efetivamente construída quando a sociedade garante uma vida com dignidade para todos.

Luzio e L'Abbate (2006), ao resgatar os aspectos históricos e técnico-assistenciais das experiências de São Paulo, Santos e Campinas, tratam de algumas questões importantes a respeito dessa dimensão dos processos coletivos e das relações entre violência e cuidado. Inicialmente, retornando à emblemática experiência de Santos, conduzida, na época, por atores importantes do movimento da reforma sanitária, as autoras descrevem a radicalidade das ações iniciais da intervenção no Hospital Anchieta, que deram origem ao grande projeto de transformação e construção de um novo modelo de cuidado.

A proposta de intervenção em Santos começou com a criação de um conjunto de estratégias de mudanças no ambiente do hospital, visando criar condições 
mínimas de convivência. Para isso, foram tomadas medidas que incluíram a suspensão de toda e qualquer situação ou ato de violência, agressões verbais e físicas, celas fortes, eletrochoques etc. Ao mesmo tempo, foram abertos todos os espaços físicos internos, recuperadas as condições de higiene, alimentação e saúde dos internos, reconstruídas identidades e resgatadas histórias de vida. As autoras ressaltam que esse conjunto de ações continha um significado importante, pois refletia a instauração de uma nova ordem institucional sem violência, com tratamento digno e liberdade.

Kinoshita (1997) e Nicácio (1994) definem a intervenção como a desconstrução de uma "velha ordem", sem modelo a ser seguido, cujo ponto de partida era a necessidade dos usuários. Foram instituídos espaços de convivência, recorrendo-se à grupalidade, às discussões coletivas de necessidades, conflitos, desejos e reinvindicações. Investia-se, assim, na dimensão coletiva, em especial nas assembleias, que tinham o objetivo fundamental de desnudar os papéis codificados, possibilitando aos profissionais e internos a construção de diálogo, reflexões e alternativas para as questões coletivas. Um enfrentamento que, ainda hoje, tomamos aqui como experiência exemplar.

Na experiência de Campinas, as autoras destacam a priorização da responsabilização pelo cuidado e a ampliação da prática clínica, de modo que se alcançasse a dimensão subjetiva e social dos processos de saúde e doença, além do investimento em um sistema de cogestão. Além disso, destacam também o investimento em um sistema de cogestão com forte ênfase nos espaços coletivos, incluindo os conselhos locais de saúde, colegiados de gestão, além de outros dispositivos como oficinas, assembleias com usuários, reuniões por categorias profissionais etc. O objetivo maior seria a gestão cotidiana e democrática na análise de temas e tomadas de decisão envolvendo os diversos atores sociais interessados. Uma valorização dos espaços coletivos que operacionalizavam as diretrizes do governo, fortaleciam os sujeitos e produziam a democracia institucional.

Uma direção que podemos pensar, com as autoras, como um conjunto de estratégias políticas e pedagógicas de fortalecimento dos sujeitos (gestores, trabalhadores e usuários) e espaços coletivos, permitindo a transformação das relações de dominação, criação de novos contratos, composição de consensos, alianças e implantação de projetos. Enfim, as experiências estudadas demonstram os muitos caminhos possíveis para se produzir uma mudança de modelo em saúde mental e, sobretudo, a importância das intervenções e o fortalecimento dos coletivos como alternativa para a sustentação da vitalidade destes e de qualquer transformação que se faça necessária. 
Lancetti (2006) define o trabalho nos Caps como um conjunto de estratégias destinadas a pessoas que não se adaptam aos protocolos clínicos tradicionais, que demandaria um esforço permanente de inovação em tratamentos, muitas vezes, burocratizados, sem descobertas, repetitivos. Ele argumenta que, na prática, há de fato uma tendência à cronificação dos Caps quando criamos coletivos altamente repetitivos, rotinas segmentarizadas e relações muitas vezes infantilizadas. O autor aponta o risco de os profissionais se enclausurarem em diversas formas de corporativismo, trabalhando com recursos reduzidos e repetidos, e propõe como forma de enfrentamento uma ação combinada que inclua estratégias de socialização do conhecimento e de distribuição de saberes para o estabelecimento de uma relação continuada de cuidado.

Um cuidado que, para Boff (2004), exigiria o testemunho e a presença de quem cuida, e - numa referência à relação, desde a etimologia da palavra, entre cuidado e cura - afirma que o humano se definiria justamente pela necessidade de cuidados desde o nascimento até a morte. Partindo da constatação inevitável de que tudo o que existe e vive precisa ser cuidado para continuar a existir e a viver, o autor chama a atenção para o fato de que, no nosso tempo, haveria um abandono da reverência indispensável para se cuidar da vida e de sua fragilidade. E nos leva a pensar uma concepção de cuidado, na qual cuidar, mais do que um ato, é uma atitude - de ocupação, de preocupação, de responsabilização e de envolvimento afetivo com o outro. O que, por sua vez, demandaria uma mudança de concepção na própria formação, que, ao incluir essas questões, possibilita novas práticas e novas relações entre quem cuida e aquele que necessita de cuidados.

O que nos remete à discussão de Merhy (2004), quando este recorre à imagem do "olho do furacão" para designar o lugar de conflitos e desafios em que se encontram os trabalhadores dos serviços substitutivos. O autor fala de problemas atuais, ressaltando a necessidade de o profissional produzir novos coletivos para fora de si mesmo, e do perigo engendrado naquilo que identifica como certezas antimanicomiais. Critica a ideia de que o Caps deve seguir modelos fechados ou receitas, ressaltando a importância da multiplicidade deste de manter um fazer coletivo, solidário e experimental (Merhy, 2004).

$\mathrm{O}$ autor se refere a uma necessidade de fabricação de novos coletivos de trabalhadores de saúde no campo da saúde mental, defendendo que esse trabalho deve ser compreendido como um processo de alta complexidade, múltiplo, interdisciplinar e intersetorial, cujo sucesso dependeria de uma "revolução cultural” no imaginário social, envolvendo os vários sujeitos e atores sociais. 
Ressalta o caráter inovador das práticas, apontando para as necessidades do trabalhador/cuidador, que deve também ser cuidado.

Para isso, Merhy propõe construir espaços de escuta desse exigente fazer cotidiano, no qual os trabalhadores estariam suportando um grande peso, o que os faria experimentar sensações tensas, polares e paradoxais, muitas vezes oscilando entre a potência e a impotência. O autor fala da necessidade de se abrir para escutar essas dificuldades, de gerar processos no cotidiano que exponham essas questões, permitindo que o coletivo as problematize, pense e fale sobre elas. Conclui, afirmando a importância da construção de processos de trabalho que produzam cuidados para os usuários e cuidados para os cuidador.

A tradição basagliana, que queremos tão viva em nossas práticas, concebe a doença mental como uma contradição do homem que pode ser verificada em qualquer tipo de sociedade (Basaglia, 2005) e que faz dela o que mais the convém. Identifica aquilo que denomina a face social da doença, afirmando que esse aspecto será determinante em sua evolução. Para Basaglia,é nesse sentido que se pode falar de uma estreita relação entre psiquiatria e política, entre psiquiatria e ordem pública. Para ele, se é verdade que a política não cura os doentes mentais, por sua vez, o adoecimento e seus códigos interpretativos têm um caráter político preciso.

Passados mais de 30 anos de aprovação da lei italiana de reforma psiquiátrica, neste ano de 2012 em que comemoramos os 11 anos da lei brasileira, retomemos com Basaglia o contexto e o sentido de sua origem:

(...) aquilo que, aos olhos de muitos, parece uma aventura arriscada e cheia de ameaças é somente a inserção, nas normas sanitárias, de um elemento civil e constitucional que deveria estar implícito nelas e não o estava: o reconhecimento dos direitos do homem são e doente. (Basaglia, 2005: 326)

O autor acrescenta que,"embora fruto de uma luta,uma lei pode ser apenas o resultado da racionalização de uma revolta, mas pode também conseguir difundir a mensagem de uma prática,tornando-a patrimônio coletivo" (Basaglia, 2005: 328).

Basaglia afirma ainda que, no contexto dessa prática, a saúde não representa a norma, pois a condição humana é a de estar constantemente entre a saúde e a doença.Afirma isso para enfatizar a importância de, na relação com o paciente, o profissional se colocar diante de um sofrimento que ele deve enfrentar - sem instrumentos, sem defesas - para apreender o mundo de necessidades do qual provém e remetê-lo à história da qual foi banido, no momento mesmo em que foi definido como doença. 
Dessa forma, convida-nos a uma aproximação, a qual caracteriza de forma incisiva:

(...) desarmados como estamos, privados de instrumentos que não sejam uma explícita defesa diante da angústia e do sofrimento, somos obrigados a nos relacionar com essa angústia e esse sofrimento sem objetificá-los automaticamente nos esquemas da doença, e ainda sem dispor de um novo código interpretativo que recriaria a antiga distância entre quem compreende e quem ignora, entre quem sofre e quem assiste. (Basaglia, 2005: 31, grifo do autor)

Assim, recorremos ao pensamento basagliano para, 'desarmados', refletirmos sobre o enfrentamento necessário de uma das faces sociais da doença do nosso tempo - a violência.

\section{Considerações Finais}

O presente trabalho pretende se somar aos esforços de reflexão sobre a construção de novas estratégias para a abordagem da violência nos serviços territoriais de saúde mental e atenção psicossocial. Pretendemos contribuir também para o debate em torno de um trabalho sistemático de fortalecimento dos coletivos e de construção de uma cultura do cuidado que possa vir a se constituir como contraponto e resistência à cultura da violência.

Procuramos, então, identificar aqui alguns pontos de partida para a discussão da vulnerabilidade das nossas instituições de cuidado à violência do entorno - sua linguagem, seus códigos e subprodutos - e sua relação com a fragilidade dos processos coletivos e o relativo abandono, pela equipe do acompanhamento, dos laços afetivos e sociais que se estabelecem a partir da convivência nos espaços coletivos. Isso nos leva a uma necessidade de revisar e repensar o modelo de acolhimento e organização dos Caps, a fim de construirmos estratégias de resistência aos efeitos da complexidade da realidade urbana, da miséria e da violência.

Com base nessa discussão, propomos um certo resgate dos processos coletivos que se constroem nessas instituições, entendendo que valorizar a dimensão coletiva e política das práticas referendaria a perspectiva de entendimento dos Caps como espaços públicos dotados de uma complexidade própria. Ao trazermos o tema dos efeitos da violência nesses espaços coletivos e associá-lo 
à necessidade de criar e sistematizar estratégias de formação e qualificação das equipes, esperamos contribuir para a construção de uma cultura de resistência à violência e banalização da vida, uma perspectiva que se somaria ao conjunto das iniciativas teóricas e práticas fundamentadas na defesa da vida e dos valores que a sustentam.

\section{Referências}

BASAgliA, F Escritos Selecionados em Saúde Mental e Reforma Psiquiátrica. Rio de Janeiro: Garamond, 2005.

BEZERRA JÚNIOR, B. O cuidado nos Caps: os novos desafios. In: ALBUQUERQUE, P. \& LIBÉRIO, M. (Orgs.). O Cuidado em Saúde Mental: ética, clínica e política. Rio de Janeiro: Coordenação de Saúde Mental da Secretaria Municipal de Saúde do Rio de Janeiro, 2004.

BEZERRA JÚNIOR, B. Desafios da reforma psiquiátrica no Brasil. Physis - Revista de Saúde Coletiva, 17(2): 243-250, 2007.

BOFF, L. Saber Cuidar: Ética do Humano - compaixão pela terra. Petrópolis: Editora Vozes, 2004.

CONSELHO REGIONAL DE PSICOLOGIA (CRP/RJ). Direitos Humanos? O Que Temos a Ver com Isso? Rio de Janeiro: CRP-RJ, 2007.

KINOSHITA,R.T. Em busca da cidadania.In:CAMPOS, FC.C.B.\& HENRINQUE, C.M.P.(Orgs.). Contra a Maré à Beira-Mar: a experiência do SUS em Santos. São Paulo:Hucitec, 1997.

LAnCETTI,A. Clínica Peripatética. São Paulo: Hucitec, 2006.

LUZIO, C.A.\& L'ABBATE, S. A reforma psiquiátrica brasileira: aspectos históricos e técnico-assistenciais das experiências de São Paulo, Santos e Campinas. Interface - Comunicação, Saúde e Educação, 10(20): 281-298, jul.-dez. 2006.

MEIGUINS, A. A prática da paz. Revista Tecendo Redes de Paz, 1: 11-13,2007. Disponível em: <http://extranet.saude.prefeitura.sp.gov.br/areas/atencao-basica/cultura-da-paz/ revista-tecendo-redes-de-paz>. Acesso em: 17 nov. 2008.

MELMAN, J. Repensando o cuidado aos cuidadores e transformando as representações da violência. Revista Tecendo Redes de Paz, 1: 11-13,2007.

MELMAN, J. Alguma vez em sua vida, você agrediu alguém que amava? Revista Tecendo Redes de Paz.2007. Disponível em:<http://extranet.saude.prefeitura.sp.gov.br/ areas/atencao-basica/cultura-da-paz/revista-tecendo-redes-de-paz>. Acesso em: 18 nov. 2008. 
MERHY,E.E. Os Caps e seus trabalhadores: no olho do furacão antimanicomial.Alegria e alívio como dispositivos analisadores. 2004. Disponível em: <http://paginas.terra. com.br/saude/merhy/textos/AlegriaeAlivionosCAPS.pdf>. Acesso em: 8 out. 2008.

NICÁCIO, M. F. S. O Processo de Transformação da Saúde Mental em Santos: desconstrução de saberes, instituição e cultura, 1994. Dissertação de Mestrado, São Paulo: Programa de Estudos Pós-Graduados em Ciências Sociais, Pontifícia Universidade Católica de São Paulo. 


\title{
Integralidade e Interdisciplinaridade: o movimento de desconstrução da cultura asilar a partir da experiência do Caps ad de Paracambi
}

\author{
Marise de Leão Ramôa \\ Luiz Carlos Felício \\ Maria Angélica Salgado Ferraz \\ Rodrigo Luiz Lessa
}

O município de Paracambi, considerado por alguns como último município da Baixada Fluminense e por outros como pertencente à região CentroSul, está localizado a aproximadamente $87 \mathrm{Km}$ da capital do estado do Rio de Janeiro. Trata-se de um município que cresceu como Vila Operária e todo o seu desenvolvimento foi marcado pelo crescimento da Companhia Brasil Industrial, fundada em 1874. A emancipação política-econômica-cultural de Paracambi ocorreu em 1960 graças à instalação, em 1954, da Siderúrgica Lanari que na metade do século XX trouxe grande desenvolvimento ao município e mantinha-se como a grande empregadora local.

Se a década de 1960 marca a emancipação de Paracambi, outro fato também torna-se relevante na história dessa cidade, pois em 1963 é fundada a Casa de Saúde Dr. Eiras, com o objetivo de transferir os doentes 'crônicos' da sua matriz, situada na Zona Sul do município do Rio de Janeiro.

A história deste que se tornou o maior hospital psiquiátrico da América Latina se inicia em 24 de agosto de 1943, quando um grupo composto pelos drs. Arnaldo Guinle, Jorge Jabour, Sarmento Barata, Paulo Cesar de Andrade e Leonel Miranda compra a casa de saúde, na qual Leonel Miranda havia estagiado. Com o falecimento ou afastamento dos demais membros da administração, a propriedade e a direção da Casa passam a pertencer unicamente ao dr. Leonel Miranda. Em 1968, o médico, então ministro da Saúde do governo do presidente 
Costa e Silva, idealiza o Plano de Coordenação das Atividades de Proteção e Recuperação da Saúde, conhecido como 'Plano Leonel Miranda':

(...) e se constituiu na mais clara afirmação dos desígnios privatizadores do então governo na área de saúde. (...) Propunha, sem qualquer prurido: a privatização integral do sistema nacional de proteção e recuperação da saúde, regime de livre escolha do médico e do hospital pelo cliente e participação compulsória direta e imediata do usuário no custeio dos serviços. (Mello apud Almeida, 2006: 382)

Em seguida, a Casa de Saúde Dr. Eiras ampliou atendimento, estendendo-se também aos doentes 'crônicos' e 'agudos' da Baixada Fluminense. Tais fatos criaram consequências históricas, produzindo-se uma cultura asilar em tal município, no sentido de uma relação de dependência e da própria população com o hospital, na medida em que era também considerado como grande 'provedor', gerando empregos direta e indiretamente e sendo responsável por cerca de 35\% da arrecadação tributária do município durante o período de intenso movimento. No final da década de 1960 a Casa de Saúde Dr. Eiras já era considerado o maior hospital psiquiátrico da América Latina, e a vida dos munícipes de Paracambi girava em torno dele.

Na década de 1970 surge outro hospital psiquiátrico, o Hospital Paracambi Ltda, com cerca de 150 leitos. A relação de dependência gerava cada vez mais adoecimento e enriquecia-se com a loucura. Em decorrência da falência da Siderúrgica Lanari, inicia-se um ciclo de desemprego. A relação de dependência com os dois hospitais psiquiátricos, fomentada pelo aumento dos índices de pobreza e pela queda do desenvolvimento econômico do país, é marcada pela 'indústria do benefício auxílio-doença' e vai-se fortalecendo na cidade uma cultura asilar e hegemônica de hospitalismo, ainda presente nos dias de hoje.

No início da década de 1990, devido ao trabalho conjunto entre a equipe de saúde mental do município e os profissionais da Casa de Saúde Dr. Eiras, a comunidade começa a refletir de modo crítico a respeito da presença dos manicômios e da precária assistência oferecida aos internos. Tal questionamento, pautado pelos princípios da nova legislação referente à humanização dos hospitais psiquiátricos, inicia um movimento micro e macropolítico, desencadeando a contratação de novos profissionais com especialização em saúde mental pelo Instituto de Psiquiatria da Universidade Federal do Rio de Janeiro (Ipub/UFRJ) e outros pela Fundação Oswaldo Cruz. 
Novos serviços municipais são criados como, por exemplo, o Polo de Saúde Mental, ${ }^{1}$ cuja enfermaria se encontra no Hospital Municipal Adalberto da Graça, caracterizado pelo acolhimento e cuidados diferenciados. As críticas a respeito do antigo modelo manicomial atravessam toda a década de 1990 dando margem à criação de novos serviços nos anos seguintes. Assim, em 2001 é criado o Centro de Atenção Psicossocial Vila Esperança e em 2005 o Caps ad Renascer.

Diferentemente da maioria dos Caps ad do estado do Rio de Janeiro, implantados por pressão da Justiça com o objetivo de gerar leitos de internação para dependentes de drogas, ${ }^{2}$ o Caps ad de Paracambi surge devido ao pedido da população de um bairro do município remetido à Secretaria de Saúde. Tal solicitação foi efetuada devido ao quadro de violência contra jovens. Em 2005, quatro adolescentes envolvidos com o uso indevido e tráfico de drogas morreram (três assassinados e um de overdose). Após o episódio, foi realizada pesquisa junto aos projetos municipais voltados à infância e juventude e foi detectado que em $20 \%$ das famílias havia algum tipo de envolvimento com drogas lícitas e/ou ilícitas.

O empenho da população em solicitar a abertura de um serviço para o tratamento dos usuários de álcool e outras drogas nos mostra um efeito do movimento da reforma psiquiátrica no município. Com o fechamento da Casa de Saúde Dr. Eiras e com os novos serviços que surgiram foi possível mostrar e conscientizar a população de que sempre existem formas diferentes de tratamento que não levam à exclusão social.

\section{Caps Ad Renascer: ${ }^{3}$ dispositivo de saúde}

O Caps ad Renascer foi inaugurado em novembro de 2005. Desde a sua inauguração até hoje já passaram pelo serviço aproximadamente 400 pessoas. Além de atender os munícipes de Paracambi, o Caps também estende o seu atendimento a pessoas provenientes de cidades vizinhas como, Engenheiro Paulo de Frontin, Mendes, Miguel Pereira, Japeri e Seropédica.

Dispositivo público com caráter de triagem e atendimento ambulatorial criado em 1992, após uma série de denúncias sobre as péssimas condições da Casa de Saúde Dr. Eiras.

2 Ver Ramôa (2005).

3 Apesar de outras sugestões da equipe, como Caps ad Lima Barreto ou mesmo Caps ad Paracambi, o nome Renascer foi escolhido pela gestão municipal e traz a representação cultural da droga como elemento de mortificação. 
O Caps ad Renascer recebe pessoas que se apresentam à instituição de forma espontânea ou providas de um encaminhamento, seja ele da esfera jurídica, escolar, social ou mesmo da saúde. Independente da forma como chegam ao Caps ad, as pessoas são recepcionadas nos dias úteis da semana sempre de 9 às 11 horas. Porém, em qualquer outro horário serão acolhidas. Na recepção empreende-se uma anamnese para que toda a equipe possa ter conhecimento do caso recepcionado. É o momento em que se permite à pessoa falar das suas angústias diante dos problemas que a afligem. Em seguida, o usuário é encaminhado para o grupo de acolhimento, que acontece uma vez por semana e é realizado de forma multidisciplinar.

No grupo de acolhimento acontece a apresentação da instituição e uma avaliação por parte de cada usuário sobre o ato de se usar álcool e/ou outras drogas. Tal dispositivo possui caráter informativo onde são salientados os problemas de saúde ocasionados pelo uso abusivo das substâncias psicoativas e são abordados temas que dizem respeito à família, trabalho, vida social, entre outros. A saída do grupo de acolhimento depende da avaliação da equipe multiprofissional, no que tange à construção de demanda de atendimento. A permanência neste grupo pode ser de apenas uma vez ou estender-se a até três, quatro, cinco vezes... O trabalho no grupo de acolhimento leva à elaboração de um projeto terapêutico e, a partir do mesmo, à eleição de um técnico de referência e à marcação de consulta com médico clínico geral ou psiquiatra, quando necessário. O projeto terapêutico atualmente é feito com base nas seguintes atividades: psicoterapia individual, grupo de reflexão, grupo de mulheres, grupo de família, oficina de artesanato (mosaico, pintura, sabão feito com óleo reutilizado, bijuteria), oficina de música, oficina do corpo, acupuntura auricular, educação física, grupo de informação à saúde, acompanhamento medicamentoso, visitas domiciliares, assembleias, atividades extra-Caps. Um dos objetivos principais de todas as atividades é promover uma desalienação do sujeito em relação à droga.

\section{Caps Ad: um dispositivo de rede?}

Após mais de vinte anos do movimento de reforma psiquiátrica e, em meio a dificuldade de diálogo entre profissionais que atendem toxicômanos priorizando a noção de doença orgânica e profissionais que enfatizam a saúde conforme preconizado pela Reforma, assistimos, em 2002, à proposta do Ministério da Saúde de uma política que norteie a prática com dependentes de drogas. 
O Programa Nacional de Atenção Comunitária Integrada a Usuários de Álcool e outras Drogas, que introduz o desenvolvimento dos Caps ad foi pautado no modelo psicossocial devido à sua eficácia comprovada no que se refere à redução de internações (Brasil/MS, 2002: 2). Contudo, é um equívoco pensar que somente a proliferação de novos estabelecimentos especializados dá conta da transformação do cenário assistencial. Esse aprimoramento técnico só tem sentido se for acompanhado de uma ampla revisão do saber que lhe é subjacente. Confundir desospitalização com desinstitucionalização, princípio fundamental do movimento da reforma psiquiátrica, é correr o risco de simplesmente substituir o modelo hospitalocêntrico pelo 'modelo capscêntrico'.

A reforma psiquiátrica é muitas vezes confundida com e reduzida à reforma de serviços. Ainda que, de fato, contemple a humanização do atendimento, bem como o rompimento com a hierarquização dos saberes e com o modelo hospitalocêntrico, entre outras transformações, trata-se, primordialmente, de uma reforma epistemológica do saber médico-psiquiátrico (Amarante, 2001).

Hoje, os serviços oferecidos ao usuário são concebidos sob outro recorte: em consonância com modalidades de serviço que se apoiam na comunidade, toma-se de empréstimo da sociologia urbana a noção de "território" (Santos \& Silveira, 1997) e propõe-se a integração total do usuário de saúde mental à cidade, à sua comunidade de origem, ao bairro onde vivem seus entes mais chegados, para que sinta que conserva suas raízes, que não é o eterno estrangeiro, aquele que, onde quer que esteja, está sempre de passagem.

O termo território passou a ser usado no campo da saúde mental para substituir a noção de base comunitária, pois o comunitário sempre esteve associado à ideia de ações intervencionistas, com a suposta pretensão de prevenção. A construção de um sistema de serviços de base territorial, equivalente ao que vem sendo desenvolvido no atendimento a outros portadores de sofrimento psíquico, pode aumentar significativamente a possibilidade de reintegração do toxicômano na medida em que seus direitos básicos, como autonomia e intimidade, serão mais facilmente preservados, além de aumentar as possibilidades de reconstrução de seus laços afetivos e sociais. O movimento da psiquiatria democrática italiana usa o termo território no sentido de designar o espaço extrainstitucional, entendido como topologia e não como topografia, ou seja, uma 'unidade geográfica de referência' na qual os limites são afetivos, históricos, culturais, socioeconômicos:"(...) limites estreitos de realização de uma cultura que é o 'lugar geométrico das influências' dos diversos moradores, suas histórias, seus antepassados, seus sonhos" (Delgado, 1997: 119). 
A fertilidade da noção de território potencializa a reflexão em torno da reforma psiquiátrica. Ela não apenas propicia o rompimento com a ideia de serviços circunscritos ao eixo hospital-comunidade como dá subsídios importantes para a reflexão de sua dimensão epistemológica.

Pensar num serviço de rede nesta perspectiva exige sintonia com a realidade local, com sua cultura de organização social, bem como uma sociedade civil forte e organizada, capaz de se fazer ativa e participativa diante da administração pública.

O termo rede sugere a ideia de articulação, conexão, vínculos, ações complementares, relações horizontais entre parceiros, interdependência de serviços para garantir a integralidade da atenção aos segmentos sociais vulnerabilizados ou em situação de risco social e pessoal.

Hoje entendemos como maior objetivo da reforma a desterritorialização subjetiva. Guattari e Rolnik consideram que desterritorializar é o mesmo que "abrir-se, engajar-se em linhas de fuga e até sair de seu curso e se destruir" (1986: 323). A subjetividade é vivenciada pelos indivíduos de modo oscilante, entre dois extremos: o da alienação ou o do que chamou de singularização. No primeiro caso, o indivíduo toma para si uma ideologia sem questioná-la, e no segundo consegue estabelecer uma relação de criação com as produções ideológicas.

A desterritorialização subjetiva pode ser contemplada na assistência ao usuário e /ou dependente de drogas a partir do questionamento do profissional quanto à sua clínica, fugindo do especialismo aprisionante das práticas vigentes no atendimento ao toxicômano, na medida em que essas reforçam o lugar instituído de doente, a noção de periculosidade do toxicômano e persistem na concepção moralizante do tratamento. Ou seja, é preciso que a desinstitucionalização da clínica se dê a partir da percepção do profissional de que objetivo se chega com ela: se ela reforça uma identidade rígida ou se promove a desestabilização dessas identidades rígidas, com um consequente movimento de singularização.

Descreveremos então a seguir algumas experiências do Caps ad de Parcambi que produzem movimentos de singularização no campo social, no território de vida dessa cidade.

\section{Enfermeiro e a Desconstrução de um Dado Saber}

Trabalhar em uma equipe interdisciplinar que se destina ao atendimento de pessoas com problemas relacionados ao uso abusivo de álcool e outras 
drogas exige dos profissionais um olhar diferenciado da prática acadêmica tradicional, que privilegia a atuação dos campos de saberes de forma isolada. Nesse sentido, requer ações a serem trabalhadas em conjunto e com o consentimento do usuário e sua família ou responsável.

A prática profissional da enfermagem, a princípio marcada pela ideia de atuação no corpo de um indivíduo, se faz por meio de uma anamnese, a partir da qual são consideradas a presença e a intensidade de algumas características como, por exemplo, déficit no autocuidado; distúrbio no padrão do sono; nível de comunicação afetada; intolerância à atividade; interação social e memória prejudicadas; nutrição alterada; padrões de sexualidade; processos familiares vividos a partir de alcoolismo e/ou uso de outras drogas; risco para lesão ou autolesão e para violência. Porém, com o trabalho interdisciplinar foi possível modificar o foco no indivíduo, no sentido de intervenções no corpo, para se pensar na alteração do 'corpo social', utilizando-se como estratégia a estimulação do usuário quanto a utilizar os recursos que tem em mãos e que o tornarão capaz de elaborar soluções para suas próprias queixas. Fazem parte desses recursos, o Programa de Geração de Trabalho e Renda do município de Paracambi, o Bolsa Família, instituições filantrópicas como a Casa da Luz e cursos oferecidos pela Fundação de Apoio à Escola Técnica do Estado do Rio de Janeiro (Faetec).

Não raro, recebemos usuários apresentando sintomatologia em decorrência de recaídas, fazendo-se necessário prestação de assistência tão logo observado pela equipe. Ao prestar esta assistência, o usuário é conduzido ao leito repouso, mantendo-se isolado de seu grupo, com a finalidade de melhor avaliar o seu quadro. Desse modo, fica impossibilitado de participar de atividades em grupo, visto que, dependendo de cada droga utilizada, a capacidade de compreensão, verbalização, atividade motora, ficam prejudicadas. Caso haja indicação, é realizado o procedimento de desintoxicação.

$\mathrm{Na}$ interação das atividades da enfermagem com as demais categorias profissionais é necessário preparar a reatualização semanal das prescrições médicas em planilhas elaboradas com o objetivo de simplificar a atividade de arrumar e de liberar os pacotes de medicamentos aos usuários; registrar em livro específico (tipo ata) as medicações psicotrópicas dispensadas para controle da entrada e saída de medicamentos; aferir a pressão arterial dos usuários identificando o grupo dos hipertensos anteriormente à realização de práticas desportivas monitoradas pela professora de educação física do Caps ad Renascer. Os hipertensos são encaminhados ao programa de hipertensão realizado 
em parceria com o Programa de Saúde da Família (PSF). Essa atitude reforça o olhar para a saúde da comunidade.

Quando o aparato de suporte do Caps ad torna-se limitado à necessidade do usuário, busca-se o suporte da unidade clínica hospitalar do município, e nos casos de comorbidade essa assistência é realizada pela unidade de urgência psiquiátrica, Polo de Saúde Mental, anexa ao Hospital Municipal Adalberto da Graça, assistindo o usuário em sua integralidade.

\section{A Acupuntura Auricular como Instrumento de Promoção de Integralidade}

A acupuntura auricular é uma técnica oriental que, além de preconizar a necessidade de harmonização entre corpo e mente, visa também à harmonização da função dos órgãos e vísceras por meio de estímulos distribuídos em todo o pavilhão auricular, ou seja, em toda a área da orelha. Não tem por objetivo substituir qualquer terapia convencional e corresponde também a um importante recurso semiológico, uma vez que alterações dos órgãos e vísceras refletem na orelha de diversas formas: ora com alterações na coloração, ora na textura, na sensibilidade, ou até com descamações.

P. M. R., 38 anos, iniciou seu tratamento no Caps ad de Paracambi devido ao uso abusivo de álcool e de maconha. Apresentando-se de forma muito isolada, tímida, não dava credibilidade a esta técnica, preferindo participar das atividades desportivas e de música que eram oferecidas. Sempre que indagado dizia estar tudo bem. Certa vez, após aceitar passar por alguns atendimentos de auriculoterapia, mostrou alterações em cor e sensibilidade na área da próstata. Foi encaminhando para a médica clínica do Caps ad que, após consulta, prontamente solicitou o exame de próstata na rede de saúde. Com os resultados em mãos, foi averiguado que a próstata realmente estava aumentada de tamanho e isso já trazia dificuldades para que a urina fosse expelida durante a micção. De acordo com a médica, se tal fato não tivesse sido visto a tempo, na certa se iniciaria uma infecção urinária. Assim, P. M. R. já estava mais confiante na equipe de profissionais e nos contou das crises renais que acometeram seu pai e um dos irmãos, e nos contou também a respeito do filho que teve um dos rins extirpado quando criança por conta de uma infecção renal. 
Austregésilo (1988) sugere que pais e educadores façam menos discursos verbais e toquem mais os seus adolescentes se têm o real desejo de transmitir algo de valor. Dedicando mais tempo a nós mesmos, aumentando, num primeiro instante, o nosso próprio contato físico, e consequentemente com as pessoas que nos cercam, estaremos intensificando as possibilidades de uma maior compreensão dos problemas e alcançando as soluções com menos dor.

Alves (2006), em seu texto "Integralidade nas políticas de saúde mental", aborda o termo integralidade no contexto dos novos paradigmas da atenção em saúde mental. Para tal, trabalha a natureza do cuidar e com ele traz à tona duas questões: oferta/seleção e inclusão/exclusão. Afirma que a prática usual a ser superada é aquela em que a seleção é o critério básico da oferta dos programas. Entende que a saúde mental é o primeiro campo da medicina em que se trabalha intensiva e obrigatoriamente com a interdisciplinaridade e a intersetorialidade.

Ainda segundo Alves (2006), até a década de 1970 a assistência psiquiátrica tinha como pressupostos o preventivismo e a especialização; de 1970-1980, passam a ser a especialização e a setorização; em 1980 e nos anos seguintes surgem como pressupostos a racionalidade, a regionalização, a hierarquização e a intensidade; a partir da década de 1990, os pressupostos passam a ser o território, a diversificação e a complexidade. Nos anos 2000, temos princípios a inversão de modelo e a cidade saudável, com os serviços atuando mais diretamente na comunidade, como na ação do PSF/Pacs.

As premissas de seleção e consequente exclusão permeiam as políticas para a área de saúde mental, desde a incorporação da loucura como objeto da medicina, no século XVIII, até o início dos anos 90.

A questão da integralidade tem natureza ideológica e técnica. A primeira diz respeito à condenação da segregação, por ferir direitos à convivência e ao livre arbítrio. A segunda, à negação do isolamento como instrumento terapêutico, paradigma essencial à sobrevivência do hospício. A negação do papel do isolamento aliada à compreensão de que o que deve ser cuidado é o sujeito e não a doença enquanto entidade nosológica determina um olhar 'integral' da situação.

Componentes indissociáveis da integralidade são a intersetorialidade e a diversificação. Os Caps ad lidam com problemas complexos e isso exige uma diversificação de ofertas, de maneira integrada, e a busca por parceria com outros setores, para disponibilizar aquilo que muitas vezes a saúde não oferece porque não consegue ou porque não lhe cabe. 
O dispositivo estratégico mais eficiente de substituição do hospital psiquiátrico têm sido os Caps, também chamados de serviços comunitários de saúde mental. Se estes são comunitários, inserem-se em determinada cultura, em território definido, com seus problemas e suas potencialidades.

O Caps ad de Paracambi vêm atuando junto à comunidade local, com trabalhos de promoção da saúde, em articulação com as escolas da rede municipal, onde se discute o lugar da droga no campo histórico, político-social e nega-se a demanda por categorizações nosográficas; nas praças da cidade, no sentido de divulgação do serviço, oferecendo no local oficinas realizadas no Caps ad, como shiatsu, verificação de pressão arterial; na organização de eventos festivos, como o Carnaval, as festas Juninas, o aniversário da cidade, entre outras. O objetivo maior é promover a desconstrução da cultura asilar tão presente no município.

Verificamos, junto a levantamento estatístico de uso de medicamentos psicotrópicos na cidade, que o consumo seria proporcional a um comprimido de Lexotan no mês/ habitante. Devido à constatação, realizamos grupo de desmedicalização, além da divulgação de tal fato junto aos profissionais da rede, pois uma parcela considerável dos usuários do serviço busca o serviço com o objetivo de receber laudos para conseguir benefícios/aposentadorias. Com o desenvolvimento de tal estratégia para enfrentamento do problema, alguns usuários voltaram a trabalhar, promovendo maiores processos de autonomia.

A diversificação de dispositivos é fundamental para se acolher alguém de forma integral, pois com isso reduz-se muito a possibilidade de seleção da clientela. Tivemos dificuldades quanto à aceitação de clientela em situação de rua, pois a mesma chegava construindo uma relação de extremo uso institucional. Por chegarem inúmeras vezes alcoolizados, alguns membros da equipe achavam que os mesmos deveriam ser retirados do local. Fomos trabalhando o quanto tal posicionamento aparentemente técnico estava relacionado à manutenção da exclusão social e que tínhamos que inventar recursos para que tal população pudesse ser assistida. Foi então que o coordenador do serviço fez um trabalho junto com a equipe de abordagem da Secretaria de Ação Social do município, convidando pessoas que estavam em situação de rua para um café da manhã no Caps ad. Nesse dia, os moradores de rua participaram de algumas oficinas como, por exemplo, a oficina de cuidados com o corpo onde tiveram suas unhas cortadas, seus cabelos e barbas aparados, alguns tomaram banho, outros escolheram roupas 'novas' no bazar do Caps ad e participaram de um bate-papo sobre questões ligadas à cidadania. Todos os abordados compareceram e alguns 
mantiveram-se em tratamento. Dois voltaram para casa em outros municípios. Compartilhar saberes é exercício contínuo e exige compromisso social. As principais estratégias para superar o desafio de produzir uma assistência que não promova aprisionamento a saberes rígidos têm sido o oferecimento de cursos no campo da saúde mental, além da supervisão permanente e sistematizada nos Caps. Este capítulo é resultado do efeito do trabalho de supervisão no Caps ad de Paracambi, no sentido da construção de uma intervisão.

A lei 8.080/90, em seu Art.7, \& II, afirma que o SUS deve seguir o referente princípio: "Integralidade da assistência, entendida como conjunto articulado e contínuo das ações e serviços preventivos e curativos, individuais e coletivos, exigidos para cada caso em todos os níveis de complexidade do sistema" (Brasil, 1990: 4).

No dicionário O SUS de A a Z, a integralidade é apresentada como princípio que:

(...) garante ao usuário uma atenção que abrange as ações de promoção, prevenção, tratamento e reabilitação, com garantia de acesso a todos os níveis de complexidade do sistema de saúde. A integralidade também pressupõe a atenção focada no indivíduo, na família e na comunidade (inserção social) e não num recorte de ações ou enfermidades. (Brasil/MS, 2005: 192)

Na prática significa que o usuário sinta-se acolhido, construindo vínculo com os profissionais e com os dispositivos de assistência. A integralidade deverá ser garantida por meio do acesso aos serviços de saúde necessários, que devem ser ofertados em diferentes pontos de atenção à saúde, numa rede horizontalizada.

O movimento da reforma psiquiátrica levou à desconstrução de antigos construtos canônicos da psiquiatria. O modelo hospitalocêntrico e suas práticas degradantes perderam espaço como instrumentos terapêuticos primordiais. Práticas inovadoras foram introduzidas; redes psicossociais de atenção a portadores de sofrimento psíquico vêm sendo construídas na comunidade. Entretanto, essas práticas implicam necessariamente na instauração de uma nova clínica e de uma nova ética?

Essas questões vão se presentificando e nos levam a pensar se houve de fato uma mudança paradigmática sustentando a prática da saúde mental, ou se as mudanças verificadas equivalem mais à adoção da novidade que o novo 'modelo', baseado nas reformas sanitária e psiquiátrica, traz? A simples adoção do 'modelo' não implica a real assimilação do novo saber. Há uma grande diferença entre o profissional que se dá conta do significado de toda a trajetória 
histórica de construção teórica da reforma e os engajamentos sociais, políticos, ideológicos que dela fazem parte e o profissional que simplesmente apropria-se de informações a respeito do que é recomendado pelas atuais políticas de saúde mental transformando-as em uma prática excessivamente técnica e repetitiva.

\section{Considerações Finais}

Atuando no campo da saúde mental, ${ }^{4}$ temos nos preocupado com a prática instituída no tratamento de toxicômanos. Ao longo do tempo, observamos o quanto os profissionais que atuam nessa área apresentam um discurso permeado pela noção de doença. Esse discurso, considerado eficaz, é calcado numa prática universal voltada a dependentes de drogas: os grupos de mútua ajuda e sua consequente institucionalização, na forma do modelo Minnesota. ${ }^{5}$

O fato de o campo de saber médico-psiquiátrico ter-se instituído como próprio ao fenômeno da toxicomania e de até $2002^{6}$ a toxicomania ter-se encontrado relativamente banida dos avanços alcançados nesse campo despertou nosso interesse e curiosidade. Tal como a loucura funda o campo da psiquiatria ao ser instituída como doença mental, a droga, ao ser patologizada, demarca um setor específico do saber médico-psiquiátrico.

A implicação política dos profissionais no que tange ao compromisso com o tratamento dirigido ao toxicômano só ocorrerá se esses profissionais puderem adquirir ampla compreensão do processo de construção dessas práticas como um todo. Caracterizar a toxicomania como doença orgânica (a contribuição dos grupos de mútua ajuda) promove um rompimento com a concepção moral de doença mental, mas mantém uma visão estanque de sujeito, que deixa de ser visto em seus aspectos político-sociais. Se considerada em sua articulação

\footnotetext{
4 "Pelo nome de saúde mental entendemos, aqui, o conjunto de práticas clínicas, políticas e técnicas vinculadas ao campo dos saberes intitulados de psiquiatria e psicanálise na tradição acadêmica. O que está em questão no campo da saúde mental é a problemática do sujeito e da subjetividade nas suas articulações com o social. São as estratégias de subjetivação, assim como os destinos sociais do sujeito, que estão em pauta no campo da saúde mental" (Bezerra Jr. \& Birman, 1990).

5 Tal modelo baseia-se nos 12 passos de Alcoólicos Anônimos e é desenvolvido por equipe multidisciplinar.

6 Ano em que se cria o Programa Nacional de Atenção Comunitária integrada a Usuários de Álcool e Outras Drogas (Brasil/MS, 2002).
} 
com a doença orgânica, caberia à clínica médica assumir o tratamento dessa questão. Contudo, um setor da psiquiatria se apropriou desse saber, baseado na noção de doença, colocando-se em descompasso com o setor da psiquiatria engajado na reforma psiquiátrica que priorizou a desnaturalização da concepção de doença mental, bem como a desconstrução da concepção de cunho moral que atravessa a prática psiquiátrica.

O modelo teórico das ciências naturais encontra-se presente na prática com dependentes de drogas, quando se propõe isolar o sujeito de seu meio para tratar sua doença. Isso se deu no caso da doença mental, pois o isolamento era pensado como estratégia de cura, visto que era preciso conhecer a alienação mental em seu estado puro. O princípio do isolamento era o que sustentava o tratamento moral. Partindo do discurso de causalidade é que se instituiu a prática com dependentes de drogas, olhando para a toxicomania, a partir do modelo infeccioso, segundo o qual a mesma seria consequência da entrada da substância no organismo. Essa visão ainda está muito presente em emergências que se propõem à desintoxicação sem nenhum trabalho posterior e também nas práticas que se baseiam no Modelo Minnesota, no qual o período da internação é chamado de tratamento e o atendimento ambulatorial após alta chama-se pós-tratamento.

Historicamente percebemos uma hegemonia do Modelo Minesotta na década de 1980, em paralelo com o movimento de trabalhadores de saúde mental. Tínhamos, da mesma forma que para os doentes mentais, apenas o modelo de internação em hospital psiquiátrico ou em clínicas particulares especializadas. A formulação de que a dependência de drogas não era uma doença mental e sim uma doença orgânica (ideia de alergia à substância - presente nos grupos de autoajuda) faz com que os dependentes de drogas fiquem sendo vistos como uma específica.

Conforme Amarante (2001) vem pontuando, a proposta de novos serviços como os Caps pretende produzir múltiplas rupturas: com o modelo conceitual/ epistêmico da psiquiatria; com o modelo de doença; com o modelo asilar-manicomial, ou seja, com o isolamento terapêutico e com a ideia do hospital como casa de cura; com o modelo terapêutico médico-psicológico pautado na ideia de cura, normalização; e com o modelo especialístico-profissional. Tais rupturas deveriam promover a construção, invenção de uma nova clínica, partindo de estratégias de cuidado e acolhimento, vendo a terapêutica como construção subjetiva e material de novas possibilidades para os sujeitos, ressignificando conceitos e práticas clínicas e solidificando, novas estratégias de produção de 
subjetividade, que rompam com o lugar social de erro, irresponsabilidade, incapacidade dado tanto ao louco quanto ao toxicômano. Com isso chegaria-se a uma prática baseada nos princípios de inclusão, solidariedade e cidadania, que deram origem ao SUS e que só podem ser efetivados a partir de um processo de desinstitucionalização da clínica, levando-a a se constituir enquanto clínica territorial, no sentido de transformação da realidade local, coletiva e de nova produção de imaginário social.

É isso que tenta promover o Caps ad de Paracambi em articulação com diversos dispositivos dos campos da saúde, educação, trabalho, lazer, etc., num movimento que vai da alienação à autonomia do sujeito, ou seja, que promove separação do outro/ droga para a tomada de um número maior de vínculos, de contratualidades (Tykanori, 1996), ali onde a vida acontece.

\section{Referências}

ALMEIDA, C. Comentário: política e planejamento: o Plano de Saúde Leonel Miranda. Revista de Saúde Pública, 40(3): 381-385, 2006.

ALVES, D. S. Integralidade nas políticas de saúde mental. In: PINHEIRO R. \& MATTOS, R. A. de. Os Sentidos da Integralidade na Atenção e no Cuidado à Saúde. 6. ed. Rio de Janeiro: IMS/Uerj, Cepesc, Abrasco, 2006.

AMARANTE, P. Sobre duas proposições relacionadas à clínica e à reforma psiquiátrica. In: QUINET, A. (Org.). Psicanálise e Psiquiatria: controvérsias e convergências. Rio de Janeiro: Rios Ambiciosos, 2001.

AustRegÉSILO, A. S. B. Curso de Massagem Oriental: a linguagem do tato. São Paulo: Ediouro, 1988.

BEZERRA JR., B. \& BIRMAN, J. Saúde Mental. In: GUIMARÃES, R. \& TAVARES, R. (Orgs). Saúde e Sociedade no Brasil: anos 80. Rio de Janeiro: Relume Dumará, Abrasco, IMS Uerj, 1990.

BRASIL. Lei n. 8.080, de 19 set. 1990. Dispõe sobre as condições para a promoção, proteção e recuperação da saúde, a organização e o funcionamento dos serviços correspondentes e dá outras providências. Brasília, Diârio Oficial da União, 1990.

BRASIL. Ministério da Saúde. Portaria/GM n. 816, de 30 abr. 2002. Brasília, Diário Oficial da União, 2002.

BRASIL. Ministério da Saúde. O SUS de A a Z: garantindo saúde nos municípios. Brasília: Ministério da Saúde, 2005. (Série F. Comunicação e Educação em Saúde) 
DELGADO, P. G. Atendimento psicossocial na metrópole: algumas questões iniciais. Cadernos do Ipub, 14: 113-121, 1997.

GUATTARI, F. \& ROLNIK, S. Micropolítica: cartografias do desejo. Petrópolis:Vozes, 1986. RAMÔA, M. A Acolhida do Desejo: o paradoxo com o modelo asilar, 1995. Monografia do Curso de Especialização em Psiquiatria Social, Rio de Janeiro: Fundação Oswaldo Cruz.

RAMÔA, M. A Desinstitucionalização da Clínica na Reforma Psiquiátrica: um estudo sobre o projeto Caps Ad., 2005. Tese de Doutorado, Rio de Janeiro: Departamento de Psicologia, Pontifícia Universidade Católica do Rio de Janeiro.

TYKANORI, R. Contratualidade e reabilitação psicossocial. In: PITTA, A. (Org.). Reabilitação Psicossocial no Brasil. [s. l.]: Hucitec, 1996. 


\title{
Caps ad de Nova Iguaçu: \\ a história de implantação de uma política de álcool e outras drogas
}

\author{
Simone Pinheiro da Silva \\ Lannia Simão Bellizzi \\ Jurema Alves Pereira \\ Márcia Anselmo Belchior \\ Cristina Maria Douat Loyola
}

O município de Nova Iguaçu faz parte da Região Metropolitana do estado do Rio de Janeiro e é o maior da Baixada Fluminense em área $\left(524,5 \mathrm{~km}^{2}\right)$ e o segundo em número de habitantes, cerca de 900 mil, de acordo com dados do Instituto Brasileiro de Geografia e Estatística (IBGE, 2008).

A cidade está dividida em setores de planejamento integrado (SPIs), cada qual subdividido em unidades regionais de governo (URGs), e estes em bairros. O centro de Nova Iguaçu, principal bairro em termos políticos, econômicos, socioculturais e administrativos, é considerado o segundo polo comercial do Estado e possui os melhores indicadores de qualidade de vida da cidade, além de contar com a maioria dos serviços públicos de saúde, educação e lazer.

A economia do município - é o quarto orçamento do Estado - baseia-se no forte comércio e também na produção agrícola e industrial, sendo um polo da indústria de cosméticos. No entanto, apresenta elevadas taxas de pobreza e violência, especialmente na enorme região periférica. Embora, na última década, Nova Iguaçu tenha conseguido reduzir seu contingente de pobres, a miséria é relevante, como mostra o Mapa do Fim da Fome $2,{ }^{1}$ no qual o município aparece com $26,25 \%$ da sua população abaixo da linha da pobreza.

\footnotetext{
1 Disponível em: <www.fgv.br/cps/MapaFimFomelI/Apresentação/Apresentacao.htm>. Acesso em: 14 nov. 2008.
} 
A rede de saúde pública, como um todo, é insuficiente para atender as demandas. O município possuía, até o início de 2009, 24 unidades básicas de saúde, quatro postos de saúde, um centro municipal de saúde, um centro de saúde do trabalhador, três unidades mistas $(24 \mathrm{~h})$, um hospital geral de referência (Hospital da Posse), 28 unidades do Programa de Saúde da Família (52 equipes) e uma policlínica regional (Kuschimir, 2009).

O processo de implantação do subsistema de saúde mental no município ainda apresenta diversas dificuldades, que acabam por conformar os desafios, os limites e as possibilidades da atenção ao usuário prejudicial e ao dependente de álcool e outras drogas.

Neste capítulo, tentamos esclarecer, sobretudo, a análise de algumas dificuldades enfrentadas, especialmente as políticas, por acharmos serem estas, de certo modo, comuns à maioria dos processos de implantação e de consolidação de serviços dessa natureza.

\section{Dificuldades Gerais}

A primeira dificuldade para a implantação do Centro de Atenção Psicossocial para Usuários de Álcool e Outras Drogas (Caps ad) decorre da instabilidade política perene, coerente com um tipo de relação, comum no Brasil, que associa o antigo patrimonialismo com a feudalização da máquina administrativa, resultante da negociação dos cargos públicos, transformados em moeda de troca político-partidária (Moreira, 2005).

Um dos inconvenientes da restrição da atuação da secretaria foi, obviamente, a descontinuidade nos processos de formulação e implantação de políticas públicas na área da saúde como um todo, o que não poupou o Sistema Único de Saúde (SUS), cuja implantação no município foi realizada/se deu de maneira sui generis, ferindo todos os aspectos de uma política de proteção social, entendida esta como um direito inerente à cidadania e determinante para a reprodução dos indivíduos e das coletividades. É de relevância especial o fato de esta implantação não ter obedecido às noções básicas de equidade no acesso e na utilização dos serviços como usufruto de um direito constitucional.

Em particular, para o que nos interessa aqui, houve um atraso importante na introdução da política de saúde mental como pauta de governo. Somente a partir de 2006, iniciou-se uma peculiar descentralização do sistema de saúde 
mental, que contava, há tempos, com apenas um Caps II adulto e um ambulatório de psiquiatria (em uma cidade, voltamos a lembrar, com quase um milhão de habitantes). Transcorridos esses anos, e embora a cidade tenha, por um motivo ou outro, se esforçado para implantar os serviços previstos na portaria $\mathrm{n}$. 336/GM (Brasil/MS, 2004), do Ministério da Saúde, ou seja, um sistema de saúde mental com desenho estendido - Caps III, um Caps ad, um Centro de Atenção Psicossocial Infanto-Juvenil (Capsi), duas emergências psiquiátricas, três residências terapêuticas e uma rede de ambulatórios -, nenhum dos serviços, até meados de 2009, estava credenciado na Secretaria de Estado de Saúde e Direitos Humanos do Rio de Janeiro (SESDH).

A incapacidade para credenciar as unidades implantadas configura a segunda dificuldade, diretamente ligada à falta de planejamento na implementação dos serviços, que se expressa dramaticamente pelo déficit de custeio, já que o município recebe, para sustentar sua rede de saúde mental, um numerário muito inferior ao necessário. Além disso, toda a rede de saúde mental foi implantada na região central do município, abandonando a distante periferia, que, no entanto, concentra a maioria da população usuária do SUS. Desse modo, apesar da ampliação do número de serviços, o fato de nenhuma unidade estar credenciada compromete a efetividade do programa, levando a um estrangulamento no financiamento que poderia ser evitado, uma vez que o sistema de saúde mental é capaz de minimizar os gastos de custeio graças às contrapartidas garantidas pelas outras instâncias de governo.

A terceira dificuldade decorre, diretamente, da forma atípica de implantação dos serviços. A chamada 'descentralização' do programa de saúde mental, antes 'centralizado' em um único Caps II, resultou, na verdade, em uma 'hipercentralização' dos serviços. Ignorando-se o princípio da acessibilidade e o conceito de territorialidade, a maioria dos serviços ficou concentrada no centro da cidade, o que dificultou o acesso da maior parte da população, que, sem alternativa, mesmo com mais ofertas de serviços, continuou a procurar assistência nos municípios limítrofes.

Uma quarta dificuldade é inerente às lacunas existentes de capacitação profissional na saúde mental, como um todo, não apenas em Nova Iguaçu, que fez surgir distorções graves. No entanto, buscamos garantir um processo de capacitação continuada com a equipe do Caps ad de Nova Iguaçu por meio das supervisões sistemáticas com estudo de casos, participação nos fóruns municipais e estaduais de saúde mental, capacitação dos integrantes da equipe através 
de cursos à distância promovidos pela Secretaria Nacional de Políticas sobre Drogas (Senad), participação da equipe no curso de atualização em álcool e outras drogas oferecido pela Escola Politécnica de Saúde Joaquim Venâncio da Fundação Oswaldo Cruz (EPSJV/Fiocruz) e organização, pela equipe, de um fórum intermunicipal para troca de experiências na assistência a usuários de álcool e outras drogas.

Em meados de 2009, a equipe do Caps ad Vanderlei Marins, observando algumas intercorrências, percebeu a necessidade de planejar uma capacitação para profissionais de outros dispositivos assistenciais da rede de saúde, em especial do Programa Saúde da Família (PSF), e organizou o Treinamento e Capacitação Multiprofissional na Assistência a Usuários de Álcool e Outras Drogas para profissionais da Saúde Mental e Atenção Básica. Devido aos limites institucionais, não foi possível avançar, a partir deste treinamento, ao encontro de uma perspectiva mais ampla de alcance transdisciplinar. Porém, avaliamos que houve um esforço importante da equipe nesta direção, constatado por meio de relatos dos participantes (principalmente dos agentes comunitários de saúde), que apontaram para uma reflexão acerca da atenção a usuários de álcool e outras drogas, através de trocas de saberes e práticas entre os profissionais do Caps ad integrados com as equipes de saúde da família.

A parceria PSF e saúde mental não quer dizer treinamento das equipes de saúde da família em procedimentos simplificados de psiquiatria. Requer, sobretudo, uma construção recíproca e responsável de uma teoria, de uma prática e de uma ética, mediante o estabelecimento de um acordo político. Saúde mental e PSF implicam transformações profundas nas práticas do Estado, em todos os seus níveis (Hirdes, 2009).

Em 2009, a 'nova política' de mais uma nova gestão na saúde tornou especialmente caótica uma situação já calamitosa, ao estabelecer um processo de tomada de decisões gerenciais com base nas relações entre evidência e contexto. A secretaria de saúde, na esperança de suprir com profissionais concursados o sistema, para dessa forma fortalecer a burocracia racional-legal, foi negligente, 'esquecendo-se' de tornar atrativo o salário do funcionalismo de nível superior, ao mesmo tempo que não se preocupou com o reajuste do defasado salário dos contratados. O resultado foi que o município não conseguiu preencher nem 10\% das vagas existentes para psiquiatras, além de ter perdido os antigos médicos contratados, que se demitiram em massa. Assim, os serviços de saúde mental do município - em especial as emergências, o Capsi e o Caps ad - ficaram desassistidos de médicos, ocasionando atendimentos inadequados e perigosamente 
precários. A desconsideração do contexto como condicionante para as tomadas de decisões gerenciais precipitou, por fim, não apenas a inédita paralisação dos serviços de saúde mental, mas também uma explosão de denúncias contra praticamente todas as unidades de saúde municipais, levando a que alguns dos gestores tivessem que se explicar (provavelmente sem sucesso) na câmara de vereadores do município.

O resultado dramático de todas essas dificuldades, para o Programa de Saúde Mental do município, foi uma forma de aggiornamento, que não se fez apartado da tradição estratégica do conservadorismo, o qual, travestido por uma linguagem supostamente progressista, impõe discursos unicausais, cujo maniqueísmo notadamente impede o exercício de qualquer problematização, o que acaba dando munição para as palavras de ordem contrarreformistas que clamam por mais hospícios.

\section{Desafios Particulares}

O primeiro desafio para a constituição do Caps ad foi, então, políticoinstitucional. Como modo de enfrentamento, buscou-se, na territorialidade de utentes, familiares e amigos, o acúmulo de capital político e social que compensasse as dificuldades de uma política de saúde fragilizada pela descontinuidade político-administrativa.

Assim, a equipe de saúde mental responsável pelos atendimentos de usuários de álcool e outras drogas passou a ter, como estratégia de luta, o hábito de se fazer representar em grande parte dos espaços públicos disponibilizados, seja na cidade, seja fora dela. Como ponto de partida, a partir de 2003, a equipe torna constante sua participação nos fóruns de discussão sobre álcool e outras drogas patrocinados pelo setor saúde do estado do Rio de Janeiro. Esses encontros tinham o objetivo de possibilitar a interlocução entre os municípios, instituições e outros atores da sociedade, por meio de apresentações, debates, estudos e orientações da assessoria do estado responsável por essa área.

Ainda como parte da estratégia situacional para facilitar as ações de implantação do Caps ad, podemos relatar a participação da equipe nas reuniões do Conselho de Prevenção ao Uso Indevido de Álcool e Outras Drogas; apresentação do projeto de criação do Caps ad no Conselho Municipal de Saúde, que foi aprovado e inscrito em ata; participação na III Conferência 
Municipal de Prevenção ao Uso Indevido de Álcool e Outras Drogas, onde a equipe apresentou um trabalho intitulado Redução de Danos e também apresentou o projeto do Caps ad; participação no projeto "Música: Tô dentro, Drogas: Tô fora" - realizado na praça de skate de Nova Iguaçu e organizado pela parceria das secretarias de Educação, Saúde, Cultura e Comunicação Social -, que contou com shows de música, dança e malabaristas, além da distribuição de preservativos e folders contendo orientações sobre álcool e outras drogas.

Outra estratégia empregada derivou das dificuldades referentes à aquisição de dados confiáveis sobre a população usuária de drogas do município para a avaliação epidemiológica do uso prejudicial e da dependência. Um levantamento estatístico realizado no Setor de Acolhimento à Crise da Coordenação de Saúde Mental, entre novembro de 2004 e maio de 2005, revelou apenas 68 casos em situação de uso problemático de substâncias estimulantes e/ou entorpecentes. A hipótese imediata para se explicar um número tão baixo de incidência, em uma cidade tão populosa, coadunou-se com um alarmante subdiagnóstico.

Foi reconhecendo a existência de uma equipe empenhada, dinâmica, motivada e presente, sempre próxima à população demandante de assistência, e reconhecendo também a existência dessa clientela em situação de uso abusivo de álcool e outras drogas com demanda reprimida, que alguns atores do campo da saúde mental do município, baseando-se na portaria n. 336/GM, de 19 de fevereiro de 2002 (Brasil/MS, 2004), colocaram na agenda política a implantação de um dispositivo específico, o Caps ad.

Após a implantação do serviço, perdurou ainda um segundo desafio, referente às dificuldades para o credenciamento da população necessitada de ajuda. Após dois anos da implantação e início do funcionamento, o déficit no custeio comprometeu a manutenção integral da equipe e tornou o dia a dia do serviço carente de um fluxo contínuo e regular de insumos e materiais, incluindo a falta de medicamentos essenciais.

O terceiro desafio, técnico-filosófico, foi responsável por algumas distorções, não apenas nas práticas cotidianas, mas na composição técnica da equipe e, especialmente, nas relações de colaboração e complementaridade, que se perderam em grande parte e, em determinado momento, deixaram de apresentar qualquer possibilidade de concertação. ${ }^{2}$ Essa questão resultou no apareci-

2 Concertação significa buscar posições pactuadas que possam ser majoritárias e também hegemônicas, sem, contudo, se constituir como uma síntese na qual os termos deixem de manter 
mento de resistências e disputas entre uma visão interdisciplinar e outra, de caráter conservador e unicausal, tendente, no caso, ao psicanalismo e ao psicologismo, como também tem sido comum no histórico recente de implantação de outros Caps ad pelo Brasil.

\section{Possibilidades: aspectos gerais da assistência e funcionamento}

O Caps ad configurou-se como um serviço destinado a oferecer assistência em atenção diária a usuários de álcool e/ou outras drogas. Funciona, atualmente, em um espaço físico composto de uma sala com dois leitos para repouso, uma varanda com espaço para convivência e recepção, uma sala onde são realizadas as oficinas terapêuticas, duas salas para atendimento individual, grupos e oficinas e uma sala onde funciona a administração.

A porta de entrada é realizada pela própria equipe, que recebe casos encaminhados por outras instituições, bem como os casos de demanda espontânea. $\mathrm{O}$ acolhimento é realizado diariamente por uma equipe interdisciplinar composta por psicólogos, psiquiatras, médicos clínicos gerais, enfermeiros, assistentes sociais, terapeutas ocupacionais, arte-educadores, musicoterapeutas, monitores, técnicos administrativos, técnicos de enfermagem, auxiliares de serviços gerais, recepcionistas, vigias, supervisoras e coordenadoras. O centro oferece um espaço de atendimento diário aos utentes, objetivando sua reintegração na família, na sociedade e no trabalho, de forma gradativa, contribuindo para o fortalecimento de vínculos afetivos e o enriquecimento da autoestima, com base em um planejamento terapêutico individualizado, lazer e apoio para o exercício dos direitos civis e sociais.

Prestando atendimento nas modalidades intensiva, semi-intensiva e não intensiva, a equipe procura realizar o planejamento terapêutico dentro de uma perspectiva individualizada de evolução contínua por meio de atividades coletivas, utilizando o princípio de uma lógica ampliada de redução de danos na construção e execução de planos e ações de cuidado às consequências danosas decorrentes do uso e abuso de drogas.

A equipe aceita, como sugere a Harm Reduction Coalition, que "bem ou mal, as drogas ilícitas fazem parte deste mundo e escolhe trabalhar para mini-

entre si certa resistência e independência. 
mizar seus efeitos danosos ao invés de simplesmente ignorá-los ou condenálos". ${ }^{3}$ Da mesma forma, admite que as drogas lícitas sejam o principal problema de saúde pública relacionado à toxicodependência e procura desenvolver um projeto de prevenção que inclui o uso responsável dessas substâncias, tal qual sugerem as investidas do Ministério da Saúde contra o uso deletério do tabaco e do álcool. É realizado, então, um pacto com o utente para o cumprimento de determinadas regras, sempre em acordo com suas necessidades e possibilidades, que, paulatinamente, podem significar desde um uso quase moderado até a abstinência total. Não se considera a abstinência total um estágio necessário, mas um horizonte na direção do qual um caminho deve ser gradativamente construído e conquistado, dependendo da situação.

É também estimulada a construção, pelo utente e seus familiares, de uma rede de apoio e proteção, que inclui a utilização dos equipamentos públicos e privados disponíveis no território. Da mesma forma, estimula-se também a capacidade do autocuidado e da problematização de objetivos vitais voltados para a própria satisfação pessoal do utente, na medida em que se admite serem as drogas, em princípio, um prazer, mesmo que sejam um prazer fácil ou um prazer derivado da anestesia tanto física quanto psicológica ou moral. Abandonar esse prazer deve corresponder a objetivos cuja satisfação seja a menos abstrata possível e a mais próxima daquilo que podemos admitir como um afeto para o utente. Essa construção é, portanto, corresponsável, e suas estratégias necessariamente devem contar com a participação ativa e motivada do utente.

A equipe técnica elabora o projeto terapêutico de forma individualizada, respeitando cada subjetividade, o que inclui a territorialidade e o(s) tipo(s) de droga(s) que tenha(m) se tornado problemático(s). O ambiente é preparado para se tornar acolhedor e, assim, favorecer as questões terapêuticas e facilitar ao máximo a adesão ao tratamento, possibilitando a construção, como já mencionado, corresponsável (entre equipe e utente) das estratégias para o enfrentamento dos agravos que surgem com o uso abusivo e/ou patológico do álcool e outras drogas.

Como em qualquer outro Caps, a pretensão é construir articulações consistentes não apenas com a rede de saúde, mas também com diversos outros setores da administração pública, sobretudo com os responsáveis pela promoção social, justiça, educação, trabalho, cultura, esporte e lazer, para que estes tenham a oportunidade de entender o tratamento, oferecê-lo e servir de suporte

3 Disponível em:<www.harmreduction.org/>. Acesso em: 8 nov. 2003. 
para ele, em conformidade com os princípios da reforma psiquiátrica e a promoção e defesa da cidadania.

No Quadro 1, podemos observar os tipos de atendimento oferecidos pelo Caps ad.

Quadro 1 - Especificações sobre os tipos de atendimento ofertados

\begin{tabular}{|c|c|c|c|}
\hline $\begin{array}{l}\text { Tipos de } \\
\text { atendimento }\end{array}$ & Especificação & Objetivos & Mini-equipe \\
\hline \multirow{3}{*}{ Grupal } & $\begin{array}{l}\text { Grupo } \\
\text { terapêutico }\end{array}$ & $\begin{array}{l}\text { - Ter espaço garantido de escuta, } \\
\text { apoio e orientação. } \\
\text { - Compartilhar suas experiências, } \\
\text { participando ativamente de um } \\
\text { movimento de reflexão. }\end{array}$ & $\begin{array}{l}\text { Psicólogos, } \\
\text { terapeuta } \\
\text { ocupacional, } \\
\text { técnica de } \\
\text { enfermagem, } \\
\text { psiquiatra, } \\
\text { monitor. }\end{array}$ \\
\hline & $\begin{array}{l}\text { Grupo de } \\
\text { recepção }\end{array}$ & $\begin{array}{l}\text { - Disponibilizar um espaço } \\
\text { onde é explicitada a forma de } \\
\text { acompanhamento oferecido pelo } \\
\text { Caps ad, sanando dúvidas. } \\
\text { - Avaliar as demandas e expectativas } \\
\text { de cada utente, oportunizando o } \\
\text { contato com outros utentes e com } \\
\text { profissionais que poderão observar } \\
\text { outras questões, para garantir um } \\
\text { projeto terapêutico mais condizente } \\
\text { com as especificidades do utente. }\end{array}$ & $\begin{array}{l}\text { Psicólogos, } \\
\text { assistente } \\
\text { social, terapeuta } \\
\text { ocupacional, } \\
\text { técnica de } \\
\text { enfermagem, } \\
\text { psiquiatra, } \\
\text { monitor. }\end{array}$ \\
\hline & $\begin{array}{l}\text { Grupo de } \\
\text { saúde }\end{array}$ & $\begin{array}{l}\text { - Oferecer atividades recreativas } \\
\text { e esportivas com o objetivo } \\
\text { de inclusão, socialização e } \\
\text { desenvolvimento da coordenação } \\
\text { motora. } \\
\text { - Desenvolver o gosto por uma } \\
\text { atividade saudável. } \\
\text { - Diminuir a ansiedade. } \\
\text { - Oferecer informações sobre } \\
\text { atualidades na área de saúde que } \\
\text { possam ser utilizadas no dia a dia } \\
\text { de cada utente, tendo como foco } \\
\text { principal a promoção da saúde e a } \\
\text { prevenção de agravos. }\end{array}$ & $\begin{array}{l}\text { Clínico geral, } \\
\text { enfermeira e } \\
\text { monitor. }\end{array}$ \\
\hline
\end{tabular}


Quadro 1- Especificações sobre os tipos de atendimento ofertados (cont.)

\begin{tabular}{|c|c|c|c|}
\hline $\begin{array}{l}\text { Tipos de } \\
\text { atendimento }\end{array}$ & Especificação & Objetivos & Mini-equipe \\
\hline Grupal & $\begin{array}{l}\text { Oficinas } \\
\text { expressivas } \\
\text { e de geração } \\
\text { de trabalho e } \\
\text { renda }\end{array}$ & $\begin{array}{l}\text { - Oportunizar a expressão dos } \\
\text { sentimentos por meio da arte e da } \\
\text { música, favorecendo o tratamento } \\
\text { e a descoberta de habilidades. } \\
\text { - Favorecer a emancipação } \\
\text { e autonomia dos utentes, } \\
\text { conduzindo-os ao trabalho e ao } \\
\text { gerenciamento da própria vida. }\end{array}$ & $\begin{array}{l}\text { Arte-educadora, } \\
\text { terapeuta } \\
\text { ocupacional e } \\
\text { técnica de } \\
\text { enfermagem. }\end{array}$ \\
\hline \multirow[t]{2}{*}{ Individual } & Acolhimento & $\begin{array}{l}\text { Proporcionar escuta atenciosa - } \\
\text { acolhendo o sujeito que busca o } \\
\text { serviço, promovendo um espaço } \\
\text { de interação e oportunizando a } \\
\text { construção de uma relação de } \\
\text { confiança, em que o profissional } \\
\text { busque conhecer a história do uso de } \\
\text { drogas e suas repercussões na vida } \\
\text { do utente - assim como identificar as } \\
\text { possíveis demandas de tratamento } \\
\text { que são levadas à equipe. }\end{array}$ & Toda a equipe \\
\hline & $\begin{array}{l}\text { Atendimento } \\
\text { individual }\end{array}$ & $\begin{array}{l}\text { Proporcionar um espaço onde se } \\
\text { permite ao utente criar uma relação } \\
\text { de confiança, possibilitando, assim, o } \\
\text { início do processo terapêutico. }\end{array}$ & Toda a equipe \\
\hline $\begin{array}{l}\text { Suporte } \\
\text { social }\end{array}$ & $\begin{array}{l}\text { Orientações } \\
\text { sobre: } \\
\text { - Direitos dos } \\
\text { usuários } \\
\text { - Previdência } \\
\text { social e } \\
\text { outros } \\
\text { - Assembleia }\end{array}$ & $\begin{array}{l}\text { - Favorecer a emancipação dos } \\
\text { utentes, conduzindo-os ao } \\
\text { gerenciamento da própria vida. } \\
\text { - Local de discussão da vida em } \\
\text { coletivo, dos direitos e deveres, } \\
\text { ocupação dos espaços etc. }\end{array}$ & Assistente social \\
\hline Outras ações & $\begin{array}{l}\text { Passeios, } \\
\text { visitas } \\
\text { culturais } \\
\text { e festas } \\
\text { de época } \\
\text { (Natal, Festas } \\
\text { Juninas, } \\
\text { Páscoa etc). }\end{array}$ & $\begin{array}{l}\text { - Proporcionar lazer. } \\
\text { - Favorecer a emancipação e } \\
\text { autonomia. } \\
\text { - Favorecer o vínculo profissional/ } \\
\text { utente. } \\
\text { - Trabalhar o processo de convívio } \\
\text { inter e intragrupal. } \\
\text { - Encorajar e proporcionar novas } \\
\text { experiências. }\end{array}$ & Toda a equipe \\
\hline
\end{tabular}




\section{Dilemas}

Algumas questões que permeiam o cotidiano do Caps ad levam a acreditar que as soluções apenas serão encontradas, lenta e territorialmente, à medida que se consolidem as formas de atuação, interdisciplinar e intersetorial, em cada situação. Portanto, torna-se importante listar alguns dilemas próprios da equipe do Caps ad de Nova Iguaçu.

Mesmo que essas questões signifiquem uma parcialidade própria do estágio em que se encontra essa equipe, devemos lembrar que os serviços territorializados necessariamente devem conter traços identitários característicos da cultura na qual foram implantados.

Se a lógica ampliada da redução de danos não proscreve a abstinência total como modus operandi possível na assistência, em que momento torná-la efetiva: como horizonte desde sempre determinado ou como prescrição apenas diante de uma situação-limite?

Se a redução de danos motiva o conhecimento do uso 'adequado' (não nocivo) de drogas, como viabilizar esses ensinamentos em um contexto políticojurídico proibicionista, que investe maciçamente nas ações de redução de oferta e demanda e que torna as drogas, por si mesmas, um mal, abstraindo-as das relações que lhes conferem o sentido bom ou ruim? Esse contexto não torna impossível - salvo por transgressão à lei e às crenças nele embutidos - qualquer atitude que signifique um uso 'adequado'?

É possível justificar eticamente a redução de danos (como flexibilidade estratégica das ações) em casos extremos, de vida ou morte, nos quais a abstinência total significa a única alternativa não paliativa? Ou melhor, havendo uma alternativa evidente não paliativa, é justo e eticamente aceitável não torná-la imperativa e medida imediata diante de uma situação-limite?

Como lidar com os utentes que chegam muito alcoolizados/drogados ou que saem para se drogar e ainda levam um colega utente do Caps, mesmo dentro das diretrizes flexíveis da redução de danos? Quais os limites dessa flexibilidade?

Sobre as dificuldades de se manter acolhimento diário diante de uma demanda sempre crescente, pergunta-se: é mais importante acolher todo o universo demandado ou garantir a resolutividade para quem já está inserido no serviço, negando, assim, novos casos que extrapolariam a capacidade de resolução do serviço?

Como fazer o serviço tender para a atenção interdisciplinar e evitar o aprisionamento dos papéis profissionais: médicos com consultas individuais 
para medicar; psicólogos e psicanalistas querendo atender individualmente; enfermeiras e assistentes sociais com dificuldade em colocar limites nos acolhimentos?

A identificação da comorbidade diagnóstica para o melhor atendimento no Caps ad implica maior governabilidade sobre a demanda clínica desses utentes ou basta a articulação com a rede?

Como lidar com a realidade sedutora de um contexto conflagrado, social e economicamente iníquo, no qual o uso de mediadores químicos na vida cotidiana é quase uma regra da arte da sobrevivência?

O jogo patológico pode ser inserido na dinâmica ampliada da redução de danos? Como?

Todas essas questões ainda aguardam por respostas mais enfáticas.

\section{Conclusão}

O acesso ao cuidado em saúde mental configura-se como um problema no âmbito do SUS, sendo a rede de atenção dessa área um desafio em face de um cenário de injustiça, iniquidade e exclusão social. Entende-se que a política a ser definida deve efetivar ou viabilizar acesso aos serviços de saúde. Assim, ampliar os serviços em saúde mental significa reconhecer o direito constitucional da população à saúde, embora essa ampliação não baste, pura e simplesmente, já que, sem uma estratégia de implantação baseada nos princípios da reforma sanitária e psiquiátrica e sem equipes devidamente capacitadas para a realização desses serviços, o que se consegue é apenas uma espécie de aggiornamento da desassistência.

Acreditamos que a responsabilidade pela implementação de políticas públicas de saúde na área de saúde mental é também da equipe multiprofissional, dos utentes e da sociedade civil, além dos próprios gestores. Assim, faz-se necessário o investimento em uma perspectiva crítica, que investigue profundamente os acontecimentos reais, com suas consequências agradáveis ou não, e imperiosa, para que se possa, quem sabe em um futuro não muito distante, tornar os princípios e as diretrizes básicas do SUS, incluindo a lei antimanicomial, pressupostos de todos os serviços públicos de saúde. 


\section{Referências}

BRASIL. Ministério da Saúde. Secretaria-Executiva. Secretaria de Atenção à Saúde. Legislação em Saúde Mental: 1990-2004. 5. ed. ampl. Brasília: Ministério da Saúde, 2004. FOUCAULT, M. História da Sexualidade I: a vontade de saber. Rio de Janeiro: Graal, 1985.

HIRDES, A. A reforma psiquiátrica no Brasil: uma (re)visão. Ciência \& Saúde Coletiva, 14 (1): 297-305, jan.-fev. 2009.

KUSCHIMIR, R. (Coord.). Atlas de Serviços de Saúde do Estado do Rio de Janeiro. Rio de Janeiro: Fiocruz, Secretaria Estadual de Saúde e Defesa Civil-RJ, 2009.

MOREIRA, J. B. G. Direito Administrativo: da rigidez autoritária para a flexibilidade democrática. Belo Horizonte: Fórum, 2005. 


\title{
Anexo
}

\section{Instrumento Interdisciplinar para Diagnóstico e Registro Epidemiológico em Caps ad}

\author{
Sergio Alarcon \\ Jupiara dos Santos \\ Fabiola Espolador Ramalho \\ Márcia Anselmo Belchior \\ Jurema Alves Pereira \\ Simone Pinheiro da Silva \\ Lannia Simão Bellizzi \\ Cristina Maria Douat Loyola
}

É apresentada aqui a sugestão de um instrumento diagnóstico interdisciplinar. Não se trata de um recurso esgotante, nem de uma referência necessária para as atividades de todos os serviços, mas de uma tentativa de mostrar que o diagnóstico do uso prejudicial de álcool e outras drogas não pode se basear apenas em observações fragmentadas, conforme cada especialidade e profissão envolvida na atenção, sem que se observe uma totalização direcionada à territorialidade do utente.

O instrumento valoriza os aspectos descritivos e quantitativos, facilitando, ao máximo, a compreensão e a aplicação das perguntas pela equipe. Contudo, é com base no resultado da discussão das respostas obtidas que se formarão os indicadores qualitativos (baseados na melhoria da qualidade de vida) ${ }^{1}$ constituintes do diagnóstico interdisciplinar, necessariamente complexo e direcionado para a reconstituição aproximada de uma biografia, e não apenas para a determinação de uma nomenclatura nosológica.

Trata-se, além disso, de uma referência para a manutenção, em grau elevado, da participação e do interesse da equipe, que confere um papel ativo e democrático - diríamos transversal - a todos os trabalhadores da saúde mental

\footnotetext{
Podemos citar como indicadores o acesso a trabalho e renda dignos; a níveis compatíveis de educação; à saúde, cultura, habitação, mobilidade; a espaços de convivência social etc.
} 
na elaboração e consolidação do projeto terapêutico, e da posterior construção de indicadores para a avaliação dos processos utilizados e dos resultados alcançados.

O questionário de diagnóstico proposto consta de onze partes - identificação; história social; história da doença atual; história patológica pregressa; exame clínico geral; exame físico; exame psíquico; áreas de interesses e habilidades; história sexual; hipóteses diagnósticas; conduta e observações - apresentadas a seguir.

\section{Identificação}

Registro realizado por:

Data:

Nome:

Data de nascimento:

Idade: anos.

Sexo: ( ) feminino ( ) masculino. Cor:

Naturalidade: Nacionalidade:

Endereço:

Bairro:

Estado: Município: CEP.

Ponto de referência:

Telefone: Telefone para recados:

\section{Documentação:}

Identidade: . CPF: CTPS:

\section{Filiação:}

Nome do pai:

Nome da mãe: 


\section{História Social}

Profissão:

Situação atual: ( ) ativo; ( ) em benefício; ( ) aposentado; ( ) desempregado

Carteira de trabalho assinada? ( ) sim ( ) não. Há quanto tempo:

Escolaridade:

( ) analfabeto

( ) $1^{\circ}$ Grau completo

( ) $2^{\circ}$ grau completo

( ) superior completo

( ) $1^{\circ}$ grau incompleto

( ) $2^{\circ}$ Grau incompleto

( ) superior incompleto

( ) pós-graduado

Frequenta escola? ( ) Não ( ) Sim. Qual?

Estado Civil:

( ) solteiro(a)

( ) separado/ divorciado/ já viveu maritalmente

( ) $\operatorname{casado}(\mathrm{a}) /$ vive maritalmente

( ) viúvo(a)

Renda:

( ) menos de um salário mínimo

( ) 3 salários mínimos

( ) 1 salário mínimo

( ) 4 ou mais salários mínimos

( ) 2 salários mínimos

Participa de alguma religião? ( ) não ( ) sim. Qual?

Por quê?

Tem filhos? ( ) não ( ) sim. Quantos?

Idade e sexo dos filhos:

Tem irmãos? ( ) não ( ) sim. Quantos?

Idade e sexo dos irmãos:

Condições de moradia: ( ) casa; ( ) apartamento; ( ) outros.

Qual? Número de cômodos:

Imóvel: ( ) alugado; ( ) próprio; ( ) cedido; ( ) outros.

Qual? Número de moradores:

Quem são? ( ) pai; ( ) mãe; ( ) padrasto; ( ) madrasta; ( ) companheira;

( ) irmãos; ( ) outros:

Já teve problemas legais? ( ) não; ( ) sim/ocorrência; ( ) sim/processo; ( ) sim/prisão. Que instituição o encaminhou?

Quem o acompanha no primeiro atendimento? 


\begin{tabular}{|l|l|l|l|}
\hline Com quem conta em relação a: & Nome & $\begin{array}{l}\text { Telefone } \\
\text { de contato }\end{array}$ & $\begin{array}{l}\text { Grau de } \\
\text { parentesco }\end{array}$ \\
\hline Apoio financeiro & & & \\
\hline Acompanhamento no Caps ad & & & \\
\hline Atividades sociais/ lazer & & & \\
\hline
\end{tabular}

Observações sobre o relacionamento familiar:

\section{História da Doença Atual}

Entrevista realizada por:

Data:

Queixa principal:

Quais as substâncias psicoativas que usa? 


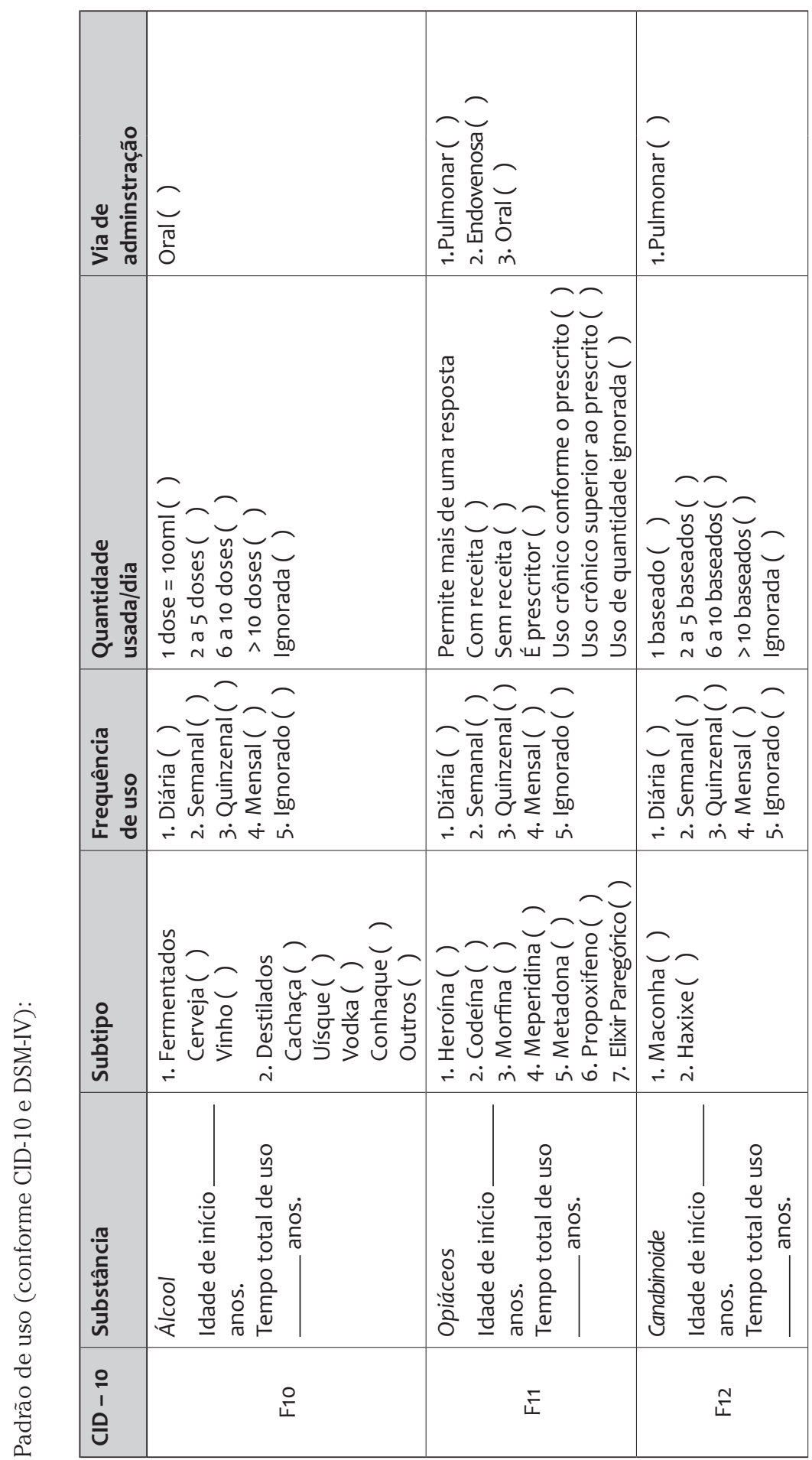




\begin{tabular}{|c|c|c|c|c|}
\hline 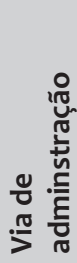 & 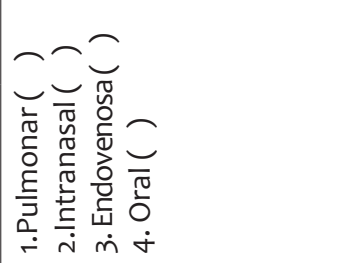 & \multicolumn{2}{|l|}{ 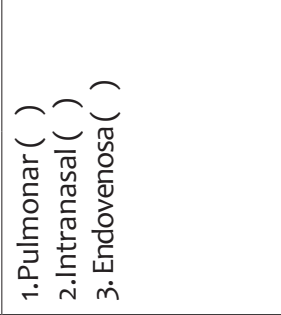 } & 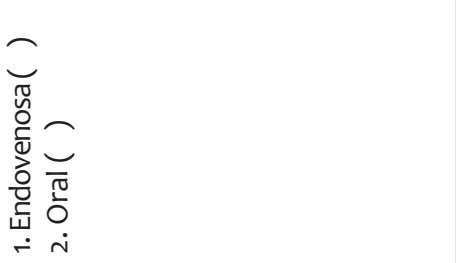 \\
\hline 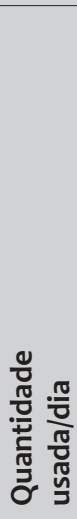 & 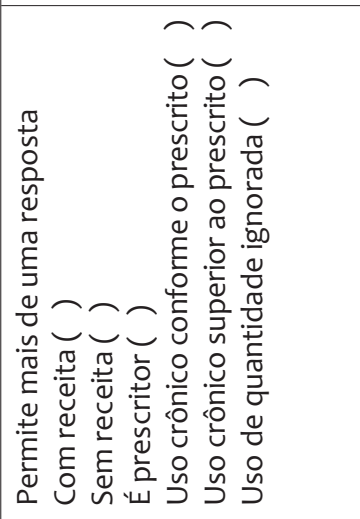 & \multicolumn{2}{|c|}{ 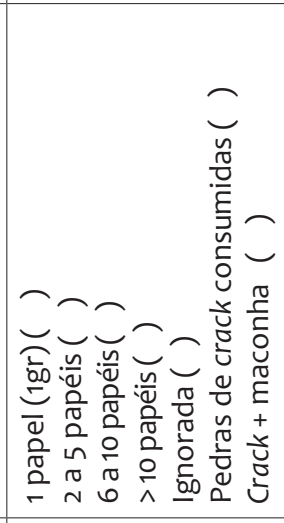 } & \\
\hline 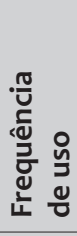 & 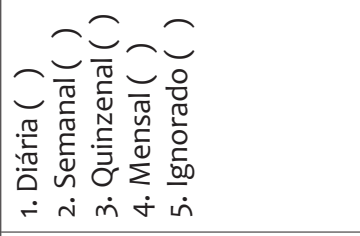 & \multicolumn{2}{|c|}{ 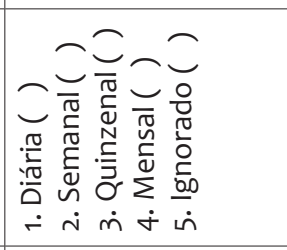 } & 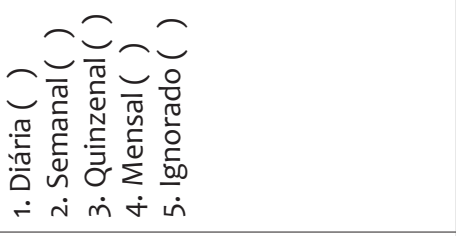 \\
\hline 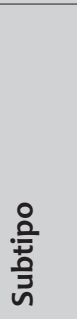 & 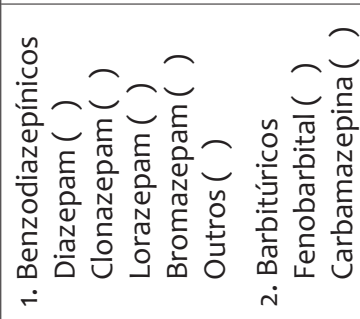 & 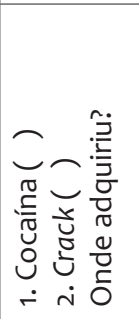 & 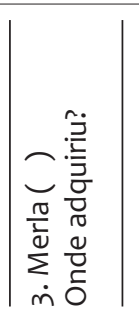 & 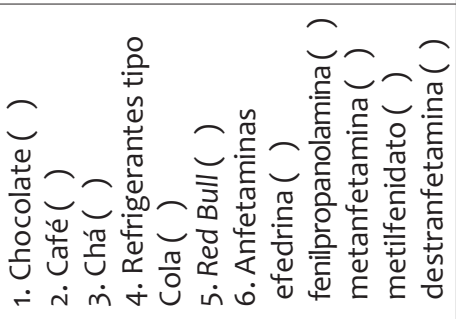 \\
\hline 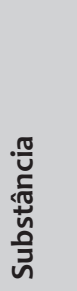 & 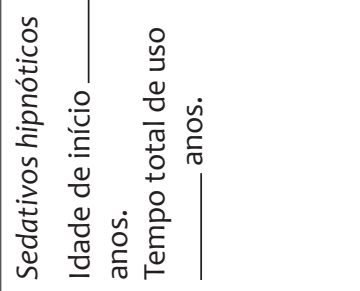 & 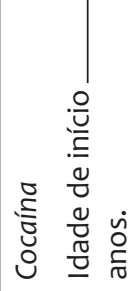 & 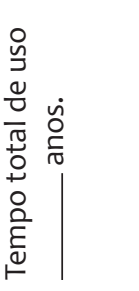 & 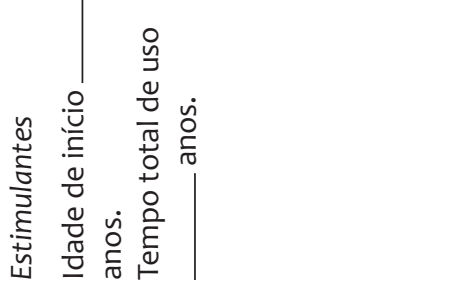 \\
\hline $\begin{array}{l}0 \\
1 \\
\varrho \\
\text { U }\end{array}$ & $\stackrel{m}{\Sigma}$ & & $\underset{\leftarrow}{ \pm}$ & $\stackrel{n}{\leftarrow}$ \\
\hline
\end{tabular}




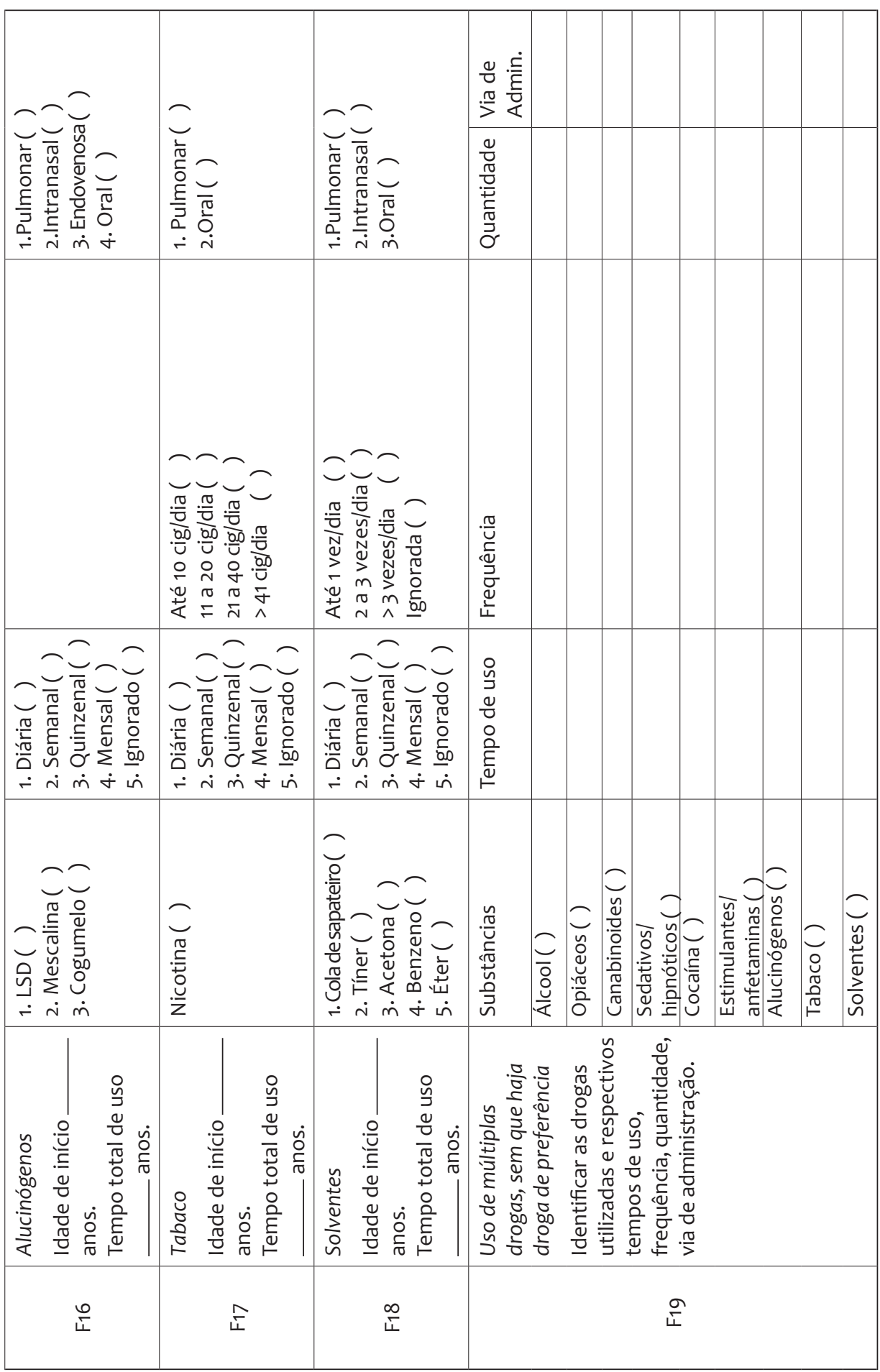


Observações: 


\section{História Patológica Pregressa}

Entrevista realizada por:

. Data:

Já se consultou com algum profissional de saúde mental? ( ) sim ( ) não.

Já fez algum tratamento para uso indevido de álcool e outras drogas? ( ) não ( ) sim.

Onde?

.Por quanto tempo?

Já participou de grupos de mútua ajuda (NA/AA)? ( ) não ( ) sim.

Há casos de uso indevido de álcool e outras drogas na família? ( ) não ( ) sim.

Já fez uso de medicamentos psiquiátricos? ( ) não ( ) sim. Quais?

Medicamentos em uso atualmente (clínicos e psiquiátricos):

Já foi internado alguma vez? ( ) não ( ) sim.

Qual (quais) foi (foram) o(s) motivo(s)?

Há quanto tempo foi a primeira internação?

Quantas internações teve até hoje?

Em quais instituições?

Há quanto tempo foi a primeira internação?

Em qual instituição foi a última internação?

Doenças comuns da infância:

Doenças alérgicas: ( ) não ( ) sim. Quais?

Alergia medicamentosa? ( ) não ( ) sim. Especificar:

Já fez transfusão de sangue? ( ) não ( ) sim.

Quando e por quê?

Já teve (ou tem) tuberculose? ( ) não; ( ) não sabe; ( ) sim.

Especificar se está em tratamento e onde:

E hepatite? ( ) não; ( ) não sabe; ( ) sim. Qual?

Especificar se está em tratamento e onde:

E hanseníase? ( ) não; ( ) não sabe; ( ) sim.

Especificar se está em tratamento e onde:

É diabético(a)? ( ) não; ( ) não sabe; ( ) sim.

Especificar se está em tratamento e onde:

Tem problemas cardíacos? ( ) não; ( ) não sabe; ( ) sim.

Especificar se está em tratamento e onde:

Tem hipertensão? ( ) sim; ( ) não; ( ) não sabe.

Doenças Sexualmente Transmissíveis (DST)? ( ) não; ( ) não sabe; ( ) sim.

Qual(quais)?

Se tem (ou já teve) alguma DST, trata (ou tratou) de que forma?

( ) orientação de um profissional de saúde; ( ) orientação de amigos; ( ) não tratou;

( ) outros: 


\section{Exame Clínico Geral}

Data de realização: Data:

Realizado por:

Sinais Vitais:

$\mathrm{T}$ :

PA:

FC:

FR:

Peso: Altura:

Data da última menstruação: (avaliação de possível gravidez).

Revisão dos sistemas:

Hipótese diagnóstica clínica (codificar e colocar por extenso de acordo com CID-10):

Exames solicitados: 


\section{Exame Físico}

Data: Examinador:

\section{Aspecto Geral:}

( ) normocorado

( ) hidratado

( ) dispneico

( ) hipocorado

( ) desidratado

( ) eupneico

Higiene satisfatória: ( ) sim ( ) não.

Observações:

\section{2. Órgãos e sistemas:}

\subsection{Pele}

Lesões/Manchas: ( ) acrômica; ( ) hipercrômica; ( ) hipocrômica

Sensibilidade: ( ) dolorosa; ( ) tátil; ( ) térmica.

Lesões: ( ) vesícula; ( ) bolha; ( ) pústula; ( ) abscessos; ( ) erosão; ( ) fissura; ( ) fístula; ( ) úlcera.

\subsection{Crânio}

( ) Retração ( ) Abaulamento.

\subsection{Olhos}

Especificar alterações:

\subsection{Nariz}

Especificar alterações:

\subsection{Orelhas}

Especificar alterações:

\subsection{Cavidade oral}

Especificar alterações:

\subsection{Pescoço}

Nódulos palpáveis? ( ) sim ( ) não.

\subsection{Tórax}

Especificar alterações:

Ausculta pulmonar: ( ) MVUA; ( ) estertores; ( ) roncos; ( ) sibilos.

\subsection{MMII}

Presença de edema? ( ) sim ( ) não.

Especificar alterações: 
340 Álcool e Outras Drogas: dí́logos sobre um mal-estar contemporâneo

\section{Eliminações}

\subsection{Vesicais}

( ) realizadas normalmente; ( ) realizadas com dificuldade.

\subsection{Intestinais}

( ) realizadas normalmente; ( ) realizadas com dificuldade; ( ) presença de sangue. Consistência:

Cor:

Aspecto:

\subsection{Vômitos}

Frequência:

Presença de sangue? ( ) sim ( ) não.

\section{Antecedentes familiares}

( ) diabetes

( ) hipertensão

( ) doença cardíaca

( ) transtorno mental
( ) doenças autoimunes

( ) tuberculose

( ) outros: 


\section{Exame Psíquico}

Data: /__ Examinador:

\section{Niveis de consciência/orientação}

Lúcido: ( ) consciente/orientado no tempo e no espaço;

( ) desorientado no tempo e no espaço.

Confuso: ( ) orientado no tempo e no espaço; ( ) desorientado no tempo e no espaço. Apresenta história de: ( ) desmaios; ( ) convulsões; ( ) quedas.

Observações:

\section{Atenção}
( ) hipoprosexia
( ) hipertenacidade/ hipovigilância
( ) hipervigilância/hipotenacidade
( ) sem alteração

Observações:

\section{Memória}
( ) amnésia anterógrada
( ) alucinações mnêmicas
( ) amnésia retrógrada
( ) déficit na memória de fixação
( ) fabulações
( ) sem alteração

Observações:

\section{Sensopercepção}

( ) hiperestesia; ( ) hipoestesia; ( ) alucinações; ( ) sem alteração.

Observações:

\section{Pensamento}

( ) aceleração do pensamento

( ) lentificação do pensamento

( ) roubo do pensamento

( ) fuga de ideias

( ) ideias obsessivas

( ) prolixidade

( ) perseveração

( ) concretismo

( ) delírios

( ) sem alteração

Observações:

\section{Linguagem}

( ) logorreia/taquifasia; ( ) bradifasia; ( ) resistência à comunicação verbal;

( ) sem comunicação verbal; ( ) sem alteração.

Observações: 


\section{Inteligência}

Investigar desenvolvimento intelectivo deficiente (retardo mental) ou deterioração intelectiva (demência):

\section{Afetividade}
( ) humor ansioso
( ) humor maníaco
( ) humor irritado
( ) sem alteração

( ) humor deprimido

Observações:

\section{Vontade}
( ) atos impulsivos
( ) atos suicidas
( ) atos compulsivos
( ) sem alteração
( ) automutilações

Observações:

\section{Psicomotricidade}
( ) agitação psicomotora, hostilidade
( ) conversão motora
e heteroagressão
( ) alteração da marcha/movimentos
( ) lentificação psicomotora
( ) sem alteração
( ) estereotipias motoras

Observações:

\section{Pragmatismo/interações sociais}

( ) dificuldade em realizar atividades domésticas convencionais

( ) falta de asseio corporal

( ) dificuldade para atividades profissionais

( ) falta de interesse por atividades cotidianas

( ) dificuldade em assumir compromissos/ concluir atividades

( ) retraimento social

( ) isolamento social

( ) sem alteração

Observações:

\section{Sono e repouso}

( ) dificuldade de adormecer

( ) acorda várias vezes à noite

( ) pesadelos

( ) sonolência durante o dia

( ) fadiga ao despertar

( ) dorme durante o dia

( ) terrores noturnos

( ) sem alteração

Observações: 


\section{Áreas de Interesses e Habilidades}

Entrevista realizada por:

Data:

Sabe ler e escrever? ( ) sim ( ) não. Gostaria de aprender?

Já desenvolveu, ao longo de sua vida, atividades relacionadas à música?

( ) não ( ) sim. Quais?

Apresenta interesse em participar de atividades relacionadas à música durante a permanência no Caps ad? ( ) não ( ) sim.

Qual(is) o(s) estilo(s) musical(is) de sua preferência?

Gosta de contar histórias? ( ) sim ( ) não.

Tem conhecimentos sobre informática? ( ) sim ( ) não.

Interessa-se em obtê-los?

Já trabalhou (ou tem interesse em trabalhar) em atividades comerciais?

( ) não ( ) sim. Quais?

Já praticou (ou pratica) algum esporte?

( ) não ( ) sim. Quais?

Já desenvolveu, ao longo de sua vida, atividades relacionadas ao teatro?

( ) não ( ) sim. Quais?

Já desenvolveu, ao longo de sua vida, atividades relacionadas ao artesanato?

( ) não ( ) sim. Quais?

Dentre as atividades abaixo, qual(quais) desperta(m) seu interesse?

( ) argila

( ) reciclagem

( ) pintura em tecido

( ) bordado

( ) mosaico
( ) embalagem

( ) papel maché

( ) velas

( ) cartonagem

( ) pintura em tela
( ) origami

( ) produção de instrumentos musicais

( ) outras:

Há alguma atividade que gostaria muito de aprender? ( ) não ( ) sim.Qual? Quais os dias e os horários disponíveis para aprender tal(tais) atividade(s)?

\begin{tabular}{|l|l|l|l|l|l|}
\hline & Segunda-feira & Terça-feira & Quarta-feira & Quinta-feira & Sexta-feira \\
\hline Manhã & & & & & \\
\hline Tarde & & & & & \\
\hline Noite & & & & & \\
\hline
\end{tabular}

Há alguma atividade que poderia ensinar? ( ) não ( ) sim. Qual?

Quais os dias e os horários disponíveis para ensinar tal(tais) atividade(s)?

\begin{tabular}{|l|l|l|l|l|l|}
\hline & Segunda-feira & Terça-feira & Quarta-feira & Quinta-feira & Sexta-feira \\
\hline Manhã & & & & & \\
\hline Tarde & & & & & \\
\hline Noite & & & & & \\
\hline
\end{tabular}




\section{História Sexual}

Entrevista realizada por:

Data:

1

Já teve relações sexuais? ( ) sim ( ) não.

Com quantos anos você teve a primeira relação sexual? anos.

Você já engravidou (ou engravidou alguém)? ( ) não ( ) sim.

Qual a sua idade na primeira gravidez? anos.

Atualmente está namorando? ( ) sim ( ) não.

Considerando seu relacionamento atual:

( ) parceiro fixo único morando junto ( ) parceiro fixo único não morando junto

( ) parceiro fixo único não exclusivo ( ) parceiros ocasionais

Qual a idade do seu parceiro atual? anos.

Usou preservativo na primeira relação sexual? ( ) sim ( ) não.

Qual? ( ) feminino ( ) masculino. Motivo:

Utilizou na sua primeira relação sexual algum outro método contraceptivo?

( ) não ( ) sim. Qual?

Já usou alguma vez o preservativo masculino? ( ) sim ( ) não.

Já usou alguma vez o preservativo feminino? ( ) sim ( ) não.

Em média, quantas relações tem por mês?

Nas suas relações sexuais, você usa preservativo:

( ) nunca; ( ) algumas vezes; ( ) sempre.

Justificativa para tal frequência:

Quando foi a última vez que teve relação sexual?

Usou preservativo?

( ) sim. Qual?

( ) não, porque não tinha

( ) não, porque não deu tempo

( ) não, porque não quis

( ) não, porque o parceiro não quis

( ) não, porque esqueceu

( ) não, porque a camisinha arrebentou e não tinha outra

( ) outro motivo:

Já fez teste anti-HIV? ( ) sim ( ) não. Por quê?

Sabe o que é uma DST? ( ) sim ( ) não.

Se sabe, poderia citar três sintomas de DST? ( ) não ( ) sim.

Quais?

Saberia citar algum método contraceptivo? ( ) não ( ) sim. Qual?

Para uso exclusivo do entrevistador:

Número de camisinhas distribuídas:

Data:

1

Entrevistador: Data: 


\section{Hipóteses Diagnósticas}

(codificar e colocar por extenso de acordo com CID-10)

Observações

Condutas e Observações 
346 Álcool e Outras Drogas: dí́logos sobre um mal-estar contemporâneo

\section{Referências}

DALGAlARRONDO, P. Piscopatologia e Semiologia dos Transtornos Mentais. Porto Alegre:Artmed, 2000.

DSM-IV. Manual Diagnóstico e Estatístico de Transtornos Mentais. Porto Alegre: Artes Médicas, 1995.

ORGANIZAÇÃO MUNDIAL DA SAÚDE (OMS). Classificação Estatística Internacional de Doenças - CID 10.10ª ed. São Paulo: Editora USP, 1999. 
Formato: $16 \times 23 \mathrm{~cm}$

Tipologia: ITC Chelteham Std

Papel: Polén bold $70 \mathrm{~g} / \mathrm{m}^{2}$ (miolo)

Cartão supremo $250 \mathrm{~g} / \mathrm{m}^{2}$ (capa)

CTP, impressão e acabamento: Imo's Gráfica e Editora Ltda.

Rio de Janeiro, maio de 2012.

Não encontrando nossos títulos em livrarias, contactar:

Editora Fiocruz

Av. Brasil, 4036 - térreo - sala 112 - Manguinhos

CEP 21040-361 - Rio de Janeiro - RJ.

Tel.: (21) 3882-9039 e 3882-9041 - Telefax: (21) 3882-9006

editora@fiocruz.br I www.fiocruz.br/editora 